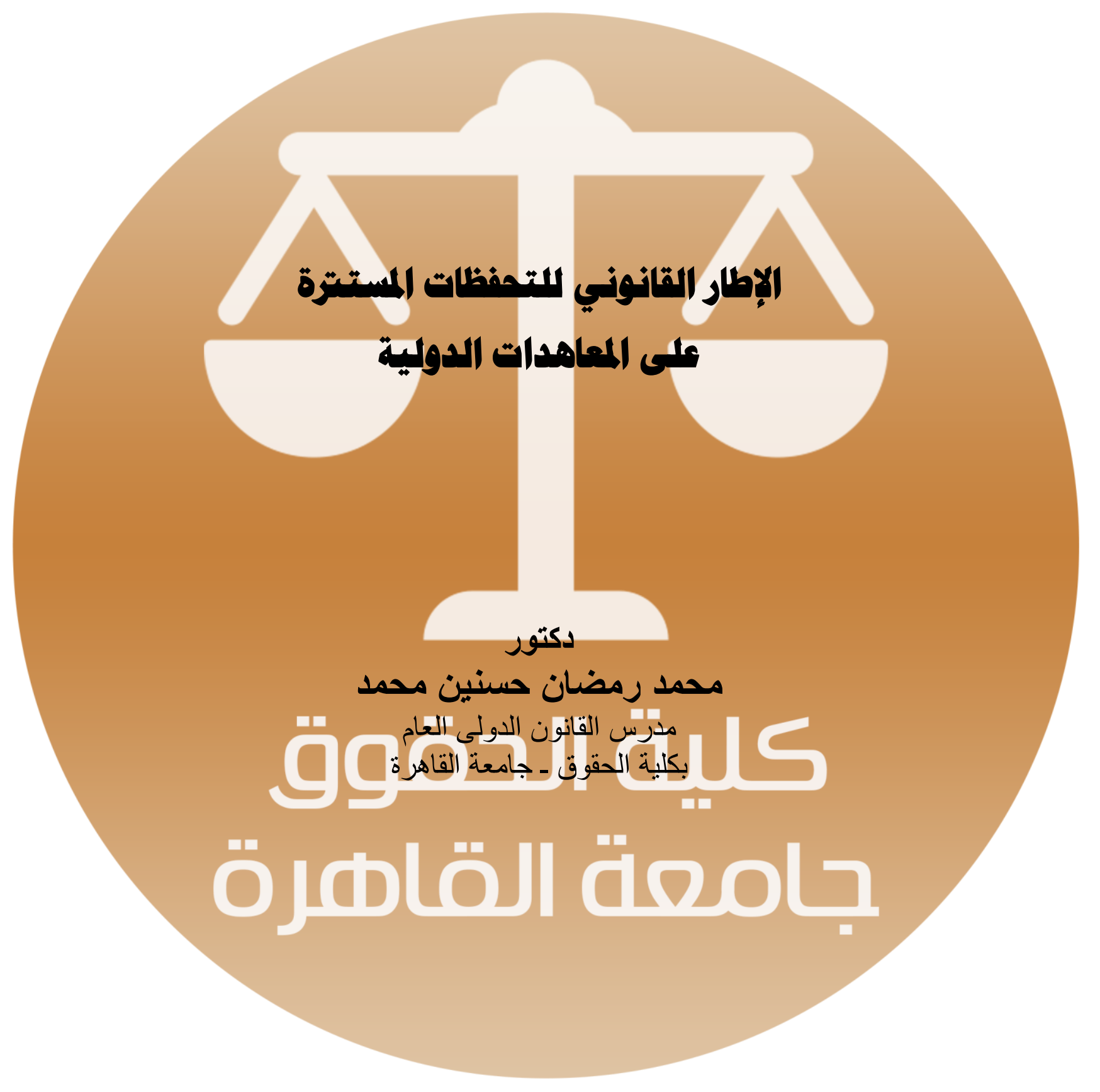




\section{فطة البمث}

مقدمة

الفصل الأول: التحفظات علي المعاهدات الدولية

المبحث الأول: ماهية التحفظات في القانون الدولي العام وأسبابها.

المبحث الثاني: أنواع التحفظات علي المعاهدات الدولية.

الفصل الثاني :- التفرقة بين التحفظات المستترة والإعلانات التفسيرية

المبحث الأول: ماهية التحفظات المستترة على المعاهدات الدولية.

المبحث الثاني : موقف الفقه الدولي من التحفظات المستترة

بين التحفظات المستترة والإعلانات

المبحث الثالث: إثكالية التفرقة بيرة

$$
\text { التفسيرية. }
$$

الفصل الثالث: التطبيقات المنتلفة للتحفظات المسترة

المبحث الاول : المعايير واجبة التطبيق للتثرقة بين التحفظات المستترة

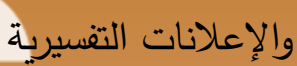

المبحث الثاني : تحليل قانوني لتطبيقات مختلفة للتحفظات المستترة

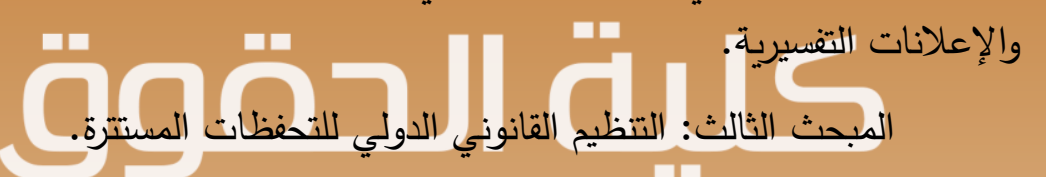

خاتمة 


\section{مقدهة}

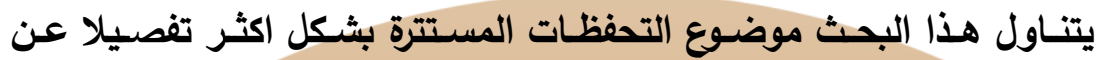

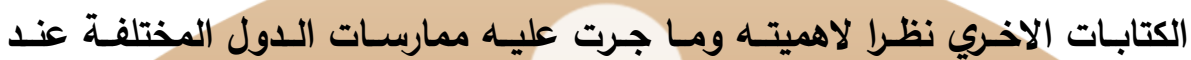

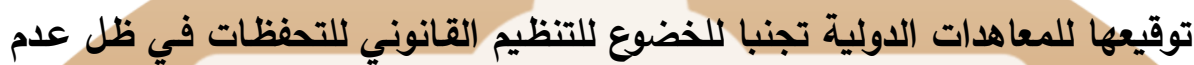

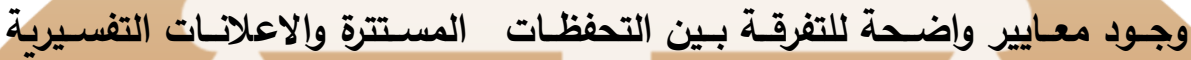

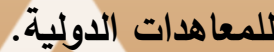

و لم يلق موضوع التحفظات المستترة عناية بالغة من الفقه الدولي، اذ يندر

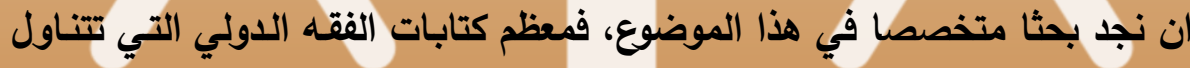

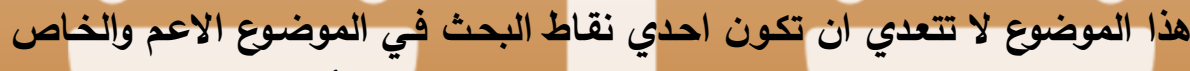

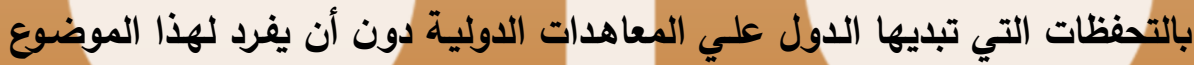

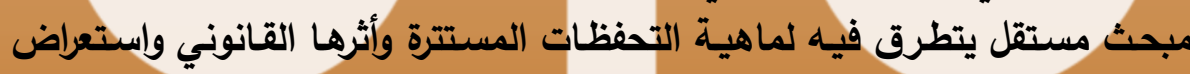
التنظيم القانوني للتحفظات المستترة والتفرقة بينها وبين الإعلانات التفسيرية.

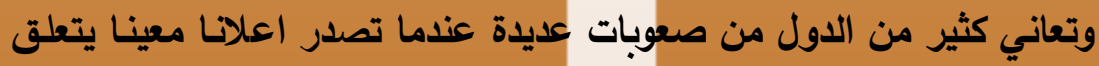

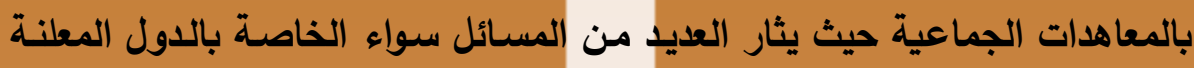

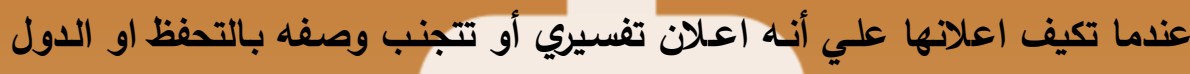

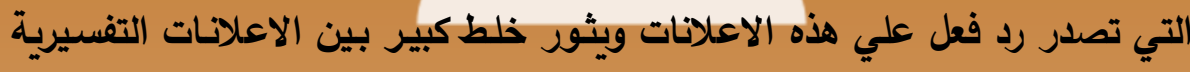

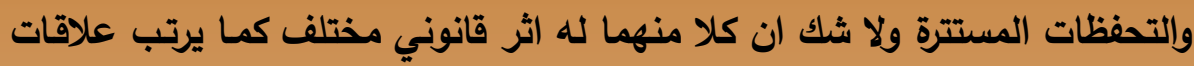

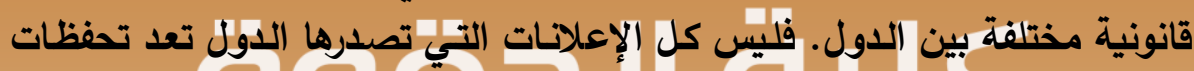

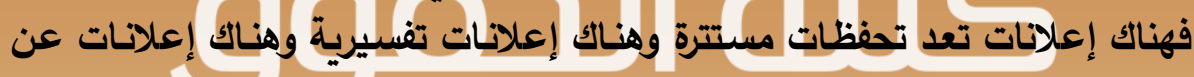

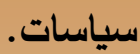

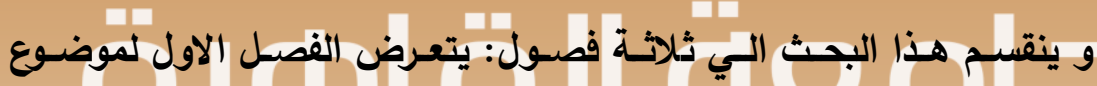

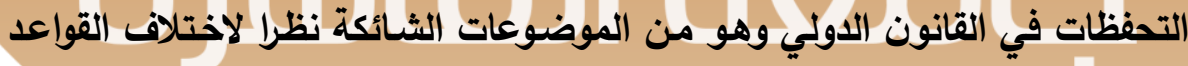

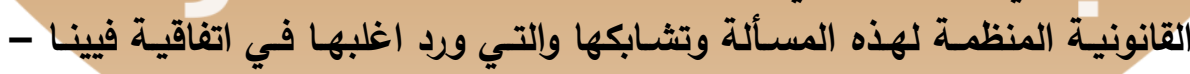

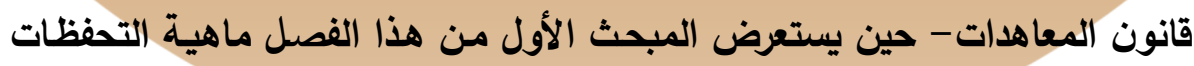

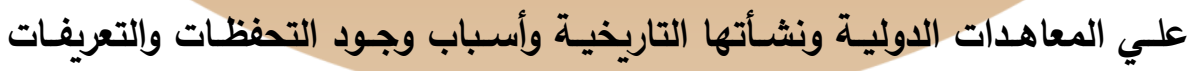

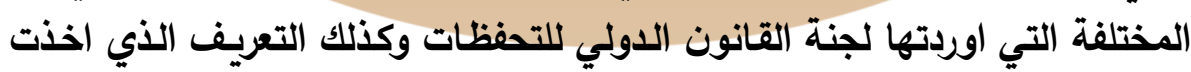


بـاه اتفاقيـة فيينـا أمـا المبحث الثاني فيتعرض لانـواع التحفظـات علـي المعاهدات

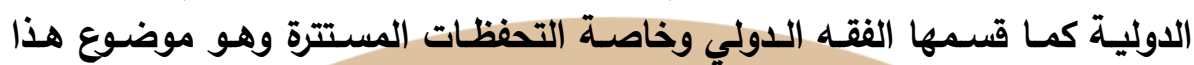
البحث.

أمـا الفصـل الثـاني فيعرض موقـف الفقـهـ الــولي المعاصـر مـن التحفظـات

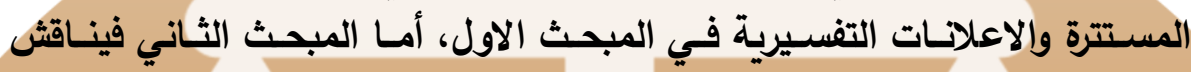

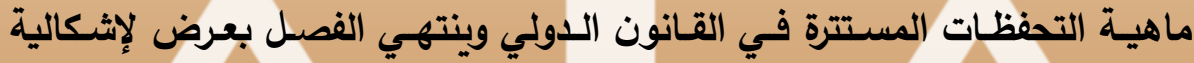

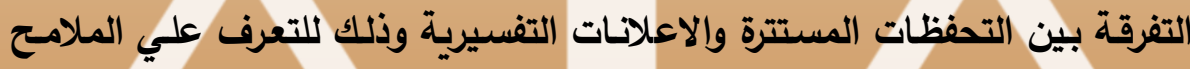
الرئيسية للتحفظات المستترة في المبعث الثالث. امـا الفصـل الثالث فيعرض لاهـم مجـالات البحث حيث يتعرض بالتفصيل

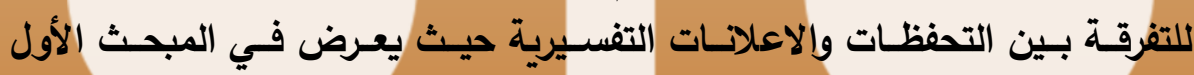

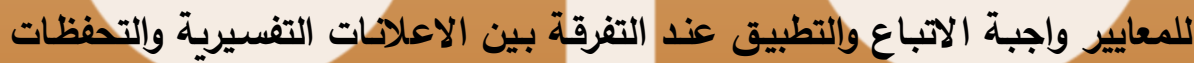

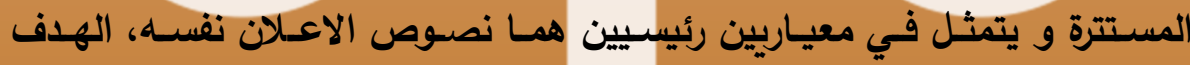

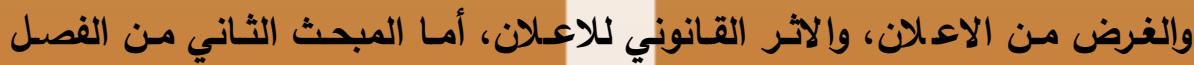

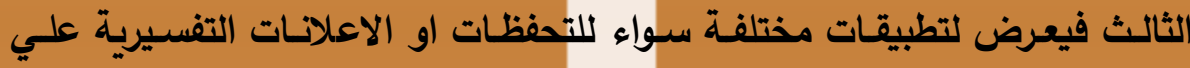

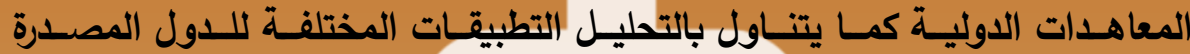

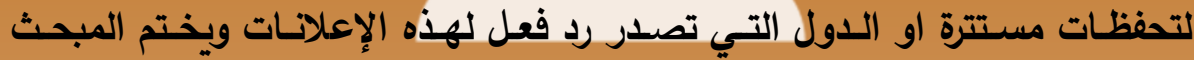

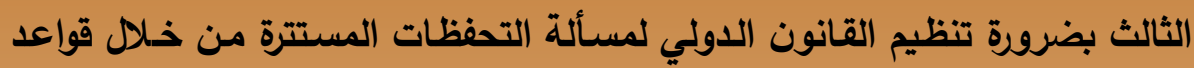

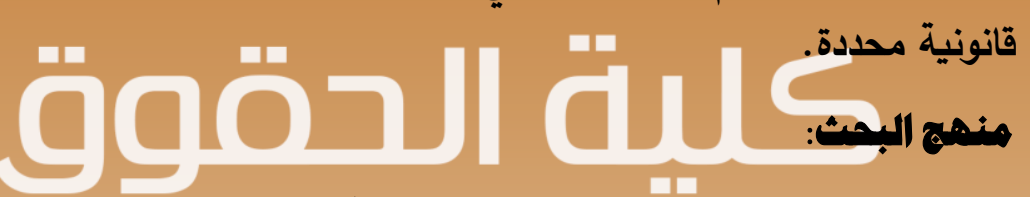

سيتم إتباع المنهج التحليلي والتطبيقي في هذا البحث للعديد من التحفظات

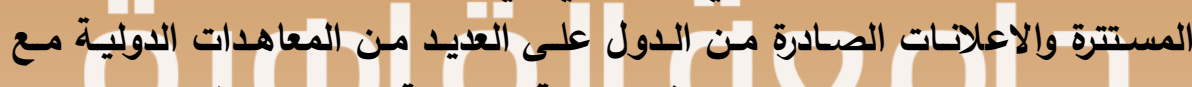

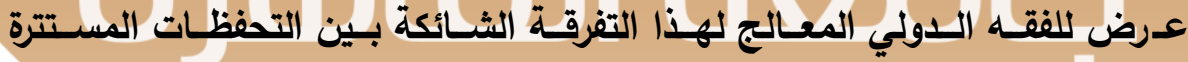
والإعلانات على المعاهدات الدولية للوقوف على اتجاهات الفقه الدولي الذي ماتي زال

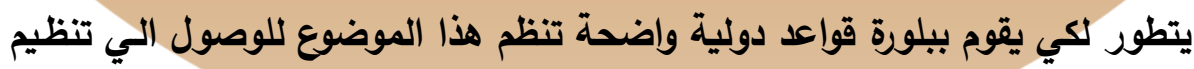
قانوني دولي متكامل للتحفظات المستترة. 
أهمية البمث ونطاقه:

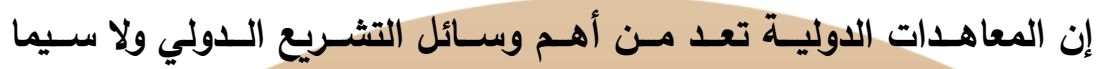

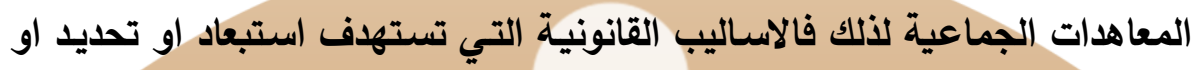

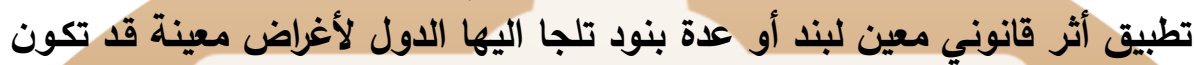

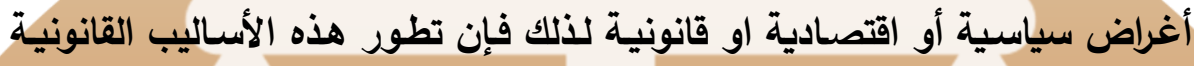

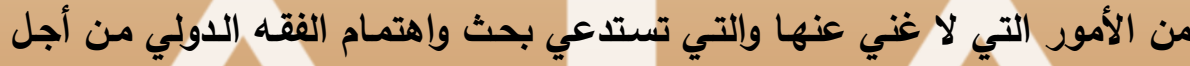
الوصول الي تنظيم دولي واضح للتحفظات المستترة التي تصدرها الدول.

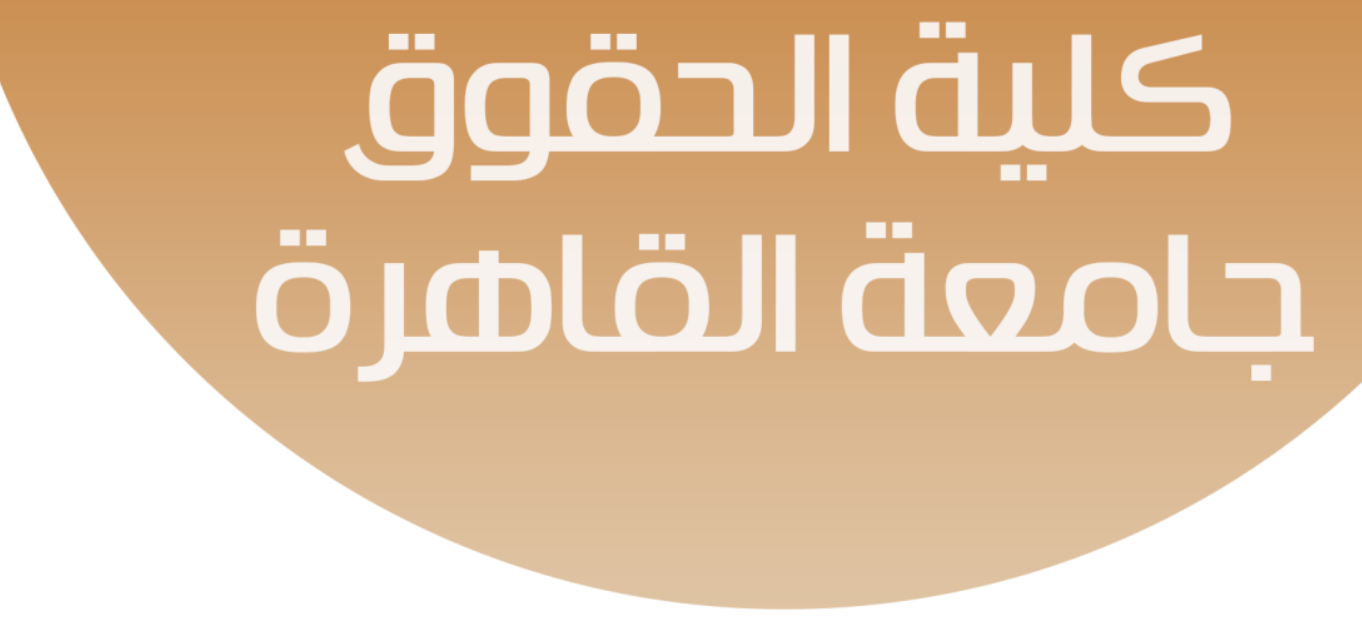




\section{النصل الأول}

\section{التمنظات ملى الإعاهدات الدوولية}

إن التحفظات من الموضدوعات التي تناولها الفقـه الدولي منذ بدايات القرن

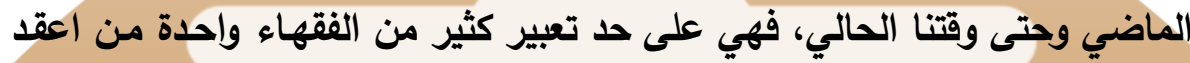

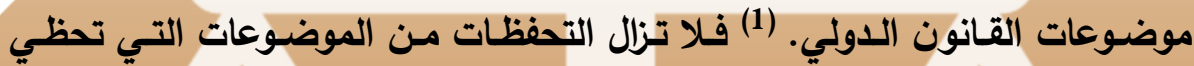

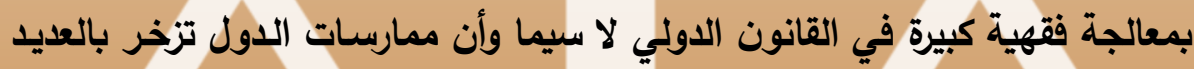

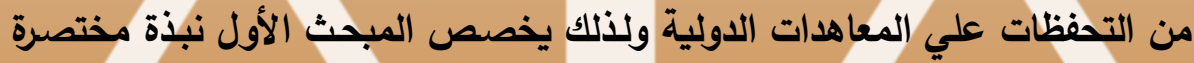

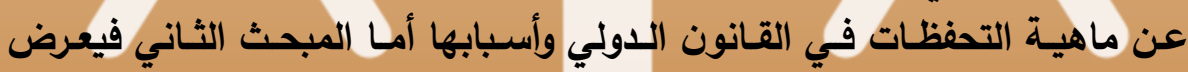

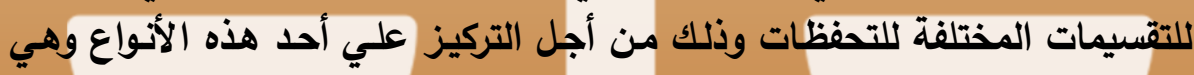
التحفظات المستترة التي تثكل موضوع هذه الدراسة.

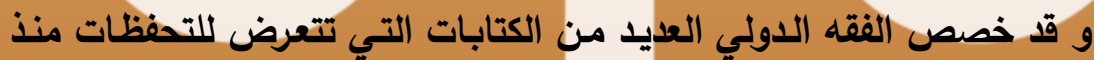

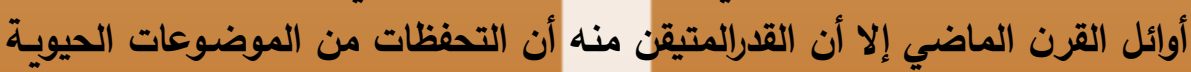

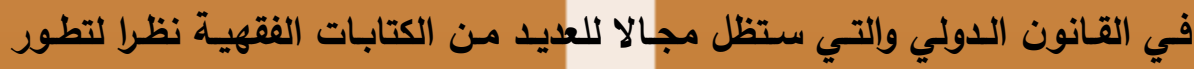

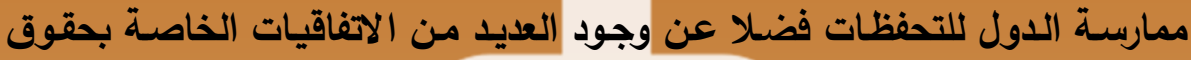

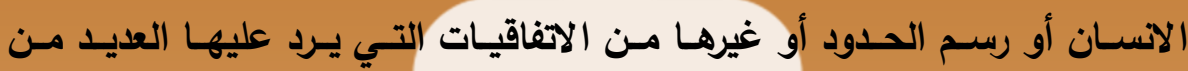

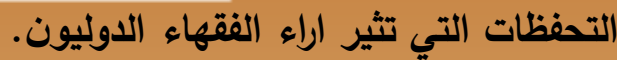

ومن خلال هذا البحث سنعرض للمناقشات العديدة حول التحفظات وأنواعها

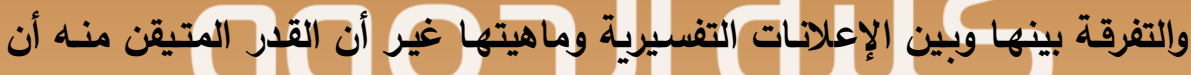

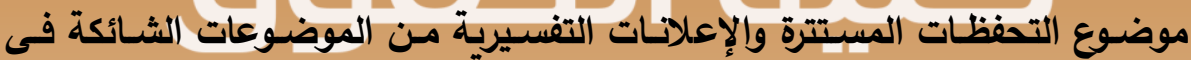
كتابات القانون الدولى العام. فهي من المهام الشاقة لفقهاء القانون الدولئي. 2

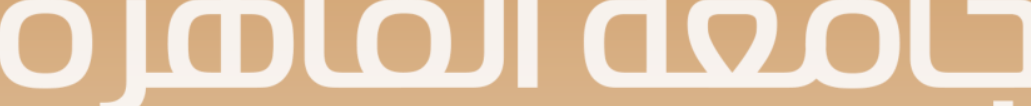

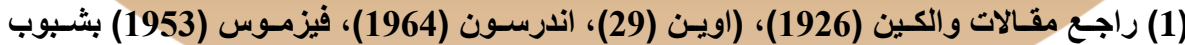

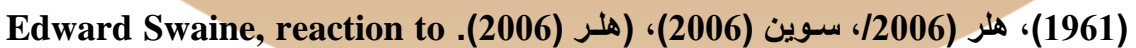

his article in Lawrence Hefler, Not fully committed? Reservations, risk and treaty design, 31 Yale J. Int'l L. 367 (2006).

)2( G.C. Fitzmaurice, Reservations to multilateral conventions, op. cit., p. 1. 


\section{المبمث الاول}

\section{ماهية التمنظات على المعاهدات الدولية وأسبابها}

لقي موضوع التحفظات اهتماما واسعا من العديد من فقهاء القانون الدولي

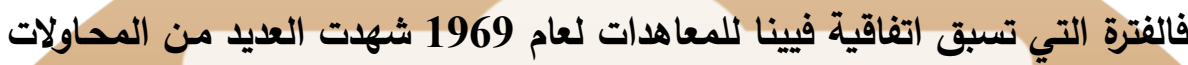

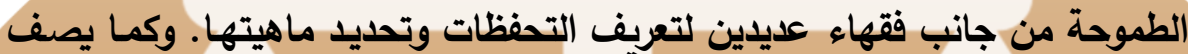

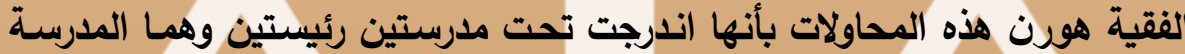

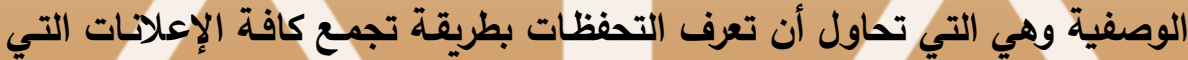

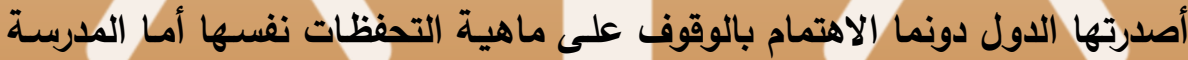

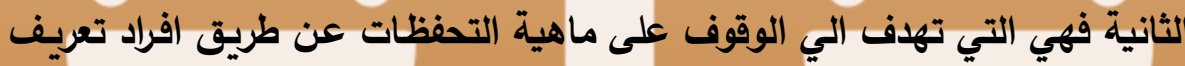
محدد ومستقل للتحفظات.

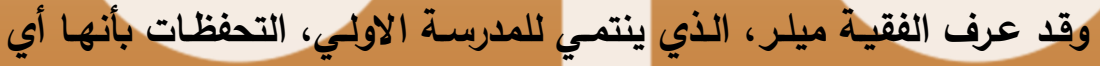

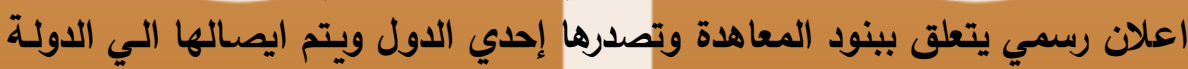
الأخرى عند أو قبل تبادل وثائق التصديق على المعاهدة. أما مسودة هارفارد لقانون المعاهدات فقد عرفت التحفظات بأنها إعلانات

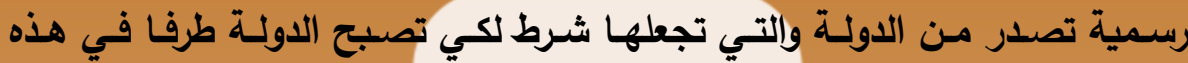

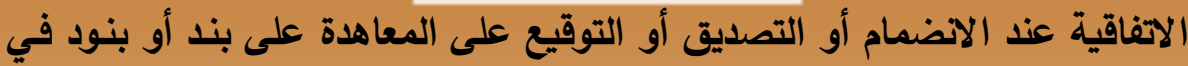

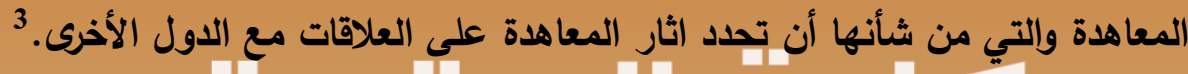

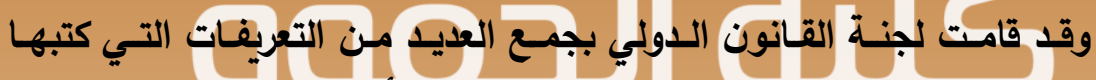

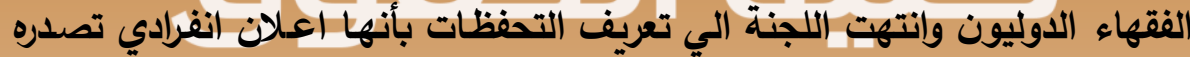

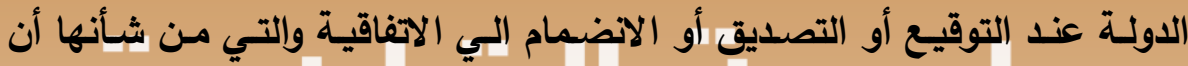
تؤدي الي استبعاد أو تغيير الأثز القانوني لبعض الانفي البنود الواردة في الاتفاقية.

(1) Frank Horn, Reservations and interpretative declarations to multilateral treaties, op. cit.; p. 33-34

(2) Id. at p. 34

(3) Id. at p. 35

(4) Id. 
وقد جري بعد ذلك تعديل بسيط على هذا التعريف بأن اضيف اليها "مهمـا

كانت تسميته أو صياغته" الي التعريف الذي جاءت بـه لجني لجنة القانون الدولي.

وقامت إتفاقية فيينا للمعاهدات بتعريف التحفظات بأنها " إعلان من جانب أبـات

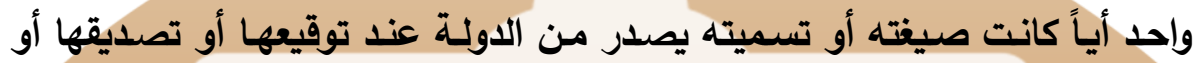
قبولها أوموافقتها أو إنضمامها إلى معاهدة وتهدف بـه إلى إستبعاد أو تعديل الأثر

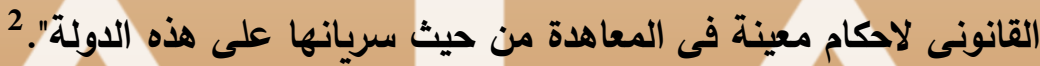
وقد انتقد الفقيه برونلي Brownlie تعريف اتفاقية فيينا للتحفظات واسباغ صفة الانفرادية على التحفظات حيث رأي في ذلك اعتراضل على الطبيعة التعاقدية

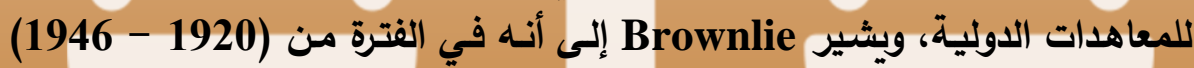

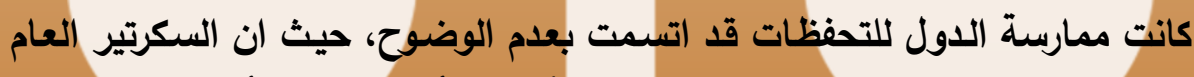

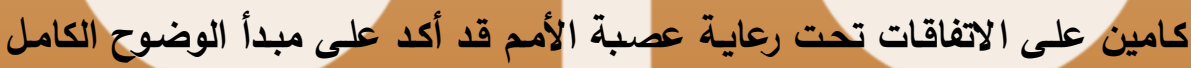

\section{3 .absolute integrity للاتفاقيات} (أمة تارئية عن التمفنات:

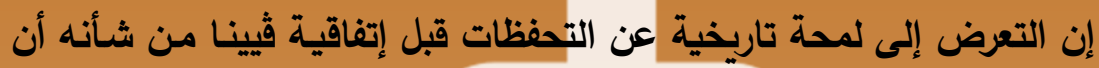

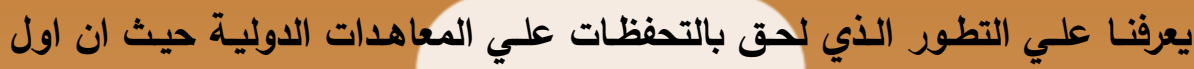

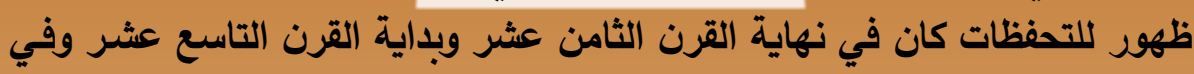

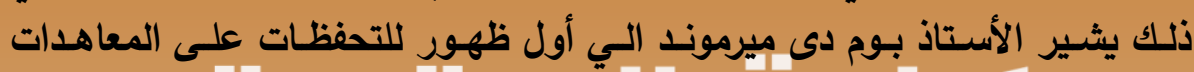

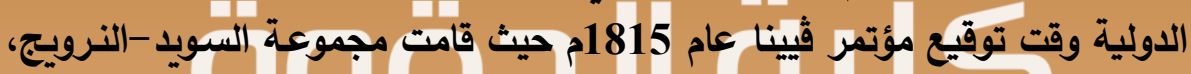

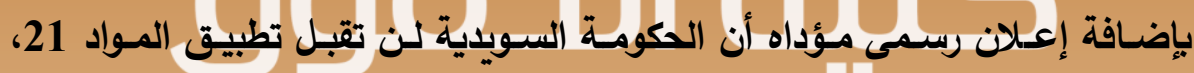

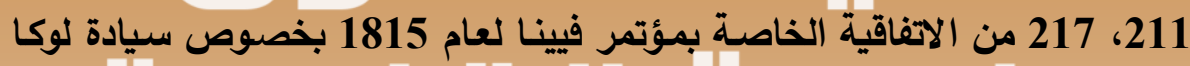

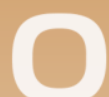

(1) Id. at p. 38

(2) Article (2)(d) of the Vienna Convention on the law of treaties, United Nations Treaty Collection, http://treaties.un.org/Pages/ViewDetailsIII.aspx?\&src=TREATY\&mtds g no=XXIII 1\&chapter $=23 \&$ Temp $=$ mtdsg $3 \&$ lang $=$ en

(3) I. Brownlie, Principles of internaitonal law, Oxford University Press, p. 613 (2004). 
والاعتراف بفرديناند الرابع ملك جزيرتى سيلى.1

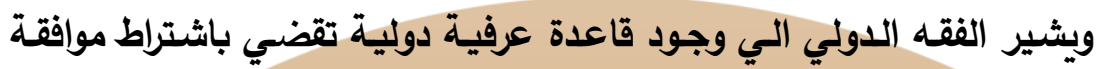

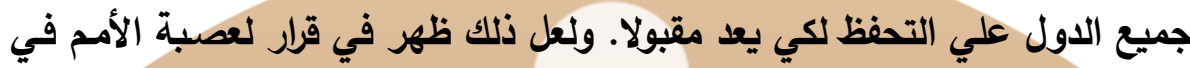

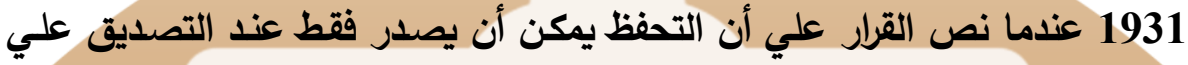

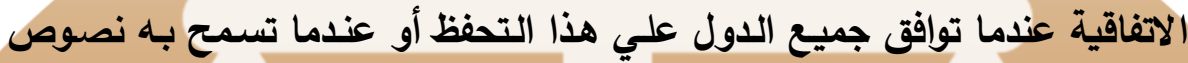

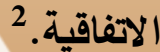

وقد قام الفقيه Waldock بتعريف التحفظات في أول تقرير لـه قدم إلى في التى

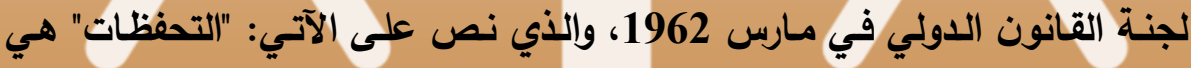

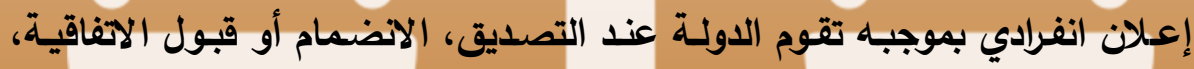

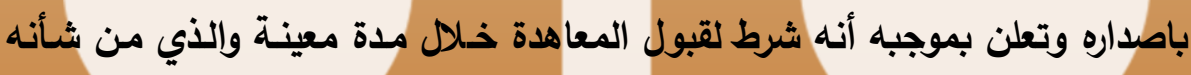

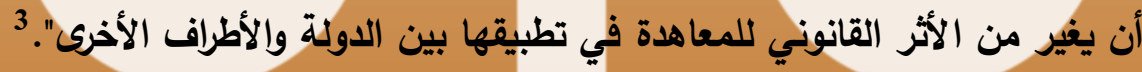

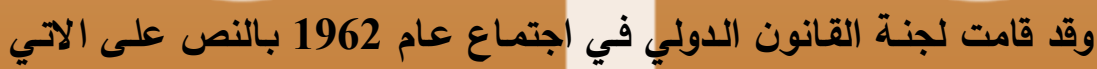

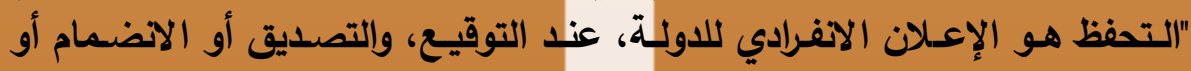

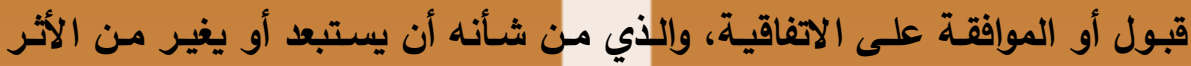

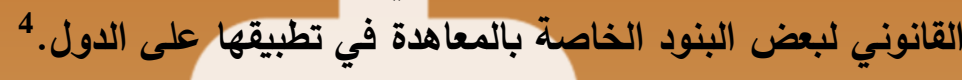

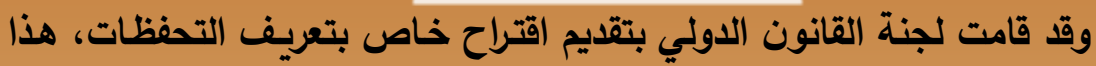

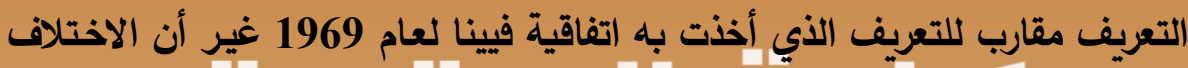

(1) See Bishop, Reservations to treaties, op. cit., at 261-62, see also John king Gamble, Reservations to multilateral treaties: A macroscopic view of state practice, 74 Am. J. Int'l L. 376 (1980), See also D.R. Anderson, Reservations to multilateral conventions:a reexamination, 13 Int'l \& Comp. L.Q. 454 (1964). See also, Frank Horn, Reservations and interpretative declarations to multilateral treaties, op. cit.; p. 7.

(2) Jean Kyongun Koh, Reservations to Multilateral Treaties: How International Legal Doctinr reflects World vision, Harvard Int' Law Journal, Vol. 23, p. 77

(3) Waldock, First report on the law of treaties (1962).

(4) 1962 ILC Report p. 161-Article 1(1)(f) of draft articles on the law of treaties. 


\section{الوحيد هو حذف كلمة "أيا كان تسميته أو صياغته". 1}

وقد قامت منظمـة الدول الأمريكية بانتهاج نظام مرن خاص يسمح للدولة

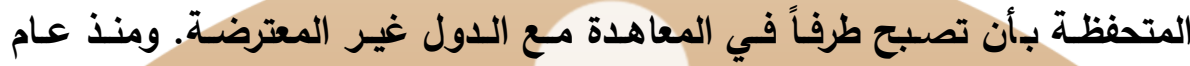

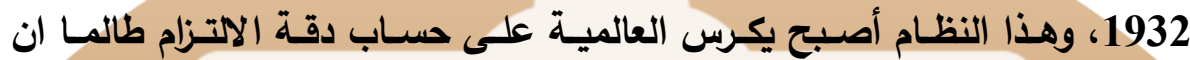

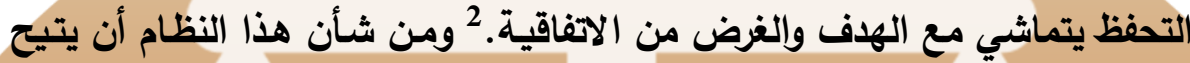

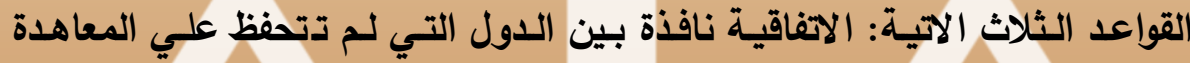

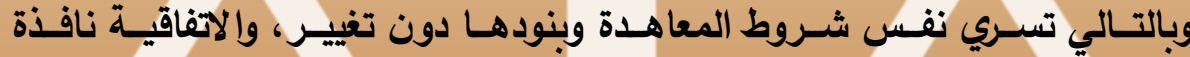

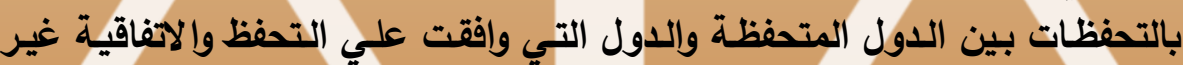
نافذة بين الدول المتحفظة والدول التي لم توافق علي التحفظة التئ. ويشير Brownlie إلى اختلاف الآراء بين الدول حول التحفظات وذلك بعد

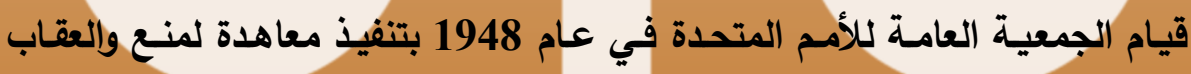
(1) بعد الحرب العالمية الثانية قامت الجمعية العامـة للامـم المتحـدة بتوجيـه طلب الـي لجنـة القانون

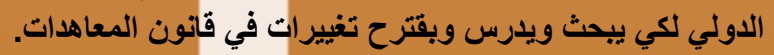

For the text of the definition of "reservation" proposed by the international law commission, see Article (2)(1)(d) of the draft articles on the law of treaties with commentaries, adcopted by the General Assembly on the work of its 18th session, 21 U.N. GAOR Supp. (No. 9) at 21 , UN Doc. $A / 6309 /$ Rev. (1966) reprinted in (1966) 2 Y.B. Int' $L$ L. Comm. 172, 178, UN Doc. A/CN 4/SER.A/1966/Add. 1 and om 19681969 Vienna conference documents, commentary to Art. I(1)(F) of draft articles on the law of treaties, report of the international law commission to the General assembly covering the 14th session.

(2) Daniel Hylton, Default breakdown: The Vienna convention on the law of treaties' inadequate framework on reservations, 27 Vand. J. Transnat'l L. 424 (1994)-ICJ report (1951), 15 at 21, 24. "A state...which has made a reservation which has been objected to by one "more of the parties to the convention but not by others, can be regarded as being a party to the convention if the reservation is compatible with the object and purpose of the convention."

(3) Jean Kyongun Koh, Reservations to Multilateral Treaties: How International Legal Doctinr reflects World vision, Harvard Int' Law Journal, Vol. 23, p. 80 
على جريمة الإبادة العنصرية والتي لم تتعرض لهذا الموضوع.1

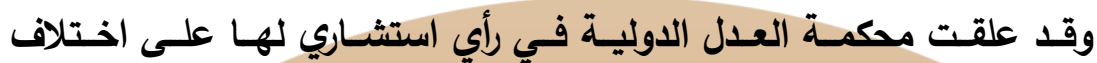

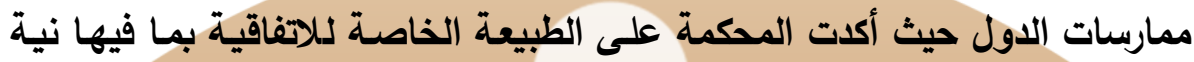

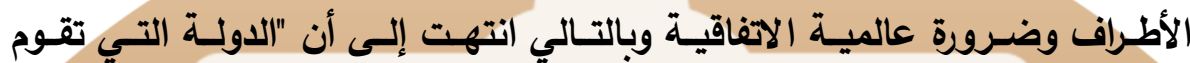

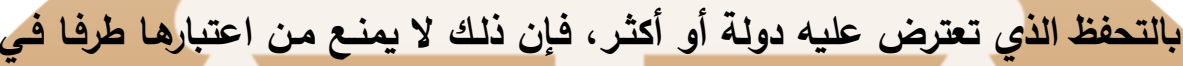

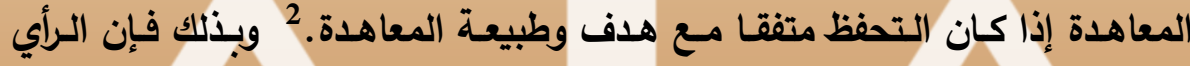

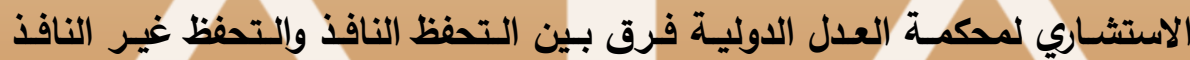

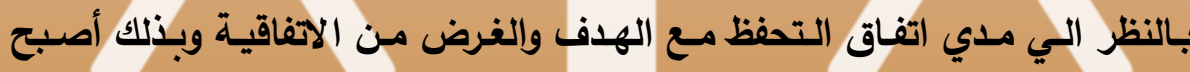

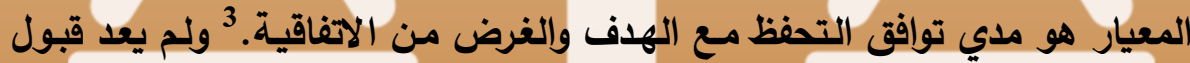
التحفظ من جاتب جميع الدول شرطا لنفاذ التحفظ. (ب) التمنظات على المعاهد|ت الثنانية:

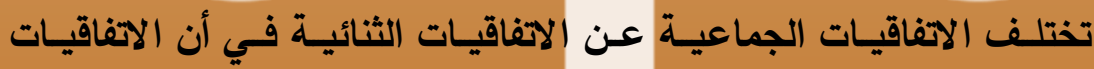

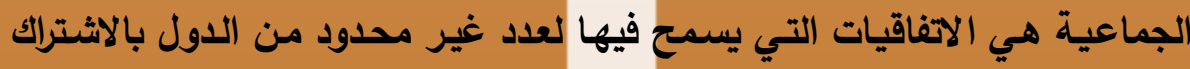

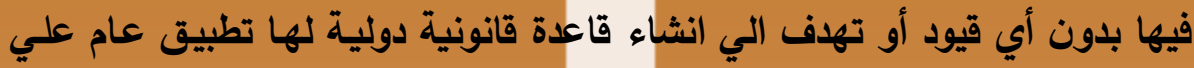

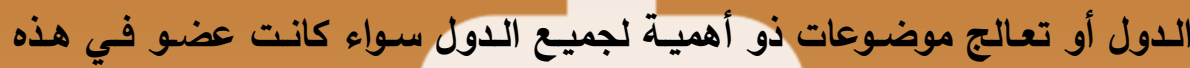

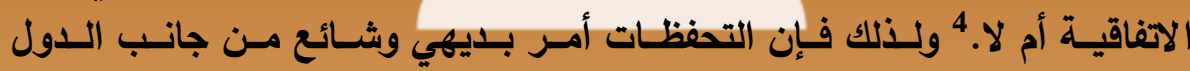

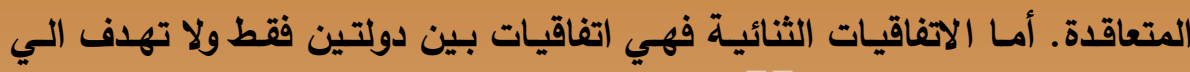

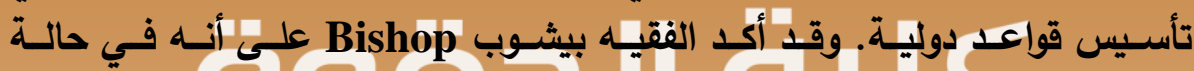

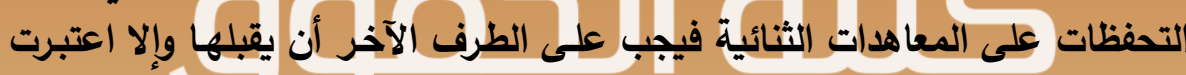

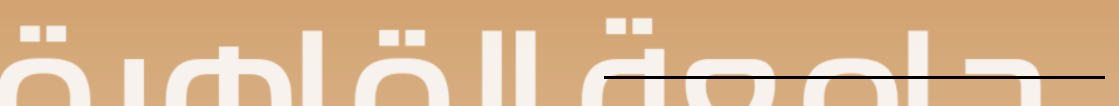

(1) Ian Brownlie, Principles of international law, op. cit., p. 613

(2) Loc. Cit.

(3) Jean Kyongun Koh, Reservations to Multilateral Treaties: How International Legal Doctinr reflects World vision, Harvard Int' Law Journal, Vol. 23, p. 85

(4) Jean Kyongun Koh, Reservations to Multilateral Treaties: How International Legal Doctinr reflects World vision, Harvard Int' Law Journal, Vol. 23, p.89 


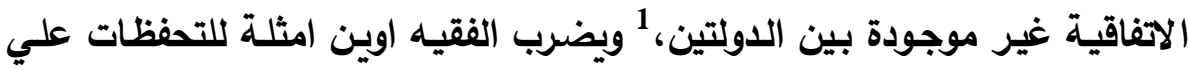

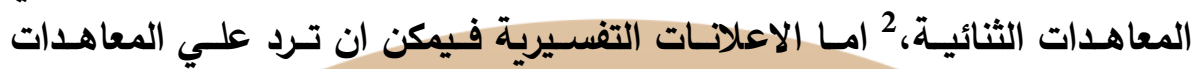
الثنائية كمـا ذكر في المبادئ التوجيهية للجنـة القانون الدولي حيث يعد الاعـلان التفسيري في هذه الحالة تفسيرا ملزما اذا وافقت عليه الدول التوحيه الاخري. 3 أما لجنة القانون الدولي فقد تبنت رأي الفقيه بيشوب Bishop في تقريرها

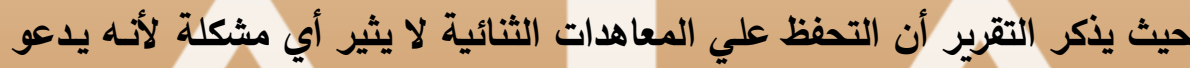

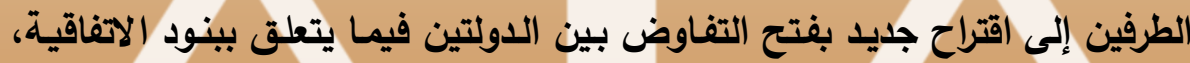

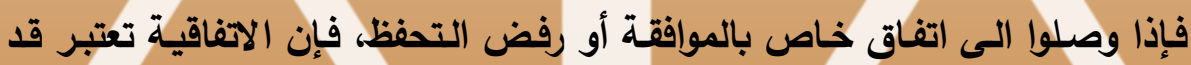

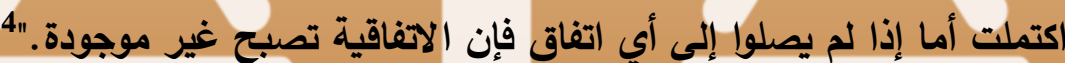

وقد قامت المجر باقتراح حذف الاتفاقات الجماعية من صياغة اتفاقية فيينا

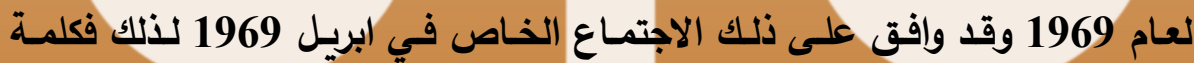

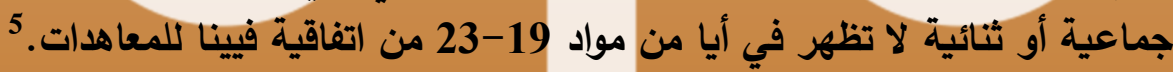

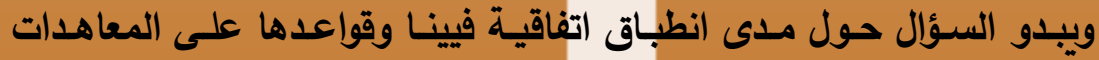

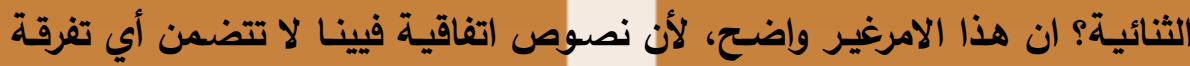

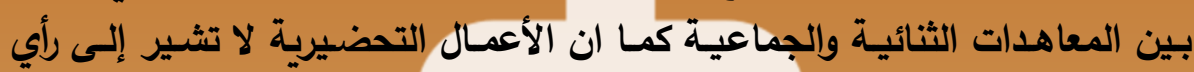

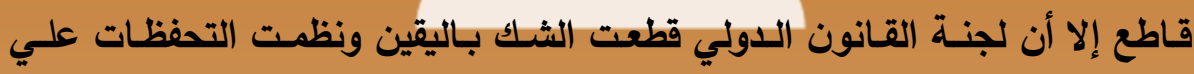
المعاهدات الثنائية واعتبرته اقتراح جديد بالتفاوض التون لتعديل الاتفاقية الثنائية.

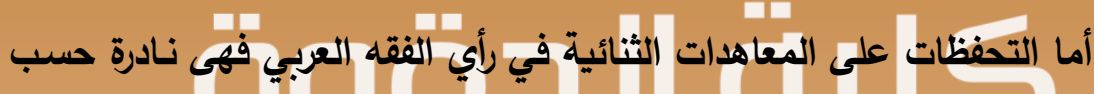

(1) Bishop, Reservations to treaties, op. cit. at 267.

(2) Marjorie Owen, Reservations to multilateral treaties, op. cit., p. 1092 (reservation on Treaty of Peace \& Amity between France and United States in 1800).

(3) ILC, 1.5.2 at 51 (draft guidelines 1.2 and 1.2.1 are applicable to interpretative declarations in respect of multilateral as well as bilateral treaties) and 1.5.3

(4) ILC 1966 Report at 23.

(5) Ibid. at 22. 
رأى الأستاذ الدكتور صـلاح عامر (1) ولُعل أول تحفظ على معاهدة ثنائية قد تم

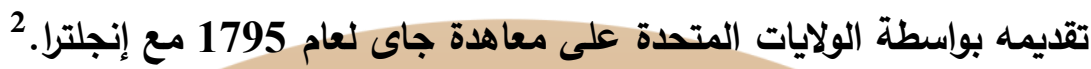

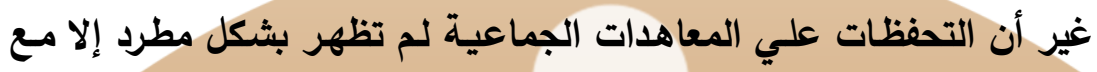

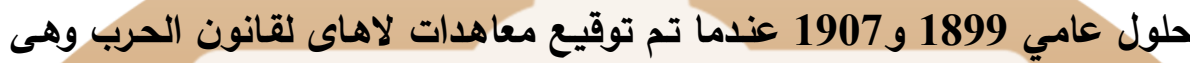

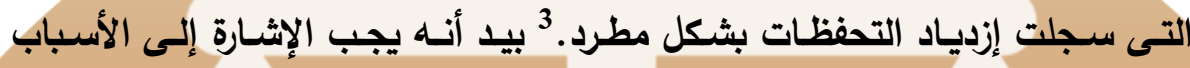

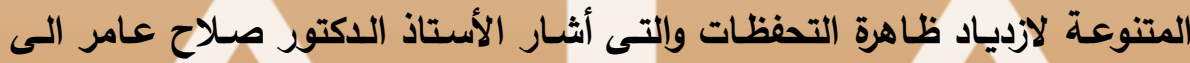

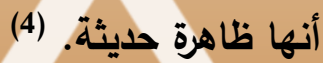
السباب زيلادة ظاهرة التمفظات

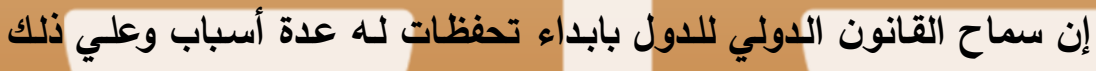

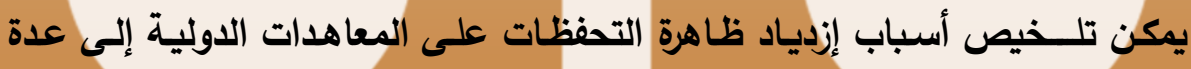

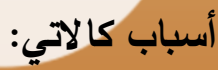

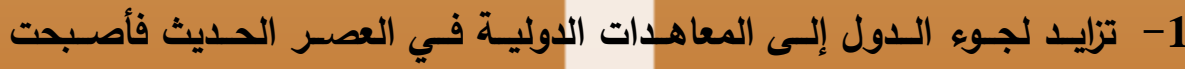

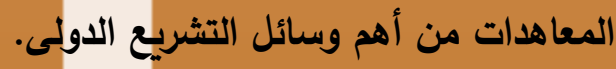
2- ازدياد عدد الدول التي تثترك في التفاوض وتوقيع المعاهدات.

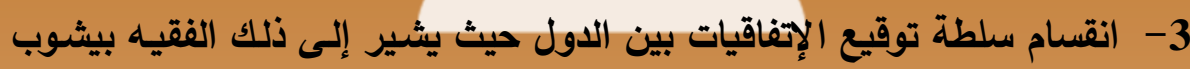

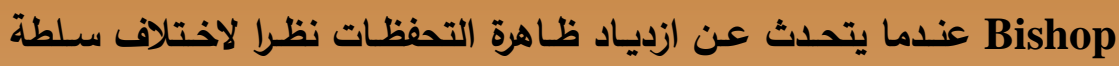

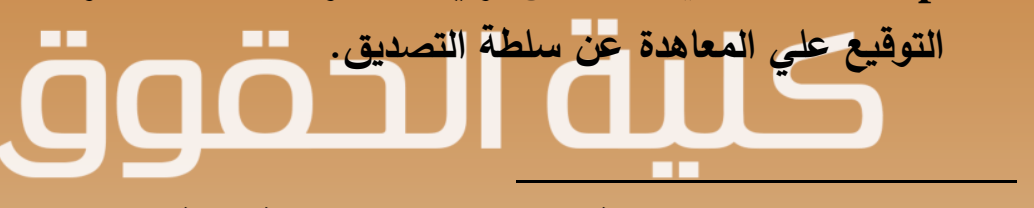

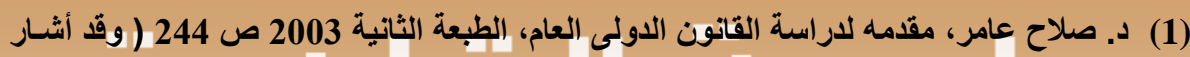

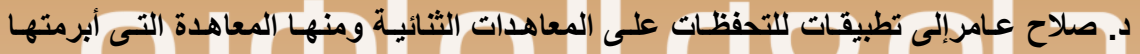

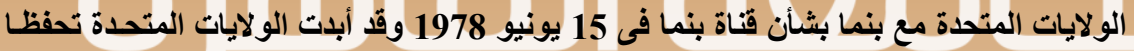

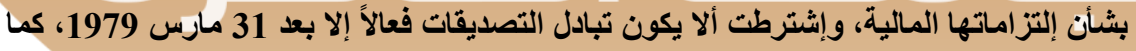

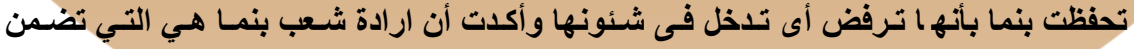

استقلالها السياسي وسلامة اقليمها).

(2) Bishop, Reservations to treaties, op. cit., at 260.

(3) Frank Horn, Reservations and interpretative declarations to multilateral treaties, op. cit.; p. 11.

(4) د. صلاح عامر مقدمه لدراسة القانون الدولى العام الطبعة الثانية ص 249 
4- الخلاف بين التشريع الداخلى والإلتزامات القانونية الدولية، اذ تلجأ الدول إلى الـى إبداء تحفظات لكي تقوم بالتوفيق بين الالتزامات الدولية والتشريعات الداخلية.

5- الاختلاف بين سياسات الدول المنضمة للاتفاقية الدولية. وفيما يلى تفصيل تلك الأسباب:

(1) السبب الأول: تراليد لجمي الدول إلى المعاهدات الدولية ميث أصبمت المعاهدات

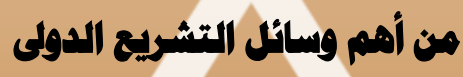

لاثك فى ارتباط ظاهرة التحفظات بظاهرة المعاهدات الدولية حيث أن مجال

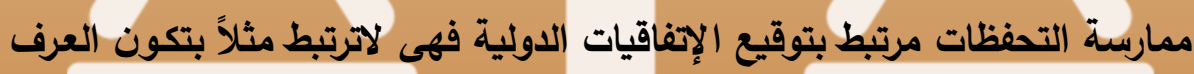

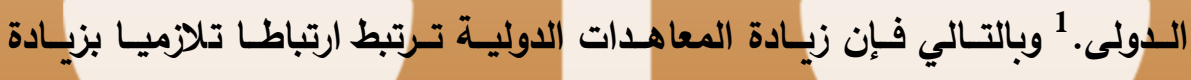
التحفظات علي المعاهدات الجماعية.

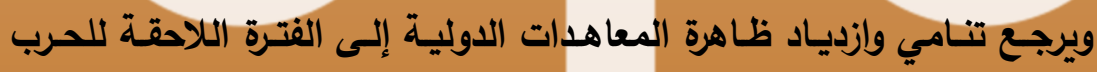

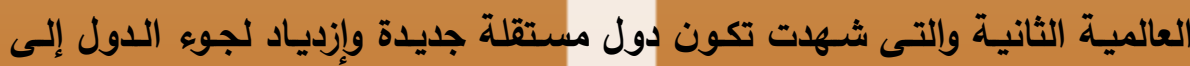

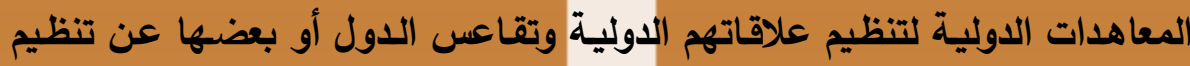

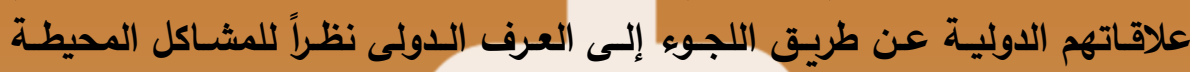

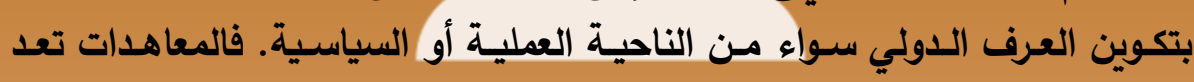

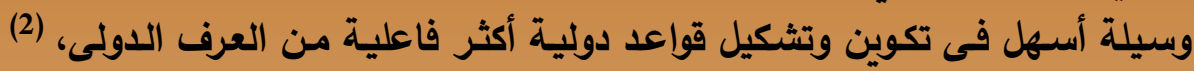

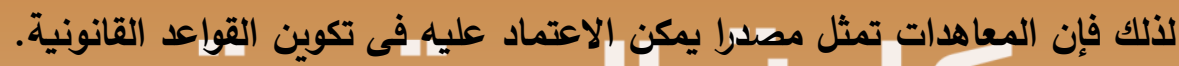

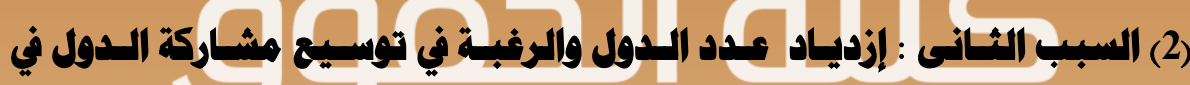
الاتماتيات البماوبية

إن تزايد الدول بشكل مستمر يؤدى إلى زيادة ظاهرة التحفظات، فالدول هي اللاعب الرئيسـي في تكـوين التحفظـات وإلــى جانـب المعاهـدات الثنائيـة فهنـالك

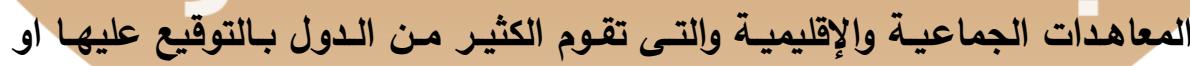

(1) Bishop, Reservations to treaties, op. cit., at 260.

(2) Frank Horn, Reservations and interpretative declarations to multilateral treaties, op. cit., p. 10-12. 


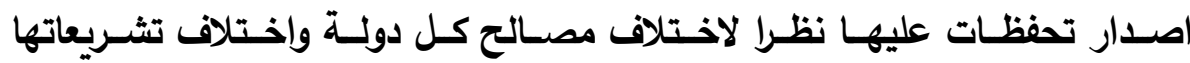

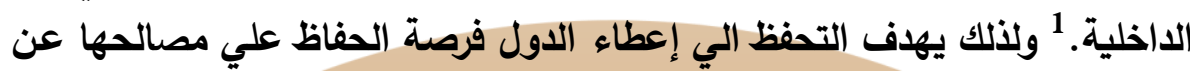

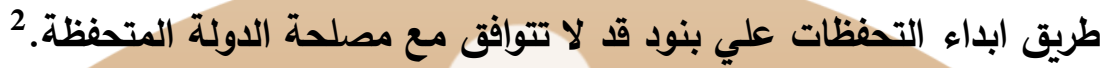

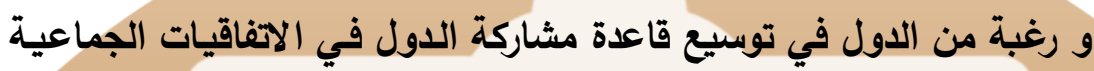

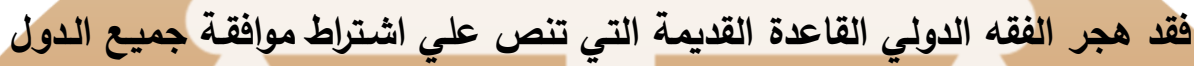

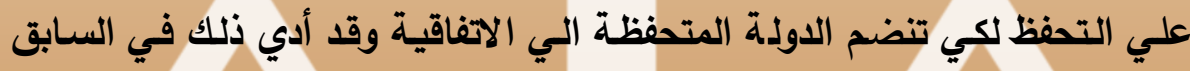

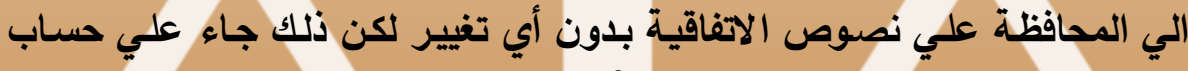

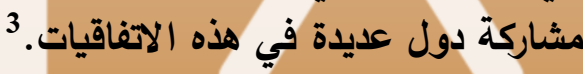
(3) السبب الثالث : إنتسام سلطة توقيج الإتفاقيات بين الدول

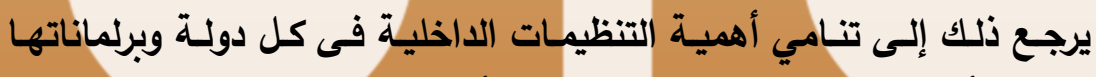
المختلفة حيث أصبح لها دور متزايد فى الموافقة أو عدم الموافقة على على الميات المعاهدات.

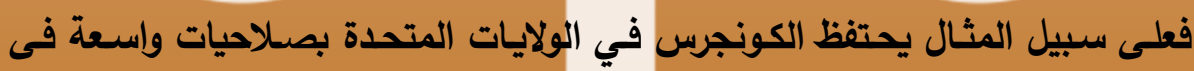
الموافقة على بنود الإخفاقية أو عدم التصديق علئها. 4

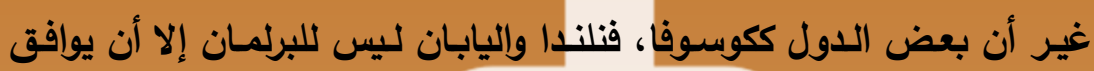

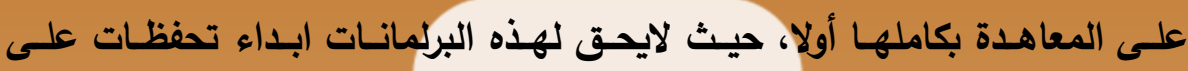
استقلال عن حكوماتهم. ويمكن القول بأن السبب في ازدياد وتنامي دور البرلمانات الداخلية بثـأن

(1) Daniel Hylton, Default breakdown: The Vienna convention on the law of treaties' inadequate framework on reservations, 27 Vand. J. Transnat'l L. 423 (1994).

(2) Richard Edwars, Jr. Reservations to Treaties, Michigan Journal of International Law, Vol.10:362, p. 350

(3) Henry J. Bourguignon, The Belilos case: new light on reservations to multilateral treaties, 29 Va. J. Int'l L. 347 (1988-89).

(4) Barry Carter, International law, Aspen publishers, p. 93-94 (United States); See also Bishop, Reservations to treaties, op. cit. at 263.

(5) Frank Horn, Reservations and interpretative declarations to multilateral treaties, Op. cit., p. 12-13. 
سلطة التصديق علـي المعاهـدات الدوليـة يرجـع الـي الرغبـة في عدم تـرك الامـر

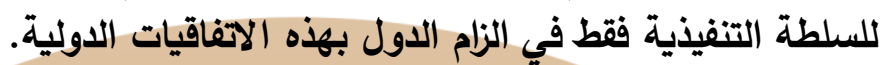
(4) السبب الرابع : أصداث تنافم وتهازن بـين الإلترامهات الدوليـة والتشـريعات الداخلية

تتضمن التحفظـات عدم إستعداد الدولـة لكى تغير تشريعاتها الداخلية لكى

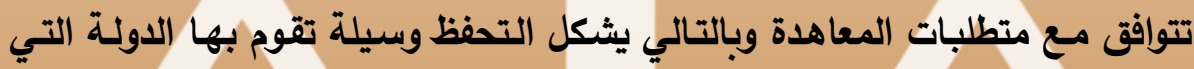

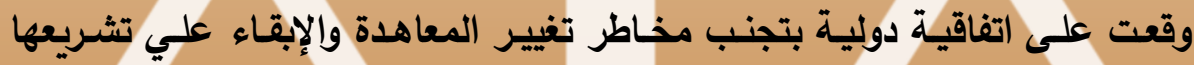

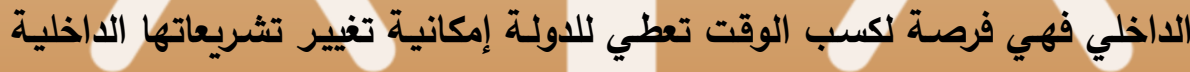

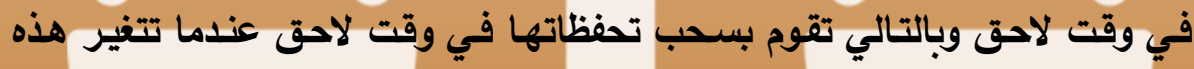

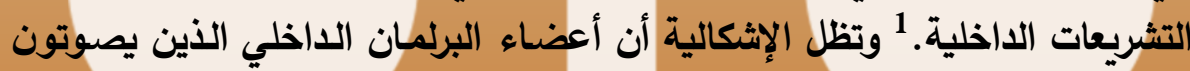

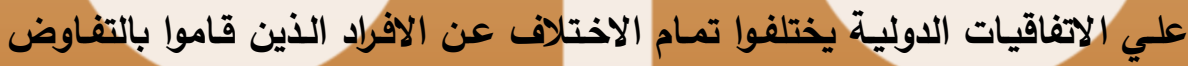
علي هذه الاتفاقية من داخل السلطة التنفيذية. 2 (5) السبب الغامسل: الختلاف سياسات الدول ومماقفها

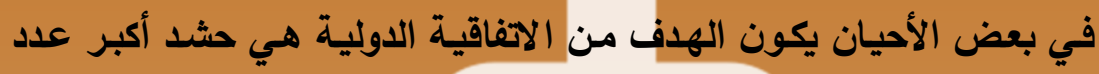

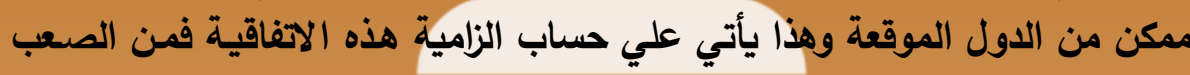

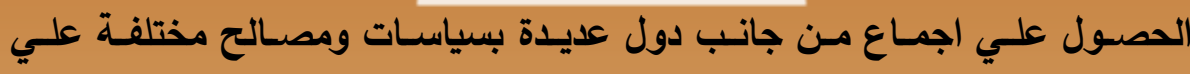

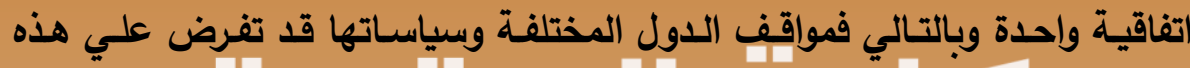

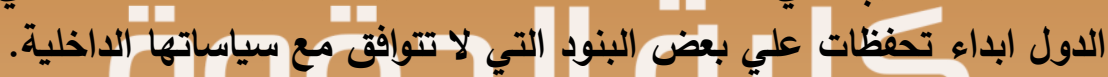

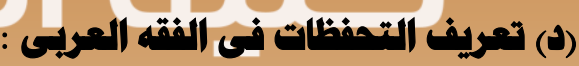

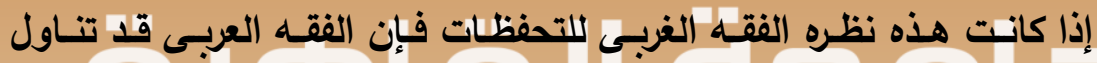
موضوع التحفظات بشكل كبير وأولاه اهتمامـاً كبيراً. فقد قام الأستاذ الدكتور سـامى فئه

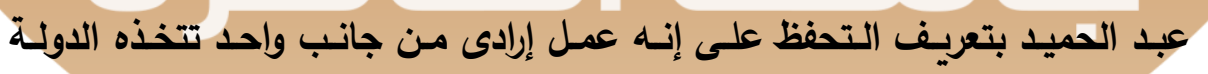

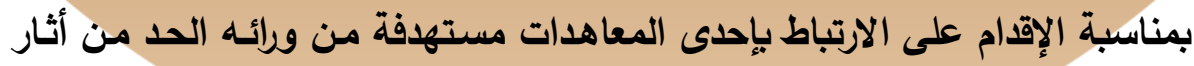

(1) Ibid., p. 234.

(2) Richard Edwars, Jr. Reservations to Treaties, Michigan Journal of International Law, Vol.10:362, p. 364 
المعاهدة المعنيـة فـى مواجهتها باستبعاد بعض أحكامهـا مـن نطاق إرتباطها أو

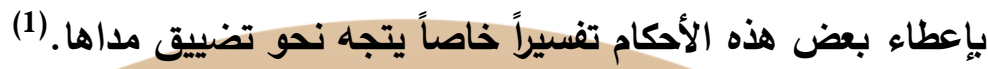

إلا أن القول باشتمال التحفظ علي التفسيرات الخاصة يؤدي الي حدوث خلط

بين التحفظات والإعلانات التفسيرية حيث يهدف التحفظات الي استبعاد أو تعديل

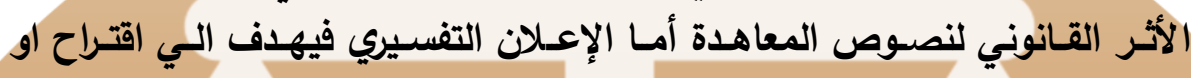
تطبيق تفسير معين دون غيره.

أما الدكتور محمد السعيد الدقاق فيعرف التحفظ على المعاهدات الدولية بأنها

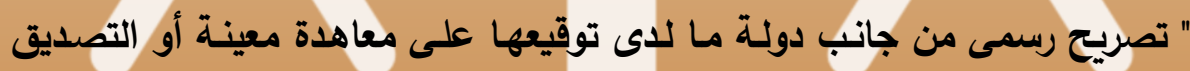

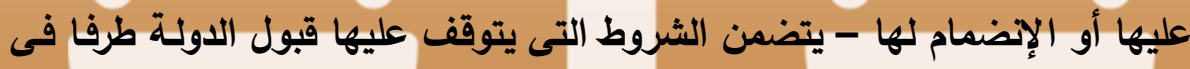

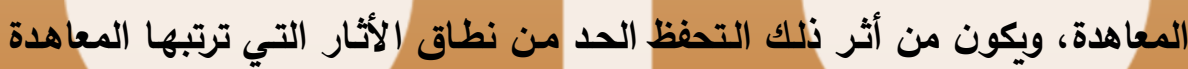

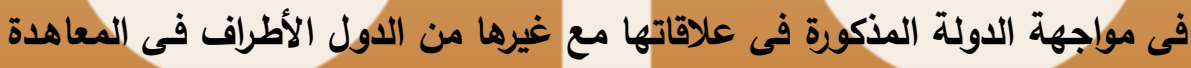

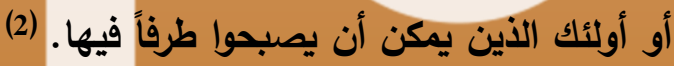

اما الاكتور احمد ابو الوفا فيعرف التحفظ علي انـه اعلان انفرادي ايا كان

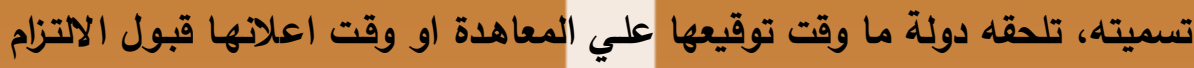

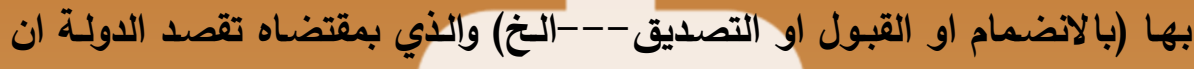

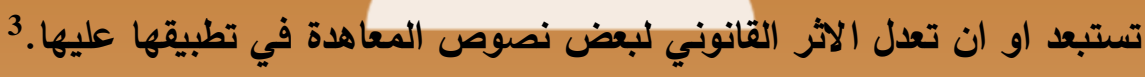
و يبدو أن هناتك نظريتين يشير إليهما الدكتور محمد السعيد الدقاق فى شأن

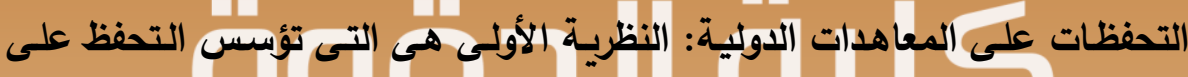

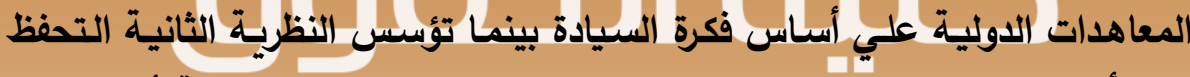

على أساس مقتضيات زيادة عدد الدول التى تنضم إلى المعاهدة الدولية. 4 غير أنـه يجدر الإشـارة الـي أن الفقـه الدولي قد انقسم حول تبني مفهوم

(1 ) د. محمد سـامى عبد الحميد، أصول القـانون الدولى العـام / الجزء الثانى / القاعدة الدوليـة، ص211-210 (2005 ) (211)

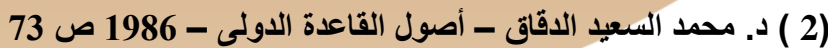

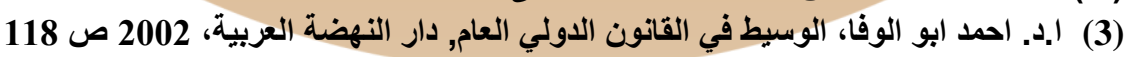

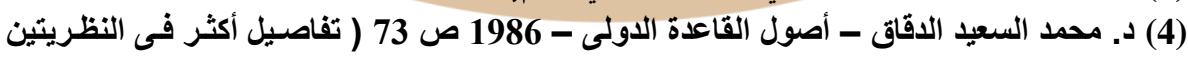

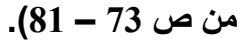


محدد للتحفظـات مـا بين انصـار المفهوم الواسـع للتحفظ بحيث يشمل الإعلانـات

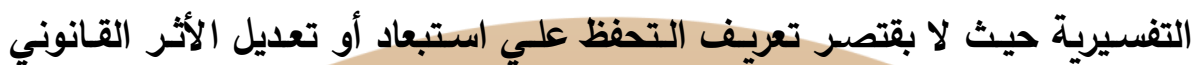

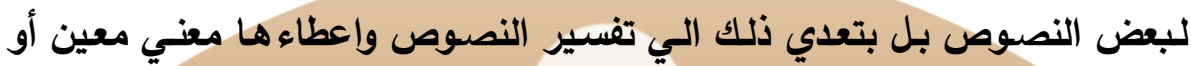
تفسير معين دون غيره وهذا الاتجاه لا يفرق بين التحفظات والإعلانـات التفسيرية أمها أنصار المفهوم الضيق فيأخذون بتفسير التحفظ في نطاق استبعاد أو تعديل

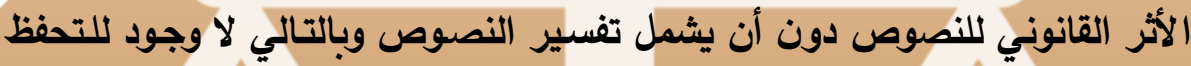
التفسيري وعلي هذا يكون الإعلان التفسيري مختلفا عن التحفظ. 1

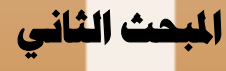 \\ أنواع التمفيات على الامعاهدات الدواية}

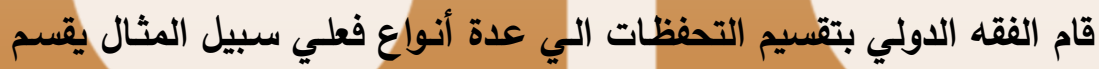

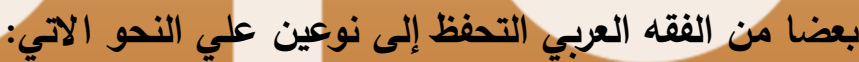

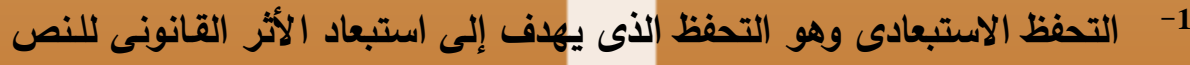

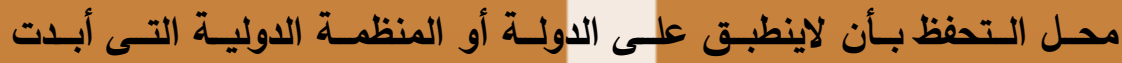

(2) التحفظ.

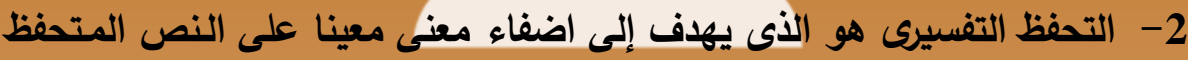

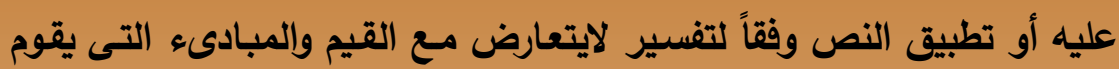

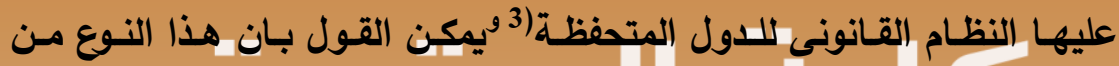

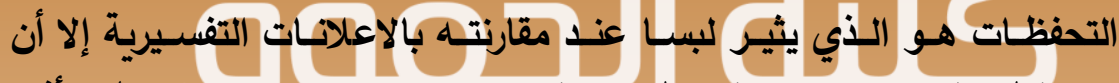

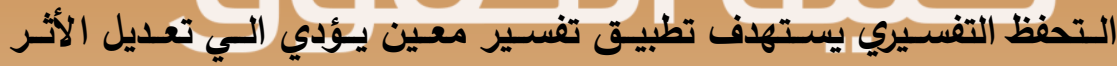

$$
\text { القانوني اللبند الوارد عليه التحفظ. }
$$

إلا أن هناك نوعا اخر أشار اليه بعضا من الفقه الدولي وهو التحفظ المعدل

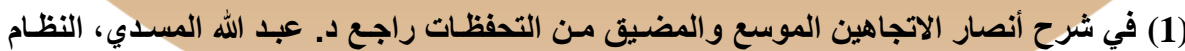

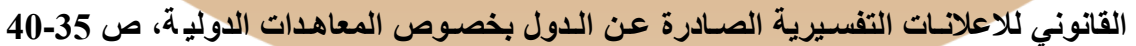

(2) ) د. إبراهيم العنانى، القانون الدولى العام، الطبعة الخامسة / 2004-2005.

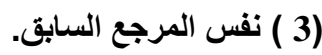


وهو التحفظ الذي يهدف الي تعديل النصوص التي ورد فيها الإعلان سواء عن كنوية طريق تعديل النص بطريقة كمية أو يطريقة كيفية.

ويقسم بعض الفقه الدولي بطريقة اخري التحفظات الي اقسام ثلاثة رئيسية

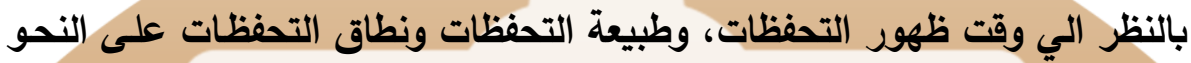

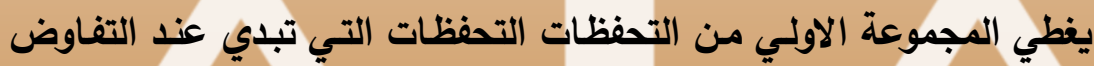

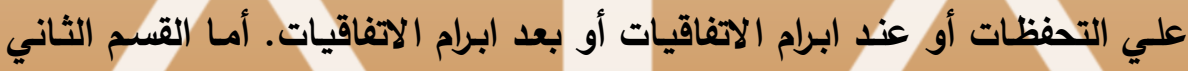

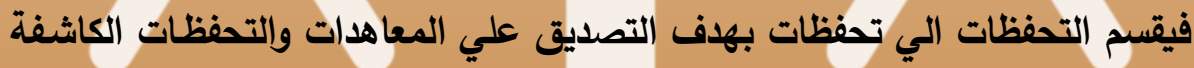

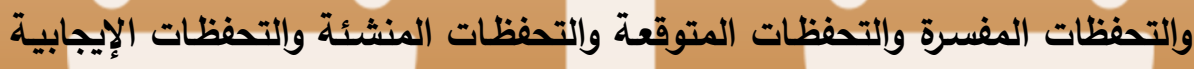

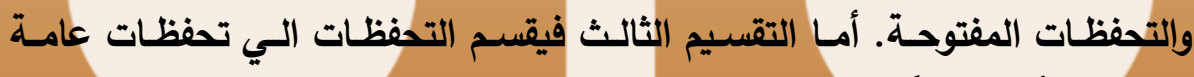

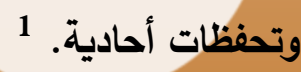

و قد قام بعض الفقه الدولي بتقسيم التحفظ الي تحفظ واسع (سلبي) وتحفظ إيجابي.

فالتحفظ السلبي أو التحفظ الواستع هو التحفظ الذي بمقتضـاه تقوم الدوبلة

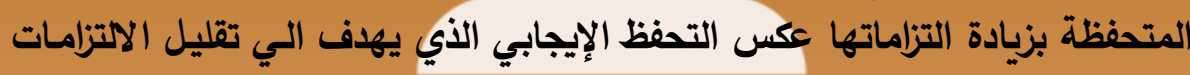

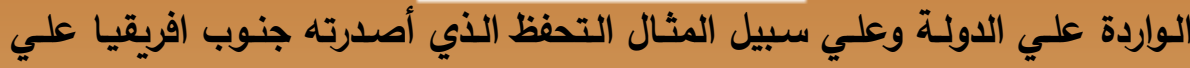

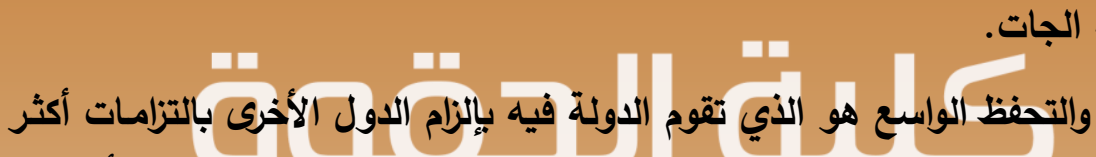

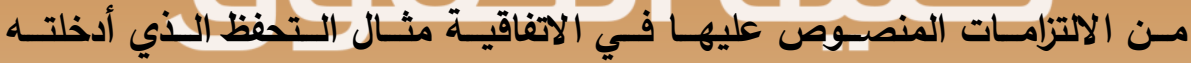

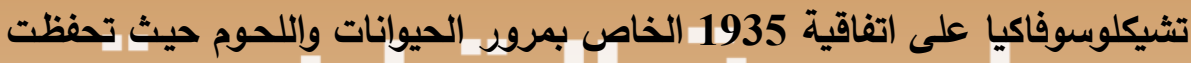

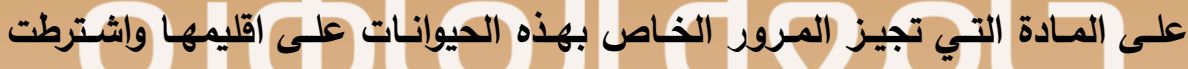

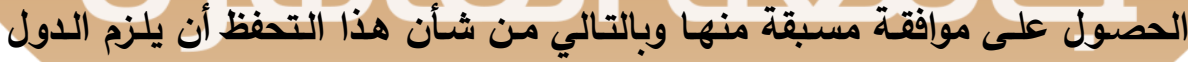

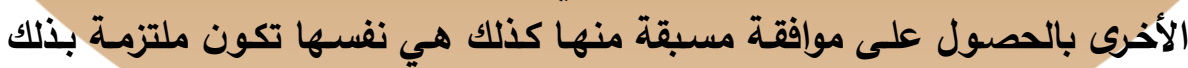

(1) Frank Horn, Reservations and interpretative declarations to multilateral treaties, op. cit.; p. 33-34 


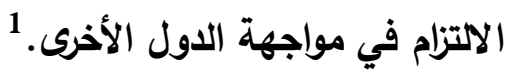

كمـا أنسه يمكن تقسيم التحفظ الي تحفظ صـريح وتحفظ مستتر، فالتحفظ

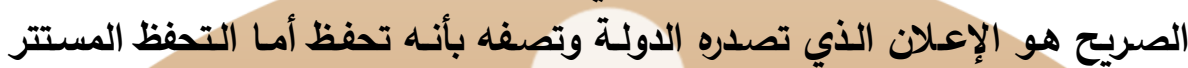

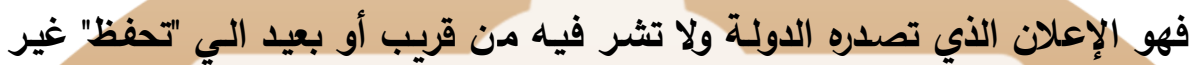

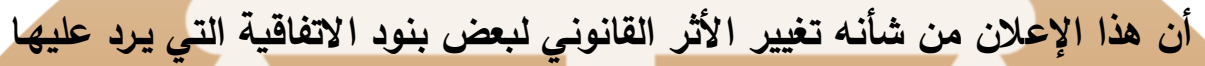
الإعلان وذلك على التفصيل الذي سيرد في المباحث التالية.

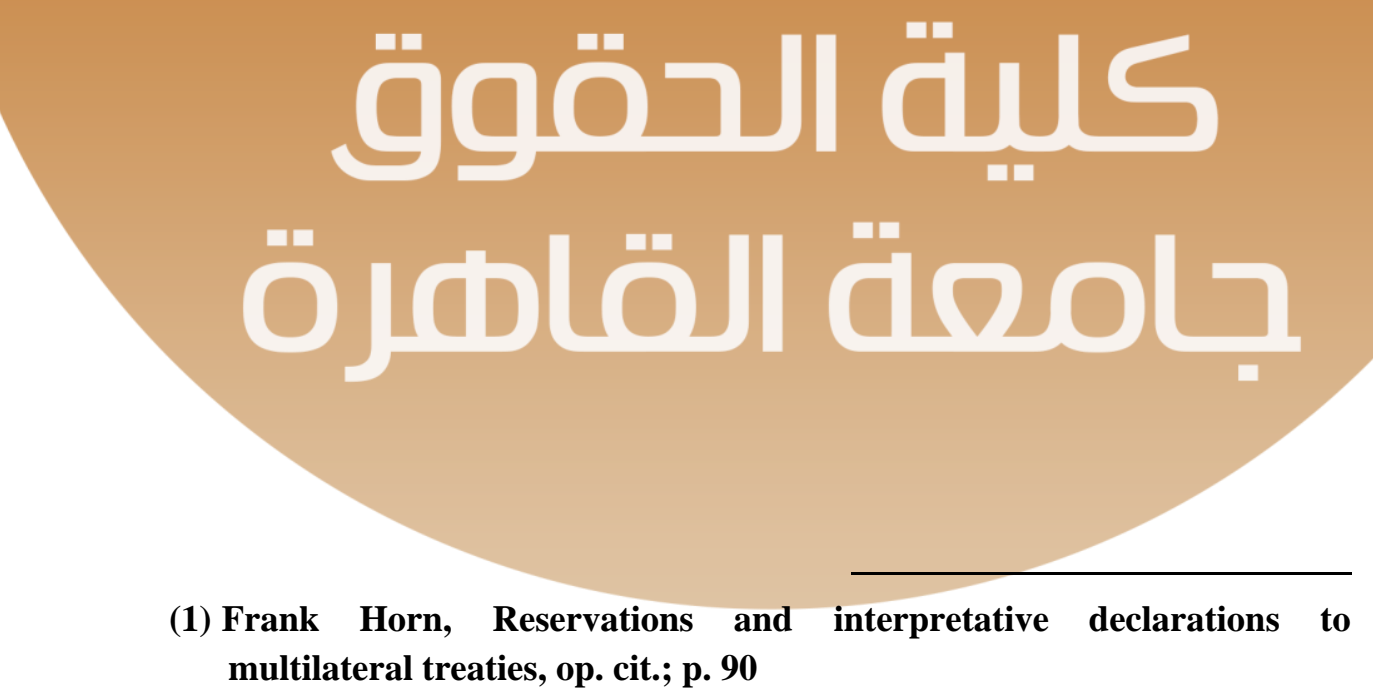




\section{النصل الثاني}

\section{التفرقة بين التمفظات المسترة والإعلانات التفسيرية}

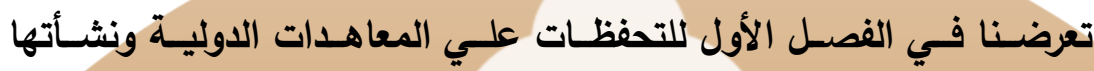

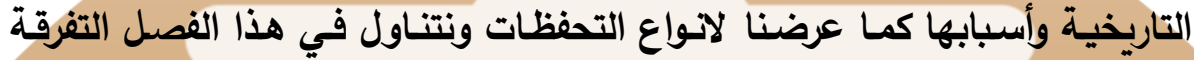

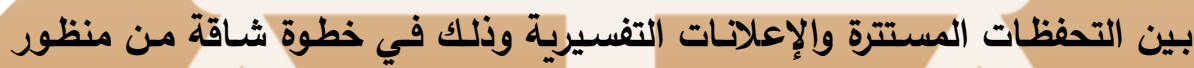

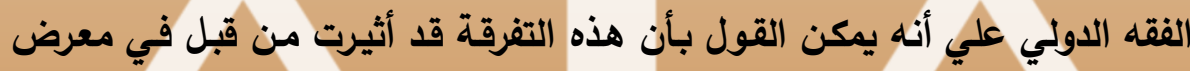

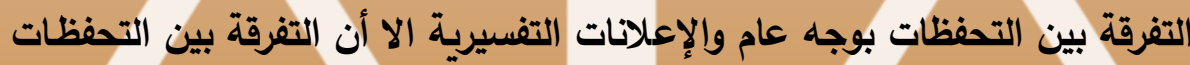

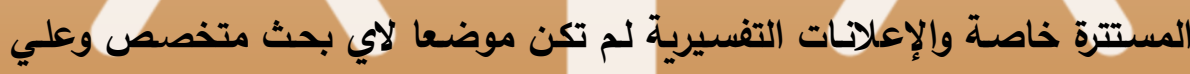

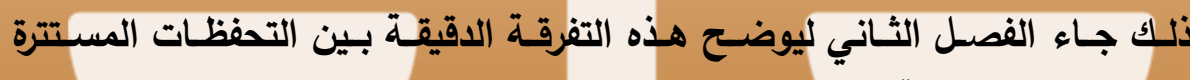
والإعلانات التفسيرية.

وقد وضح الفقه الدولي التفرقة بين الإعلانات التفسيرية والتحفظات وتعديل

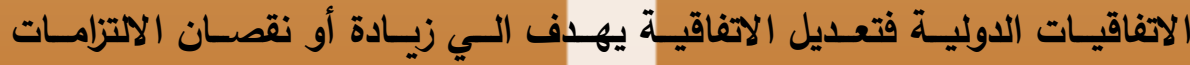

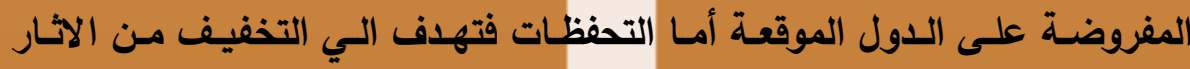

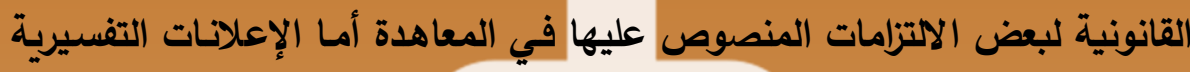

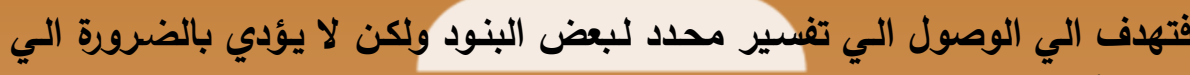

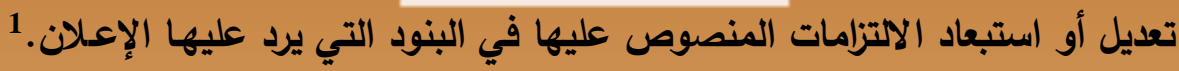

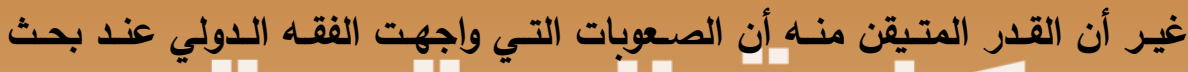

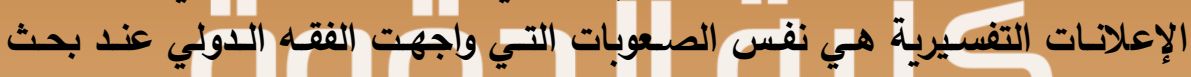
التحفظات على المعاهدات الدولية.2 الاعلية

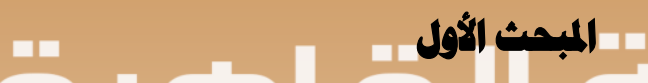 \\ ماهية التمفظات المسترة على المعاهدات (الدولية}

يندر أن نجد تعريف جامع وشامل للتحفظات المستترة فكما ذكرنا من قبل أن

(1) Richard Edwars, Jr. Reservations to Treaties, Michigan Journal of International Law, Vol.10:362, p. 380

(2) Frank Horn, Reservations and interpretative declarations to multilateral treaties, op. cit.; p. 235 
الفقه الدولي لـ يتعرض لههذا النوع من التحفظات بالبحث الكافي أو المستفيض المهات

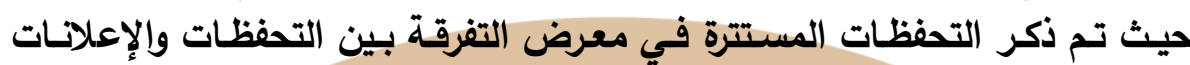

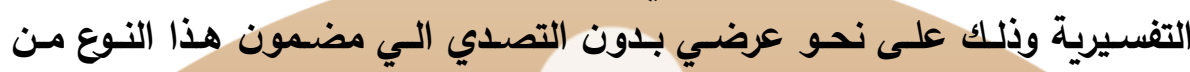
التحفظات وأسبابه وملامحه الرئيسية.

إلا أنـهـ يمكن تعربـف التحفظـات المستترة بأنها اعلاتـات الاتفراديـة تصدرها

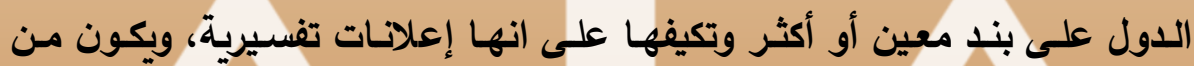

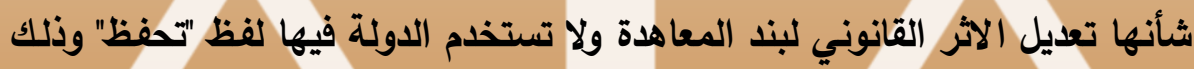

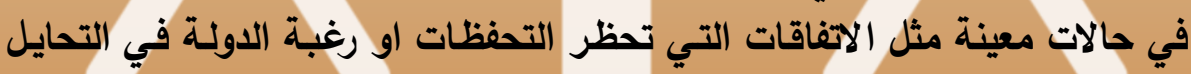
على النظام القانوني للتحفظات. ويمكن القول بوجود أربعة فرضيات تحكم التحفظات وهي كالاتي:

تحظر الاتفاقية جميع أشكال التحفظات أيا كانت وهذا هو الفرض الاول، أمـا

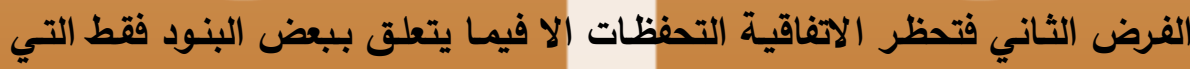

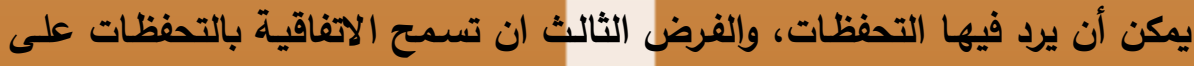

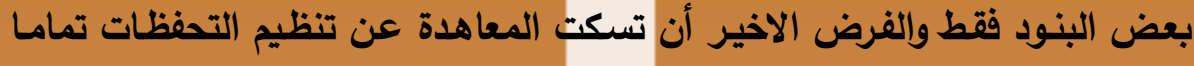

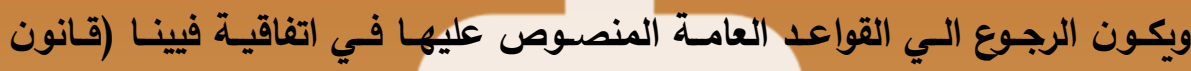
(المعاهدات).

وتثور هذه المشكلة الخاصة بالتحفظات المستترة في حالة المعاهدات التي

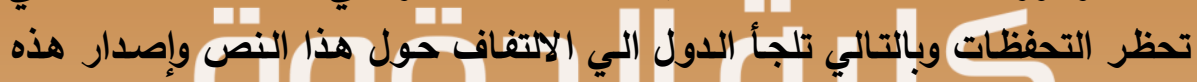

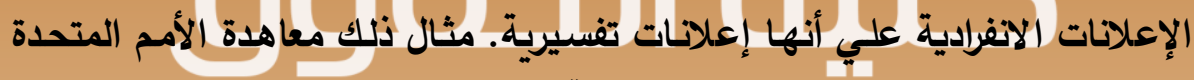

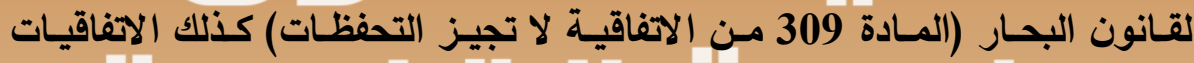

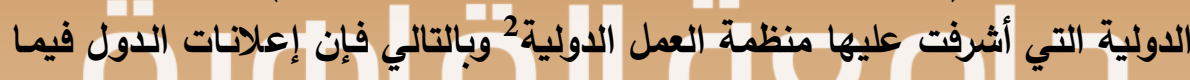

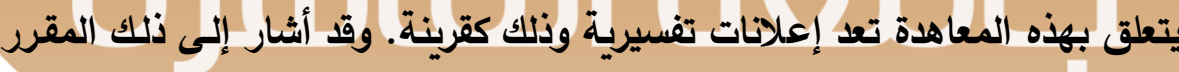

(1) L.D.M. Nelson, Declartions, Statements and Disguised Reservations with respect to the Convention on the Law of the Sea, International and Comparative Law Quarterly, Vol. 50 p. 767.

(2) Richard Edwars, Jr. Reservations to Treaties, Michigan Journal of International Law, Vol.10:362, p. 384 


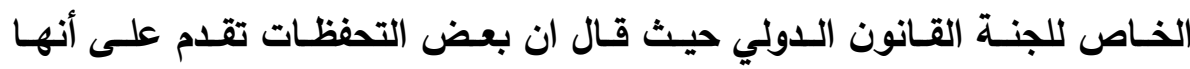
اعلانات تفسيرية وذلك للالتفاف حول الحظر الوارد على التحفظ الوارد في المعاهدة التي تنطبق عليه.

فعلي سبيل المثال فإن الاعلان الذي اصدرته الفلبين عند قيامها بالتصديق

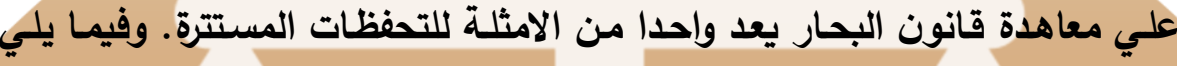
نص الاعلان: تصن معاهن

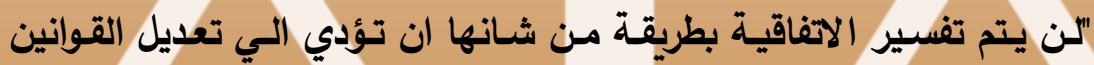

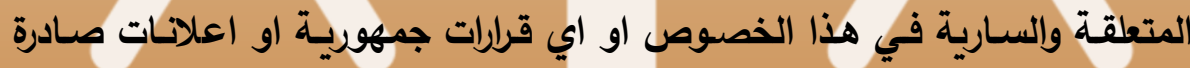

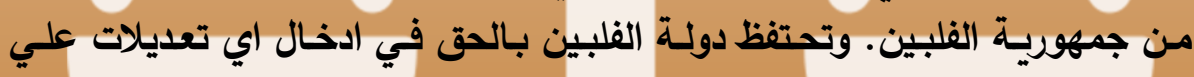

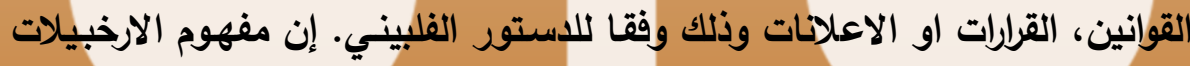
يعد مثابها لمفهوم المياه الداخلية وفقا للاستور الفلبيني."

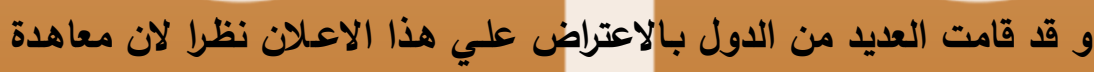

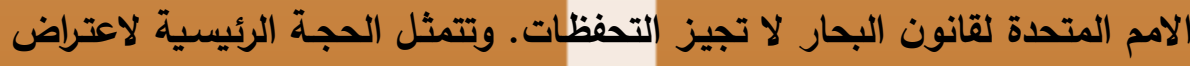

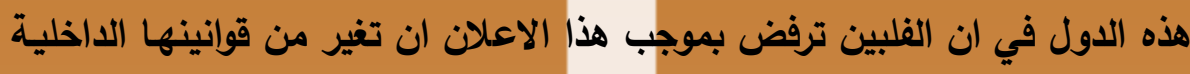

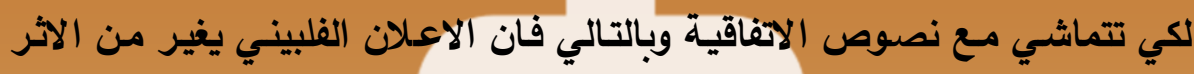

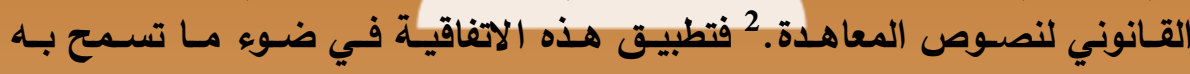
التشريعات الداخلية الفلبينية.

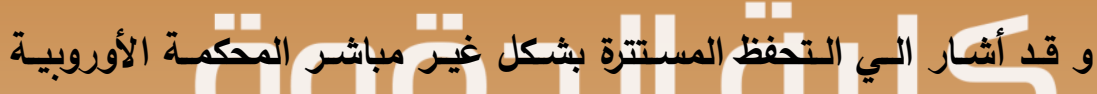

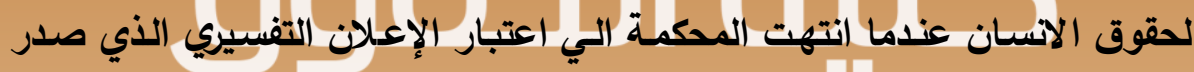

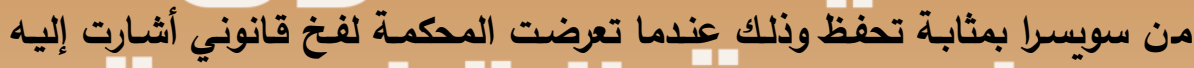

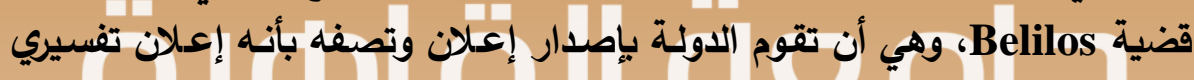

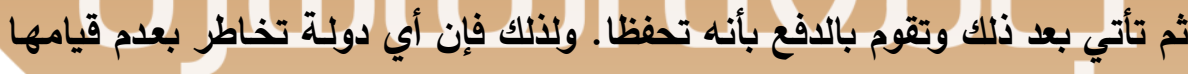

(1) International law commission, 1999 v.II pt.2 U.N.Y.B. Int'l L. Comm'n 1031999 at paragraph 3; See also P. Nelson, Declarations, statements and disguised reservations with respect to the convention on the law of the sea, op. cit., p. 767.

(2) Ibid., at p. 780. 
بالاعتراض على الإعلان التفسيري وقت صدوره لأنسه في تلك الحالـة قد تستخدم

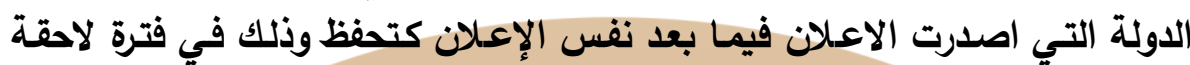

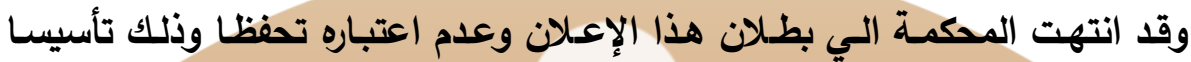
علي أن المعيار في تكييف الإعلان الصـادر من الدولـة لا يكمن في التسمية التي الاعني أضفتها علي الإعلان وإنما المحتوي الموضوعي الاعلان المادئ مها الاعلان. 1

كذلك فقــ قامـت محكمـة التحكيم في قضسية الرصسيف القـاري بـين فرنسـا

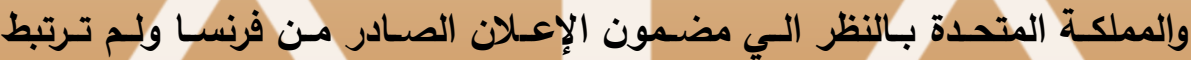
بالتكيف أو التسمية التي ألحقتها فرنسا بهذا الإعلان. أسباب ومبردات لجمي الدول الي التمنظات المستتزة:

لـم يهتم الفقـه الـدولي بتحليل أسباب لجوء الدول الـي التحفظـات المستترة

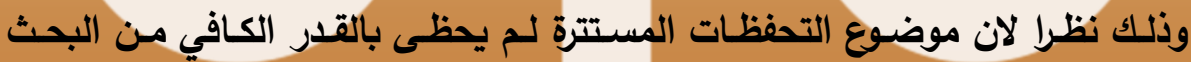

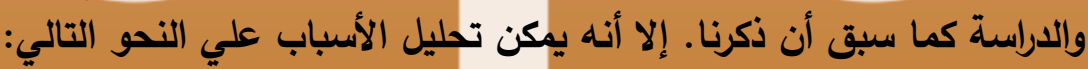
السبب الأول: رغبة الدول في الالتفاف حول نظام التحفظات ومـا يرتبط بـا

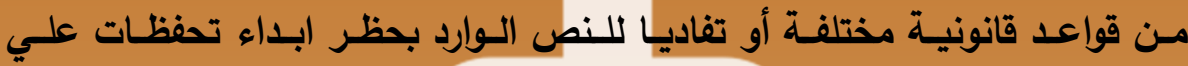

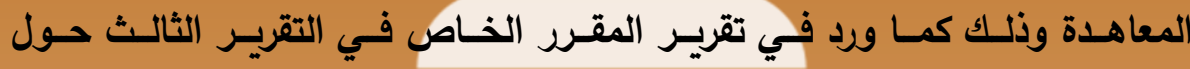

(1) In order to establish the legal character of such a declaration, one must look behind the title given to it and seek todetermine the substantive content. In the present case, it appears that Switzerland meant to remove certain categories of proceedings from the ambit of Article $6 \S 1$ (art. 6-1) and to secure itself against an interpretation of that Article (art. 6-1) which it considered to be too broad. However, the Court must see to it that the obligations arising under the Convention are not subject to restrictions which would not satisfy the requirements ofArticle 64 (art. 64) as regards reservations. Accordingly, it will examine the validity of the interpretative eclaration in question, as in the case ofa reservation, in the context of this provision. The European Court of Human Rights on the Application no. 10328/83.

(2) Richard Edwars, Jr. Reservations to Treaties, Michigan Journal of International Law, Vol.10:362, p. 369 
التحفظات.

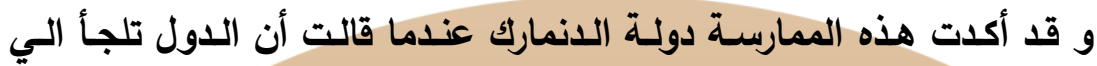

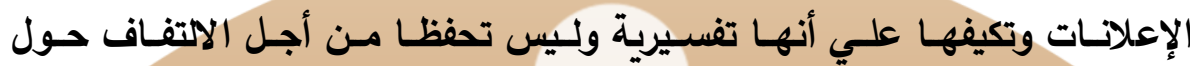

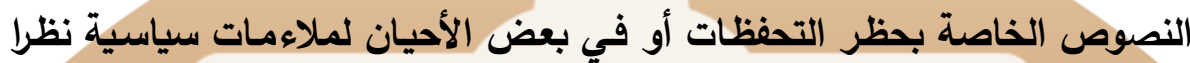

لان أبداء اعلان تفسيري علي بند معين أفضل سياسيا للدول عن ابداء تحفظ. 2

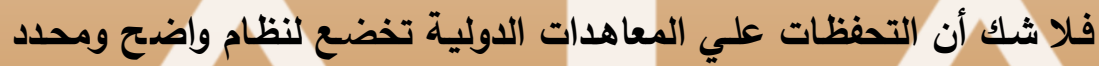

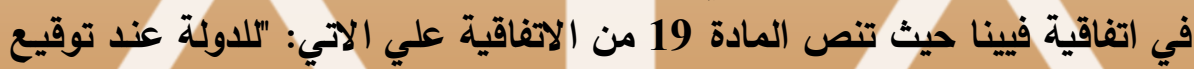

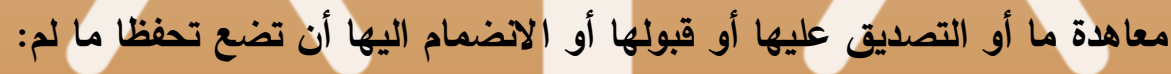

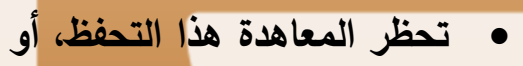

ما لم تنص المعاهدة علي أنه لا يجوز أن توضع الا تحفظات محددة ليس

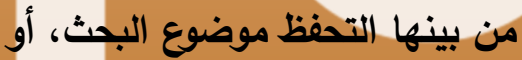

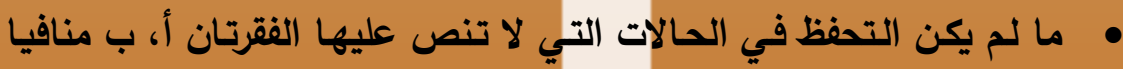
ل الموضوع المعاهدة وغرضها.

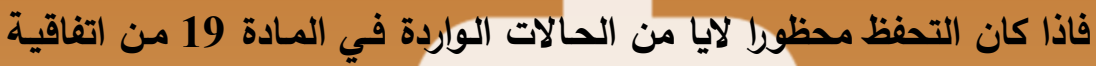

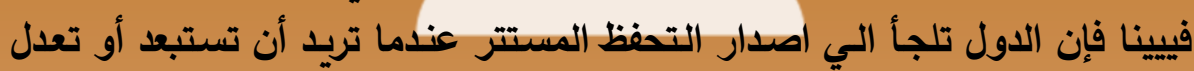
من الأثر القانوني لبعض النصوص مع التمسك بلدخول الاتفاقية كطرف فيها.

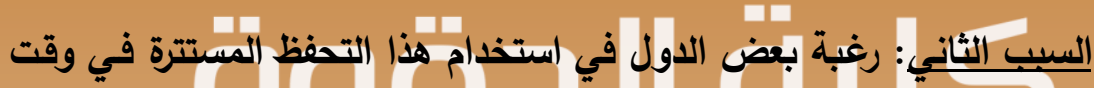

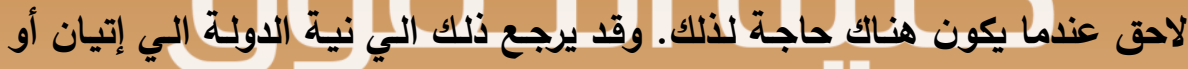

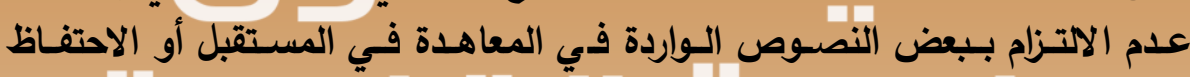

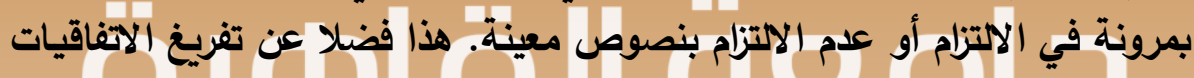

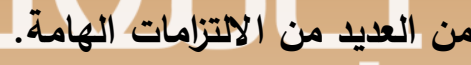

(1) L.D.M. Nelson, Declartions, Statements and Disguised Reservations with respect to the Convention on the Law of the Sea, International and Comparative Law Quarterly, Vol. 50 p. 779.

(2) Id. 


\section{الملامهح الرنيسية للتمفظات المسترترة:}

يمكن القول بوجود عناصـر رئيسية يجب توافرهـا من أجل القول بأن هذا

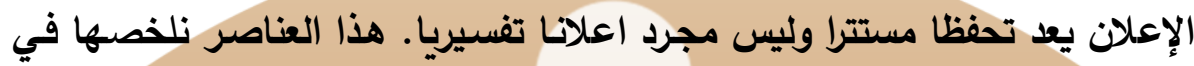
العناصر الآية: 1- اعلان انفرادي تصدره الدولة بصدد اتفاقية جماعية إن الـتحفظ المسـترة هـو اعـلان انفـرادي شـأنه فـي ذلـك شــأن الإعـلان

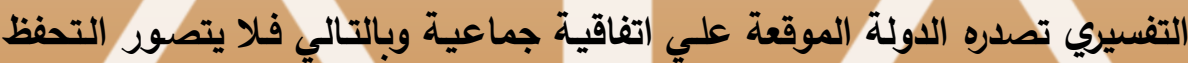
المستترة أذا كانت الدولة لم توقع علي هذه الهيه الاتفاقية. 2- يرد هذا الإعلان الانفرادي علي بند معين أو نص معين في المعاهدة يجب أن يرد التحفظ المستترة علي بند معين في المعاهدة فلا يتصور أن يرد

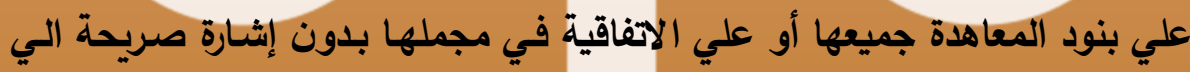

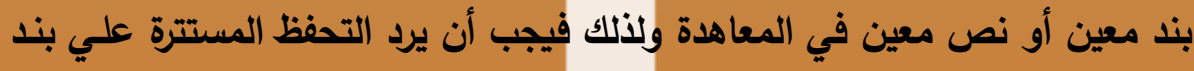

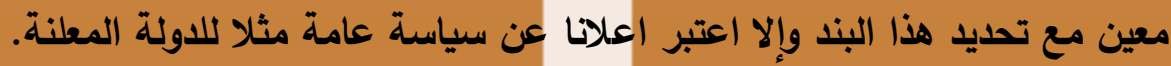
3- تقوم الدولة بتكييف هذا الإعلان علي أنه اعلان تفسيري

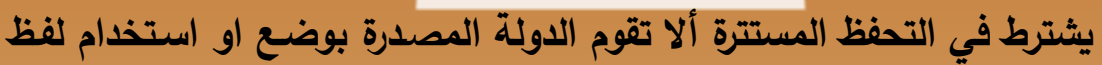

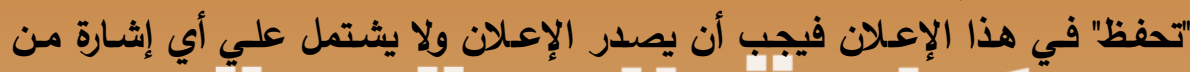

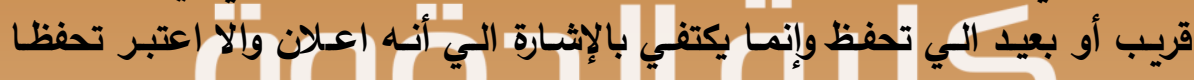
صربحا. 4- أثر هذا الإعلان هو تغيير أو تعديل الأثر القانوني لبنود المعاهدة. و يشترط في التحفظ المستترة أن يكون من شأنه أن يغير من الأثر القانوني

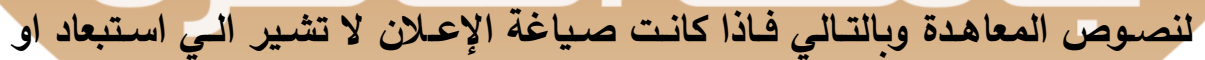

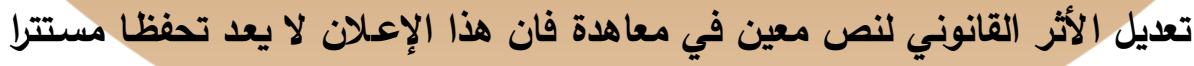

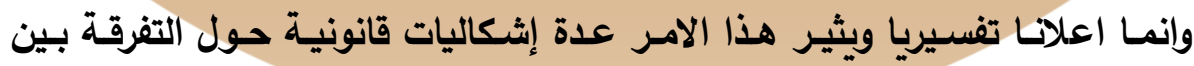

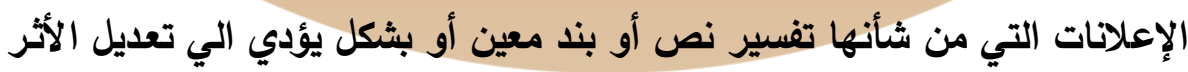

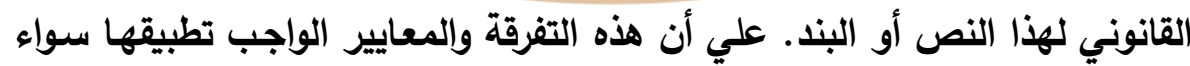




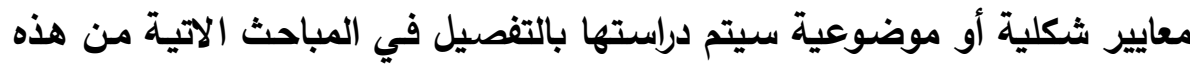

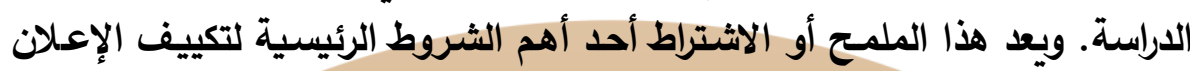
علي أنه تحفظ مستتر.

فكما أشار الفقية فيتزمويس الي ان الإعلان التفسيري لا يهرف الهي تغيير

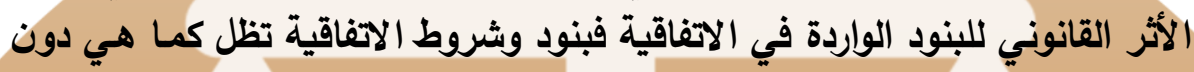

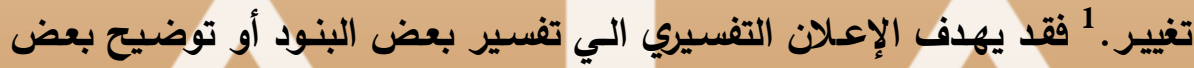

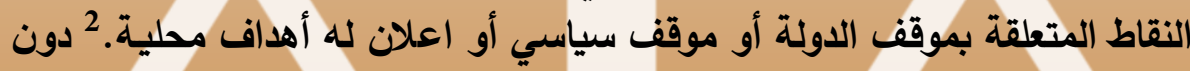
تغيير الأثر القانوني للبند.

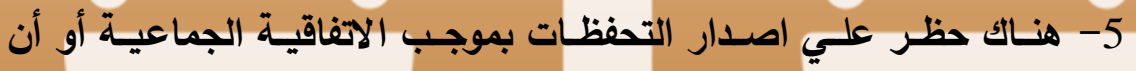
اصدار التحفظ غير مسموح به.

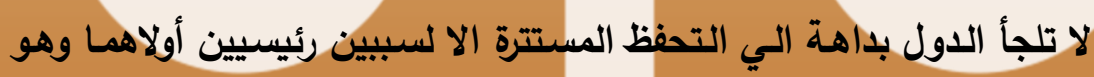

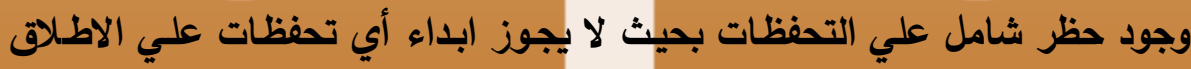

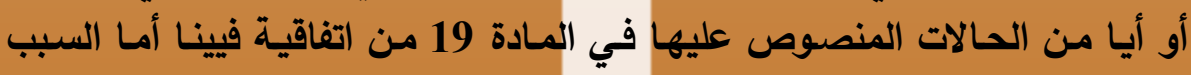

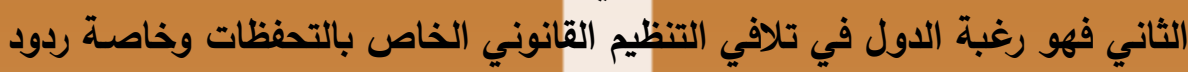

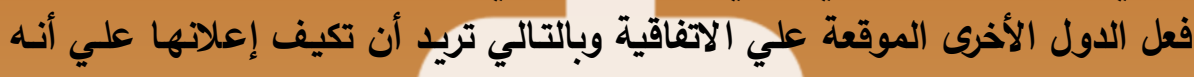
ليس تحفظا.

غير أن هذا العنصر ليس بلازم نظرا لكون بعض الدول تلجأ الي التحفظات

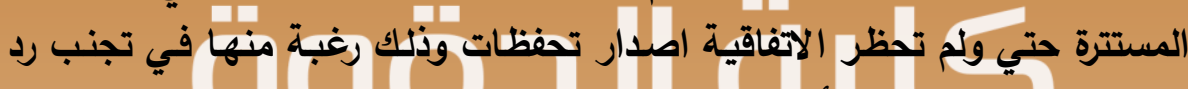

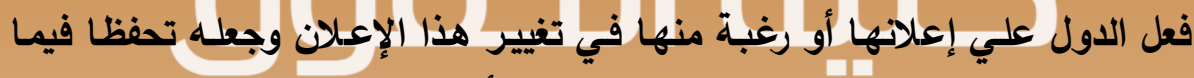

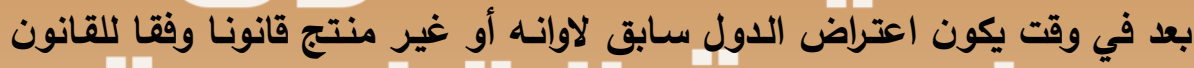

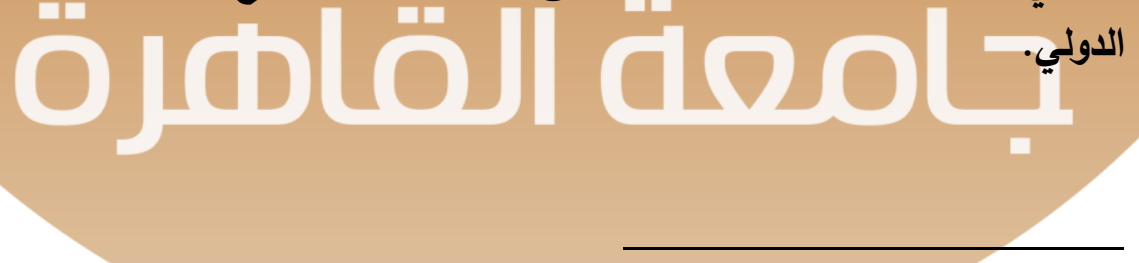

(1) P. Nelson, Declarations, statements and disguised reservations with respect to the convention on the law of the sea, International law and Comparative law Quarterly, vol. 50. no. 4 (oct. 2001), p. 770

(2) Id. 
6- هناك اعتراض من بعض الدول علي هذه الإعلانـات أو رد فعل من الدول

$$
\text { الأخرى علي نفس الاتفاقية }
$$

لا شك أن الدول الأخرى الموقعة علي أي اتفاقية جماعية لليهم الحق في

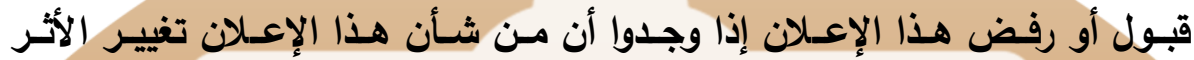

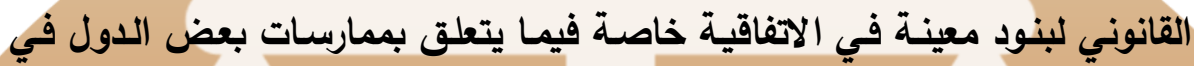

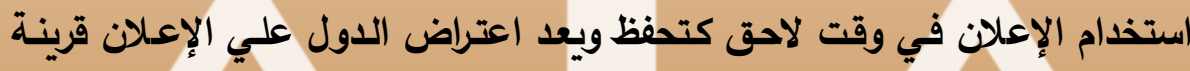

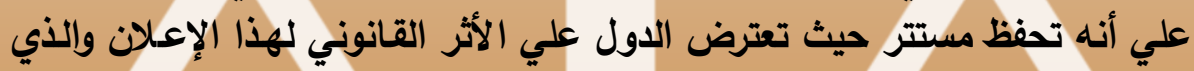

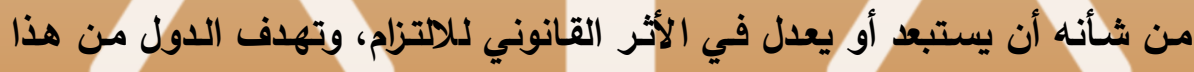

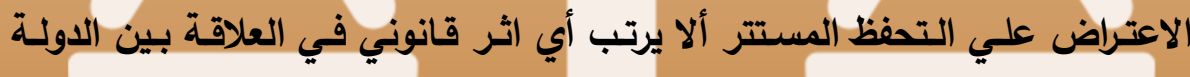

المعلنة وإلدولة المعترضة.

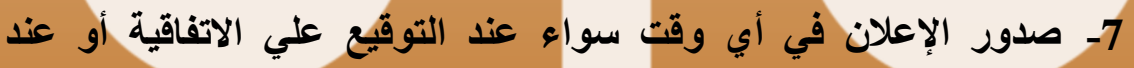

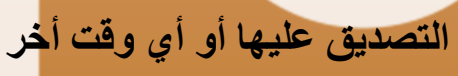

يشترط القانون الدولي وقتا معينا لصدور التحفظات علي المعاهدات الدولية

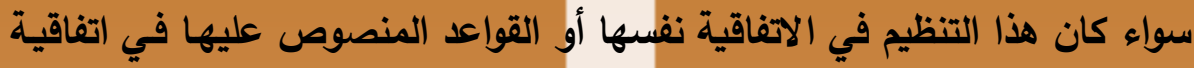

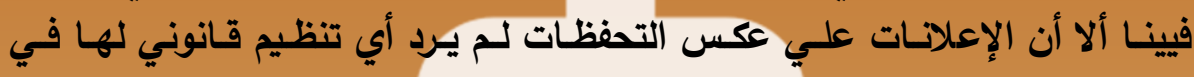

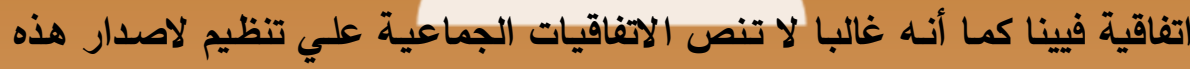

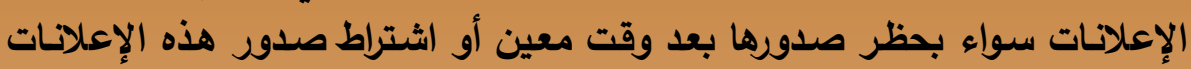
في وقت معين وذلك لكي تكون نافذة. و علي ذلك فهناك عدة أوجـه تثترك فيهـا التحفظات المستترة والإعلانـات التفسيرية وهما العناصر الآية:

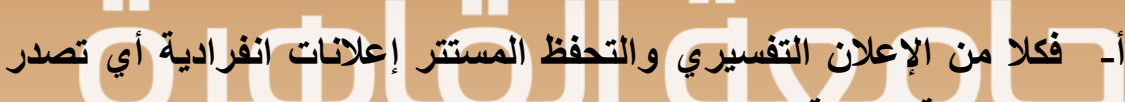
من الدولة المعلنة بمصض ارادتها ويصدر علي نحو مستثل عن المعاهدة الرعزية

(1) د. عبد الله المسدي، النظام القانوني للاعلانات التفسيرية الصادرة عن الدول بخصوص المعاهدات الدولية، ص الد 81 (2004) (1) (1) 
في وثيقة اخري مستقلة.1 ويمكن الإثشارة الي تماثل الثروط الثكلية

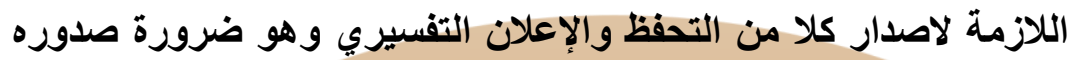

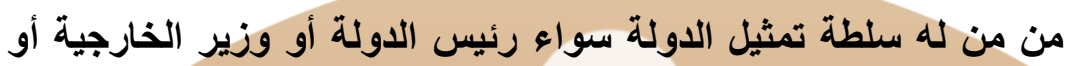
رئيس الحكومة أو المثثلون المعتمدون أو رؤساء البعثات الدائمة.2 بـ أن كلا من الإعلان التفسيري والتحفظ المستترة هما إعلانات مكتوبة.

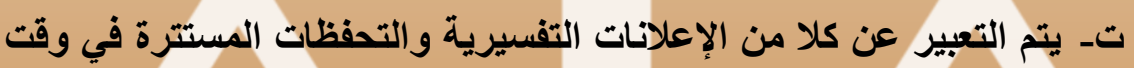

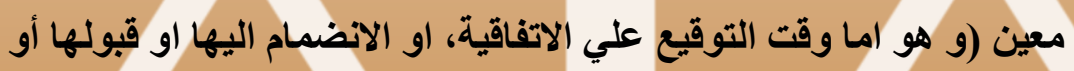

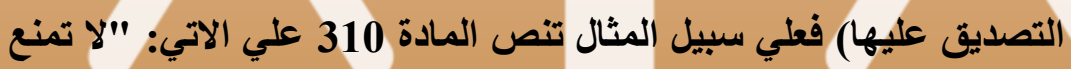

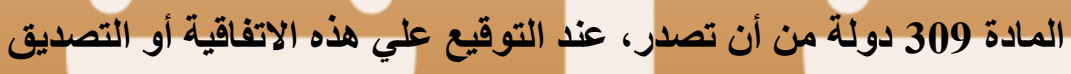

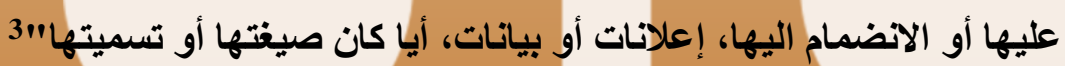

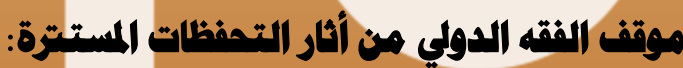

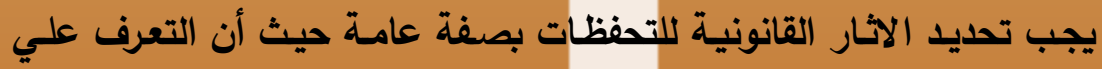

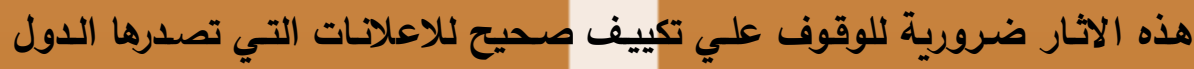

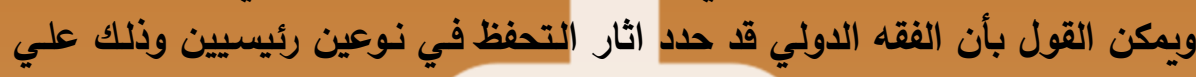

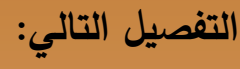

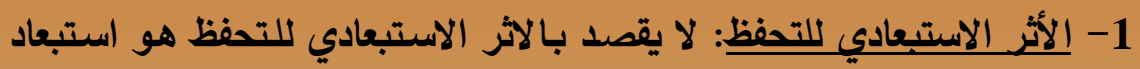

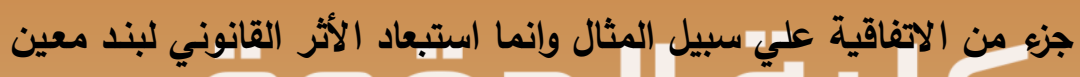

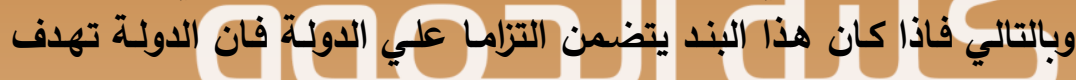

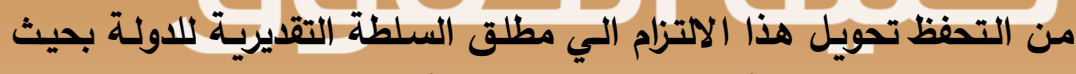

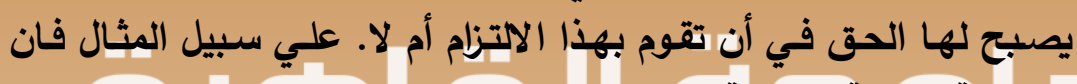

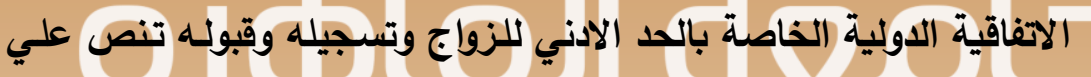

(1) د. عبد الله المسدي، النظام القانوني للاعلانات التفسيرية الصادرة عن الدول بخصوص المعاهدات

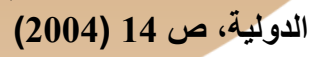

(2) نفس المرجع السـابق ص 15 حيثة يذهب الدكتور عادل المسدي الي إمكانيحة تطبيق المبدأ.

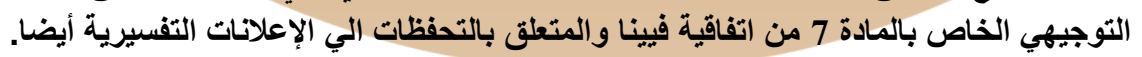

نفس المرجع السابق، صالس 15-314

(3) United Nations Convention on the law of the Sea (Article 309 and 310) 
أنه يجب علي الدول الأعضاء أن تسمح بالزواج بناء علي تفويض إلا أن

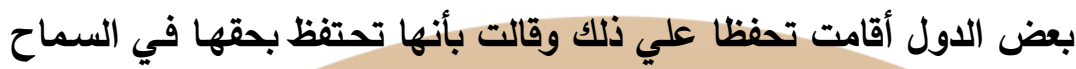
بهذا النوع من الزواج أو لا. 1.

2- الأثخر المعدل للتحفظ: وقد قسم الفقـه اللدولي الأثر المعدل للتحفظ الـي

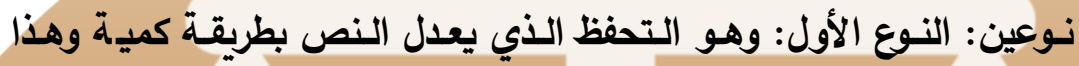

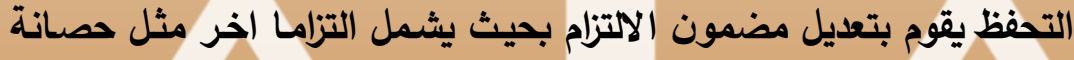

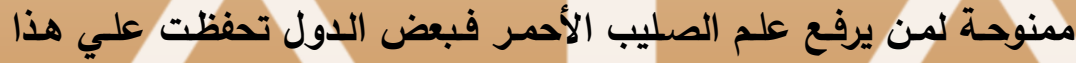

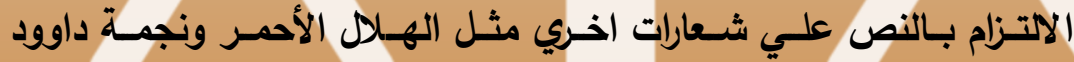

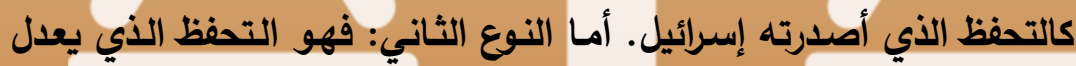

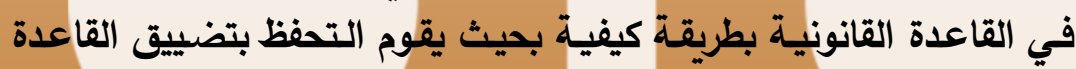

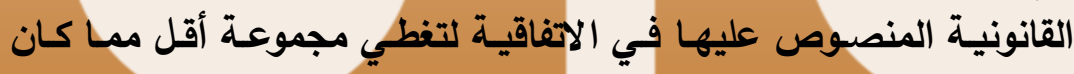

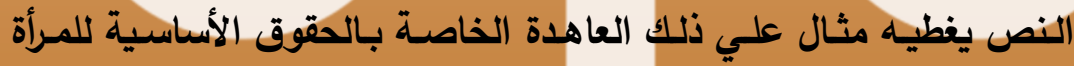

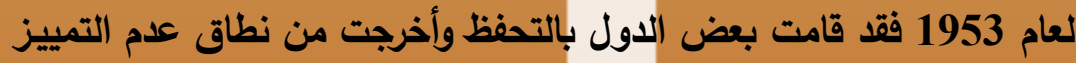

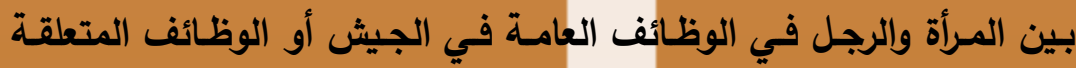

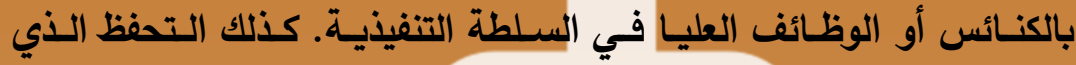

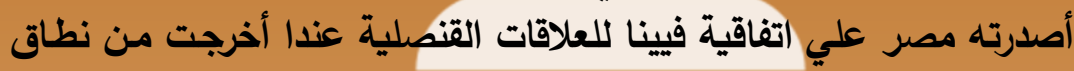

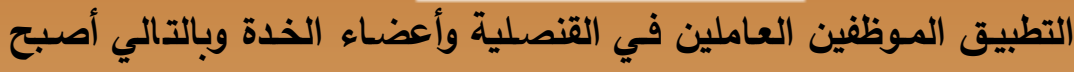

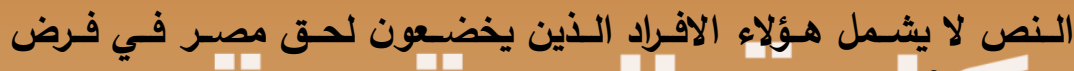

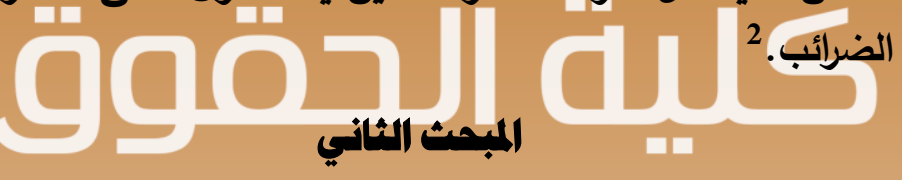

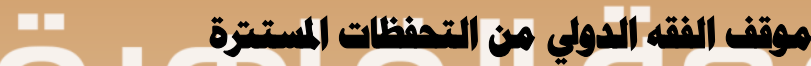

نعرض هنا لموقف الفقه الدولي من التحفظات المستترة ويليه موقف الفقه

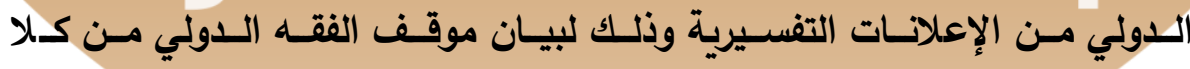

(1) Frank Horn, Reservations and interpretative declarations to multilateral treaties, op. cit.; p. 80-84

(2) Frank Horn, Reservations and interpretative declarations to multilateral treaties, op. cit.; p. 80-83 
المصطلحين وذلك للتعرف علي شروط وملامح كلا منهما.

موقف الفقه الدولى من مصطالح التمفظات المسترة:

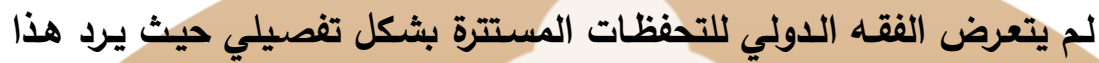

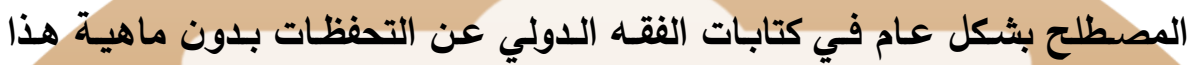
المصطلح وبيان عناصره الرئيسية والاطار القانوني الذي عاتي يحكمه.

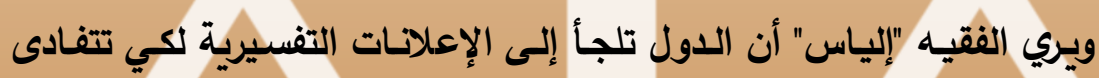

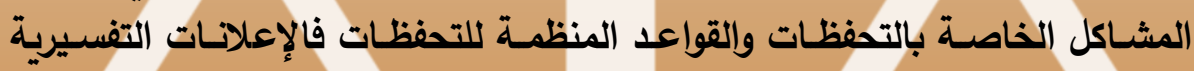

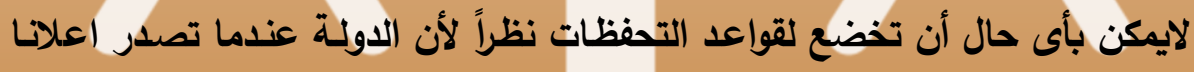

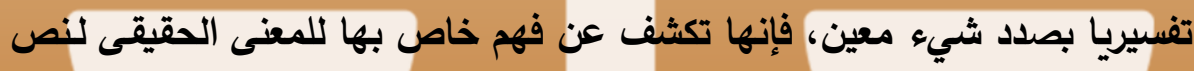

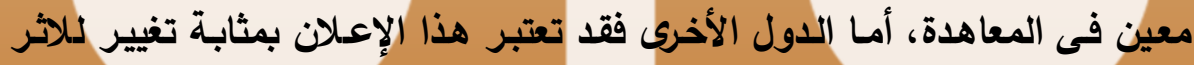
القانوني لبنود المعاهدة، وبالتالي تعد تحفظا مستترا. كمـا أن الفقيـه جـاردينر Gardiner يثير إلى أن التفرقة بين الاعلانـات

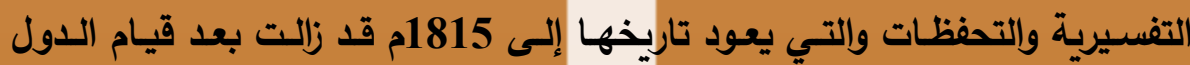

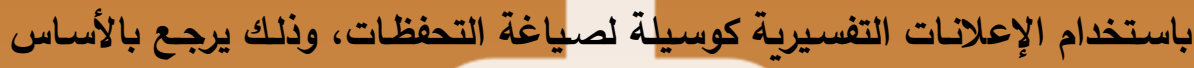

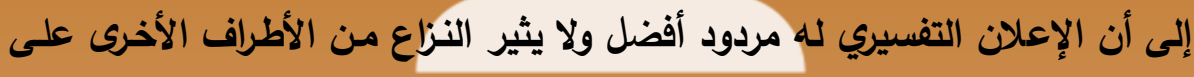

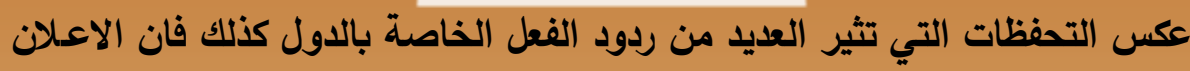

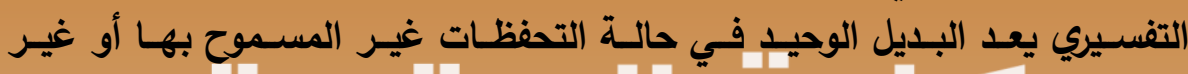

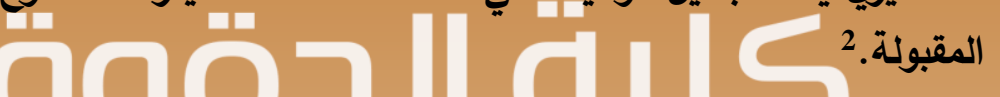

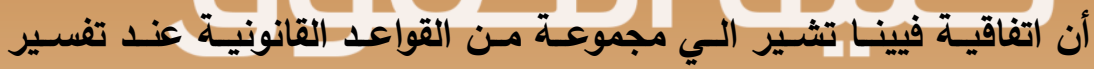

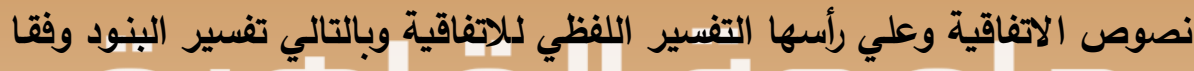

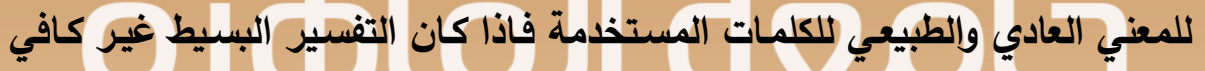

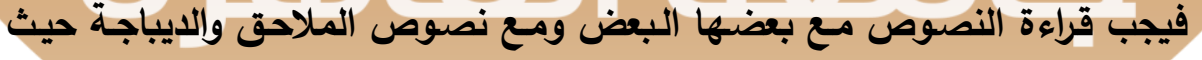

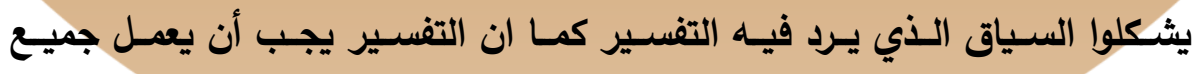

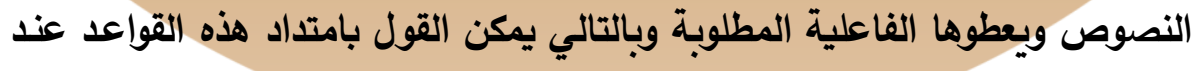

(1) Ibid. at 235.

(2) Richard Gardiner, Treaty interpretation, op. cit., p. 86-88. 
تفسير الإعلانات الصادرة من الدول. 1

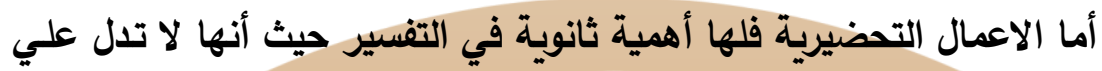

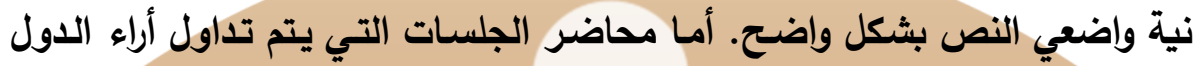

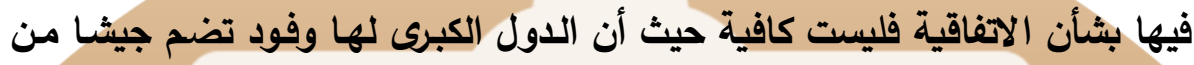

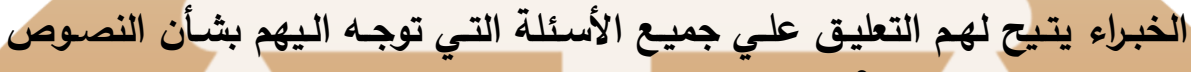
الخلافية في الاتفاقية.

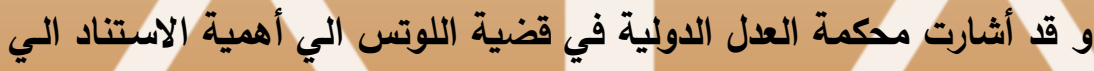

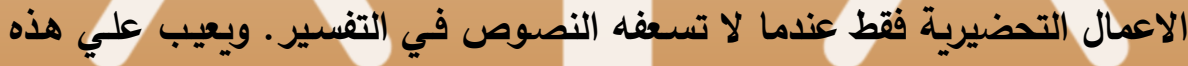

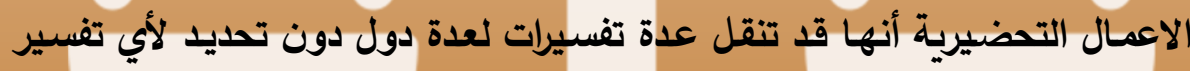

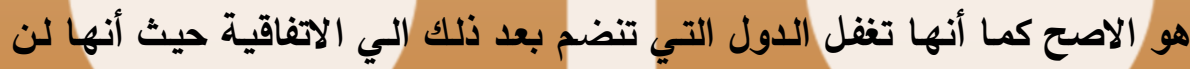
تسجل أي اراء أو تفسيرات لهذه الدول. ونعرض هنا لموقف الفقه الدولي من الإعلانات التفسيرية باعتبار أن هذا المصطلح يختلط بالتحفظات المستترة بشكل كبير. هوقف الفته الدولى من مصطالح الإعلانات التفسيرية:

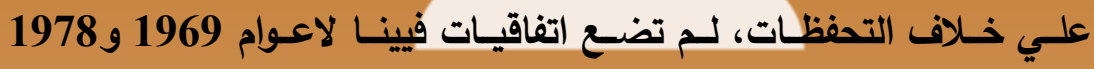

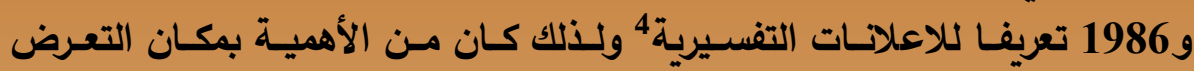

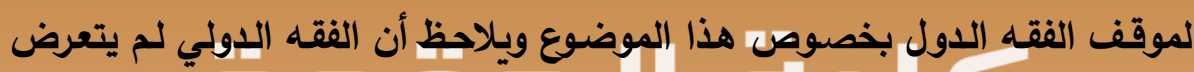

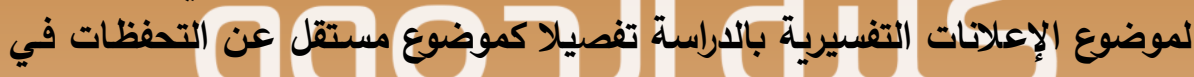

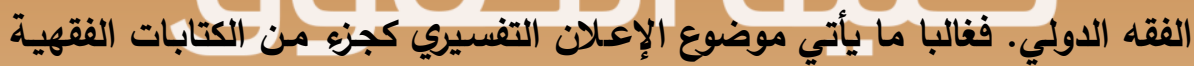

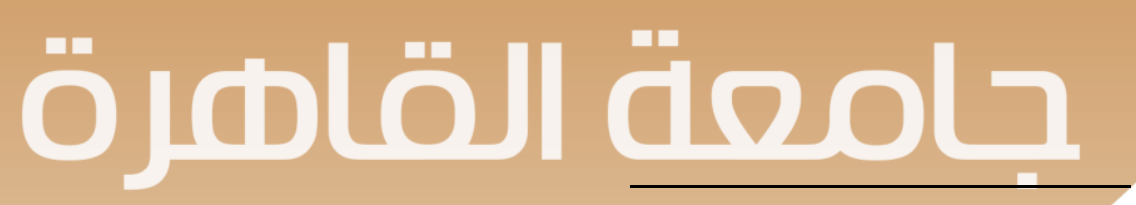

(1) Frank Horn, Reservations and interpretative declarations to multilateral treaties, op. cit.; p. 260-261

(2) Id.

(3) Id.

(4) د. عبد الله المسدي، النظام القانوني للاعلانات التفسيرية الصادرة عن الدول بخصوص المعاهدات الألية، ص 11 (2004) 
التي تتناول التحفظات. 1 إلا أنها يمكن تقسيم موقف الفقه الدولى إزاء الإعلانات التفسيرية إلى فترتين زمنيتين:

الفترة الأولى: وهى الفترة التى سبقت توقيع معاهدة فيينا لعام 1969 (قانون

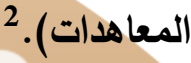

الفترة الثانية: وهى الفترة اللاحقة علي توقيع معاهدة قيينا لعام 1969.3

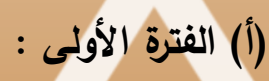

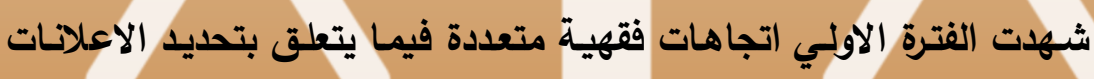

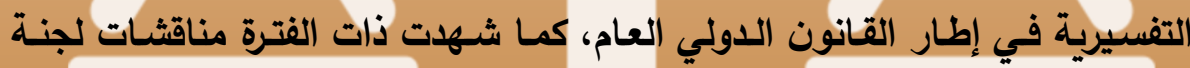

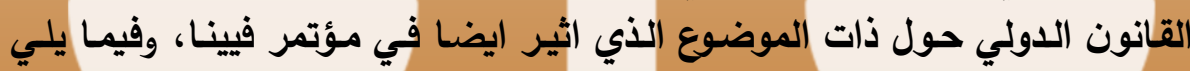

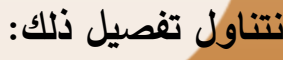

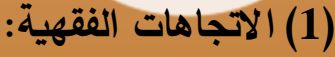

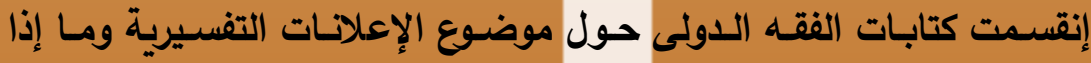
كانت مرادفة للتحفظات أم لا الي ثلاثة اتجاهات التات رئيسية:

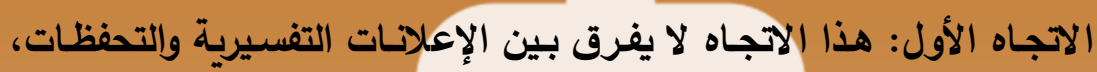

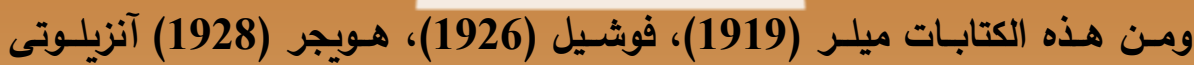

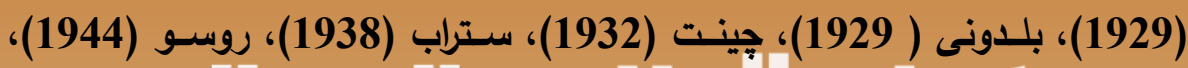

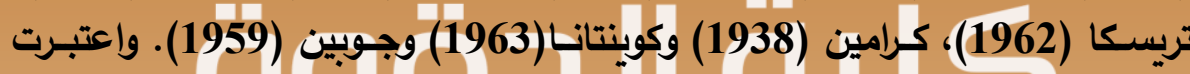

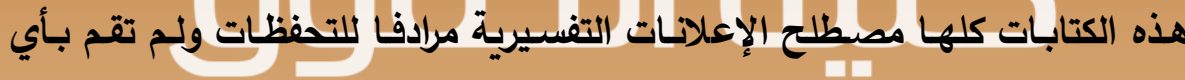

(1) Frank Horn, Reservations and interpretative declarations to multilateral treaties, T.M.C. Asser Institute, the hague, the Netherlands, (1988), p. 236.

(2) See Marjorie Owen, Reservations to multilateral treaties, 38 Yale L.J. 1086 (1928-29).

(3) See Malcolm Shaw, International Law, fifth edition, Cambridge University Press, (2004), p. 822-23 ; See also John king Gamble, Reservations to multilateral treaties: A macroscopic view of state practice, 74 Am. J. Int'l L. 372 (1980). 
اجراء يفرق بين المصطلحين. 1

الاتجــاه الثـاني: يفـرق بـين الإعلاتـات التفسـيرية والتحفظـات ومـن هـذه الكتابـات

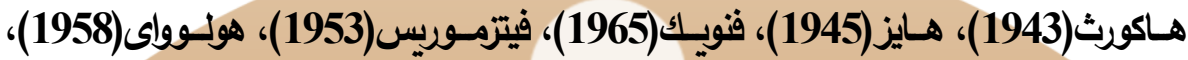

خادجنوري(1953)، بيشوب(1961)، هبيز(194)، فورملى (65-1966) وجيتر (1967). 2

أما الاتجاه الثالث من الفقه الدولي فقد إتخذ موقفاً أكثر اعتدالاً من سـابقيه ولم

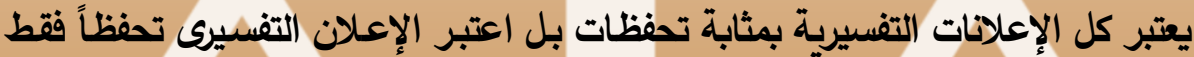

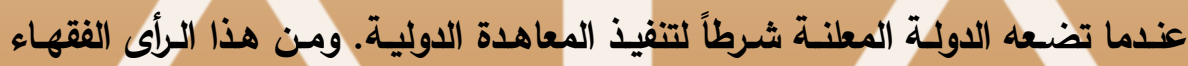
الآتى ذكر أسمائهم: كرامين (1938)، كايلر (1958)، سكيامان (1934). 3

فأوين وهو من أوائـل الكتاب الذين تحدثوا عن الإعلان التفسيري كمفهوم

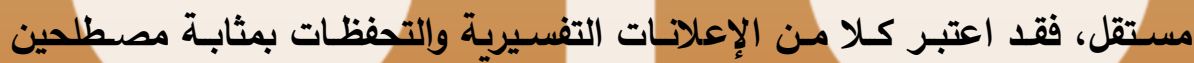

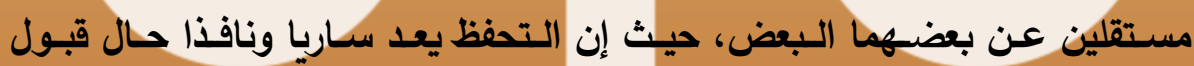

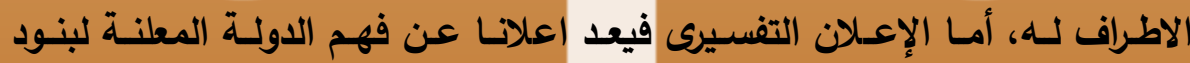

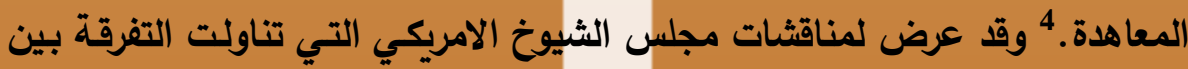

(1) Frank Horn, Reservations and interpretative declarations to multilateral treaties, op. cit., p. 236-237.

(2) G.C. Fitzmaurice, Reservations to multilateral conventions, 2 Int'l \& Comp. L. Q. 1 (1953).

(3) Frank Horn, Reservations and interpretative declarations to multilateral treaties, op. cit., p. 229.

(citing Secretary Hughes who wrote Senator Hale in 1919 if a reservation as a part of the ratification makes a material addition to or substantial change in the proposed treaty, other parties will not be bound unless they assent. But where there is simply a statement of the interpretation placed by the ratifying state upon ambiguios clauses in the treaty, whether or not the statement is called a reservation, the case is really not one of amendment, and acquisence of the other parties to the treaty may be readily inferred unless express objection is made after notice has been received of the ratification with the interpretative statement forming a part of it).

(4) Marjorie Owen, Reservations to multilateral treaties, op. cit., p. 1102 (1928-29). 
الاعلانات والتحفظات. 1 أما كل من فسليوف ورودا فقد اعتبرا الإعلانات التفسيرية

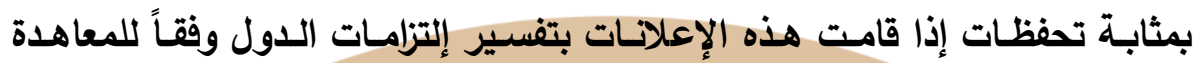

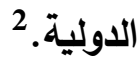

امسا مسودة هارقارد لعام 1935 فقد اعتبرت الإعلانـات التفسيرية بمثابـة

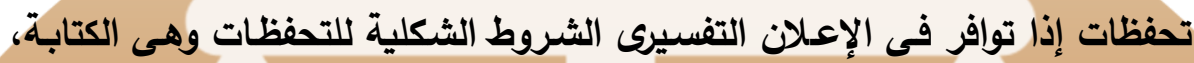

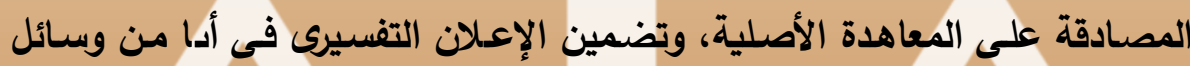
التصديق أو القبول.

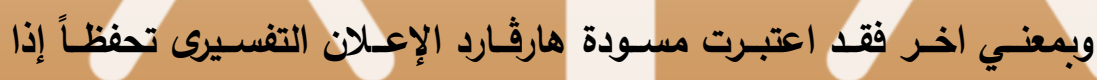

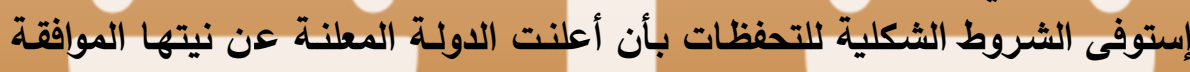
على المعاهدة بشرط أن يعطى الإعلان تفسيراً معيناً.

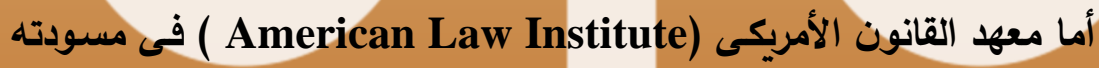

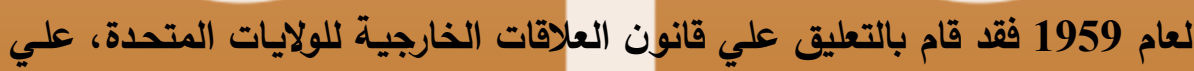

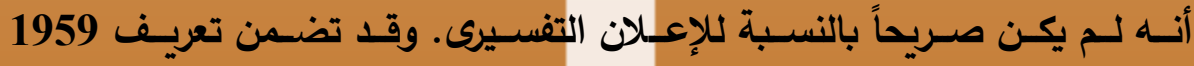

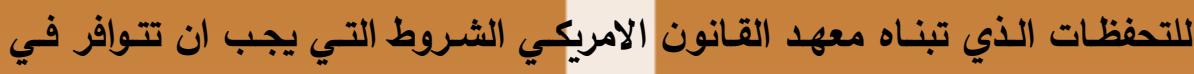
التحفظات وهي الاتي: التئاه 1- أن يغير من الأثر القانوني المعاهدة.

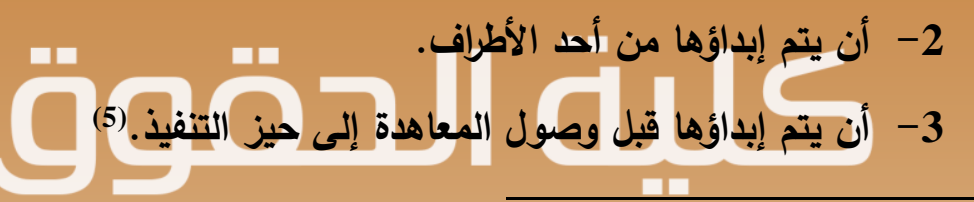

(1)Frank Horn, Reservations and interpretative declarations to multilateral treaties, op. cit., p. 1102-1104.

(2) Ibid. p. 229.

(3) citing).lbid Harvard draft, p. 860-861).

(4) American Law Institute ALI, Tentative draft (1959) III, defined at 57.

(5) ALI, Tentative draft (1959) \$111, defined at 57, p13. "A reservation is a qualification by a party of its assent to an international agreement, made before the agreement becomes binding upon that party, and intended to change its legal effect".(emphasis added). ALI, Tentative draft (1959) \$ 111, defined at 57, p13 
وفى تعريـف أكثر إتسـاعاً شـمل بعض التغييـرات فـى الصـياغة وذلك في

التقرير النهائي قامت بتعريف التحفظ علي أنه تصريت أو علان رسمي تصدره دولة أتئة

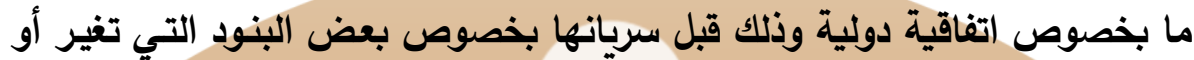
تحدد الأثر القانوني للاتفاقية. 1 و لذلك فأن معه القانون الأمريكى قد ضم الإعلانات التفسيرية فى مفهوم

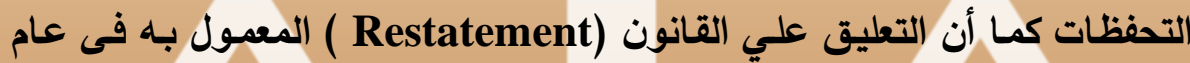

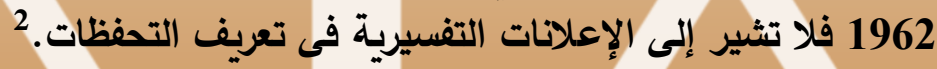
وقد علق معهد القانون الأمربكى على هذا التعريـف بإنـه لايضـم الإعلان التفسيرى أو التفاهم التفسيرى فى التعريف. 3 (2) مناقثات لجنة القانون الدولى:

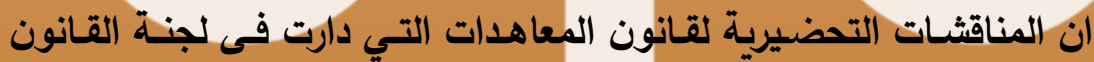

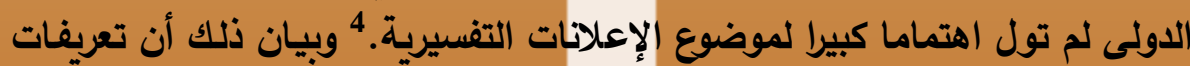

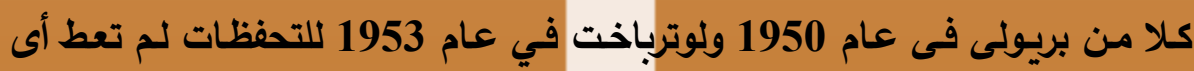

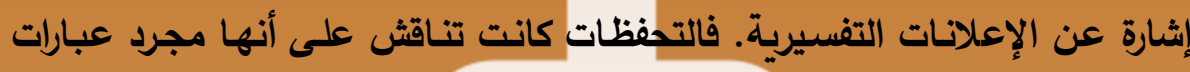

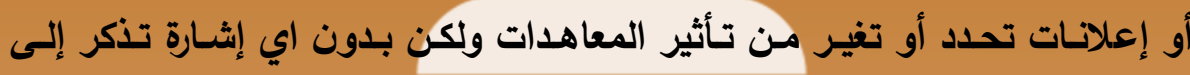

(1) "A reservation is a formal declaration by a state made before an international agreement becomes binding upon it except upon terms that it regards as changing or stating more precisely the legal effect of the agreement ".(emphasis added ). Loc. Cit.

(2) "A reservation is a formal declaration made by a sigratory before it becomes bound by an international agreement, that the agreement will not he binding upon it except upon terms that it regards as changing the effect of the agreement under international law" (emphais adeded). Loc. Cit.

(3) Frank Horn, Reservations and interpretative declarations to multilateral treaties, op. cit., p. 229. (citing ALI, of final draft, 1959 \$ 111, defined at 57 and ALI, Restatement 1965, p. 391 \$ 127).

(4) Ibid. p. 123-127. 


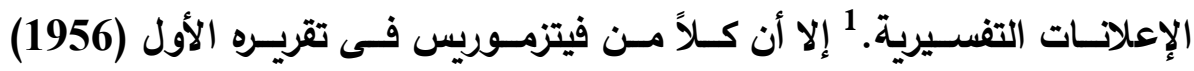

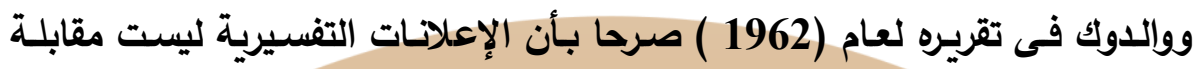

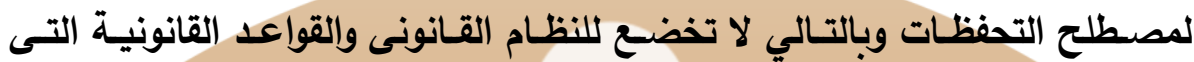
تحكمها.2 - (20)

وقدا أبـدى فيتزمسوريس هذا الـرأي الخـاص بعدام انطبـاق النظـام القـانوني

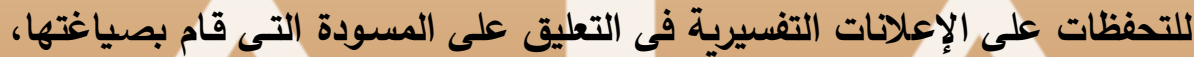

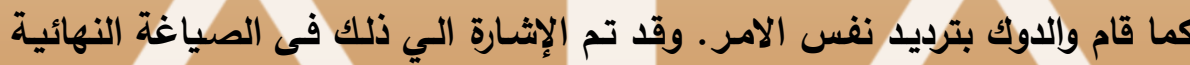

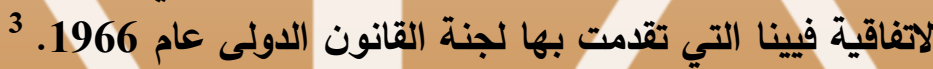

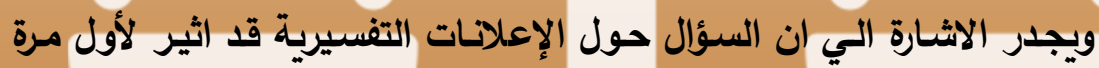

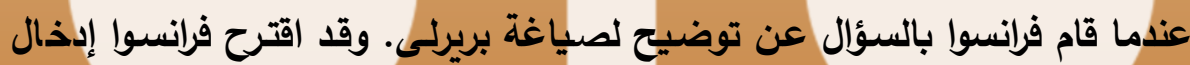

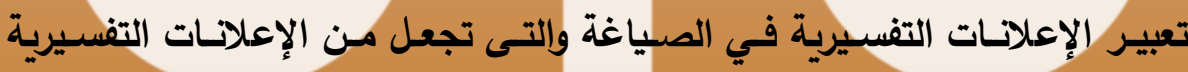

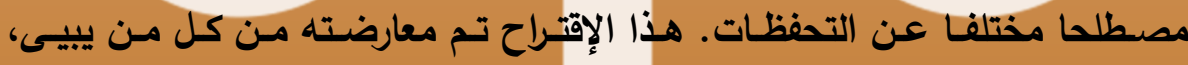
هاسون وسبيريولس.

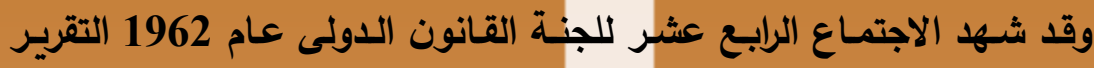

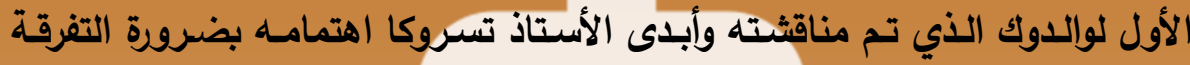

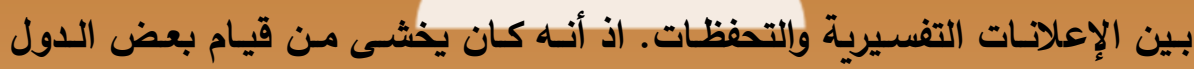

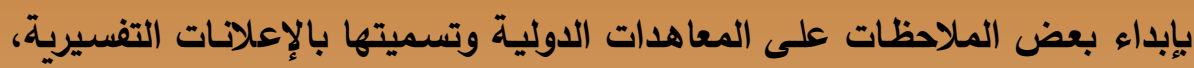

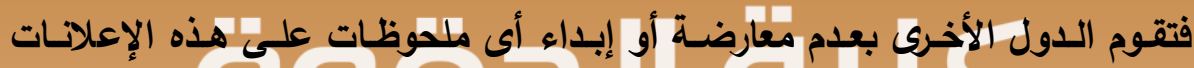

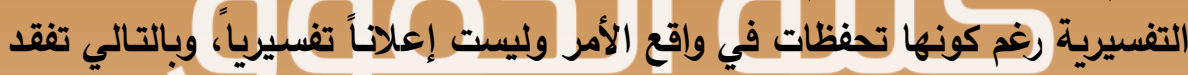

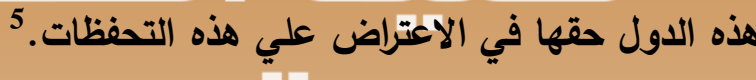

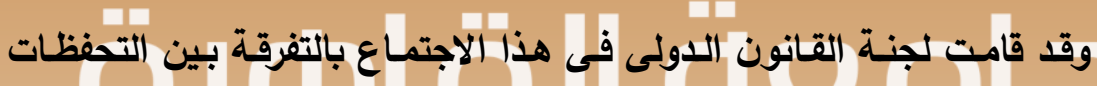

(1) ILCYB 1953 p. 123.

(2) ILCYB 1956: II, p. 110 (art. 13) and p. 126; ILCYB 1962: II, p. 31-32 (Fitzmaurice report mentioned in 1956 and Waldock's in 1962).

(3) ILCYB 1951: I, p. 171-172.

(4) UN Doc. A/5209, ILCYB 1962:II, p. 163.

(5) ILCYB 1965: II, p. 46-47 
والإعلانات التفسيرية وأدخلت هذه التفرقة فى تقريرها الـي الجمعية العامسة للأمم

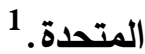

وقد لخصت اللجنة موقفها من الإعلانات التفسيرية بقولها إن الدول عندما

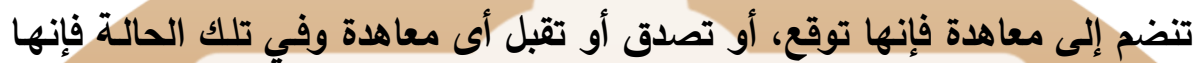

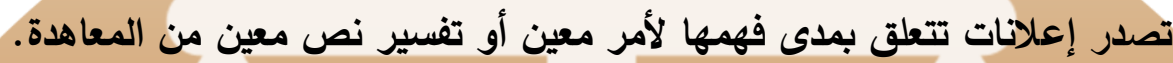

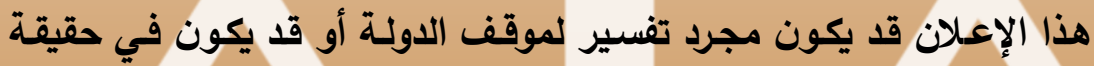

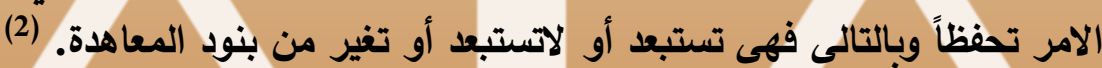

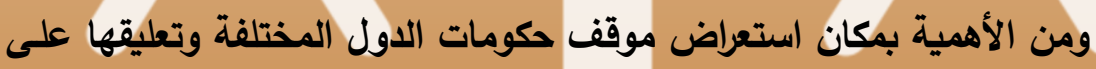

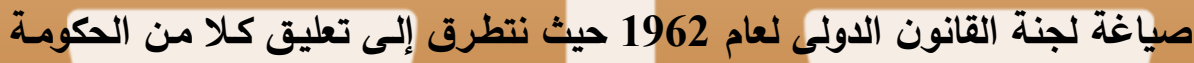

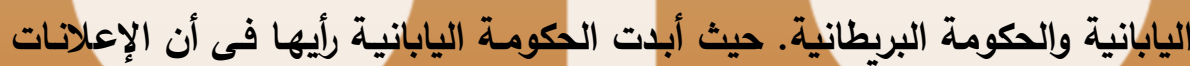

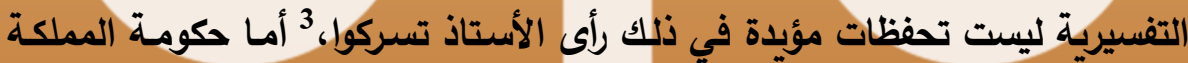

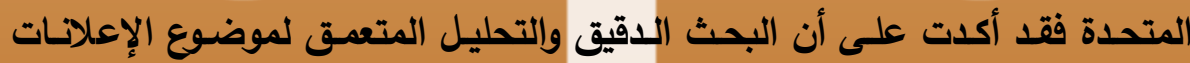

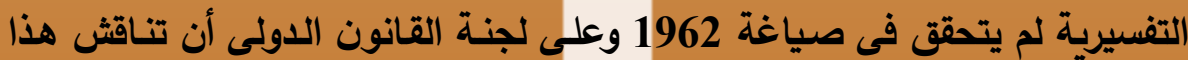
الموضوع فى فترة لاحقة بثكل اكثر تفصيلا.

وقد رد المقرر الخاص للجنة على التعليقين الخاصين بالسكومتيين اليابانية

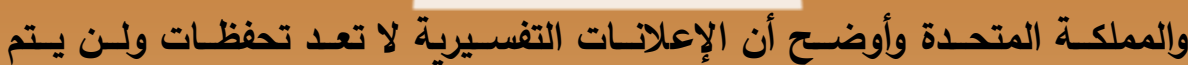

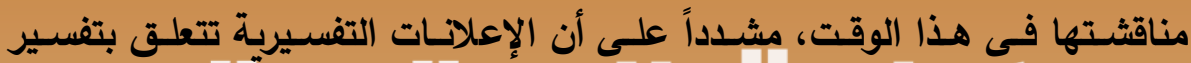

(1) Loc. Cit.

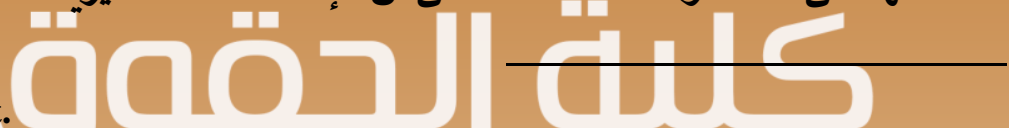

(2)"The need for this definition arises from the fact that states, when singing ratifying, acceding to, accepting on approving a treaty, not infrequently make declarations as to their understanding of some matter or as to their interpretation of a particular provision. Such declaration may be a mere clarification of the state's position or it may amount to a reservation according as it does or does not vary or exclude the application of the terms of the treaty as adopted." (emphasis added). United Nations Conference on the law of treaties, documents of the conference, A/CONF. 39/11 Add.2,p.10, para.11.

(3) ILCYB 1965, II, page 46-47.

(4) Loc. Cit. 
المعاهدة وليس تنفيذها. وبالتالى تخضع الإعلانات التفسيرية لنطاق تطبيق المواد

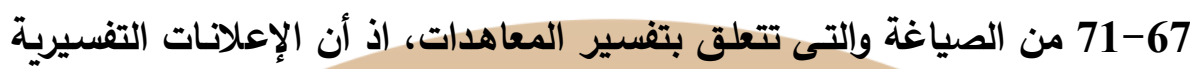

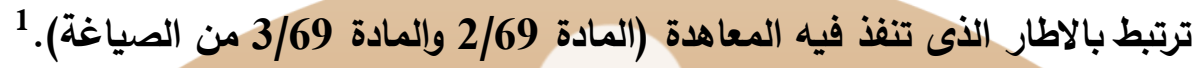

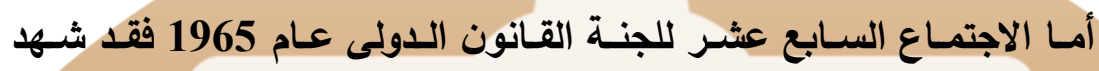

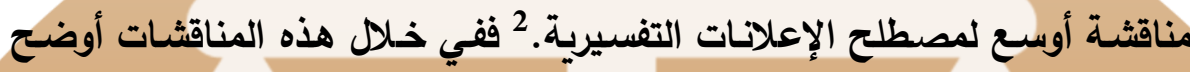

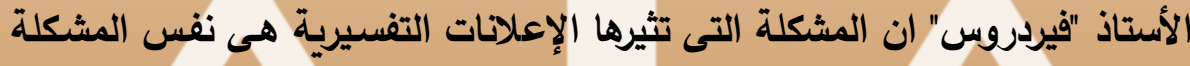

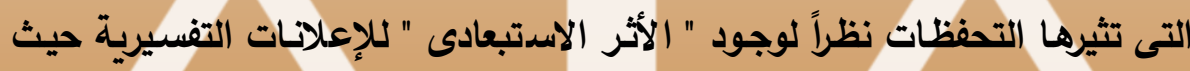

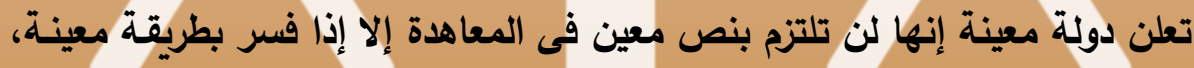

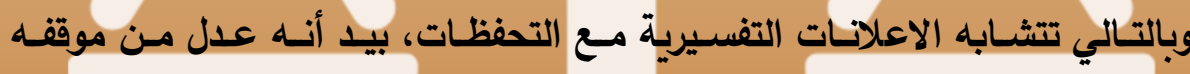

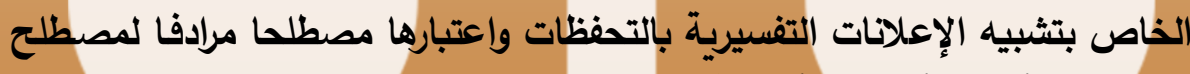

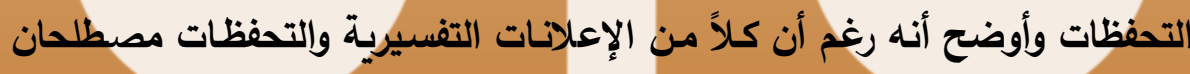
مختلفان إلا إنه لظروف وأسباب عملية فإن القواعد أندات التى تنطبق عليهما وإحدة. 3

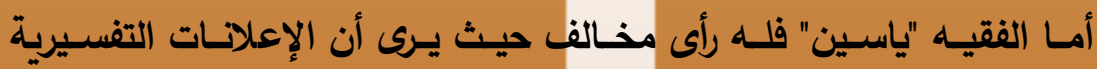

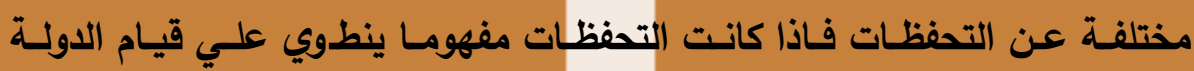

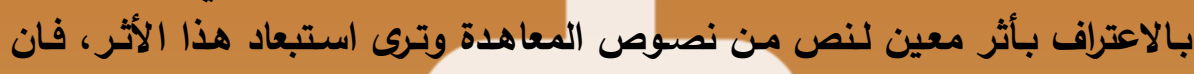

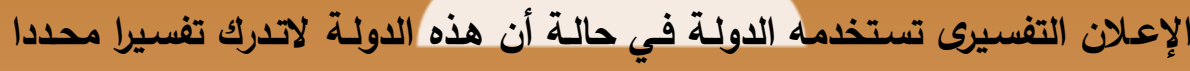

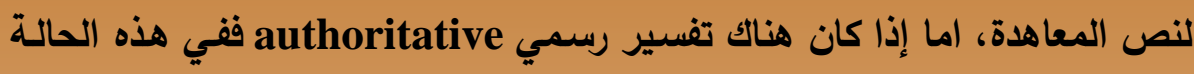

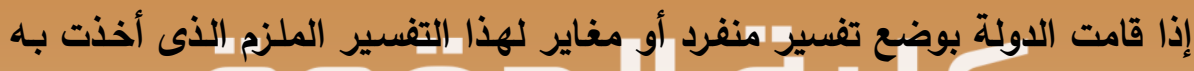

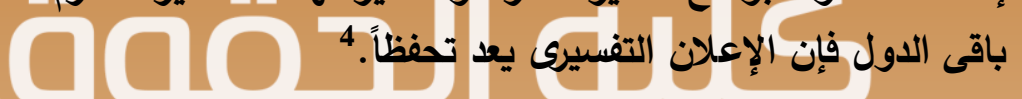

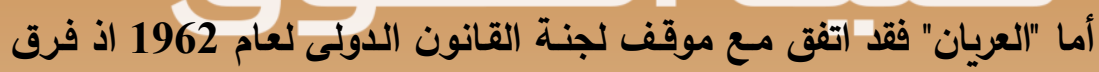

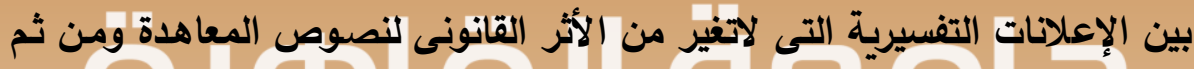

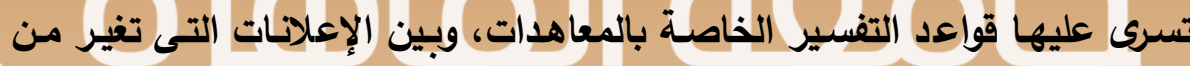

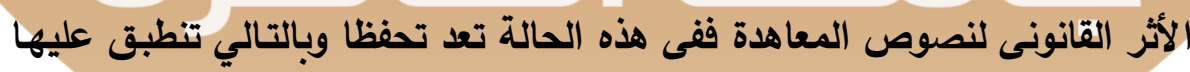

(1) Loc. Cit.

(2) Ibid. p. 153.

(3) ILCYB: 1965: I, p. 46-47.

(4) Loc. cit. 


\section{قواعد التحفظاتًّ.}

أما كل من "أجو وكاسترين" فقد اتفقا مـع "واللدوك"، حيث إن كـلاً منهمـا قد

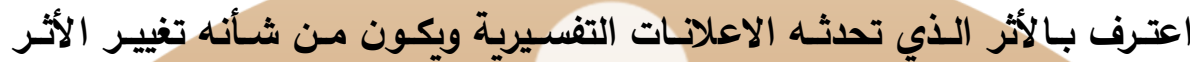
القانوني لنصوص المعاهدة وصعوبة التمييز بينها وبين التحفظات، نظرا لأن كـلا

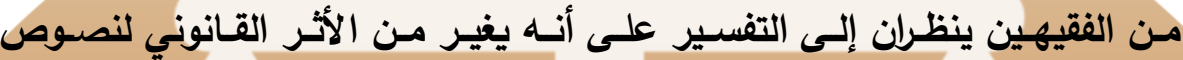

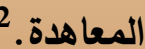

\section{(3) (3) مناقشات مؤتمر قيينا:}

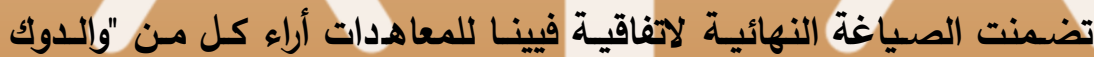

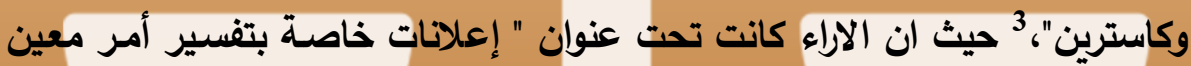

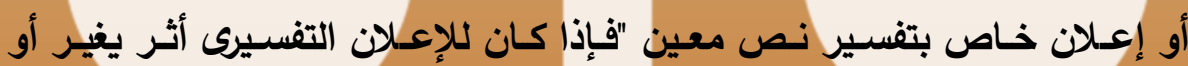
يستبعد تطبيق بنود المعاهدة فيعتبر تحفظاً. 4 وقد قام وفد المجر بتقديم اقتراح لتعديل صياغة المادة الأولى والتى تضمنت

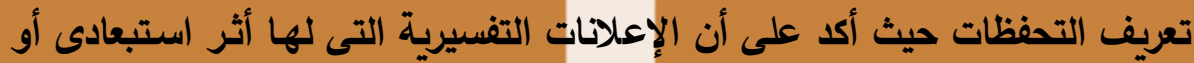

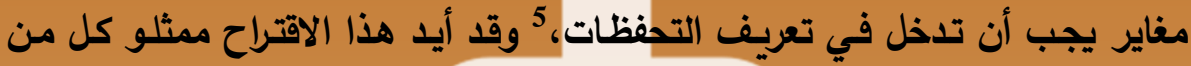

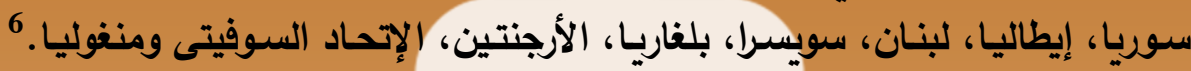

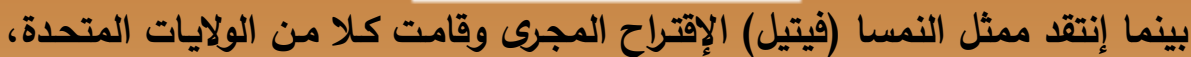

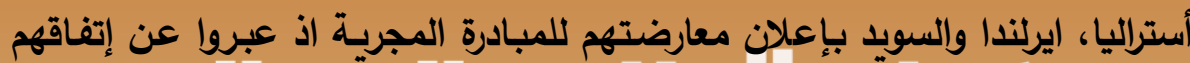

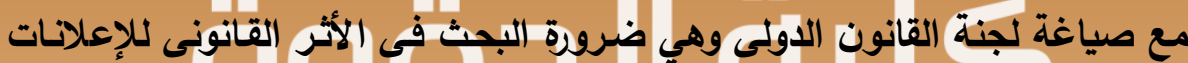

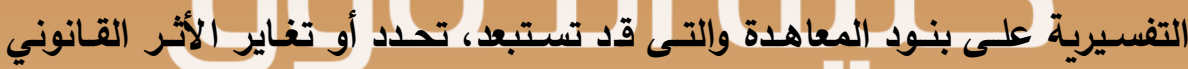

(1) Ibid, p. 153.

(2) Ibid, p. 166.

(3) Frank Horn, Reservations and interpretative declarations to multilateral treaties, op. cit., p. 5 (citing Vienna Conference, Doc. P. 10).

(4) J.M. Ruda, Reservations to treaties, p. 106 (Recueil des cours) 1975 III/Tome 146.

(5) Loc. Cit.

(6) Frank Horn, Reservations and interpretative declarations to multilateral treaties, op. cit., p. 232-233. 
للمعاهدة قبل اعتبارها تحفظات.

وقد أعطى "والدوك" الأي شغل منصب المقرر الخاص للجنة القانون الدولي

بعض الأمثلة للإعلانات التفسيرية، وهى الاعلانات التي تستهدف تحقيق الاتهي الاتي:

(1) إعلان ذو طبيعة عامة ويستهذف التفسير الرسمي لمعني الاتفاقية.

(2) إعلان يستهزف توضيح بعض البنود الغامضة.

(3) إعلان يستهذف توضيح معنى البند الذي يثير بعض المشاكل.

(4) إعلانات مرتبطة بتطبيق المعاهدة في بعض الحالات.2

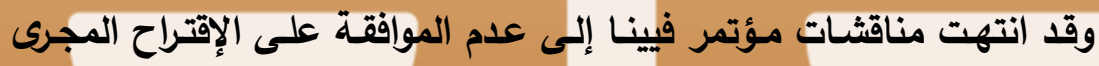

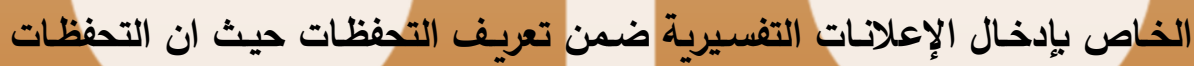

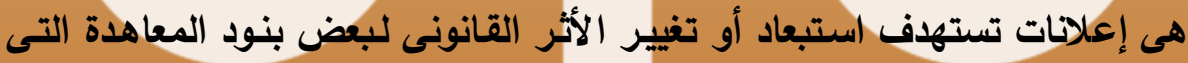

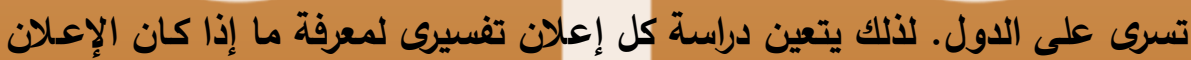

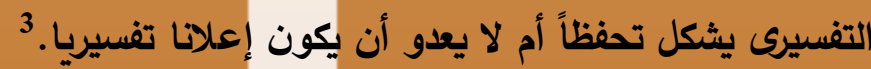

و بإستعراض تاريخ جسات ومناقشات لجنـة القانون الدولى وتاريخ صياغة

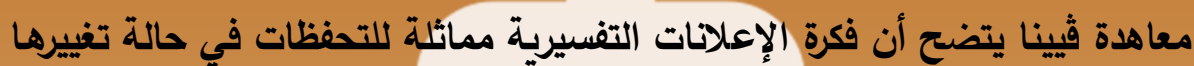

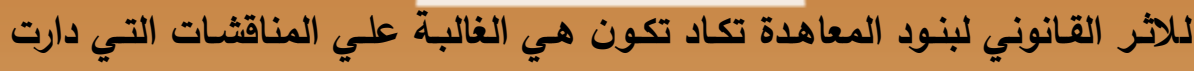

(1) Loc. Cit.

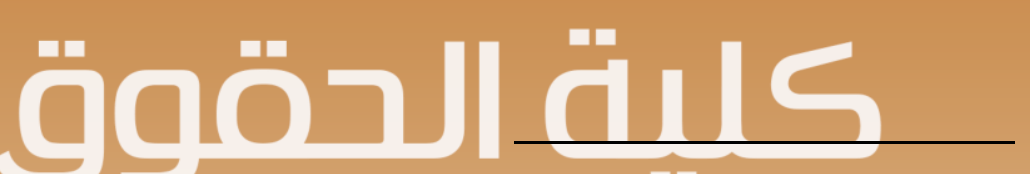

(2) (a) " Were of a general nature and represented an objective interpretation of what was understood to be the meaning of the treaties".

(b) Had the "purpose to clarify the meaning of doubtful clauses"

(c) Had the "purpose to clarify the meaning of clauses which were controversial for particular states"

(d) "Dealt with the application of a treaty in certain circumstances peculiar to a state."

(3) ILCYB 1965: I, p. 162); see also J.M. Ruda, Reservations to treaties, op. cit., p. 106. 


\section{قيل توقيع اتفاقية فيينا لعام 1969. 1}

و يمكن القول بأن المناقشـات الفقهية في مرحلة مـا قبل معاهدة فيينا لعام

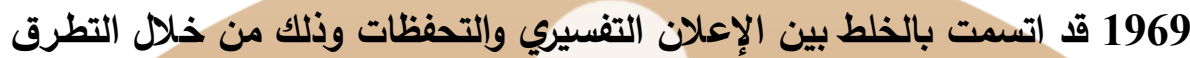

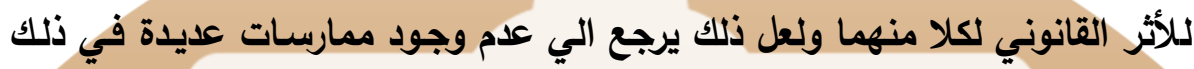

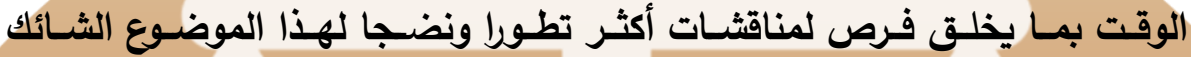
وتأرجصت الآراء ما بين اتجاهات ثلاثنة كما سبق شرحها.

(ب) الفترة الثانية: وهى الفترة اللاحقة علي توقيع معاهدة ثيينا لعام 1969

أمـا الفقـه الـدولي المعاصر فقـد واجـه ذات المشكلة الخاصـة بدراسـة مـا إذا

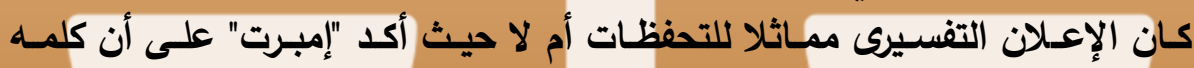

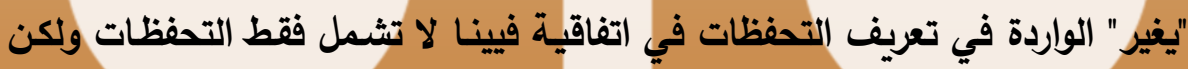

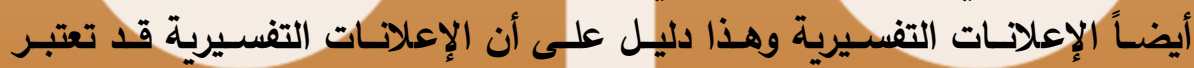

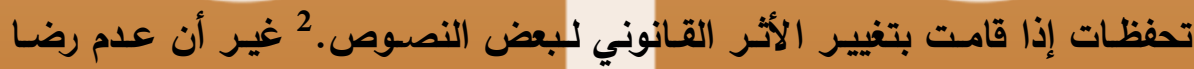

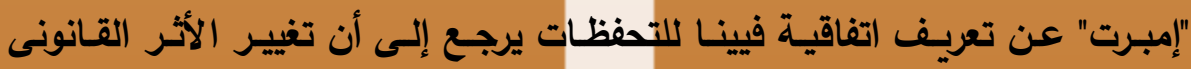

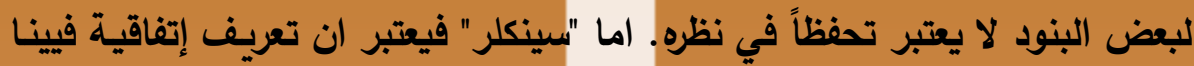

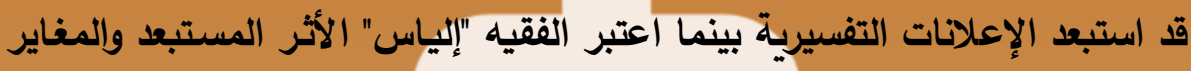
لنصوص المعاهدة هو من العناصر الأساسية التى تُعرّف وتحدد التحفظات. 3

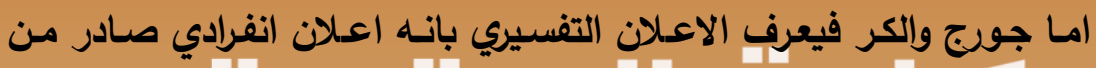

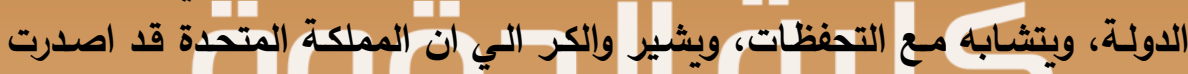

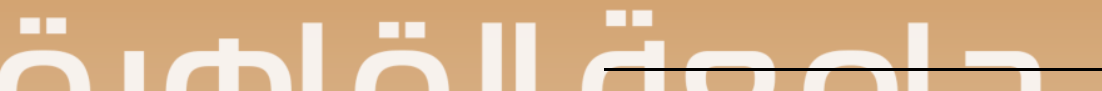

(1) Frank Horn, Reservations and interpretative declarations to multilateral treaties, op. cit., p. 234.

(2) Loc. Cit.; See also Ian Sinclair, The Vienna convention on the law of treaties, Manchester University Press, at 52 (United Kingdom) (1966) (on the basis of this distinction, a qualified interpretative declaration should be treated as reservations).

(3) Frank Horn, Reservations and interpretative declarations to multilateral treaties, op. cit., p. 234 (citing Imbert, Reserves). 
اول اعلان تفسيري بعد مؤتمر فيينا لعام 1815.

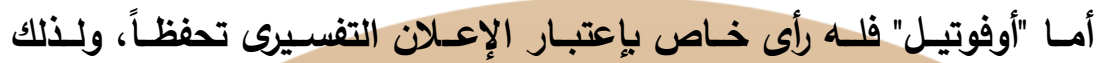

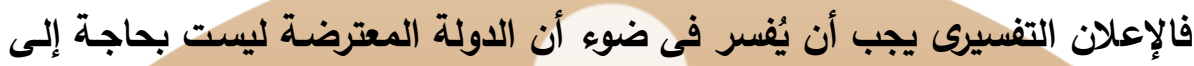

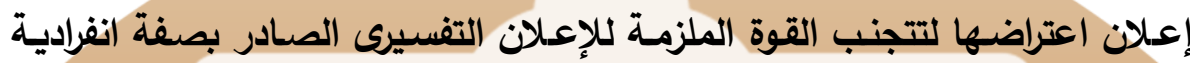
من إحدى الدول.

أمـا "تومسكان" فيتفق مـع "فيدروس" في أن الإعلان التفسيرى يضـم كافـة

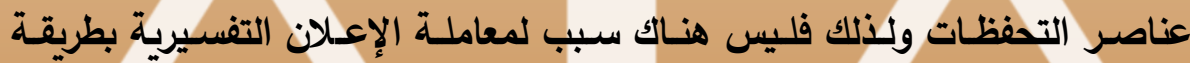
مختلفة عن التحفظات.

و قد اختلف فقهاء القانون اللدولى حول معنى الإعلانات التفسيرية وأعطي

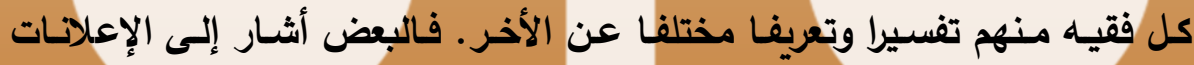

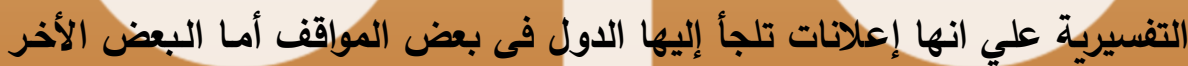

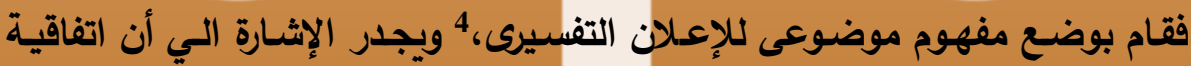

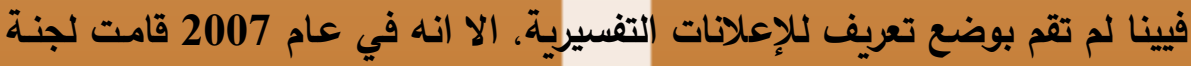

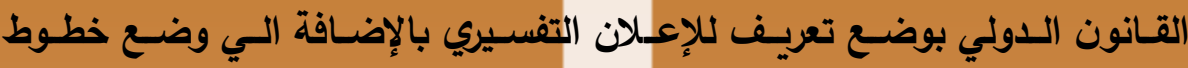
عربضة للتحفظات.

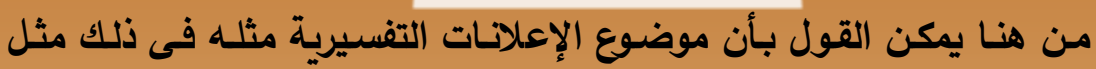

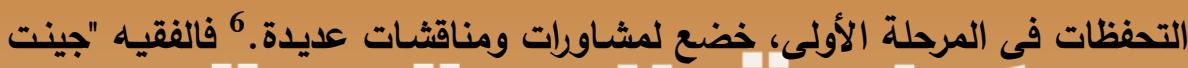

(1) George K. Walker, Professional's definitions and state's interpretative declarations (understandings, statements, or declarations) for the 1982 law of the Sea convention, 21 Emory Int'l L. Rev. 507 (2008).

(2) Frank Horn, Reservations and interpretative declarations to multilateral treaties, op. cit., p. 235.

(3) Loc. cit.

(4) ILC Report, fifty-ninth session (7 May - 5 June \& 9 July to August 2007)

(5) Richard Gardiner, Treaty interpretation, Oxford university press, Oxford, (2008) p. 86

(6) General Assembly official records, sixty-second session, supplement no. $10(\mathrm{~A} / \mathbf{6 2} / \mathbf{1 0})$. 
" -علي سبيل المثال - أشار إلى التحفظات على أنها تلك الإعلانات التى تصدرها

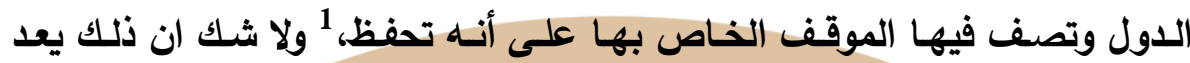
تطبيقا للمعيار الثكلي في تحديد طبيعة الاعلان التفسيري الذي يعتمد لارجهة كبيرة

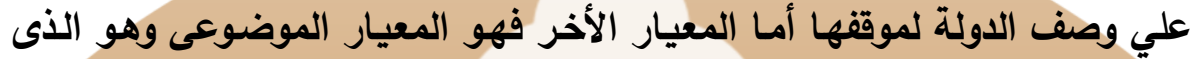

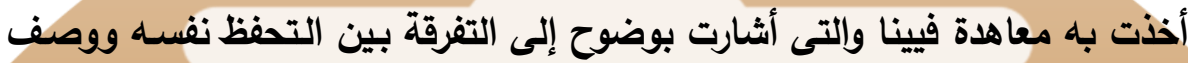

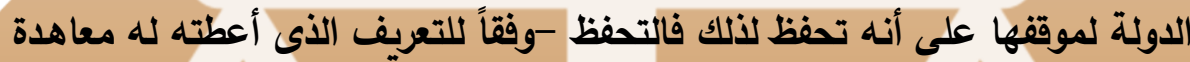

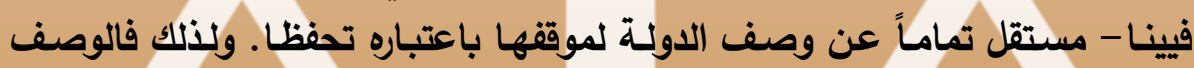

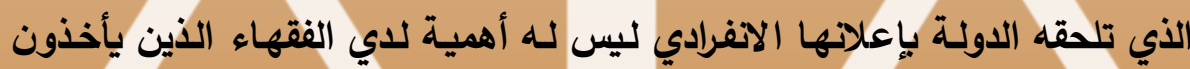
بالمعيار الموضوعي في تحديد طبيعة الاعلان. وقد عرف الفقيه McRae الإعلان التفسيري بأنسه أي إعلان تصدره الدولة

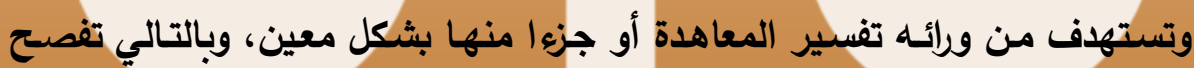

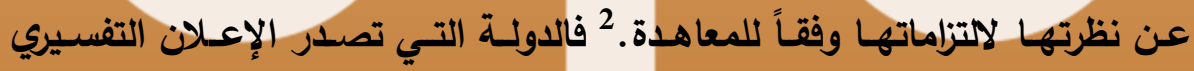

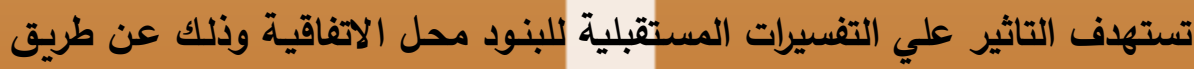

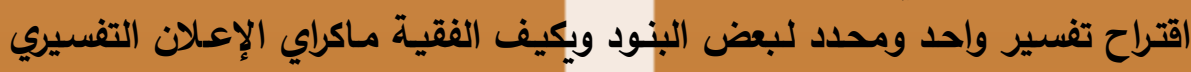
بأنه ايجاب بتفسير محدد ولكنه يفتقر الي أي صيغة الزامية. 3

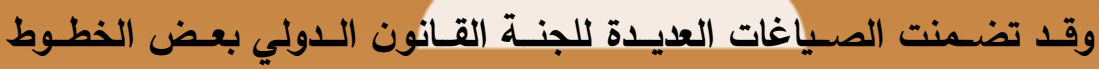

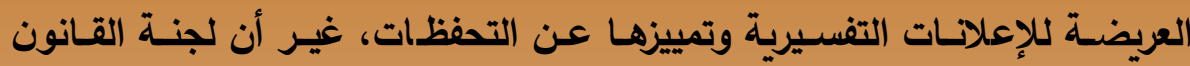

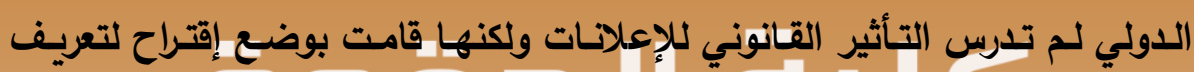

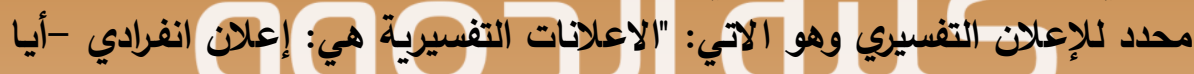

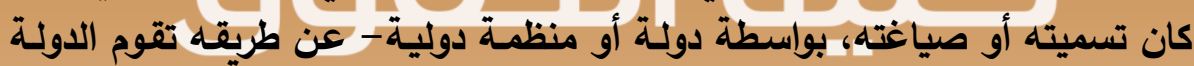

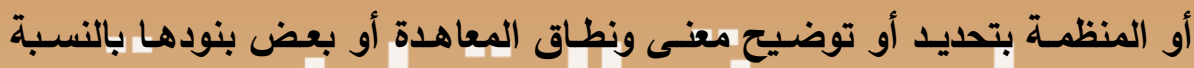

(1) Frank Horn, Reservations and interpretative declarations to multilateral treaties, op. cit., p. 235

(2) McRae, The legal effect of interpretative declarations, 49 Brit. Y.B. Int'L. L. 29 (1979).

(3) L.D.M. Nelson, Declartions, Statements and Disguised Reservations with respect to the Convention on the Law of the Sea, International and Comparative Law Quarterly, Vol. 50 p. 775. 
ل اللاولة المعلنة.

ويمكن القول بأن الإعلانات التفسيرية قد يتم إعلانها في أي وقت، علي

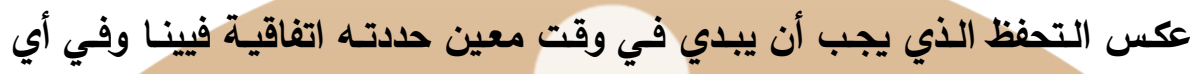

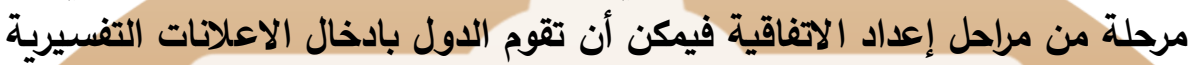

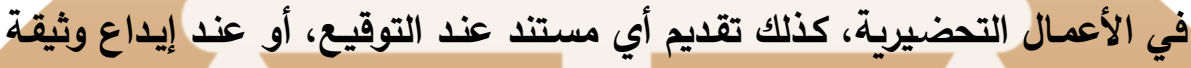

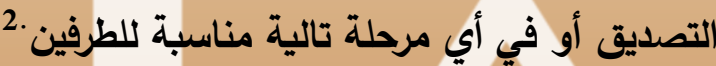

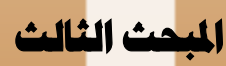

\section{إبكالية التفرقة بين التمنظات المتترة والإعلانات التفيرية}

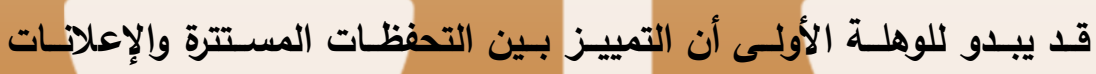

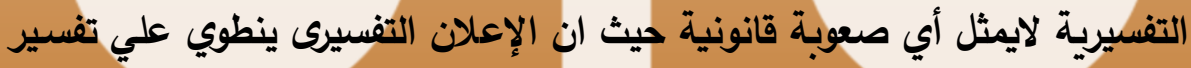

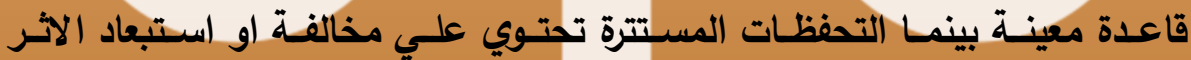

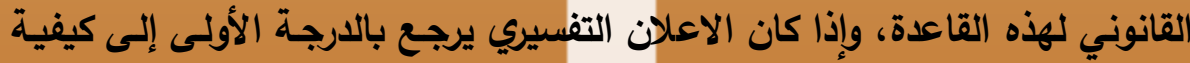

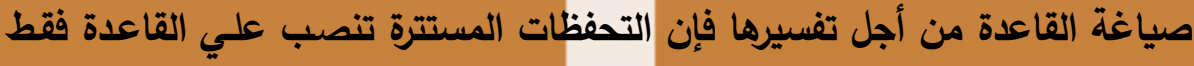

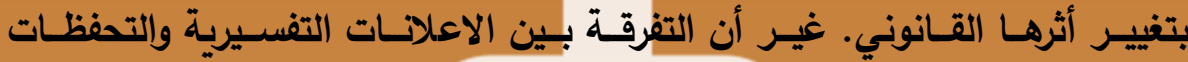

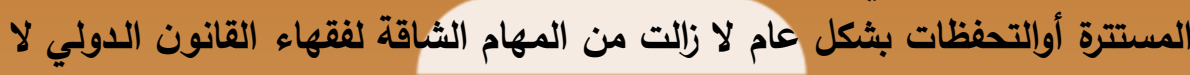

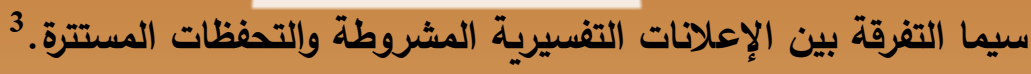

(1) ILC's proposed definition is "Interpretative declaration means "a unilateral statement, however phrased or named, made by a state or by an international organization whereby that state or that organization purports to specify or clarify the meaning or scope attributed by the declarant to a treaty or to certain of its provisions". Report of ILC, fftyninth session (7 May- 5 June- Aug 2007), General Assembly official records, sixty second session, supplement no. 10 (A/62/10) chapter IV p. 48.

(2) Fourth report on law of treaties, by Waldock, 1965, Yearbook of the ILC, vol. II, p. 49, para. 2.

(3) G.C. Fitzmaurice, Reservations to multilateral conventions, op. cit., p. 141-42 (The ILC found the following problems the most difficult the 
ولا شك أن هذا البحث يتعدي مجرد الإشارة الي أن الإعلان التفسيري يختلف

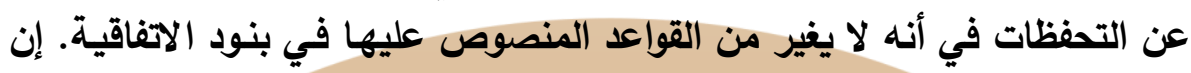

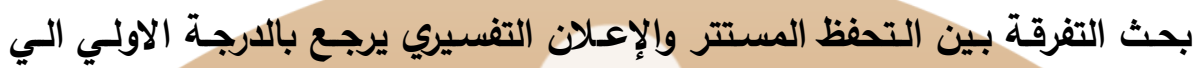

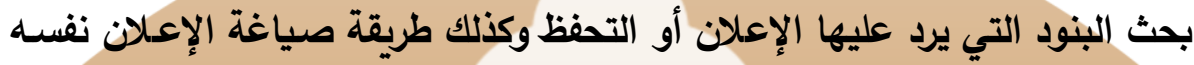
وذلك من أجل الوصول الي تكييف سليم للاعلان. والطريقة التى يمكن أن نتبعها من أجل إجراء التمييز بين الإعلان التفسيرى

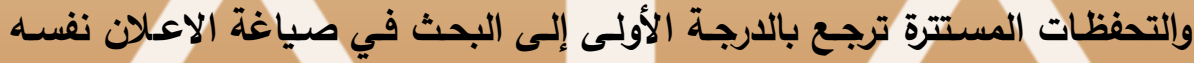

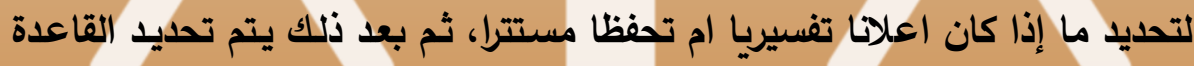

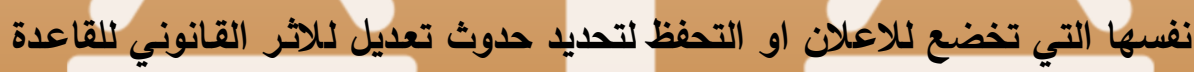

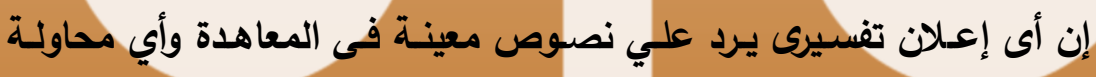

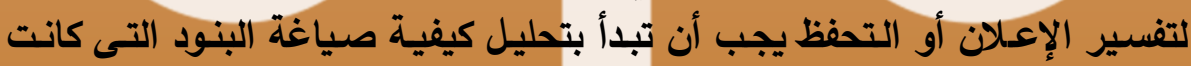

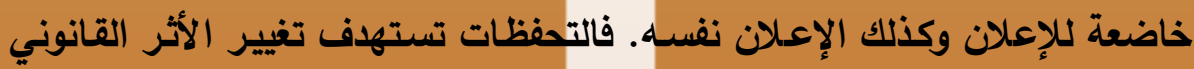

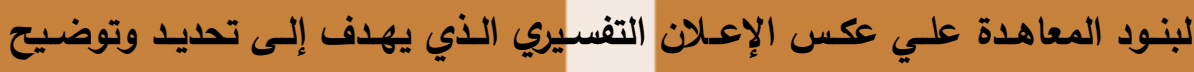

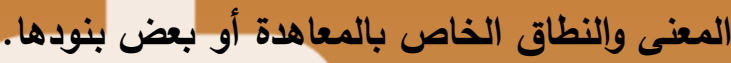
ويشير الفقيه جاردينر Gardiner إلى أن التحفظ يغير من آثار المعاهدة

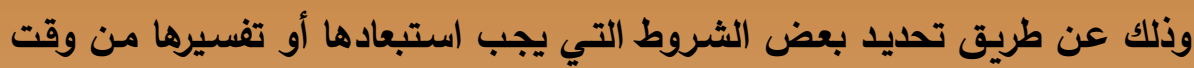

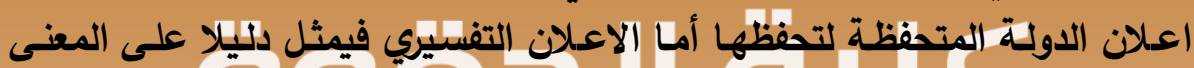

الذي تعطيه الدولة المعلة لبعض بنود المعاهدة وإلتي تفههها على هذا النحو. 1 غير أن التفرقة بين التحفظات والإعلانات التفسيرية ترجع إلى القرن السابع

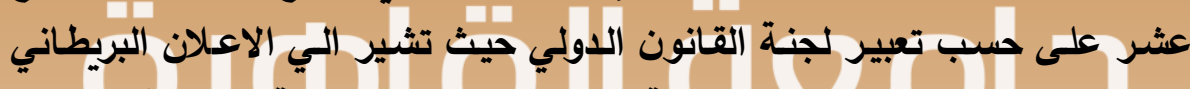
عند استبدال بعض المذكرات الخاصـة بالتصديق على الاتفاقية التي وافتق عليها

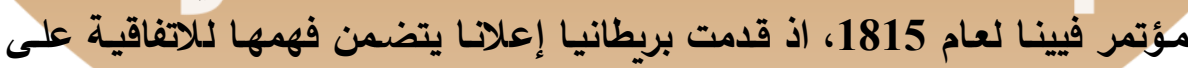

question of the very definition of reservations, the legal regime governing interpretative declarations).

(1) Richard Gardiner, Treaty interpretation, Oxford university press, Oxford, (2008), p. 86-88. 
أنها التزام لاتهاء العمل على هزيمة نابليون ولكن لا تثكل إجبارا أو فرضـا لحكومـة معينة على فرنسا.1

ويشـيز جـاردينر Gardiner إلـى أن التفرقـة بـين الاعلاتكات التفسيرية

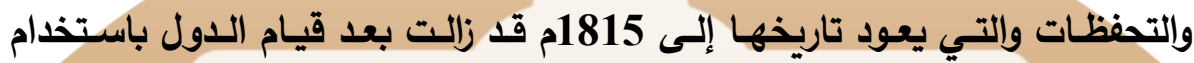

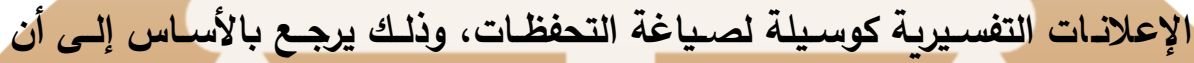

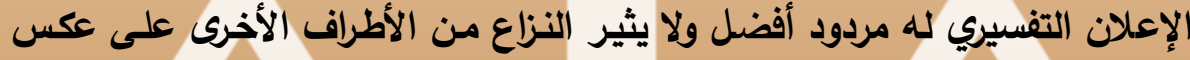

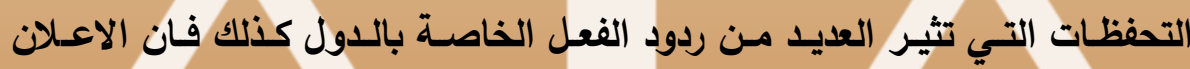

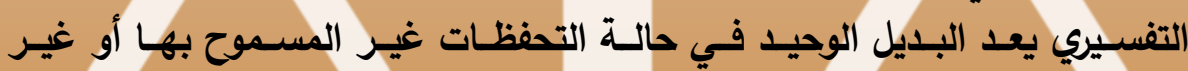

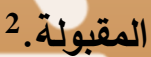

ولا شك أن كلاً من الإعلانات التفسيرية وإلتحفظات إعلانات انفرادية حيث

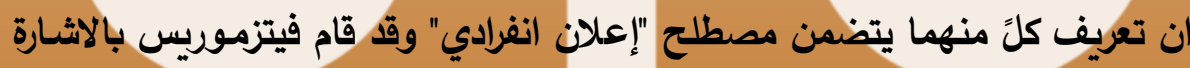

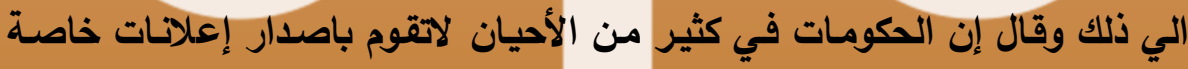

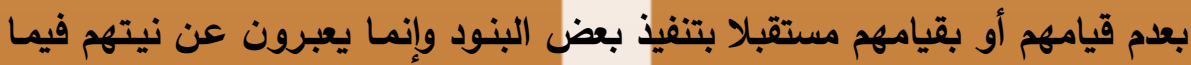

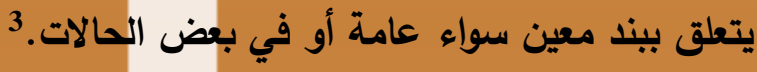

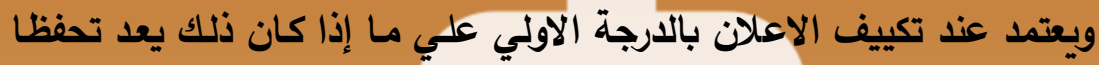

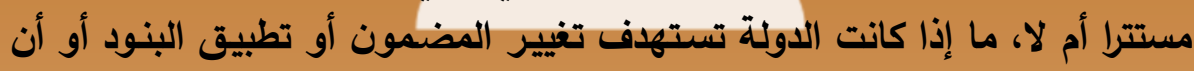

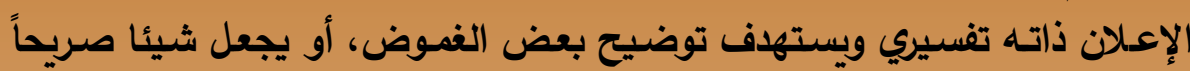

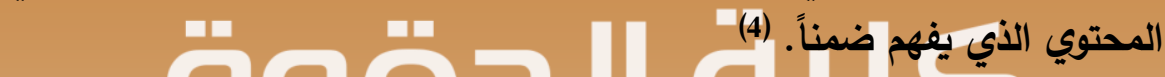

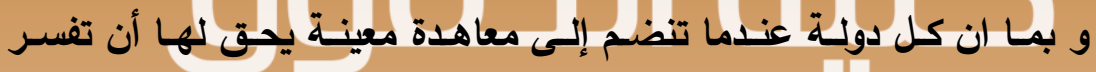

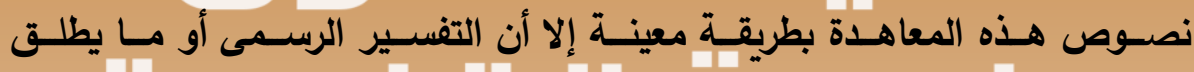

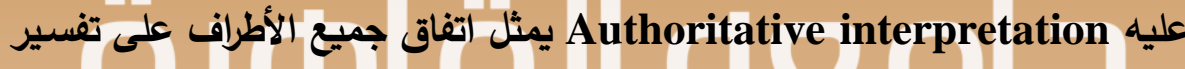

(1) Loc. Cit.

(2) Richard Gardiner, Treaty interpretation, op. cit., p. 86-88.

(3) G.C. Fitzmaurice, Reservations to multilateral conventions, op. cit., p. 223.

(4) Frank Horn, Reservations and interpretative declarations to multilateral treaties, op. cit., p. 246. 
معين للإتفاقية وبالتالى يكون التفسير ملزماً ورسمياً. غير أن التقدم بسؤال عن

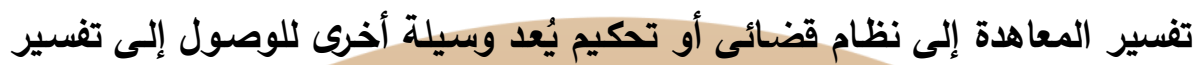

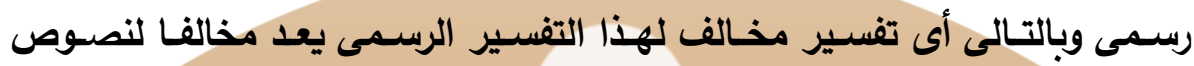

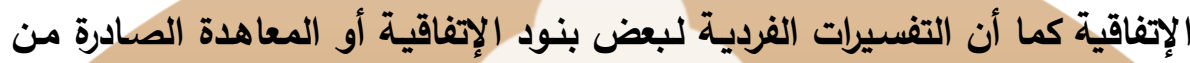

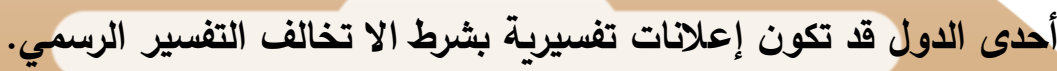

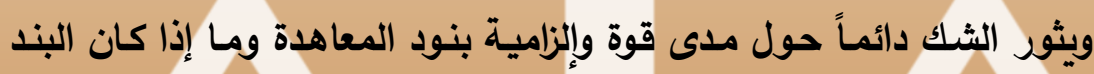

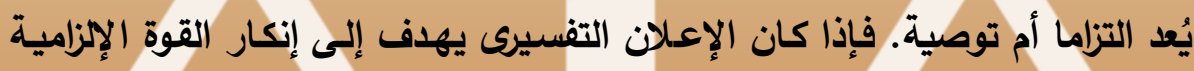

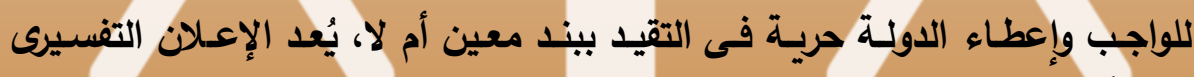

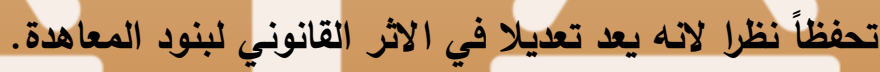

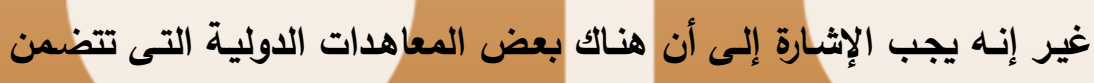

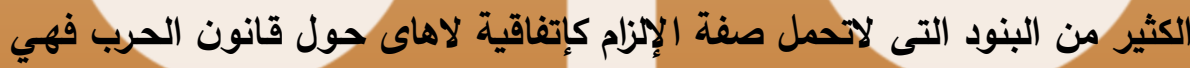

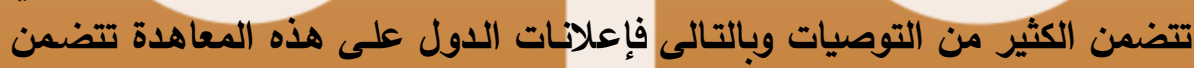

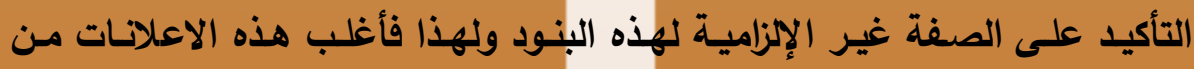

طبيعة تفسيرية.

ولعل من المنطقى أن نفرق بين المفهوم نفسكه والوصف الذى تسبغه الدول

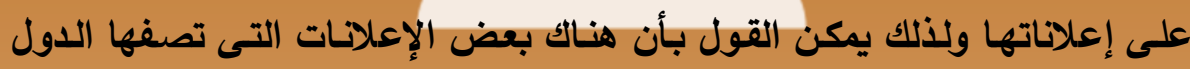

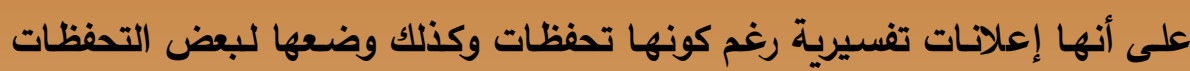
التي في حقيقتها ما هي الا إعلانات تفسيرية.

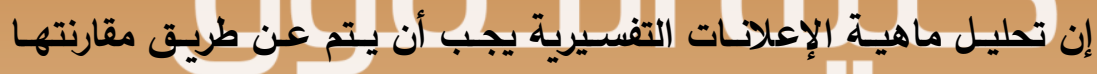

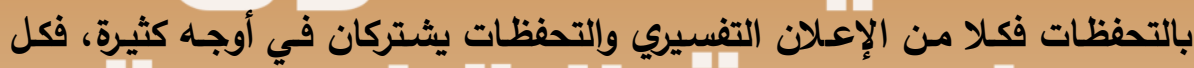

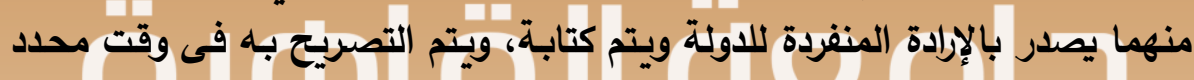

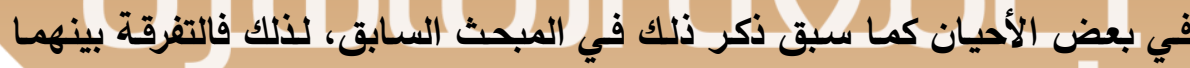
تقوم على الاعتماد علي مضمون كل منهماً.

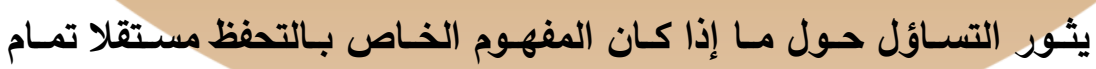

(1)Final Agreement was signed on October 18, 1907, and entered into force on January 26, 1910 
الإستقلال عن المفهوم الخاص بالإعلان التفسيرى أم أن المفهومين يتثابهان فى إنى

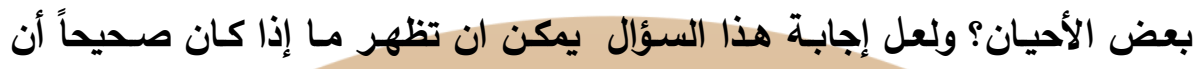

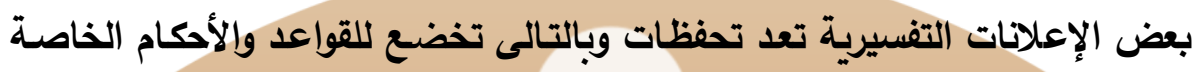

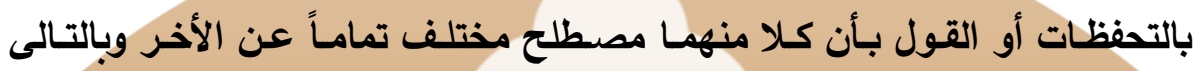

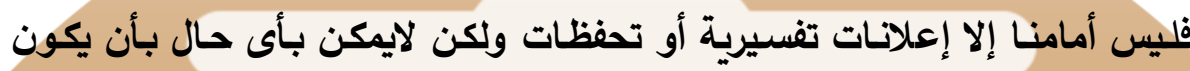

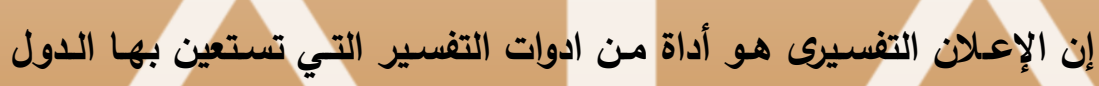

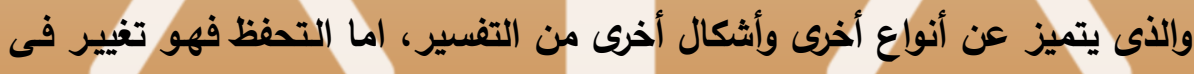

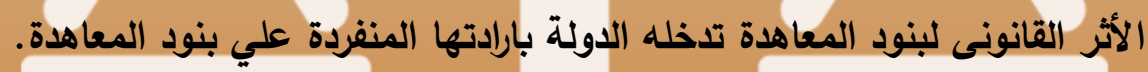

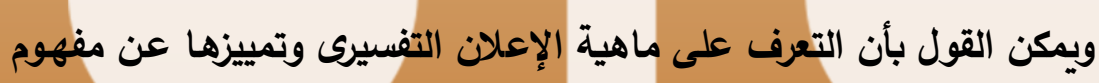

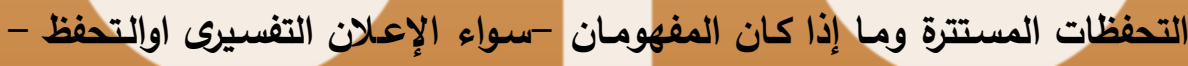

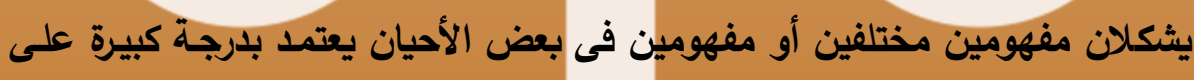

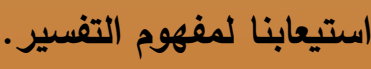

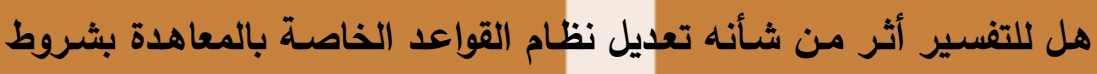

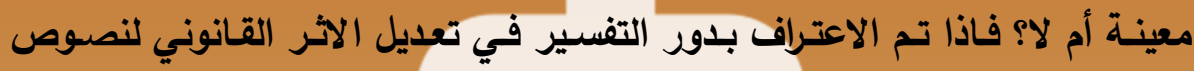

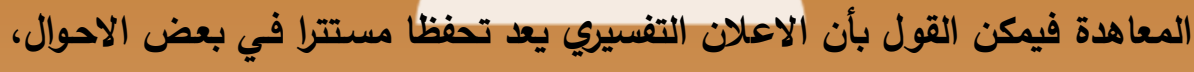

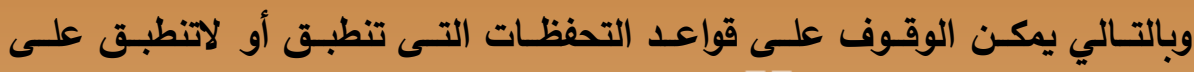

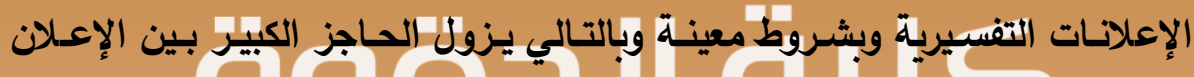

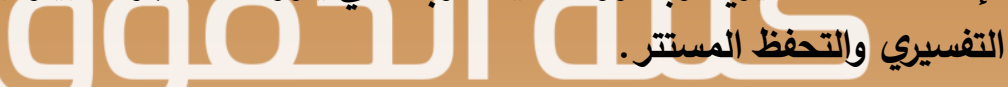

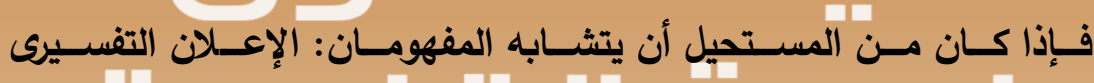

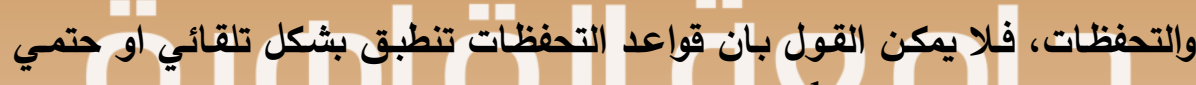
على الإعلانات التفسيرية.

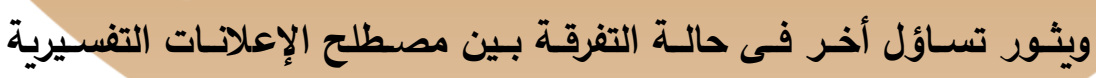

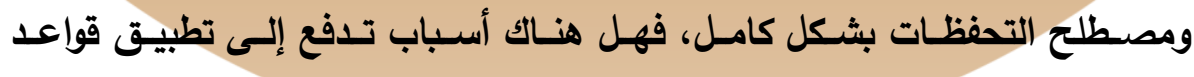

(1) G.C. Fitzmaurice, Reservations to multilateral conventions, op. cit., p. 12. 


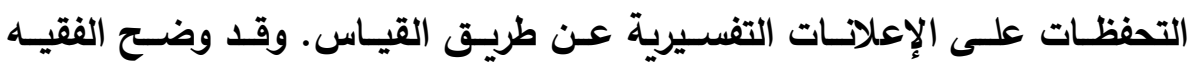

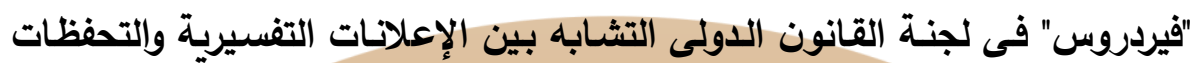

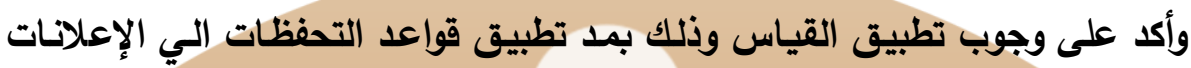
التفسيرية.

و لعله من المفيد التعرض بداية لمسألتين مهمتين في معرض بحث إشكالية التفرقة بين الإعلانات التفسيرية والتحفظات المستترة: (1) المسألة الأولى: وهى السؤال الخاص بـ " الأثر الإستبعادى "بلإعلاتحات التفسيرية

وقد قال بهذه النظرية "فيردروس" وبعده توسكان وكلاهما ينـى نظريتيه على

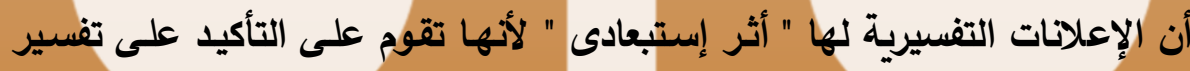

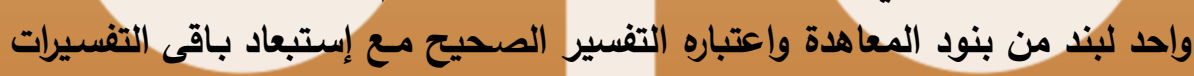

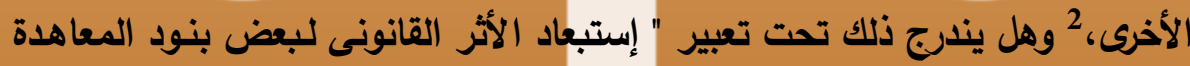

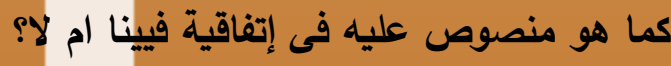

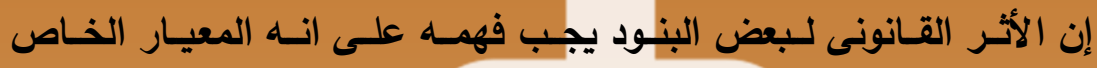

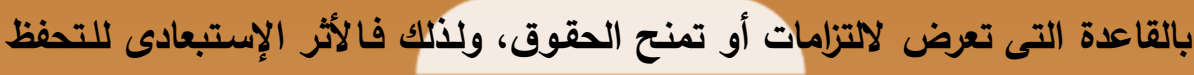

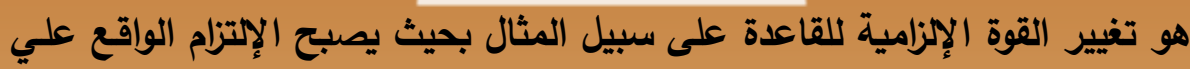

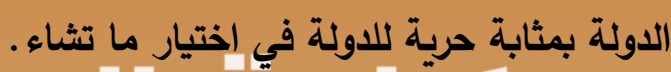

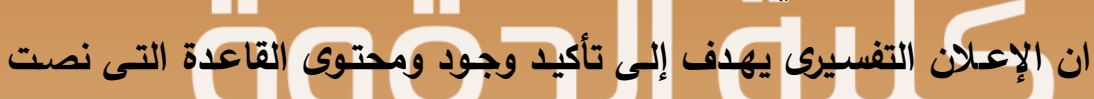

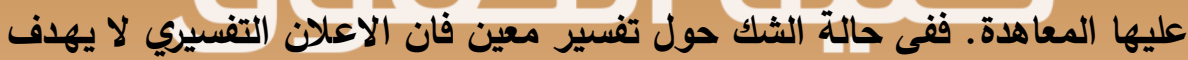

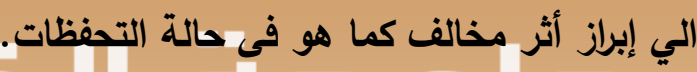
فإذا كان التحفظ المستترة يمس القاعدة نفسها فإن الإعلان التفسيرى يدور

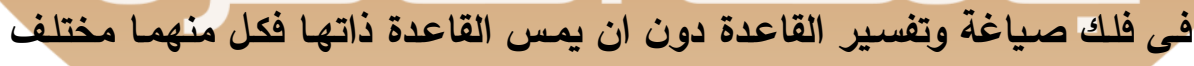

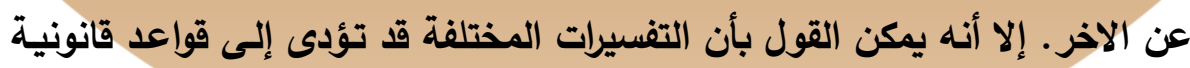

(1) Frank Horn, Reservations and interpretative declarations to multilateral treaties, op. cit., p. 235.

(2) Loc. cit. 
مختلفة ولذلك فالإعلان التفسيرى قد يمس الأثر القانونى لبعض البنود بثكل غير

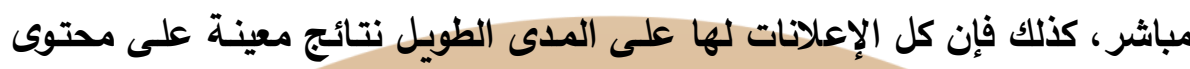

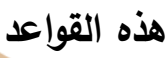

إن الاعتراف بالاثر الاستبعادي للإعلان التفسيري يعقد من إثكالية التفرقة

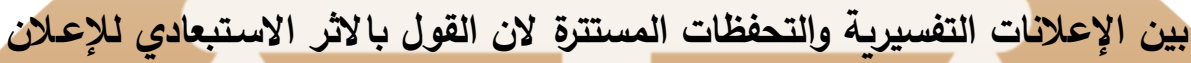

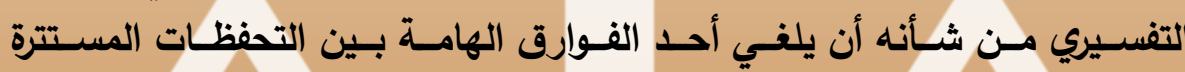
والإعلانات التفسيرية. (2) المسألة الثانية: فتتعلق بالإعلانات التفسيرية المشروطة: يقسم الفقيه هورن الإعلان التفسيري إلى نوعين:

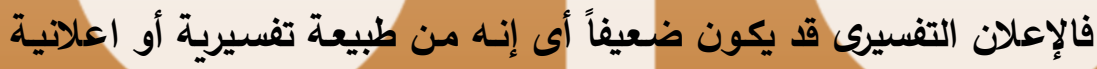

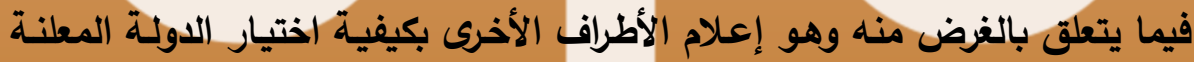
لتفبير معين لبعض البنود وكيفية تطبيقها.

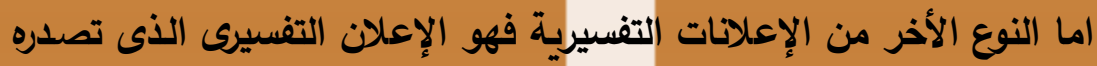

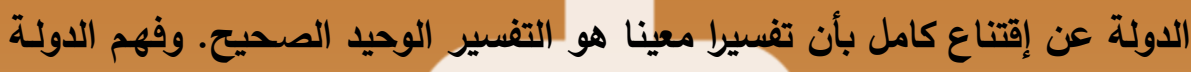
لهذا البند هو شرط مطلق للمشاركة في المعاهدة. 2

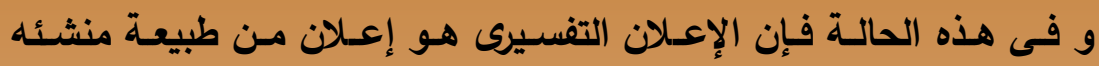

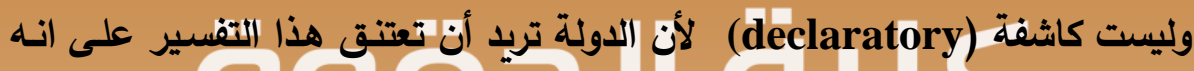

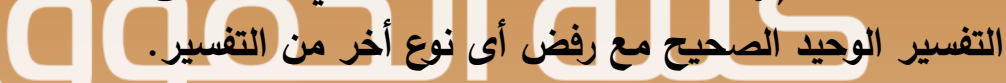

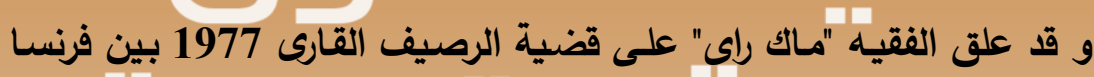

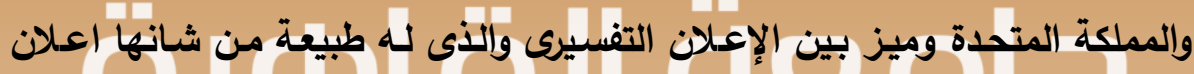

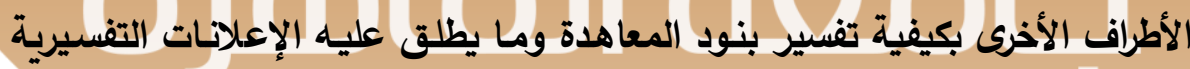

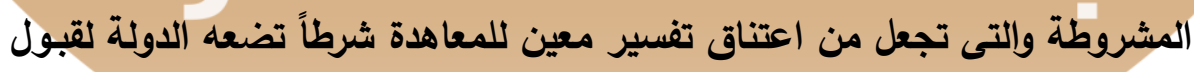

(1) Loc. cit.

(2) Loc. Cit. 


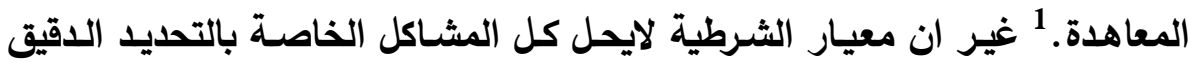

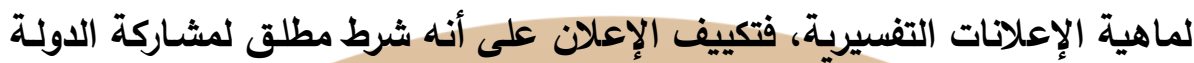

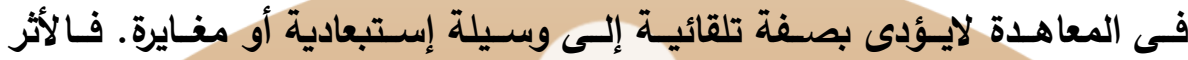

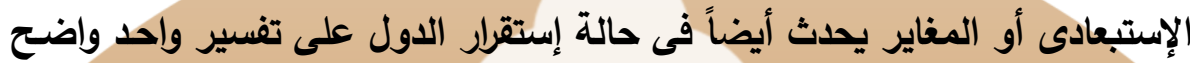

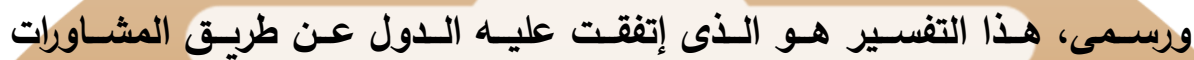

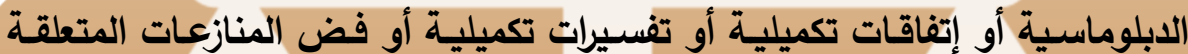

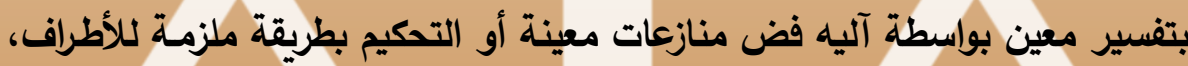
لذلك فالثرطية ليست هي الوسيلة الوحيدة لاستبعاد تفسير وتطبيق تفسير آخر. 2 ومع ذلك فإذا تم تكييف بعض التفسيرات على أنها تفسيرات صحيحة وكانت

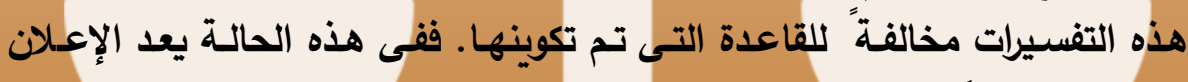
التفسيرى تحفظاً مستترا وبالتالي تنطبق قواعد التحفظات علي هذه التهاء الاعلانات. وعلي ذلك فإن رأي تومسكان بثأن معيار الشرطية على أنه المعيار الصالح

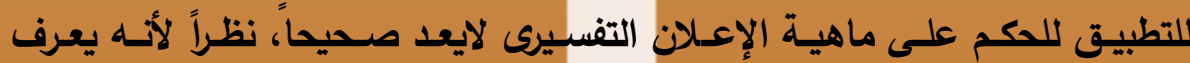

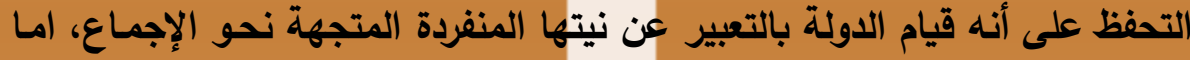

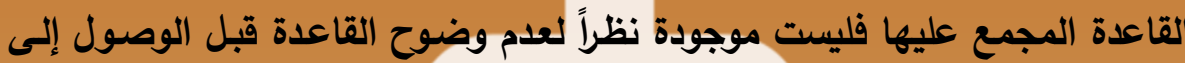
التفسير الرسمى.

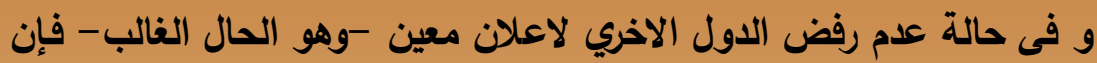

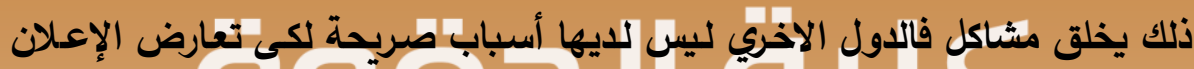

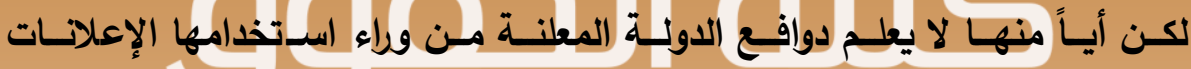
التفسيرية. فإذإ كـان نظـام التحفظـات سـيطبق على الإعلانـات التفسيرية فيإن قاعدة القبول الضمنى ستنطبق أيضاً. 4

(1) McRae, The legal effect of interpretative declarations, op. Cit., p. 29.

(2) Ibid., p. 28.

(3) Frank Horn, Reservations and interpretative declarations to multilateral treaties, op. cit., p. 235.

(4) Loc. Cit. 
أما إذا كان الإعلان التفسيري قد تم التوصل اليه عن طريق قرار قضائى

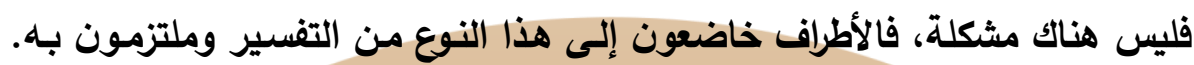

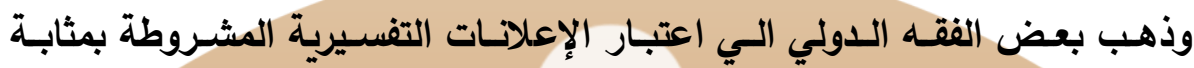

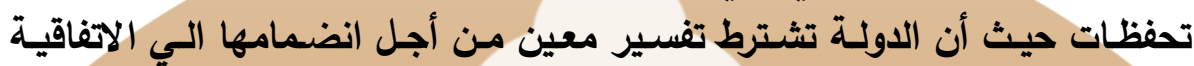
وبالتالي فان الأثر القانوني لهذا البند سيتغير تبعا لذلك.

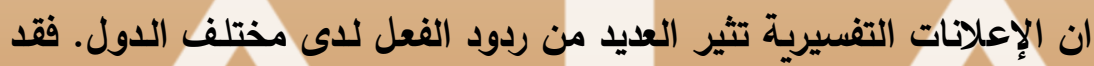

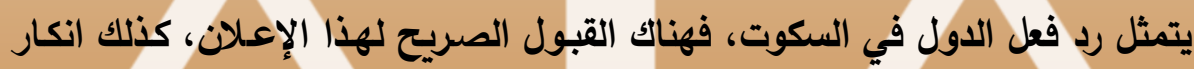

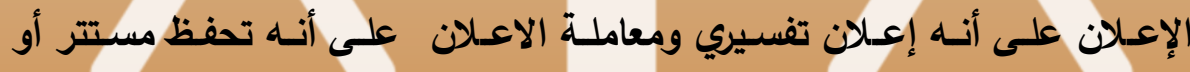

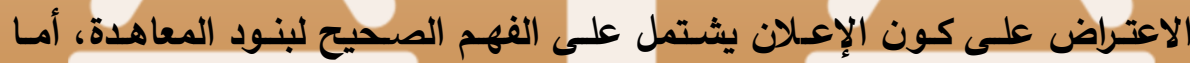

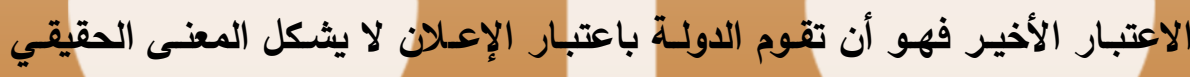

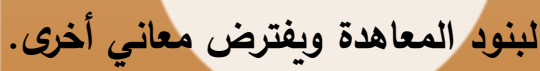

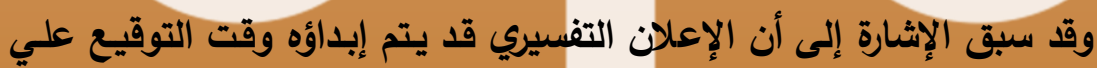

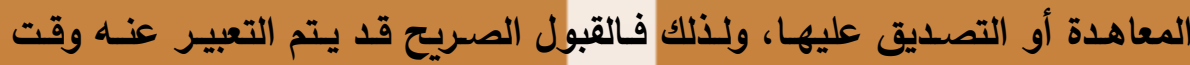

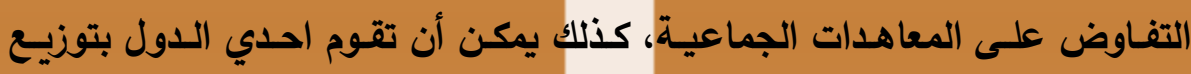

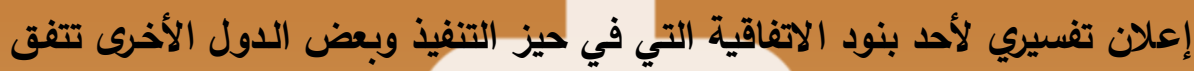

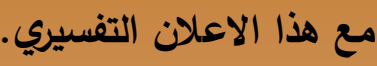

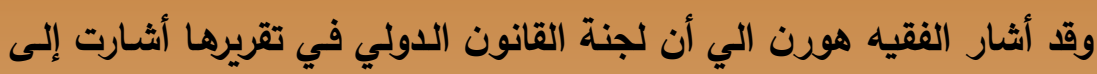

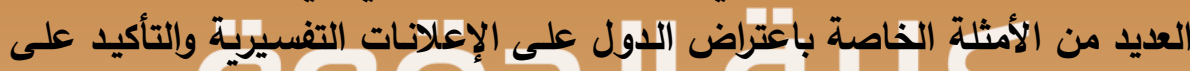

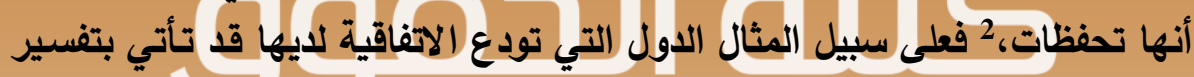

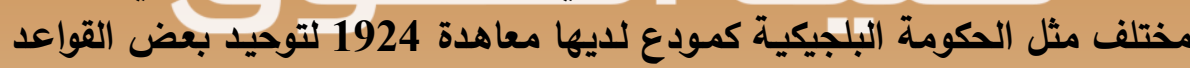

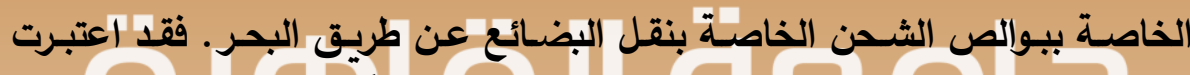

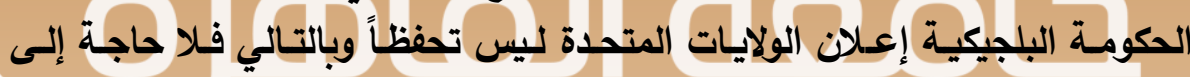

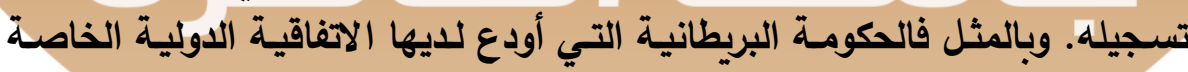

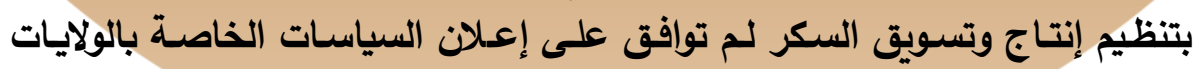

(1) Henry J. Bourguignon, The Belilos case: new light on reservations to multilateral treaties, 29 Va. J. Int'l L. 355 (1988-89

(2) Loc. Cit. 


\section{المتحدة طالما لم توافق عليه الدول الموقعة.1$$
\text { (ب) أنواع الإعلانات التفسيريـة: }
$$

جرى الفقـه الدولي علي إجراء تقسيم كلاسيكي للإعلانـات التفسيرية بين

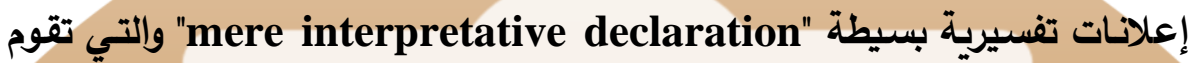
الدولة المعلنة بإصدار الاعلان معلنة عن فهمها لبنود معينة علي نحو معين والتي

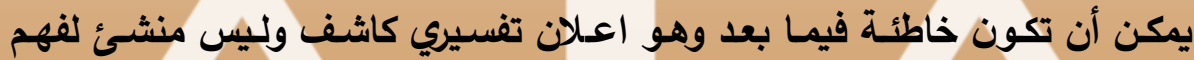

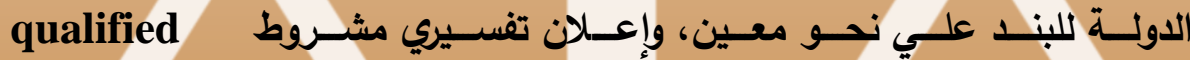
تفئري

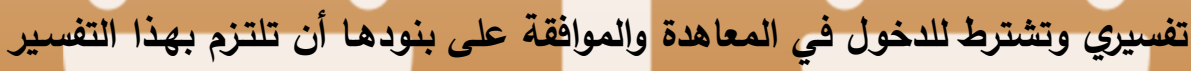

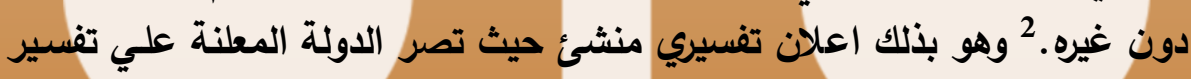

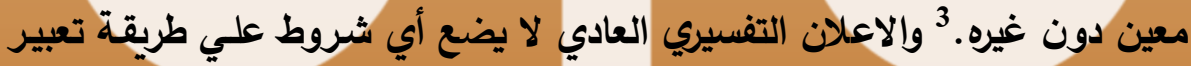

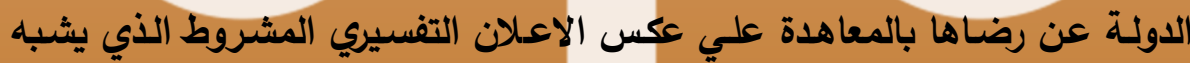

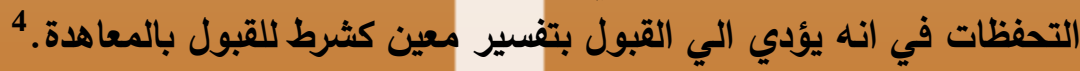

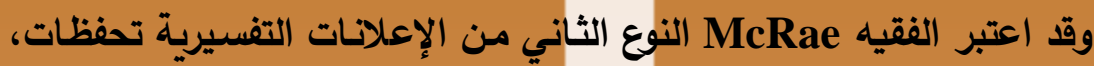

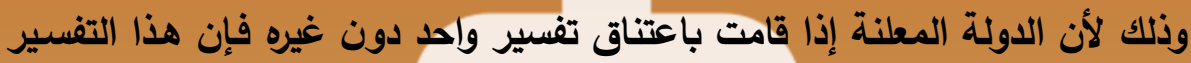

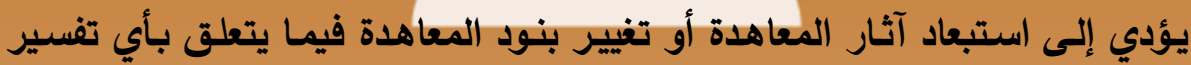

(1) Loc. Cit.

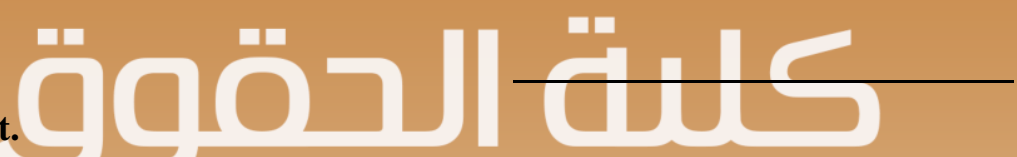

(2) P. Nelson, Declarations, statements and disguised reservations with respect to the convention on the law of the sea, International law and Comparative law Quarterly, vol. 50. no. 4 (oct. 2001), p. 767, See also Malcolm Shaw, International law, op. cit., p. 822-23 (simple \& conditional interpretative declarations-mere \& qualified interpretative declarations); See also Ian Sinclaire, The Vienna Convention on the law of treaties, op. Cit., at 52.

(3) Frank Horn, Reservations and interpretative declarations to multilateral treaties, op. cit.; p. 235

(4) International law commission report, 1999 v. II pt. 2 U.N.Y.B. Int'l L. Commn 105 (1999) para. 10. 


\section{اخر وبالتالي يقع ذلك تحت تعريف التحفظات. 1}

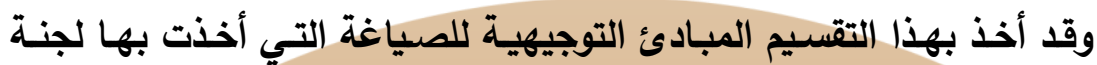

القانون الدولي حيث أكلت على ان " الإعلان التفسيري المشروط هو ذلك الإعلان

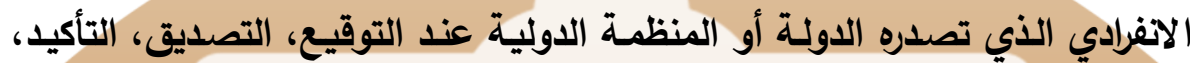

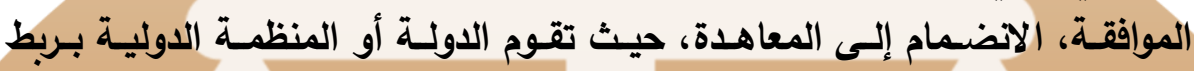

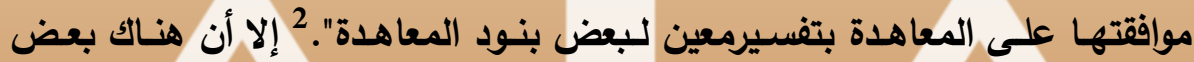

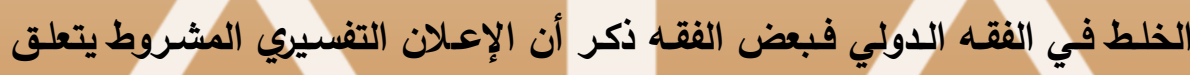

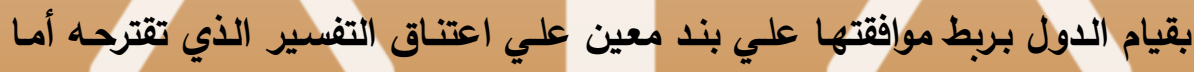

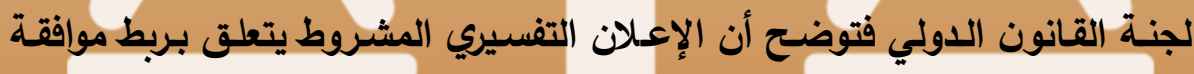

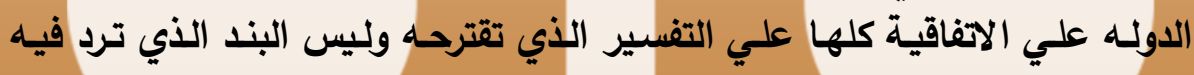
اعلان تفسيري.

و يبـدو أن اللجنـة ليس مـن لأيها اعتبـار الإعلانـات التفسيريـة المشـروطة

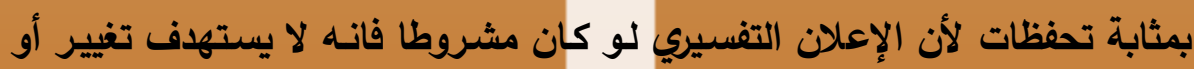

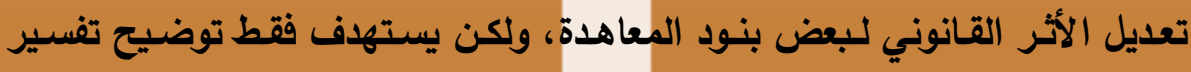

(1) McRae, The legal effect of interpretative declarations, op. cit., p. 24 (1979).

(2) "A unilateral statement formulated by a state or an international organization when signing, ratifying, formally confirming, accepting, approving, or acceding to a treaty, or by a state when making notification of succession to a treaty, whereby the state or international organization subjects its consent to be bound by the treaty to a specific interpretation of the treaty or of certain provisions thereof, shall constitute a conditional interpretative declaration" International law commission, 1999 v.II pt.2 U.N.Y.B. Int'l L. Comm'n 1031999 at paragraph 1-1.2.1".

(3) L.D.M. Nelson, Declartions, Statements and Disguised Reservations with respect to the Convention on the Law of the Sea, International and Comparative Law Quarterly, Vol. 50 p. 777. 


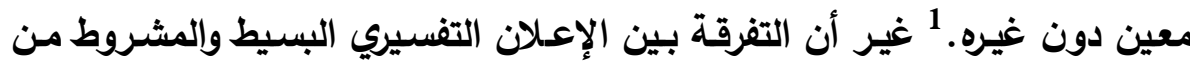

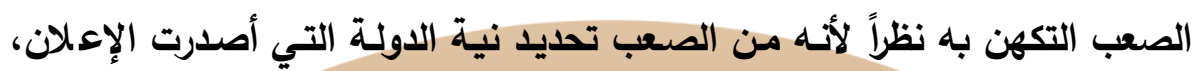

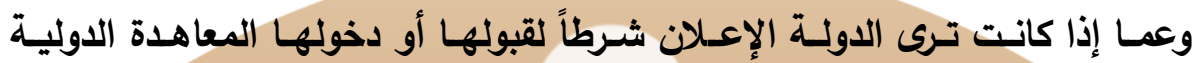

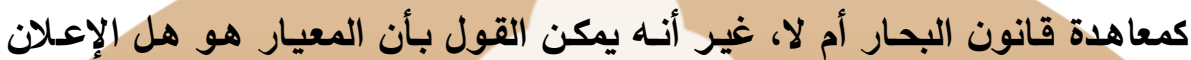

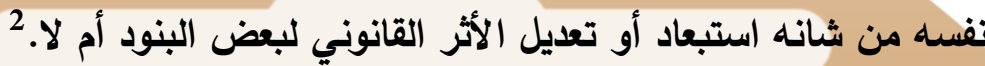

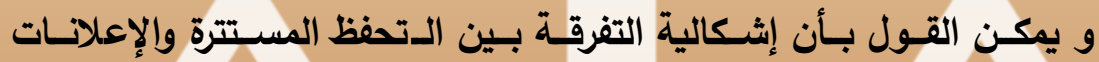

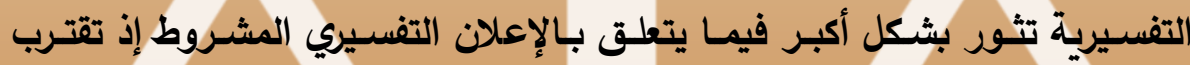
خصائص الإعلانات التفسيرية من خصائص التحفظات المسترة بثكل كبير.

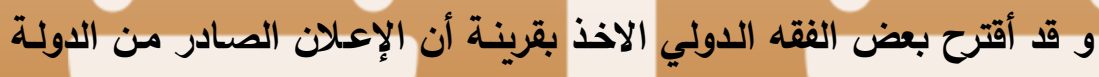

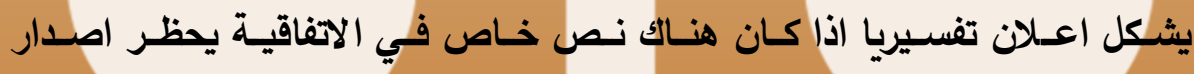

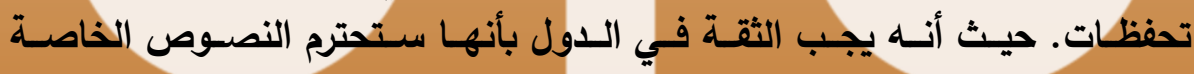
بالتحفظات.

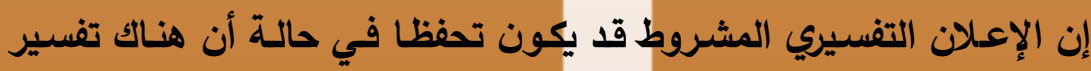

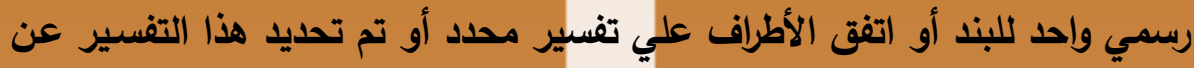

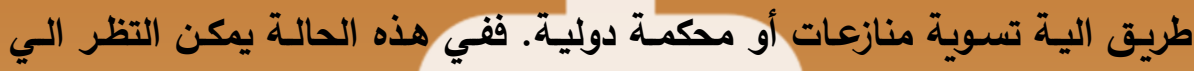

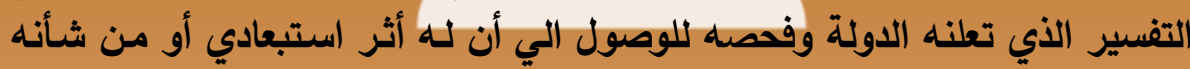

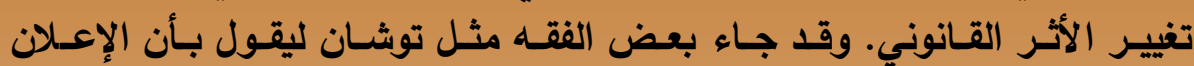

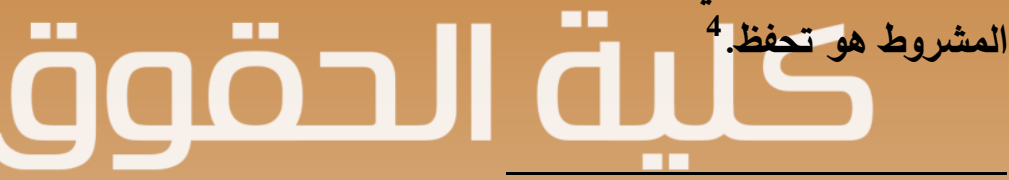

(1) P. Nelson, Declarations, statements and disguised reservations with respect to the convention on the law of the sea, op. cit., p. 767 .

(2) Malcolm Shaw, International law, op. cit., p. 823; See also International law commission, 1999 v.II pt.2 U.N.Y.B. Int'l L. Comm'n 1081999 at paragraph 3 at 108.

(3) L.D.M. Nelson, Declartions, Statements and Disguised Reservations with respect to the Convention on the Law of the Sea, International and Comparative Law Quarterly, Vol. 50 p. 778.

(4) Frank Horn, Reservations and interpretative declarations to multilateral treaties, op. cit.; p. 239 


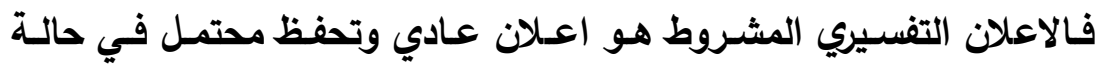

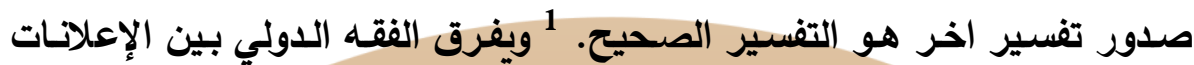

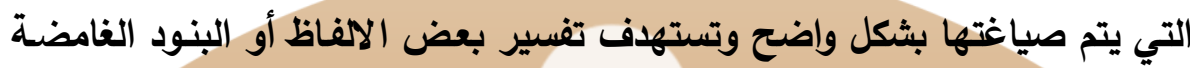
وإعلانات تغير من القاعدة القانونية وبالتالي تعد تحفظا.

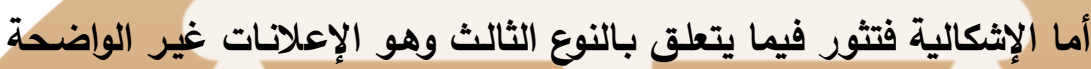

والتي يصب تكييف ما اذا كانت اعلان تفسيري أو تحفظ. 2

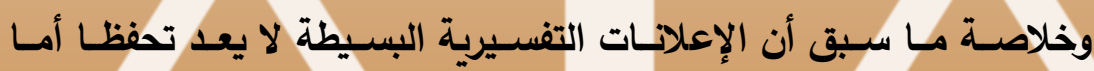

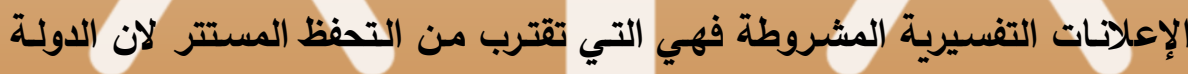

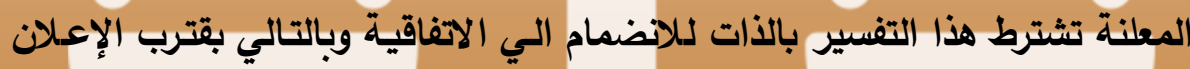
التفسيري المشروط من التحفظ المستتر .

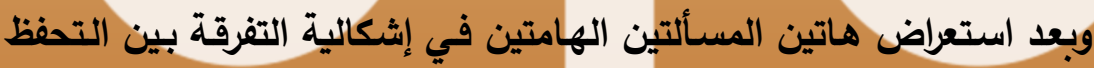

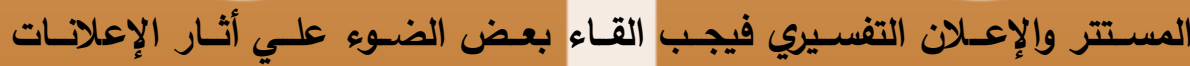

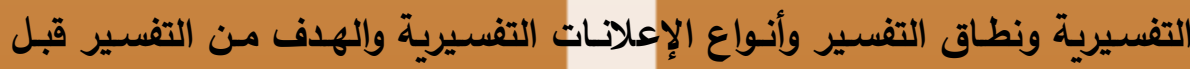

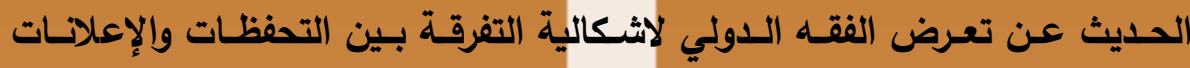
التفسيرية ثم نغتم بالتفرقة بين التحفظ المستتر وغيره من الإعلانات الأخرى.

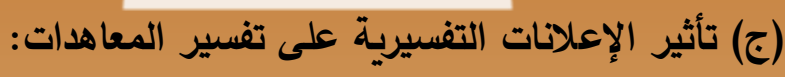

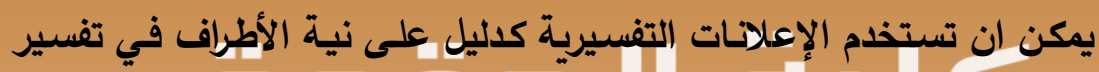

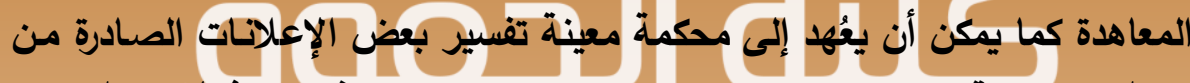

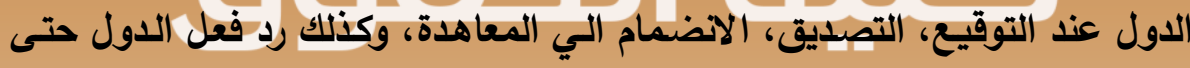

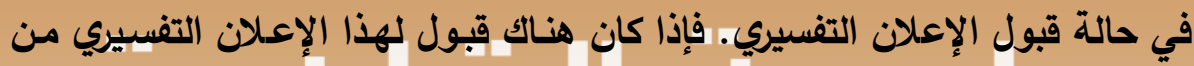

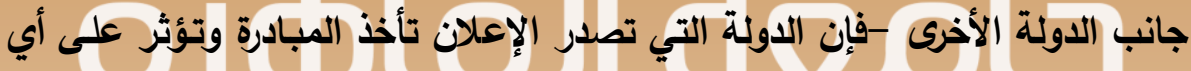
تفسير لاحق للمعاهدة. 3

(1) Id. at p. 242

(2) Id. at p. 245

(3) George K. Walker, Professional's definitions and state's interpretative declarations (understandings, statements, or declarations) for the 1982 law of the Sea convention, op. cit., p. 518-524. 
وقد تعرضت محكمـة العدل الدولية في رأيها الاستثـاري لاهمية الاعلانـات

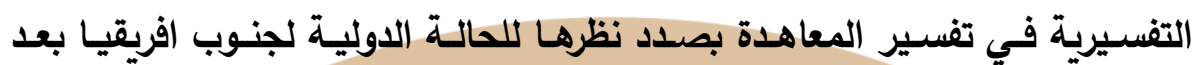

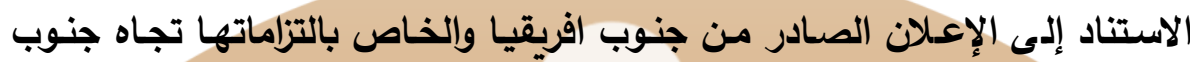

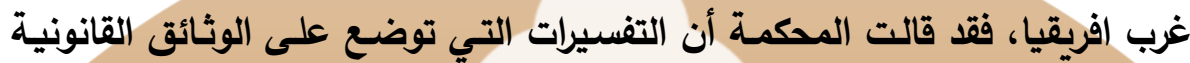

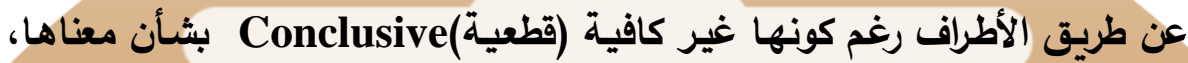

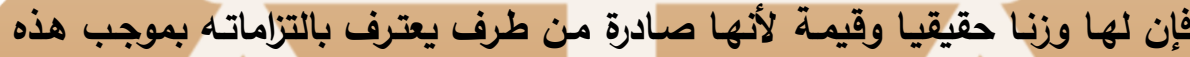

الوثيقة.

ويجدر الاشـارة الي ان التفسير لـه دور كبير عند تكييف اي اعلان صـادر

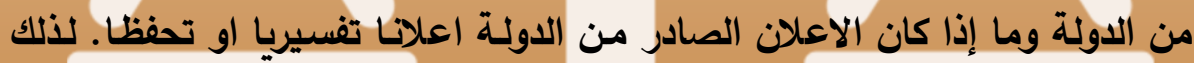

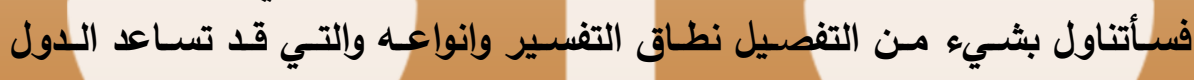
المختلفة في الوصول الي تكييف دقيق للاعلانات التفسيرية. : (د) نطاق التفسير (د)

قسـم بعض الفقهاء التفسير إلى عدة أنـواع، فهنـاك تفرقة بين "التفسير

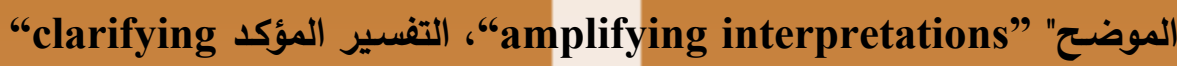

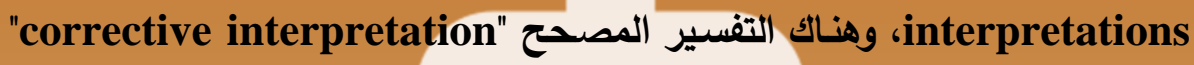

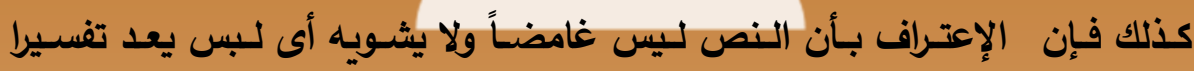

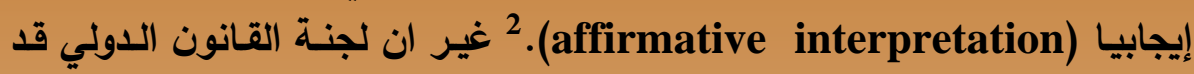

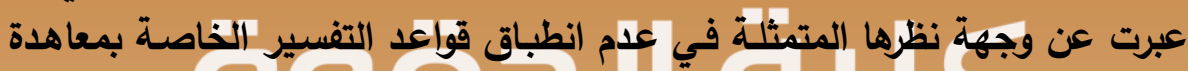
فيينا علي الاعلانات التفسيرية نظرا لاتها اعلانات فئات انفرادية. 3 affirmative interpretation : التفسير الإيجابيى الاعيرياته (1) قد تؤكد دولة -على سبيل المثال- علي وضوح بنود المعاهدة بإستخدام ألفاظ مرادفة للألفاظ المستخدمة فى بنود المعاهدة، ويعد الإعلان إيجابيا اذا كان لانيل

(1) ICJ Reports, 1950, p. 121.

(2) Frank Horn, Reservations and interpretative declarations to multilateral treaties, op. cit., p. 246.

(3) International law commission report, 1999 v. II pt. 2 U.N.Y.B. Int'l L. Commn 108 (1999) para. 5. 
يوجد خلاف بين الأطراف الأخرى للمعاهدة وكذلك يعد التفسير أو الإعلان صحيحا

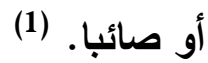

ومثال للتفسير الإيجابى قيام دولة الأرجنتين بإصدار إعلان تفسيرى للمادة

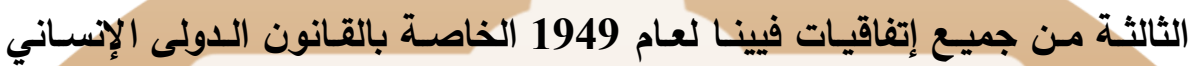

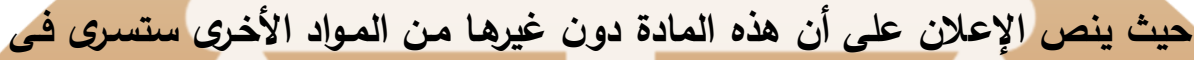

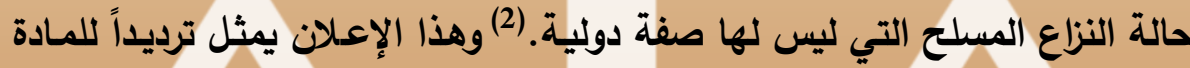

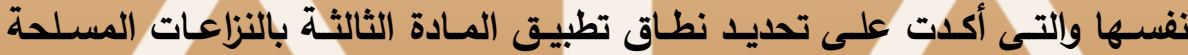

وليس لها صفة دولية.

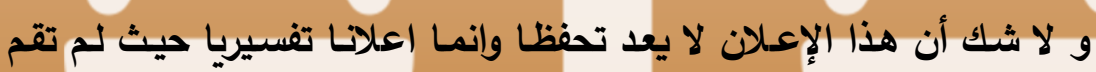

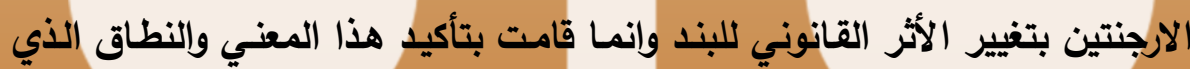

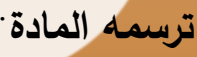

clarifying interpretation. : التفسير الموضح

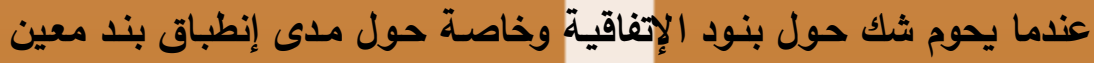

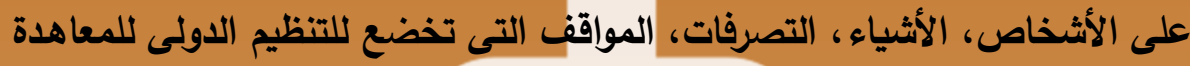

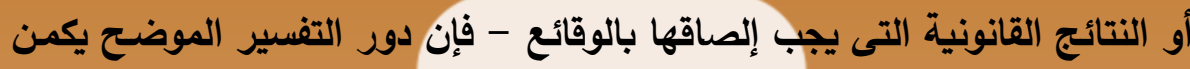

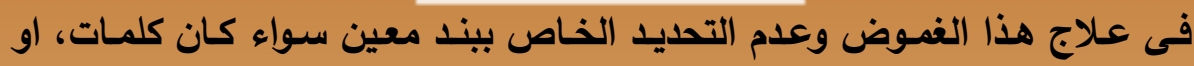

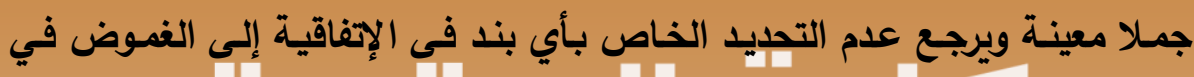
بعض الحالات. و فى حالات اخري تستخدم بعض الكلمات والتعبيرات التى تحتمل أكثر من

(1) Frank Horn, Reservations and interpretative declarations to multilateral treaties, op. cit., p. 246.

(2)" Article 3....shall be the only Article to the exclusion of all others, which shall he applicable in the case of armed conflicts not of an international character."

(3)A state party is only bound by the following obligations: "In the case of an armed conflict not of an international character occurring in the territory of one of the high contracting parties." 
معنى نظراً لإستخدامها بطريقة مختلفة من دولة لأخرى: فهناك كلمـات اتفق على

$$
\text { إستخدامها بطربقة معينة. }
$$

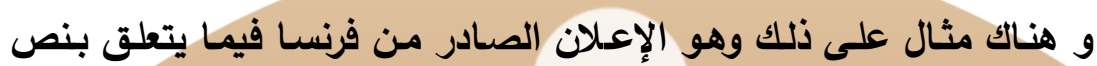

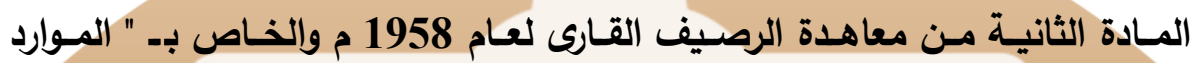

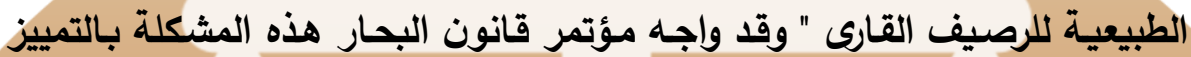

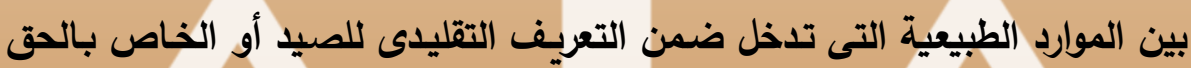

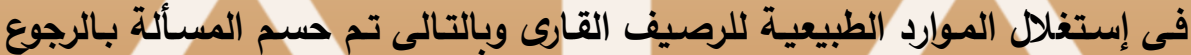

إلى المعيار المميز وهو قاع البحر . 3) التفسير المضيف:

يهرف هذا التفسير الي النص علي أمور كانت منسية في الاتفاقية الدولية

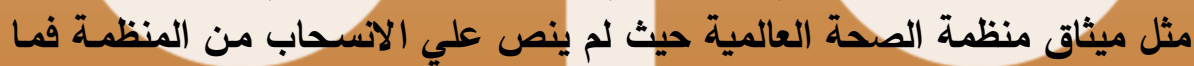

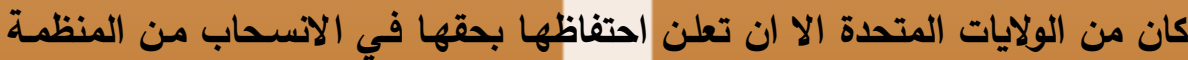
في أي وقت بشرط اخطار المنظمة باخطار مسبق مدته الان عام. 3 (ه) التهدف من التفسير : (ه)

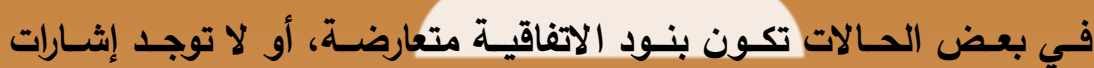

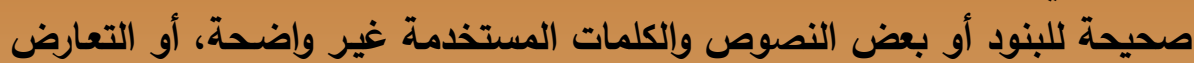

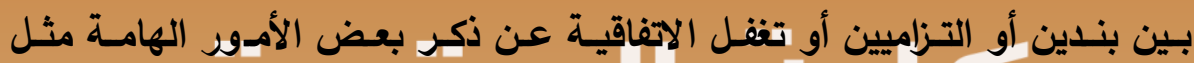

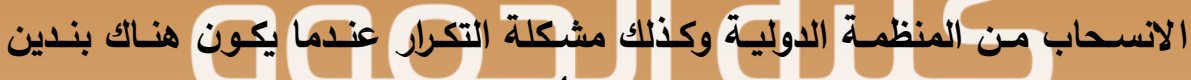

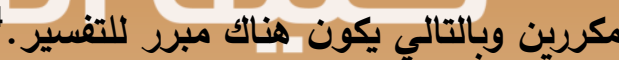
إن التفسير الرسمي للاتفاقية يتم الوصول اليه عن طريقين: إمـا عن طريق

(1) اتفاقيات فيينا لعام 1949. د. أحمد أبو الوفا الوسيط القانون الدولى العام ص 124-136
(2)United
Nations
Treaty
Collection,

http://treaties.un.org/Pages/ViewDetails.aspx?src=TREATY\&mtdsg_no =XXI-4\&chapter $=21$ \&lang $=$ en

(3) Frank Horn, Reservations and interpretative declarations to multilateral treaties, op. cit.; p. 255

(4) Id. at p. 259 
اتفاق أطراف الاتفاقية أو باللجوء الي وسيلة قضائية أو فض المنازعات للوصول

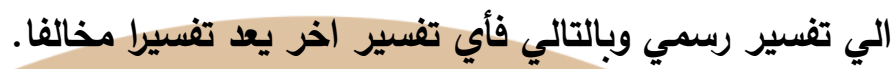

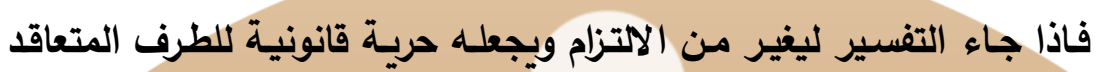

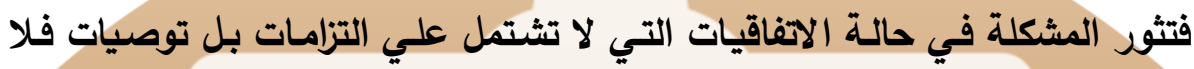
شك أن الإعلانات المتعلقة بها تعد إعلانات تفسرية من شأنها أن تؤكلد أوتفسر

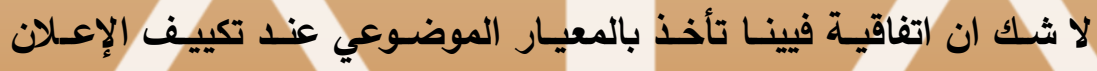

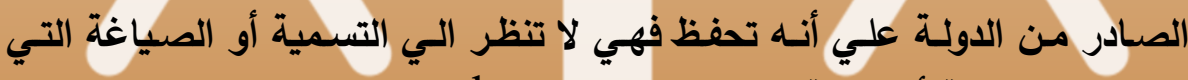

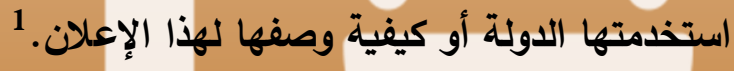

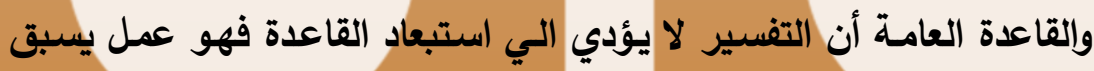

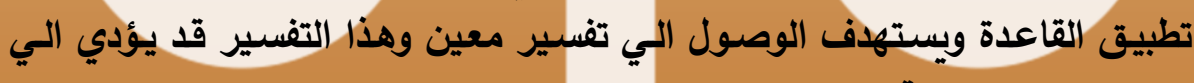
تطبيق قواعد مختلفة لكنه لا يستبعد القاعدة تماما.

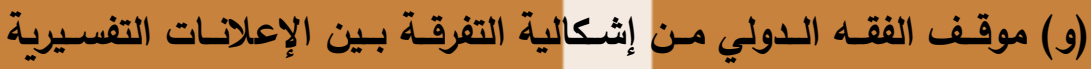
والتحفظات:

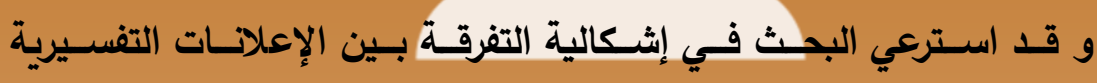

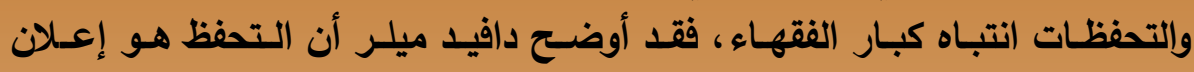

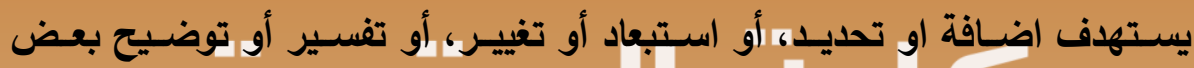

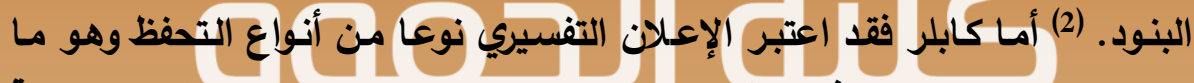

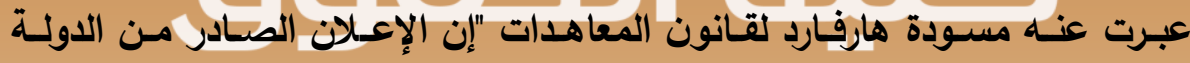

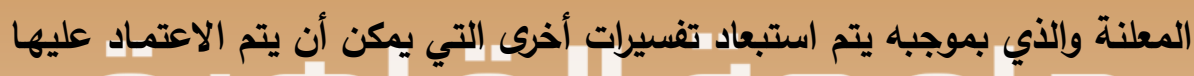

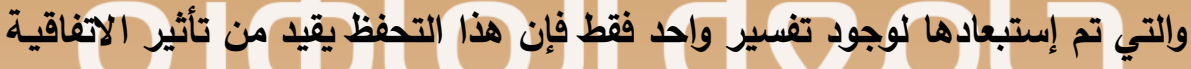

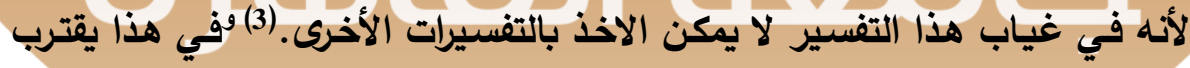

(1) Frank Horn, Reservations and interpretative declarations to multilateral treaties, op. cit.; p. 236

(2) Id. at p. 76 (citing David Hunter Miller, Reservations to treaties (1919).

(3) Loc. Cit. 
الإعلان التفسيري من التحفظ.

وقد ادخل الفقيه كيرلوف الإعـلان التفسيري ضمن التحفظات أمـا الفقهاء

الآخرون ككردسو فقد اعتبر الإعلان التفسيري مفهوما مستقلا عن التحفظات. والتفرقة بين الإعلانات التفسيرية والتحفظ لها أهمية كبيرة تستدعي النظر

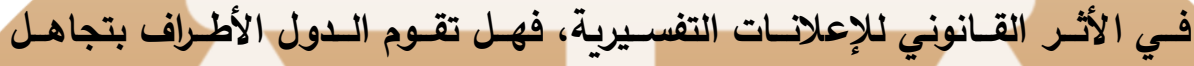
الإعلانات التفسيرية، او الموافقة عليها أو رفضها؟ الوعات

ويختف الفقه الدولي حول هذه الجزئية ويرجيع ذلك الي أن بعضا من الفقه التها

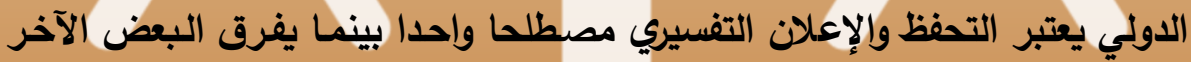

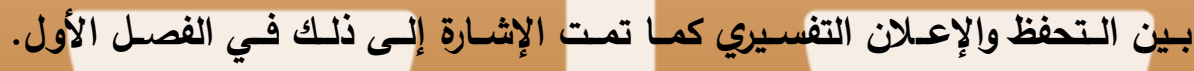

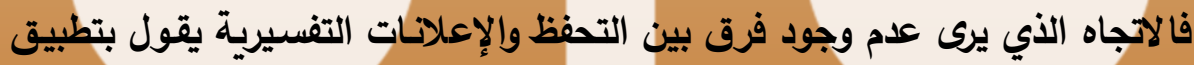

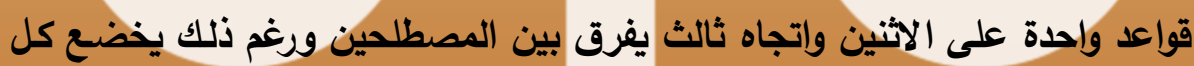

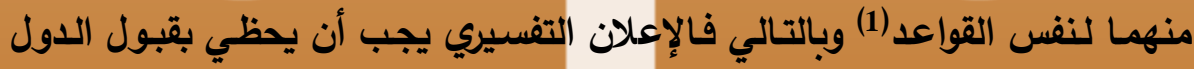

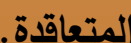

أما الاتجاه الذي يرى التفرقة بين التحفظ والإعلان التفسيري فيرى أن الأثر

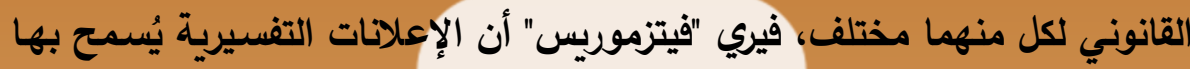

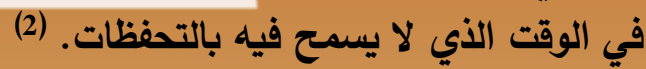

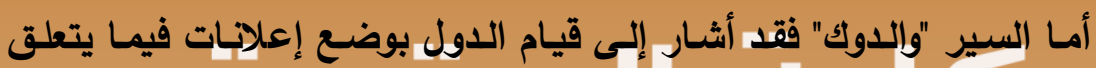

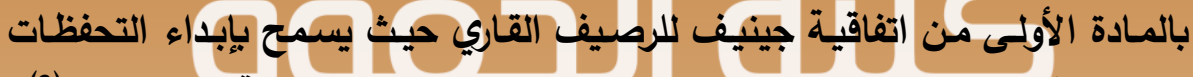

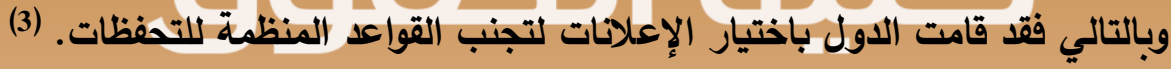
و بضيف الفقيه والدوك أن التحفظات لا تتضمن إعلانات تهدف الي تفسير وتنفيذ الاتفاقية مـا لـم يتضمن هذا الإعلان تغييـر للبنود الموضـوعية أو الاخدار

(1) George K. Walker, Professional's definitions and state's interpretative declarations (understandings, statements, or declarations) for the 1982 law of the Sea convention, op. cit., p. 518-524.

(2) McRae, The legal effect of interpretative declarations, op. cit., p. 158 59.

(3) Ibid. at p. 159. 


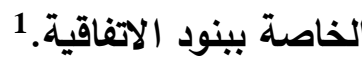

و بالنسبة لممارستات اللدول فهي تختلف بالنسبة للإعلانـات التفسيرية:

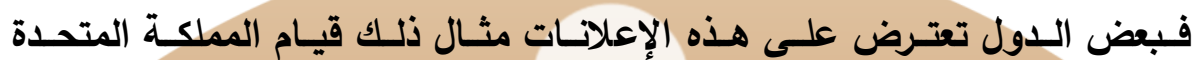

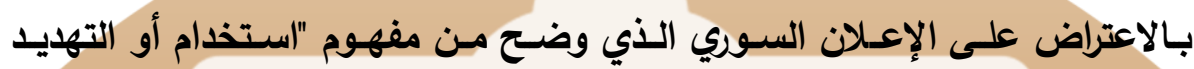

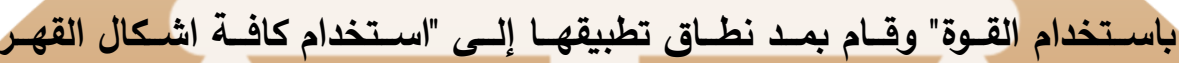
الاقتصادي، السياسي، العسكري وإلنفي".

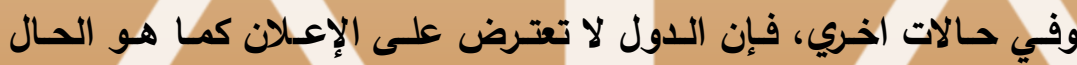

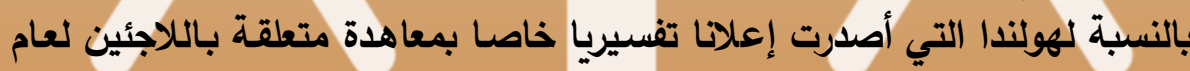

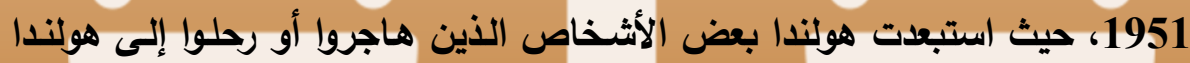

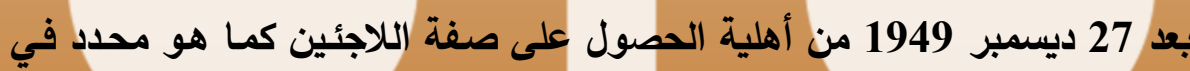
المادة الاولي من الاتفاقية.

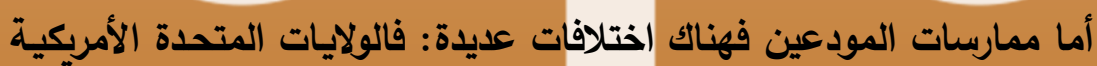

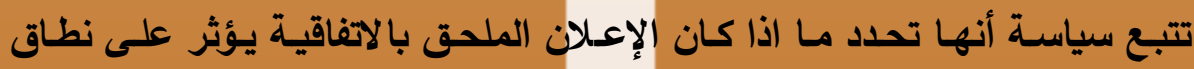

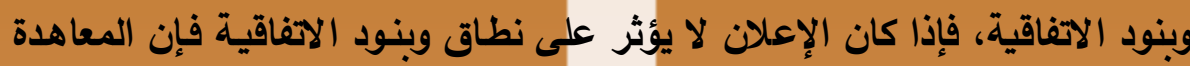

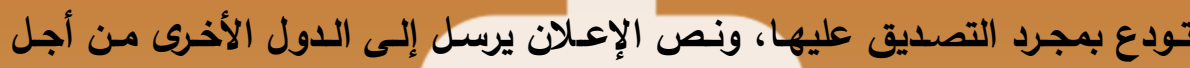

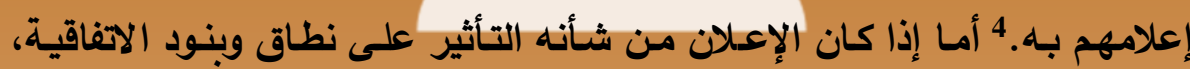
فإن إيداع التصديق يتم ايقافه لحين استعراض الآراء الداء المختلفة للدول الأخرى.

(1) L.D.M. Nelson, Declartions, Statements and Disguised Reservations with respect to the Convention on the Law of the Sea, International and Comparative Law Quarterly, Vol. 50 p. 770.

(2)

$$
\text { United Nations Treaty }
$$

Collection.

http://treaties.un.org/Pages/ViewDetailsII.aspx?\&src=TREATY\&mtdsg no $=\mathrm{V} \sim 2$ \&chapter $=5$ \& Temp $=$ mtdsg 2\&lang $=$ en

(3)

$$
\text { United Nations Treaty Collection, }
$$

http://treaties.un.org/Pages/ViewDetailsII.aspx?\&src=TREATY\&mtdsg no $=V \sim 2$ \&chapter $=5 \&$ Temp=mtdsg2\&lang=en

(4) Frank Horn, Reservations and interpretative declarations to multilateral treaties, op. cit., p. 76 (citing David Hunter Miller, Reservations to treaties (1919). 
أما السكرتير العام للأمم المتحدة فلا يقوم بدراسـة الإعلانـات طالمـا أنـه ليس

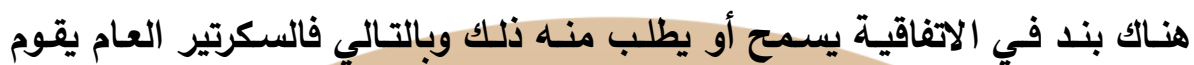

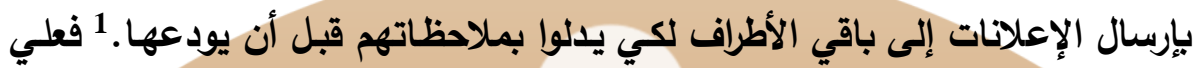

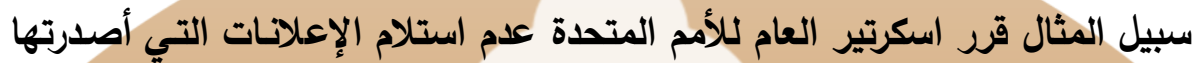

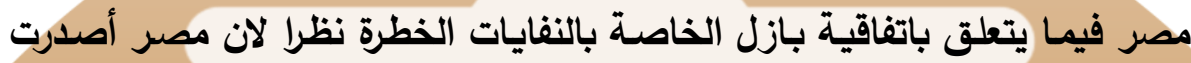

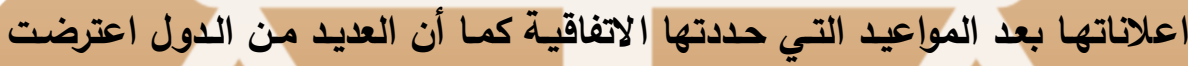
علي هذه الإعلانات. أما هولندا على سبيل المثال فـلا تقوم بنفس الاجراء الذي تقوم بـه الولايات المتحدة وبالتالي فهي تقبل الوصف الذي الحقته الدولة المعلنة علي الإعلان. فترى سويسـرا في قضية Belilos أنـه طالمـا وافقت الدول على الإعلان

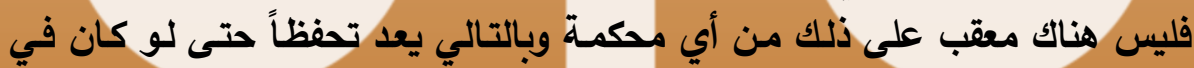

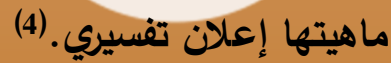
ويجد ذلك الرأي صدى عند الفقيه Imbert والذي يأخذ بمعيار موضوعي

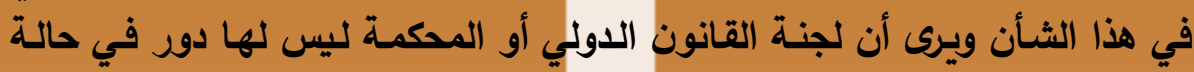

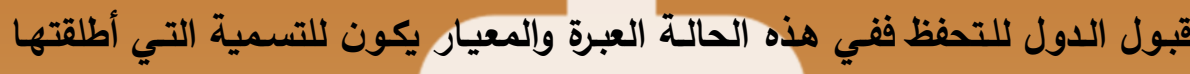

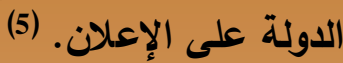

(ي) التمييز بين التحفظات المستترة والإعلانات الأخرى التي قد تختلط به: و يري الفقـه الدولي أنه يجب التمييز بين التحفظات المستترة والإعلانـات الأخرى التي قد تختلط بها أو تتشابه معها وذلك علي النحو التالي:

(1) Loc. Cit.

(2) دـ عبد الله المسدي، النظام القانوني للاعلانات التفسيرية الصادرة عن الدول بخصوص المعاهدات الدولية، ص الد 84 (2004) (20)

(3) Ibid., p. 120.

(4) Ibid., at p. 120-22 (citing Belilos case, 132 Eur. Ct. H.R. at 28, reprinted in 10 Eur. Hum. Rts. Rep. at 487).

(5) Pierre-Henri Imbert, Reservations to the European Convention on human rights before the Strasbourg commission: the Temeltasch case, 33 Int'l \& Comp. L.Q. 593-95 (1984). 
1) الإعلانـات المتعلقـة بوقت سـريان الاتفاقيـة: وتنقسـم هذه الإعلانـات الـي

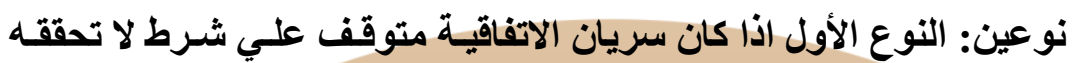

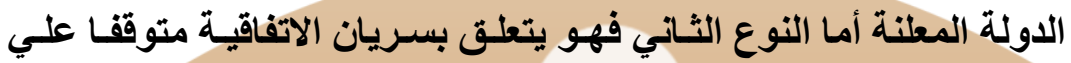

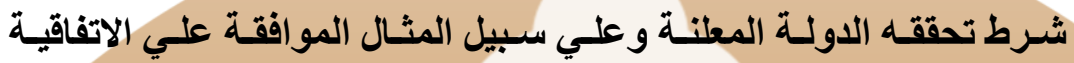
بشرط التصديق.1

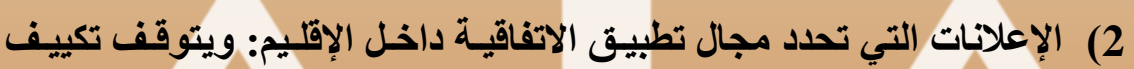

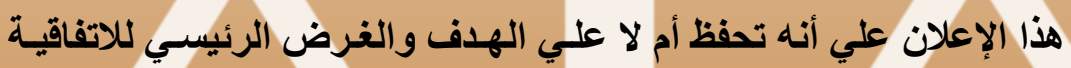

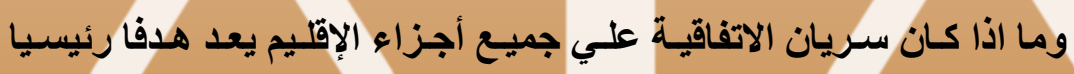

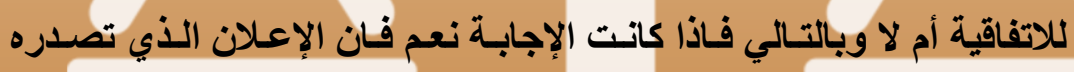

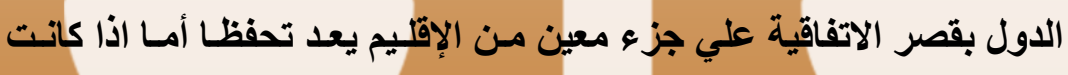
الإجابة بلا فلا يعد تحفظا وانما اعلانا يحدد مجال انطباق الاتفاقية.

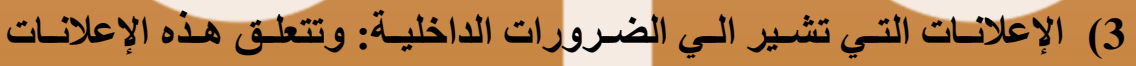

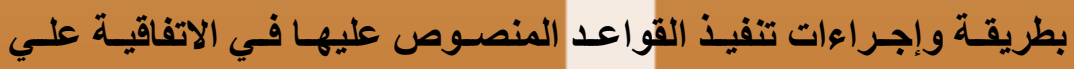
الصعيد الوطني. 4) إعلانات السياسة الدولية: ويلاحظ على بعض الدئ الدول أنها تصدار إعلانـات

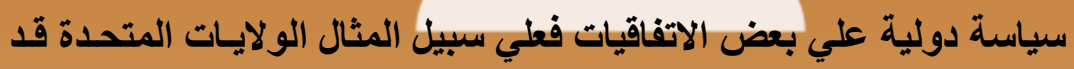

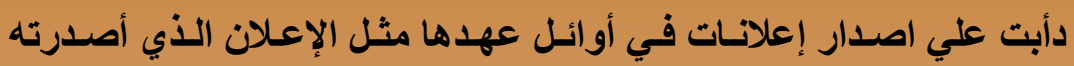

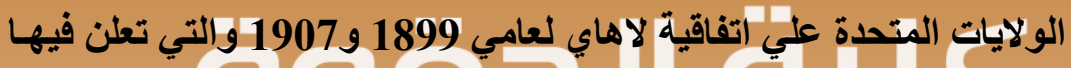

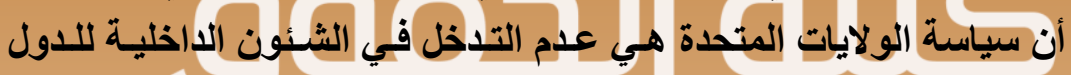
الأجنبية.

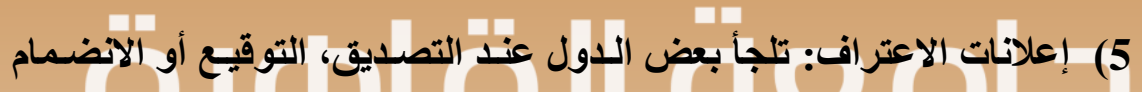

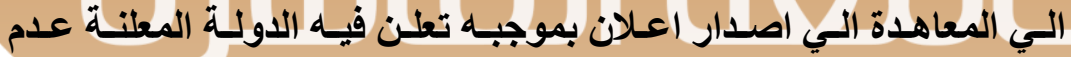

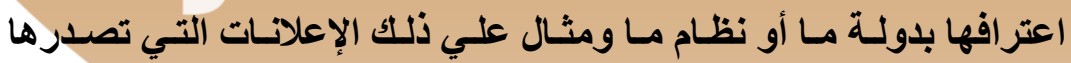

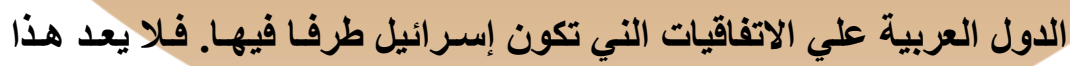

(1) Frank Horn, Reservations and interpretative declarations to multilateral treaties, op. cit.; p. 98-107 
الإعلان تحفظـا نظرا لان التحفظ يغيـر أو يسد تبعد تطبيق قاعدة معينـة أم

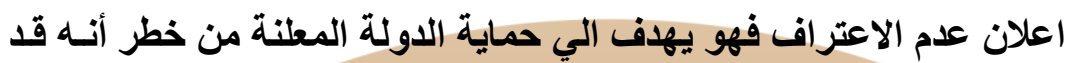

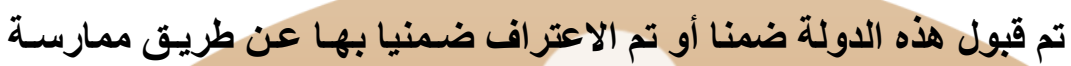
علاقات تعاقدية من خلال الاتفاقية. 1

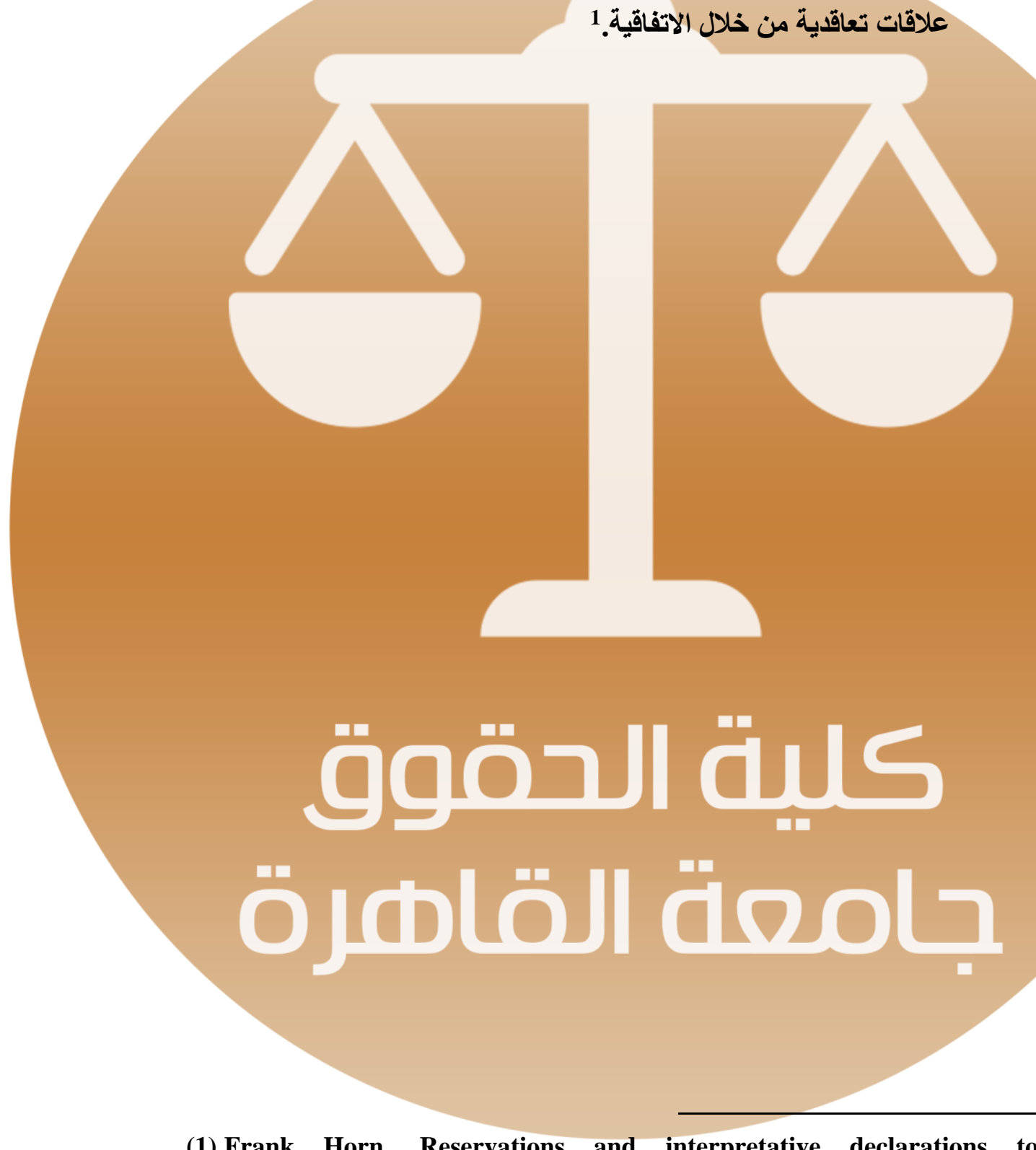

(1) Frank Horn, Reservations and interpretative declarations to multilateral treaties, op. cit.; p. 98-107 


\section{النصل الثالث}

\section{التطبيقات المثتلفة لاتمنظات المسترة}

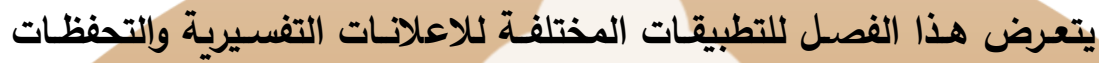

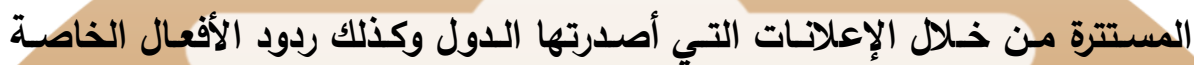

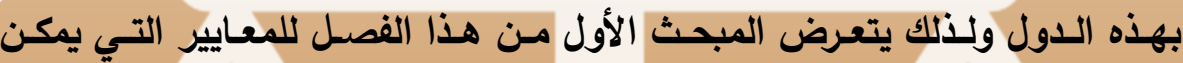

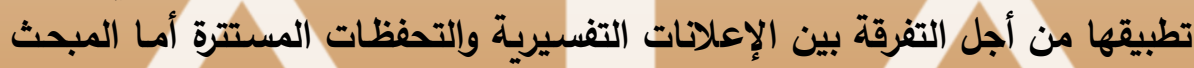

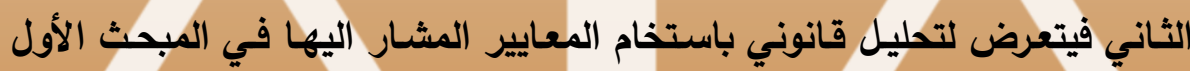

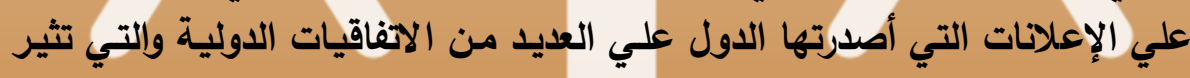

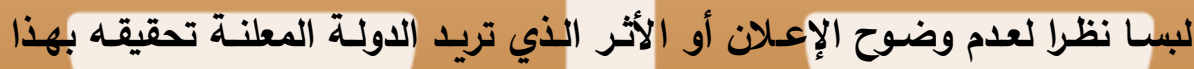

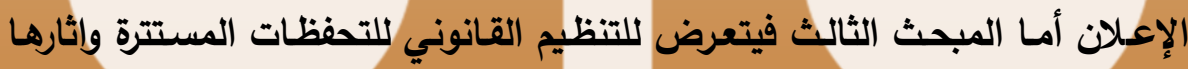

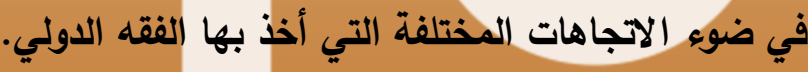

\section{الإبمث الاول}

\section{المعايير واجبة التطبيق التفرقة بين التمفظات الستترة والإعلانات التفسيرية}

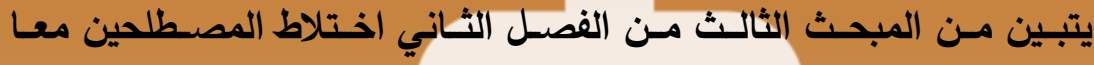

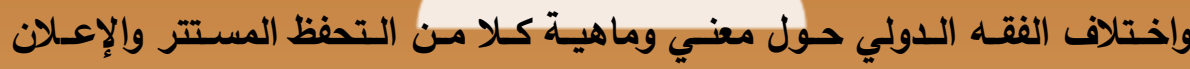

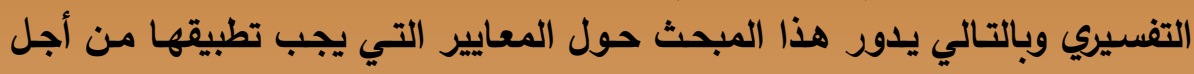
الكثف عما إذا كان الإعلان الصادر عن الدولة تحفظا مقستترا أم اعلانا تفسيريا.

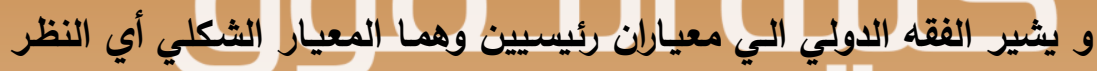

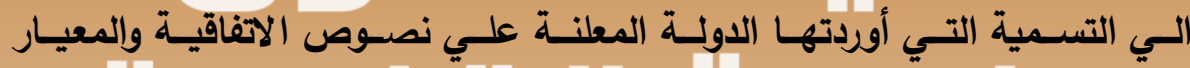

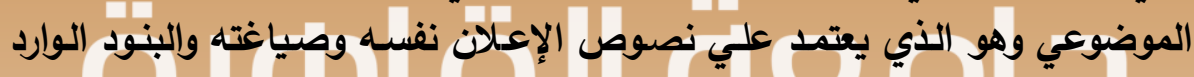

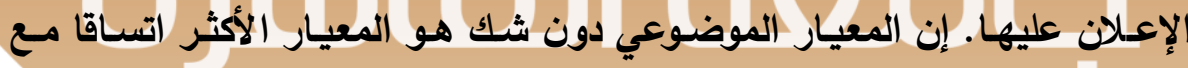

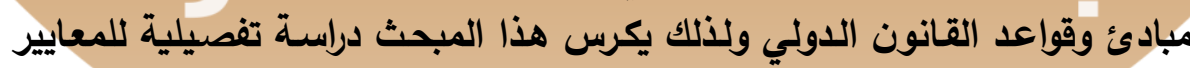
الموضوعية التي قال بها الفقه الدولي.

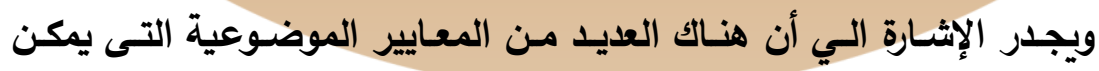

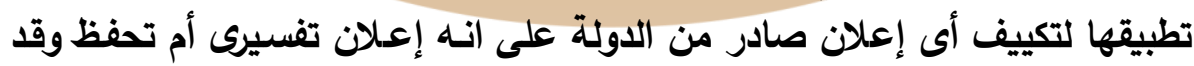


اشـارت لجنـة القـانون الــولي الـي عـدة معـايير للتفرقـة بـين الاعـلان التفسيري والتحفظات ومنها المعياران التاليان: 1 1- تحليل الههف او الغرض من هذه الإعلانات. 2- تحليل للإعلانات نفسها وصياغتها.

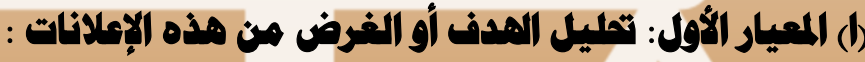

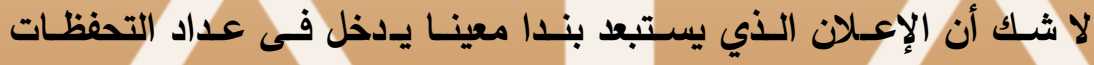

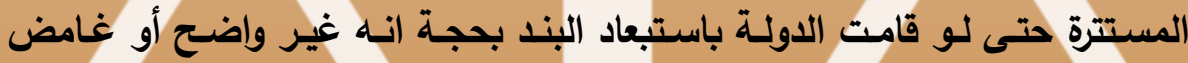

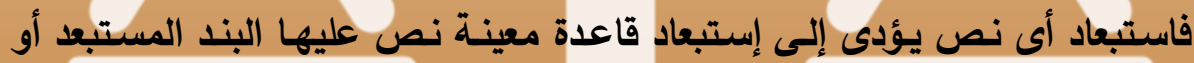

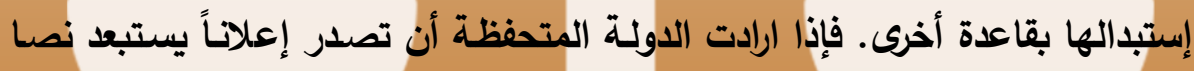

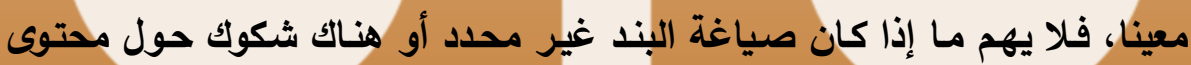

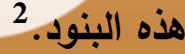

و قد تناولت لجنة القانون الدولي إثكالية التفرقة بين الإعلانات التفسيرية

والتحفظات وقد استعرضت في المبدأ التوجيهي رقم 1.3 .1 ذلك على النحو التالي:

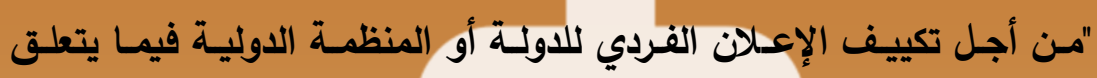

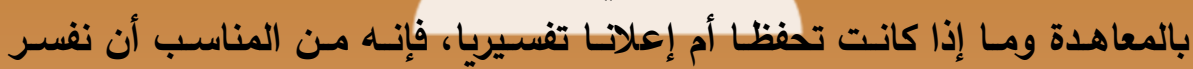

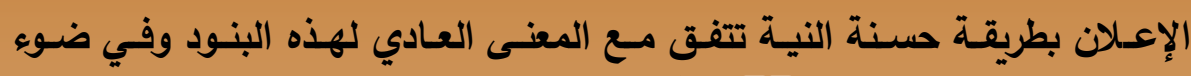

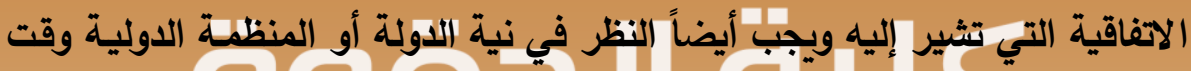
$\longrightarrow$ (1)

(1) To determine whether a unilateral statement formulated by a state or an international organization in respect of a treaty is a reservation or an interpretative declaration, it is appropriate to interpret the statement in good faith in accordance with the ordinary meaning to be given to its terms, in light of the treaty to which it refers. Due regard shall be given to the intention of the state or the international organization concerned at the time the statement was formulated. ILCYB: 2007 paragraph 1.3.1 p. 49.

(2) Ruda, Reservations to treaties, op. cit., p. 106). 


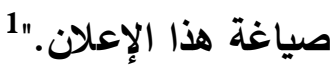

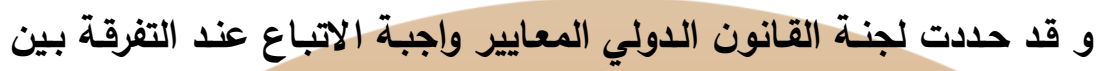

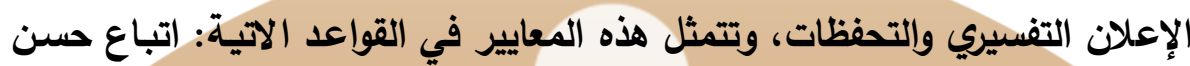

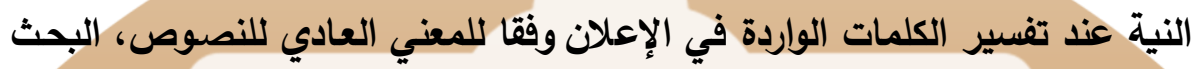
في نية الدولة أو المنظمة الدولية التي تقوم بصياغة هذا الإعلان.2

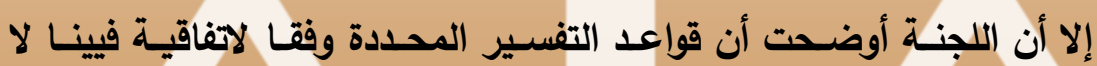

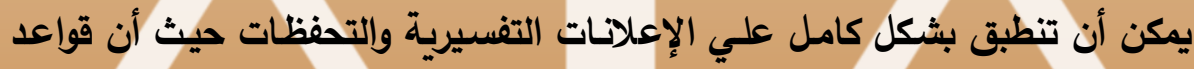

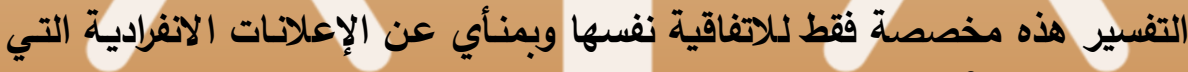

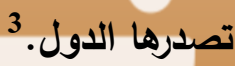

و يثور السؤال حول ماهية المعيار الواجب تطبيقه في التفرقة بين الإعلان

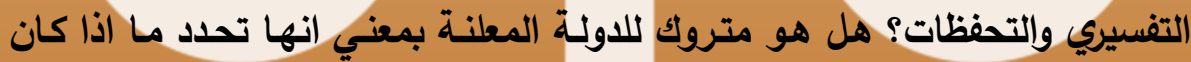
الاعلان يعد اعلانا تفسيرياً أو تحفظاً؟

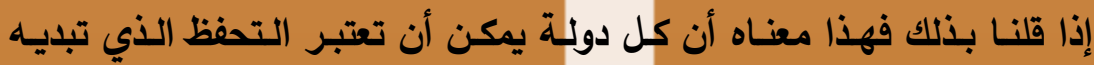

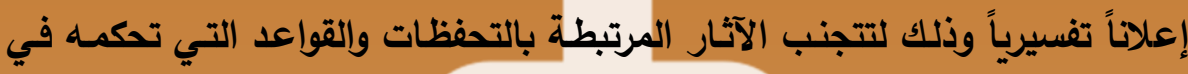

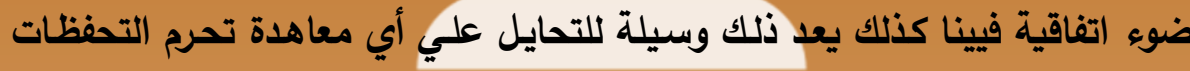

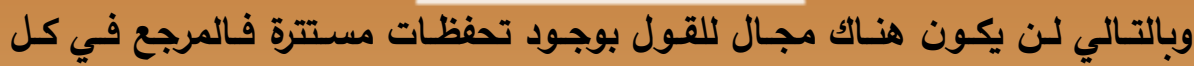
الأحوال يكون تكييف الدولة نفسيال لهذال لـول الاعلان.

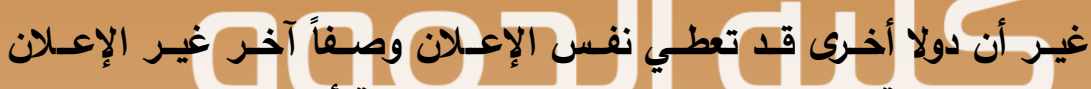

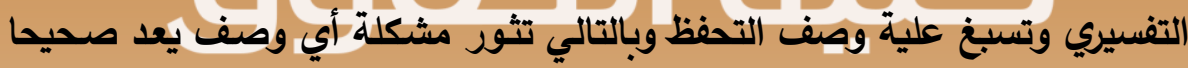

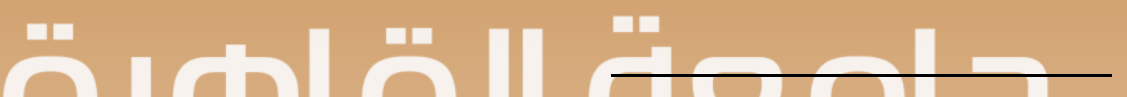

(1) International law commission report, 1999 v. II pt. 2 U.N.Y.B. Int'l L.

Commn 105 (1999) paragraph ((the character of a unilateral statement as a reservation or an interpretative declaration is determined by the legal effect it purports to produce) 1.3.1 p. 49.

(2) 1999 Report (A/54/10), 253-4

(3) Id.

(4) International law commission report, 1999 v. II pt. 2 U.N.Y.B. Int'l L. Commn 105 (1999) paragraph 1.3.1 p. 49. 
كما ان البحث في نيـة الدولـة المعلنة يثير صعوبات بالغة وذلك في حالـة اقتـاع الدول الأخرى بأن هذا الإعلان هو تحفظ مستتر في حقيقة الامر. 1

لذلك فإن المعيار الموضوعي المتمثل في بحث تأثير الإعلان على المعاهدة

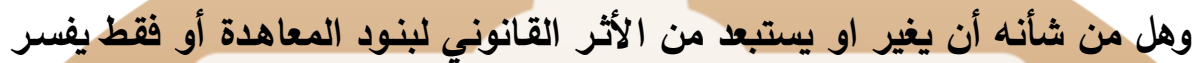

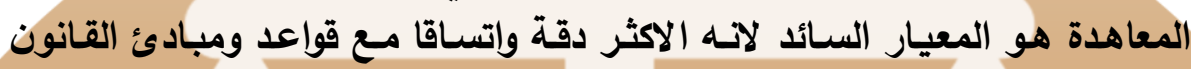

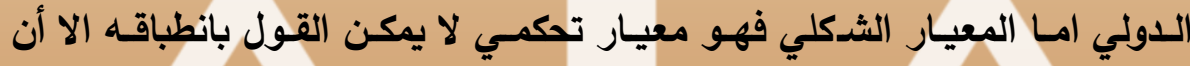

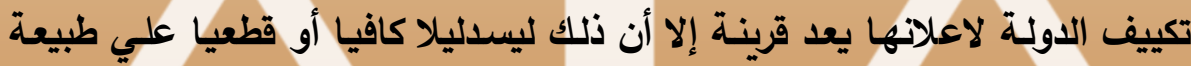

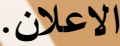
وقد اقترحت لجنـة القـانون الدولي اسـخدام مسـلك تفسيري مشـابه للجزي

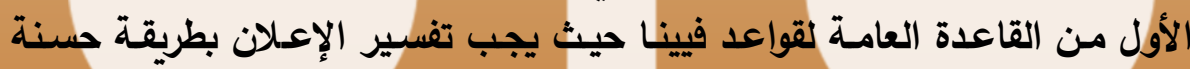

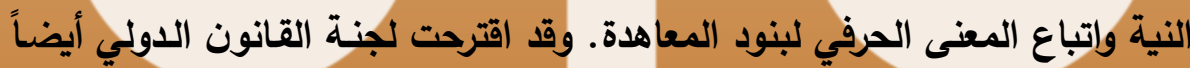

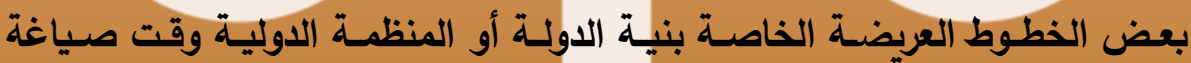

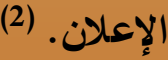

وبذأك يمكن التحري والبحث في الأعمال التحضيرية والمناقشـات البرلمانية

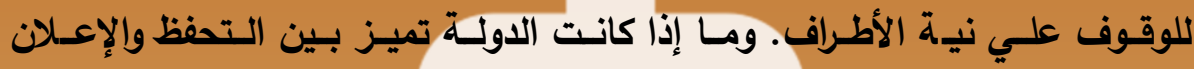

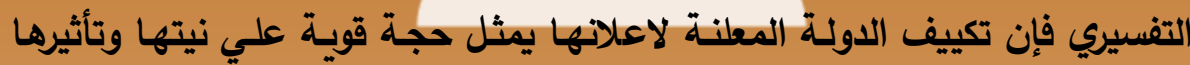

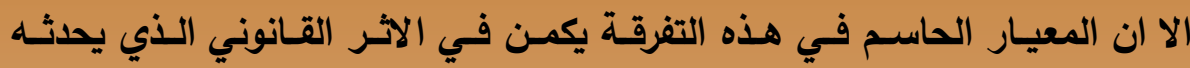
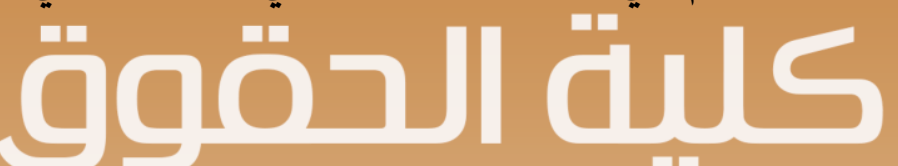

(1) International law commission report, 1999 v. II pt. 2 U.N.Y.B. Int’l L. Commn 105 (1999) para. 4.

(2)"To determine whether a unilateral statement formulated by a state or an international organization in respect of a treaty is a reservation or an interpretative declaration, it is appropriate to interpet the statement in good faith in accordance with the ordinary meaning to be given to its terms, in the light of the treaty to which it refers. Due regard shall be given to the intention of the state or the international organization concerned at the time the statement was formulated." International law commission report, 1999 v. II pt. 2 U.N.Y.B. Int'I L. Commn 105 (1999). 
الاعلان التفسيري.1

وقد أشـار الفقيه McRae إلى ضرورة التفرقة بين التحفظـات والإعلانـات

التفسيرية البسيطة وأنه يجب النظر الي سؤالين: السؤال الأول: هل الإعلان نفسئه

يهدف إلى تفسير البند فقط أم أنه يستهدف تعديل أو تحديد بنود المعاهدة ؟ (2) أما السؤال الثاني فهو: هل اشترطت الدولـة المعلنة للانضمام إلى المعاهدة

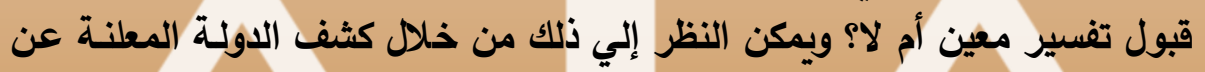

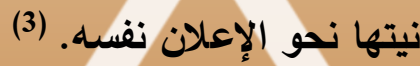

فبالنسـبة للسـؤال الأول فقــ عـرض الموضـوع على محكمـة التحكيم التي

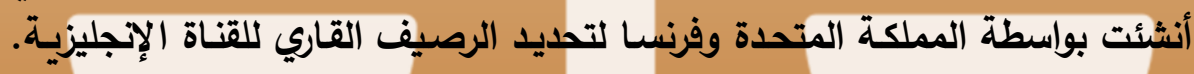

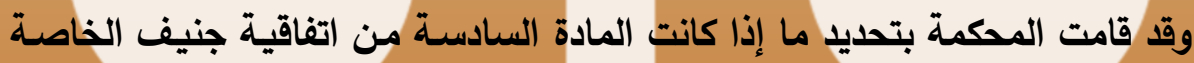

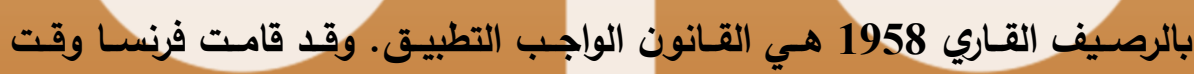

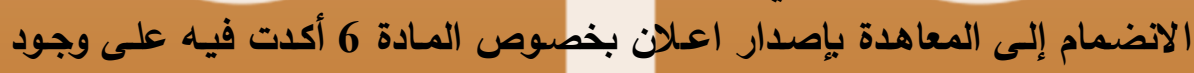

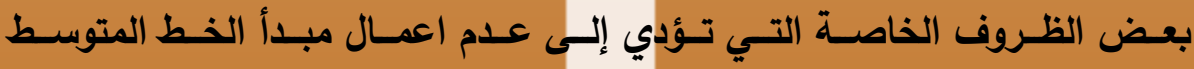
equidistance

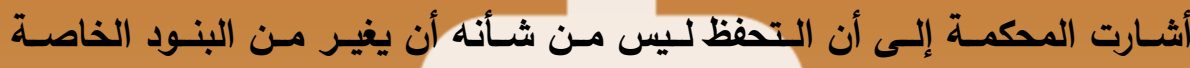

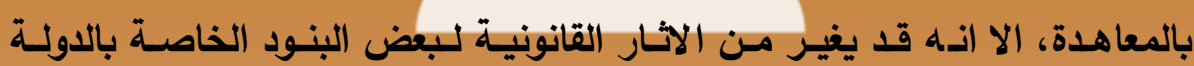
المتحفظة.

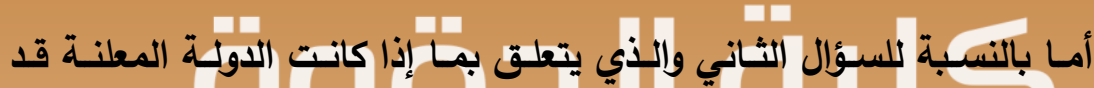

(1) International law commission report, 1999 v. II pt. 2 U.N.Y.B. Int'l L. Commn 108 (1999).

(2)McRae, The legal effect of interpretative declarations, op. cit., p.161162.

(3)Loc. Cit.

(4) International law commission report, 1999 v. II pt. 2 U.N.Y.B. Int'l L. Commn 105 (1999) paragraph 12 (citing case concerning the delimitation of the continental shelf between the United Kingdom of Great Britain and Northern Ireland and the French Republic, decision ol 30 June 1977). 


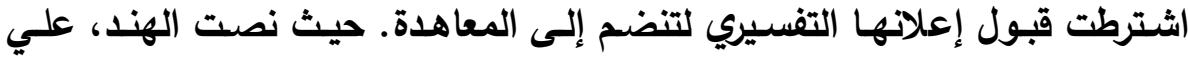
سبيل المثال، في المعاهدة الخاصـة بالمنظمـة الدولية للتشـاور البحريـة (IMCO)

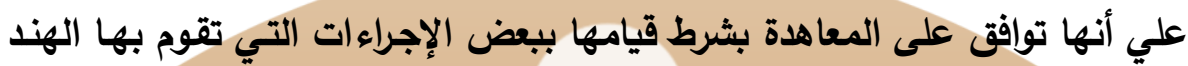

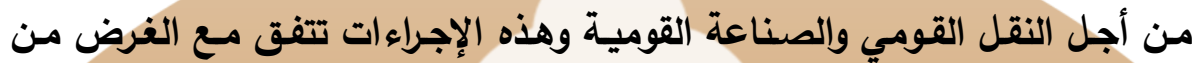

الاحفاقية. (1) اجل النقل

ولذلك أثير السؤال حول ما إذا كان الإعلان الهندي بمثابة تحفظ أو إعلان

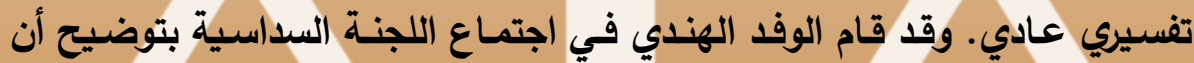

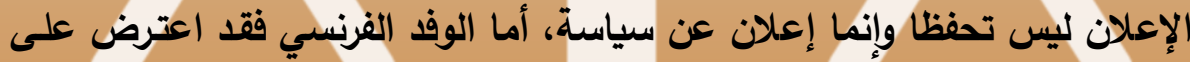

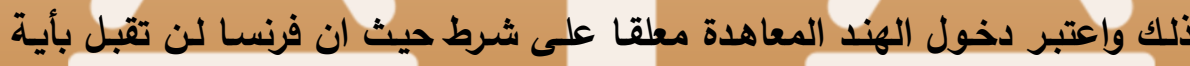

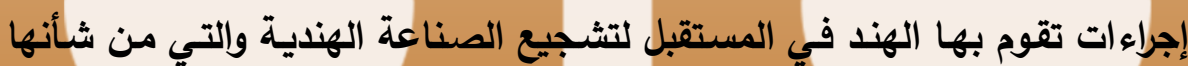
أن تتعارض مع الغرض من الاتفاقية.2

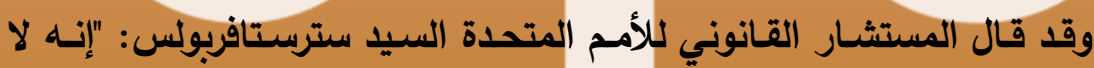

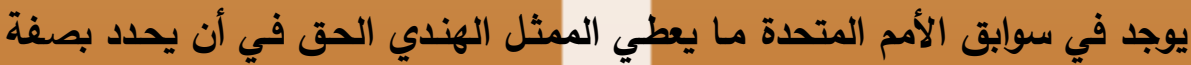

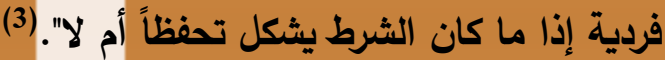

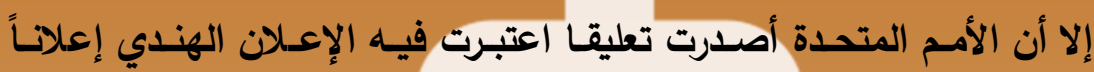

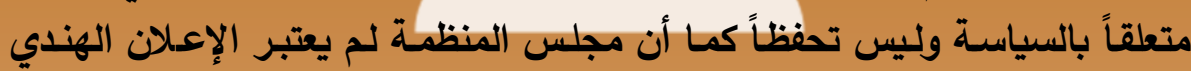
تحفظاً أيضاً. وقد حلـل McRae الإعلاتـات الهنديـة بقوبه :ان النظر في هذا الإعلان

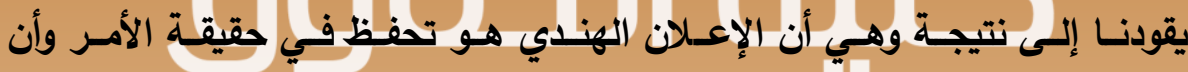
الاعتراض الفرنسي صحيح.

(1) United Nations Treaty Collection.

(2) Frank Horn, Reservations and interpretative declarations, op. cit., p. 190.

(3)International law commission report, 1999 v. II pt. 2 U.N.Y.B. Int'l L. Commn 105 (1999) paragraph 12.

(4)International law commission report, 1999 v. II pt. 2 U.N.Y.B. Int'l L. Commn 105 (1999) paragraph 12.

(5) McRae, The legal effect of interpretative declarations, op. cit., p. 165-6. 
أمـا البعض الاخـر مـن الفقـه الـذي يعتبر الإعـلان الهنـدي مجـرد إعـلان

$$
\text { تفسيري فنلك يرجع إلى واحد من أمرين: }
$$

الأمر الأول: أن الإعلان اللاحق من الهند واللذي أكد فيه على أن الإعلان

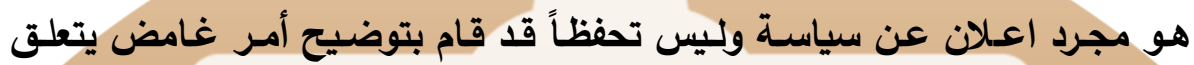
بوثيقة القبول.

والأمر الثاني: أن الإعلان اللاحق يمنع الهند من أن تصاول أن تستخدم هذا

الإعلان فيما بعد كتحفظ. (1)

ولكن هل يمكن اعتبار ذلك بمثابة اعطاء سلطة تعديد ما إذا كان الإعلان

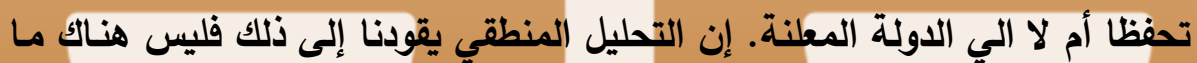

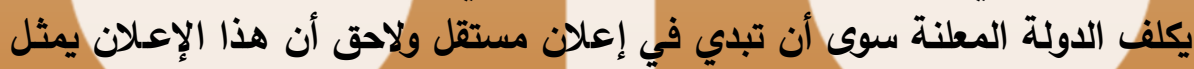
إعلانا تفسيريا وليس تحفظا.

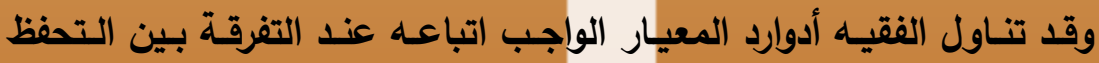

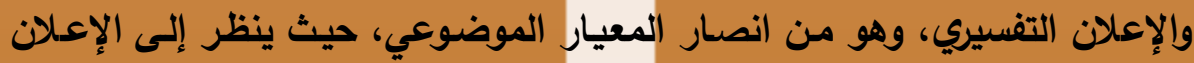

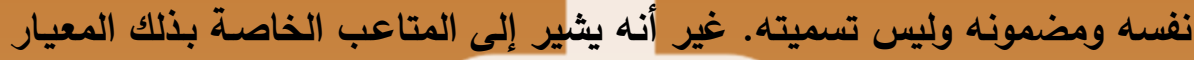

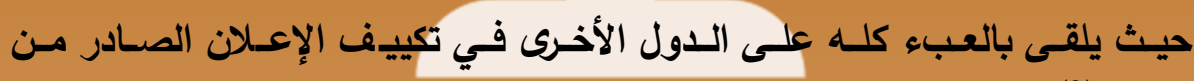
(2) الدولة.

وبضـرب الفقيـه أدوارد مثـالين على حكمين لمحكمـة التحكيم بـين فرنسـا

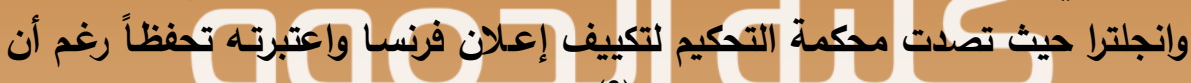

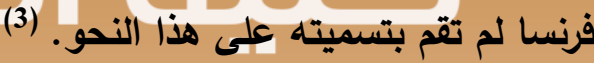

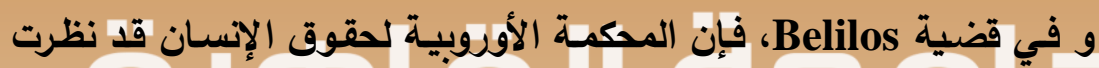

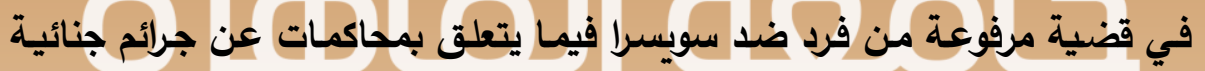

(1)Loc. Cit.

(2) Edward, Reservation to treaties, 10 Mich. J. Int iL. 369 (1989); See also D.W. Bowett, Reservations to non-restricted multilateral treaties, the British Year Book of International Law, 1976-77 (forty eighth year of issue) at p. 68.

(3)Loc. Cit. 
أمسام مجلس الثـرطة مـع الحق في الاسـتئناف أمسام محكمـة عاديـة. وقــ قامـــ Belilos

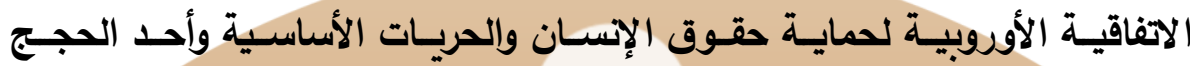

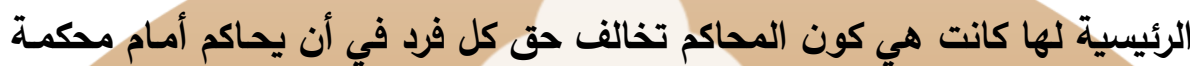
عادلة ومستقلة. أما الحكومة السويسرية فقد أكدت على أنها قد أصدرت تحفظاً على المـادة

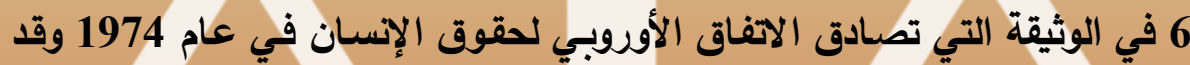

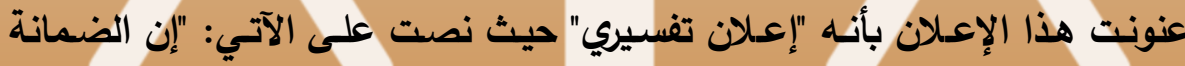

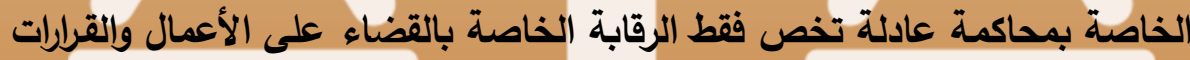

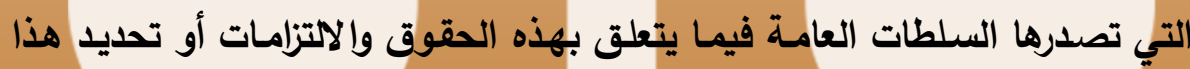

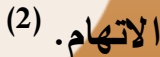

وقد دفعت Belilos بأن الإعلان ليس إلا إعلانـا تفسيريا ولا يعد تحفظاً.

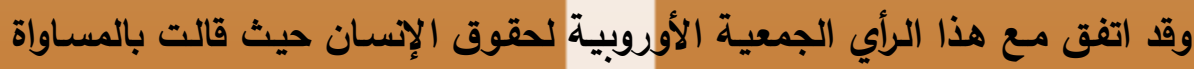

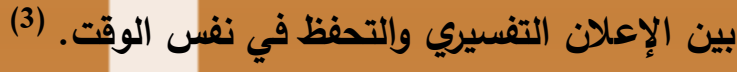

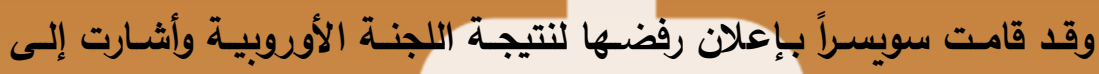

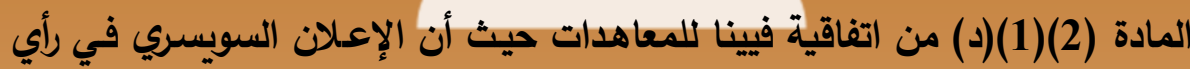
المحكمة يعد تحفظاً. (4) المنادة (1) المات

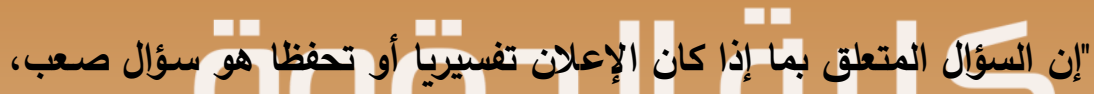

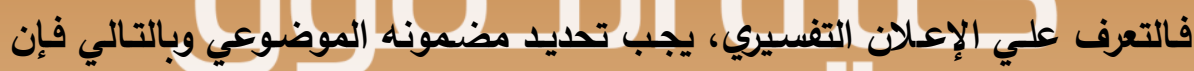

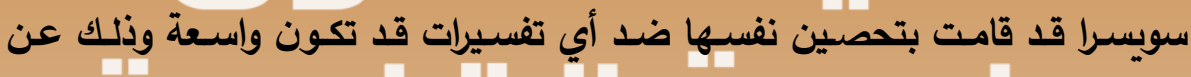
$(3)$
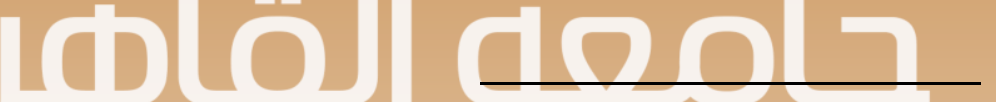

(1)Henry J. Bourguignon, The Belilos case: new light on reservations to multilateral treaties, 29 Va. J. Int'l L. 347 (1988-89).

(2) Loc. Cit.

(3) Loc. Cit. (citing 132 Eve. Ct. H.R. (cer. A), 10 Evc. Human Rights Rep. 466 (1988).

(4)Loc. Cit. (citing 132 Eve. Ct. H.R. (cer. A), 10 Evc. Human Rights Rep. 466 (1988).Belilos juolgrent, parags 49). 
طريق هذا الإعلان. (1)

وبالتالي يلاحظ أن المحكمة هنا كيفت إعلان سويسرا على أنـه تحفظ رغم

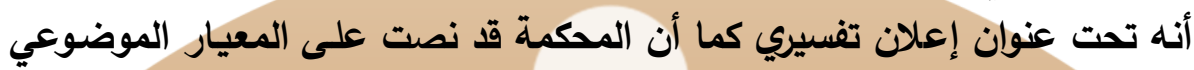

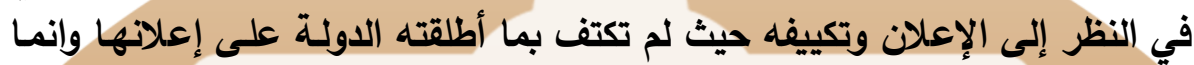
قامت بتحليل ودراسة مضمون الإعلان نفسه.

لذلك فهناك فتخ قانوني أشارت إليه قضية Belilos، وهي أن تقوم الدولة أنة

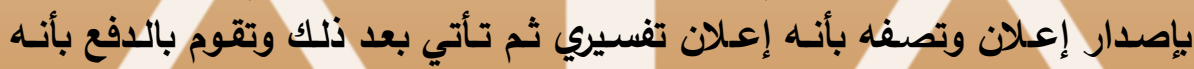

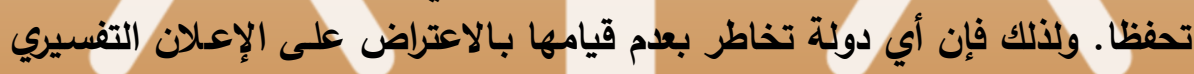

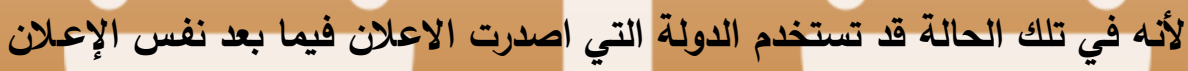
كتحفظ وذلك في فترة لاحقة.

وقدا أوضـت المملكة المتحدة ذلك في اعتراضهها على إعـلان يوجوسـلافيا

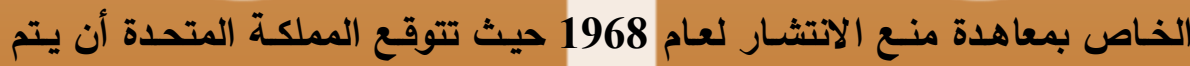
تحويل هذا الإعلان إلى تحفظ وبالتالي تحتفظ بحقها في الاعتراض على على الإعلان التفسيري.

أمـا المعيار الثكلي والذي يقوم على الأخذ بالتسمية التي أطلقتها الدولـة

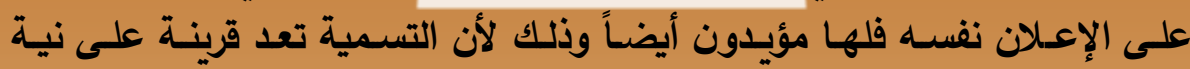
الاولة التي أصدرت الإعلان. (2)

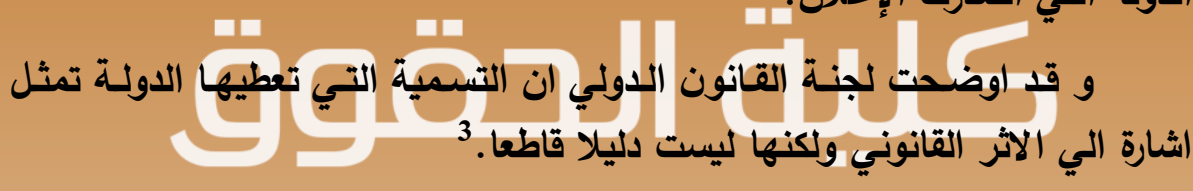
$(0)(0)+20$

(1) Loc. Cit.

(2) Richard Edwards, Reservation to treaties, op. cit., p. 373.

(3) International law commission report, 1999 v. II pt. 2 U.N.Y.B. Int'l L. Commn 105 (1999). The phrasing or name given to a unilateral statement provides an indication of the purpoted legal effect. This is the case in particular when a state or an international organization formulates several unilateral statements in respect of a single treaty and 
وأثناء مؤتمر فيينا، فإن سير واللدوك قد أشـار إلى أهمية المعيار الثكلي

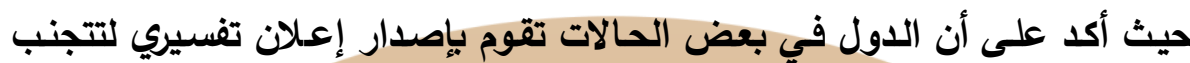

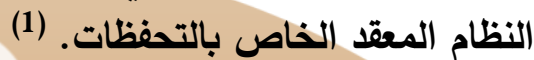

أمـا السـير سـينكلير وبويـت فقــ اعترفـا بـأن الوصـف الـذي تلحقـهـ الاولـة

بإعلانها يجب أن يحكم تكييف الاعلان التفسيري.

وينكر Edward على الإعلانات التفسيرية أي تأثير قانوني نظراً لأنه ليس

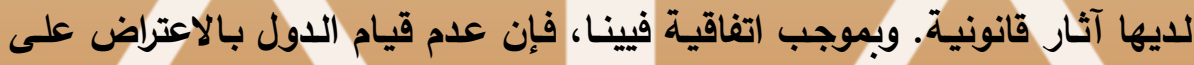

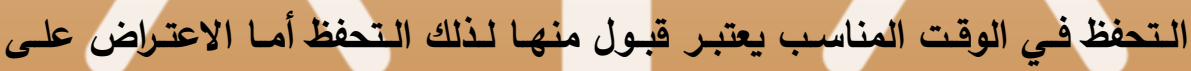

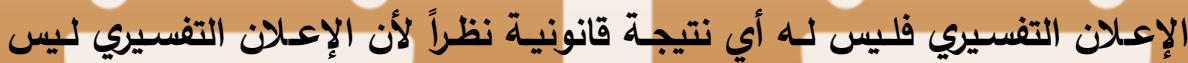

اما لجنة القانون الدولي فقد اثـارت الي ان المعيار الثكلي ليس لاه الهمية

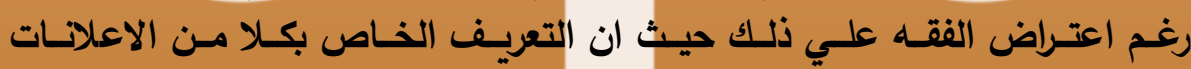

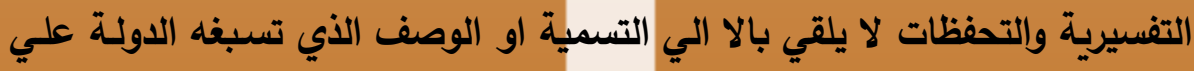

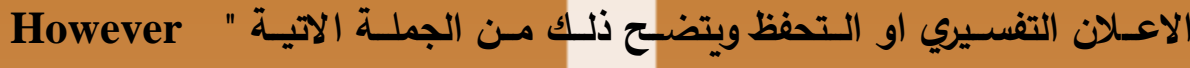
${ }^{4}$ phrased or named و بتطبيق المعيار الموضوعي علي بعض الإعلانات يمكن عرض الإعلانـات

الاتية:

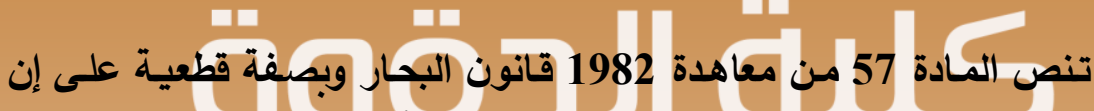
الإطار الخارجى للمنطقة الإقتصادية الحصرية لايمكن أن تزبـا على 200 ميل من designates some of them as reservations and others as interpretative declarations.

(1) D.W. Bowett, Reservations to non-restricted multilateral treaties, 48 Brit. V.B. Int'l L. 67, 69 (1976-77).

(2) Loc. Cit.

(3) Richard Edwards, Reservation to treaties, op. cit., p. 373.

(4) International law commission report, 1999 v. II pt. 2 U.N.Y.B. Int'l L. Commn 105 (1999). 
الخط الذى يحسب على أساسه عرض البحر الإقليمى "1"

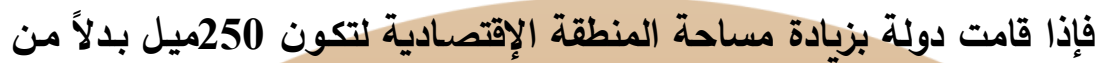

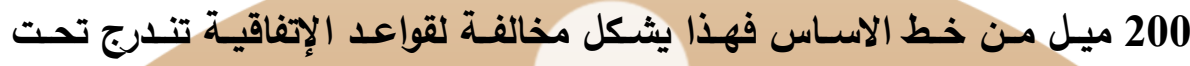

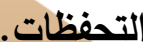

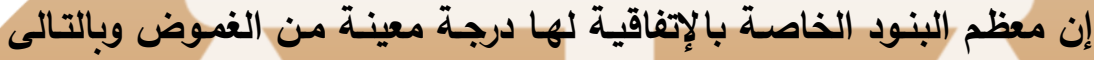

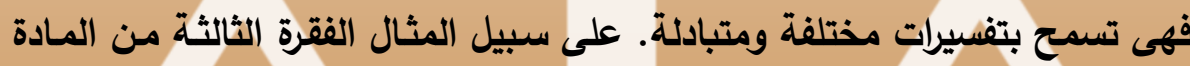
121 من معاهدة البحار التى تنص على :

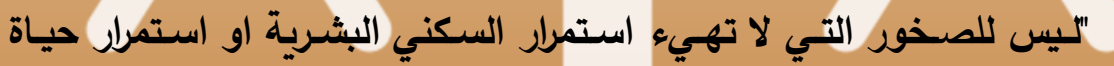

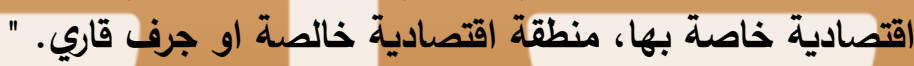

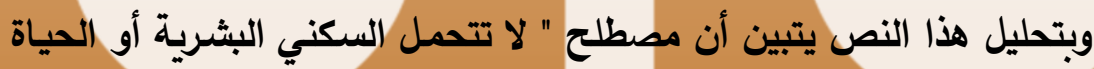

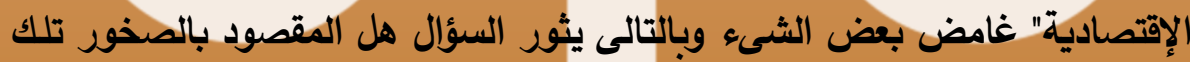

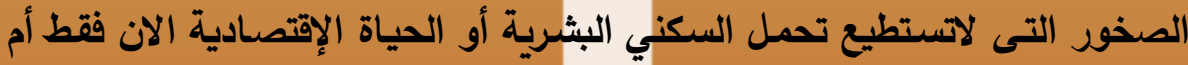

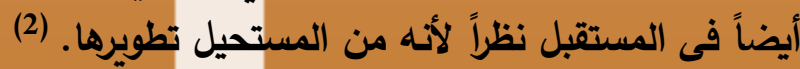

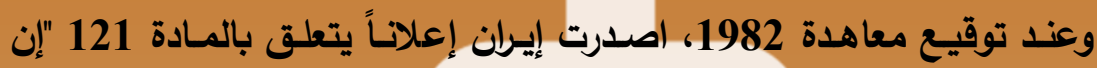

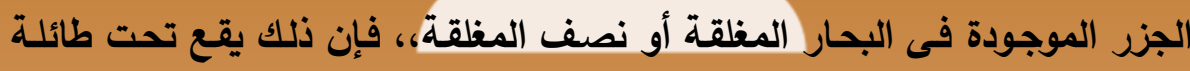

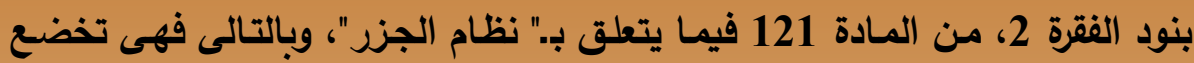

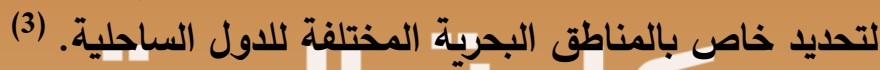

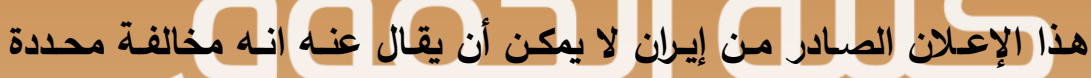

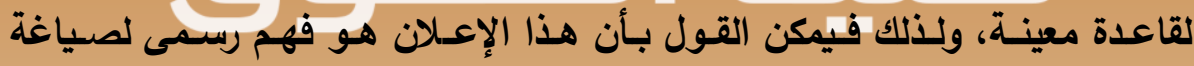

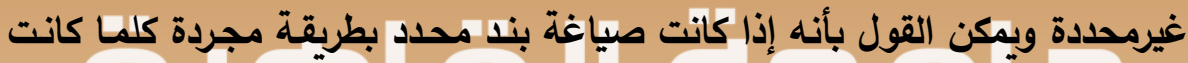

(1) United Nations Convention on the law of the Sea.

(2)United Nations Treaty

Collection,http://treaties.un.org/Pages/ViewDetailsIII.aspx?\&src=TRE $\underline{\text { ATY \&mtdsg_no=XXI } \sim 6 \& \text { chapter }=21 \& T e m p=\text { mtdsg } 3 \& \text { lang }=e n}$

(2) United Nations Treaty collection, http://treaties.un.org/Pages/ViewDetailsIII.aspx?\&src=TREATY\&mtds g_no=XXI $\sim 6 \&$ chapter $=21 \&$ Temp $=$ mtdsg $3 \&$ lang $=$ en 
الفرص متزايدة للقول بأن الإعلان تفسيرى. (1)

على سبيل المثال فإن المـادة (1) من الميثاقين الخاصيين بالأمم المتحدة

لحقوق الإنسان تعطى الحق فى تقرير المصير الا انها مصاغة صياغة مطاطة للغاية علي النحو التالي:

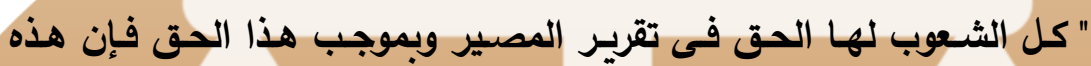

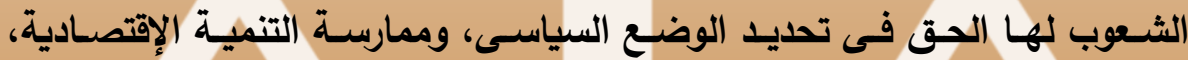

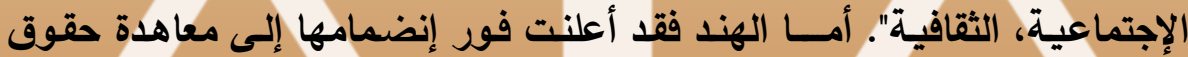

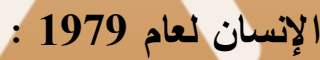

وجاء الإعلان الهندي لينص علي أن مصطلح "الحق فى تقرير المصير"

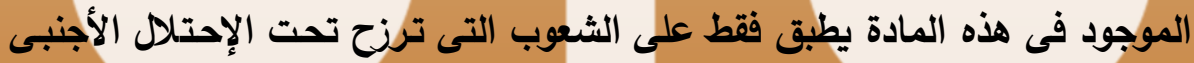

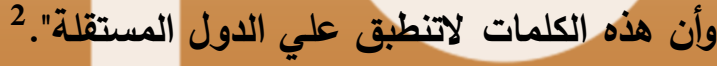

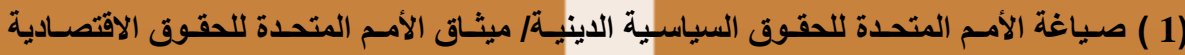
الاجتماعية والثقافية (المادة 1).

(2)

United

Nations

Treaty

Collection,

http://treaties.un.org/Pages/ViewDetails.aspx?src=TREATY\&mtdsg_no =IV-3\&chapter $=4$ \&lang=en\#EndDec

"I. With reference to article 1 of the International Covenant on Economic, Social and Cultural Rights and article 1 of the International Covenant on Civil and Political Rights, the Government of the Republic of India declares that the words 'the right of self-determination' appearing in [this article] apply only to the peoples under foreign domination and that these words do not apply to sovereign independent States or to a section of a people or nation--which is the essence of national integrity.

"II. With reference to article 9 of the International Covenant on Civil and Political Rights, the Government of the Republic of India takes the position that the provisions of the article shall be so applied as to be in consonance with the provisions of clauses (3) to (7) of article 22 of the Constitution of India. Further under the Indian Legal System, there is no enforceable right to compensation for persons claiming to be victims of unlawful arrest or detention against the State. 
وقد إعترضت كل من فرنسا وألمانيا وهولندا على الإعلان الهندى على الرغم من إعتبارهم اياه بمثابة إعلان تفنيرى.

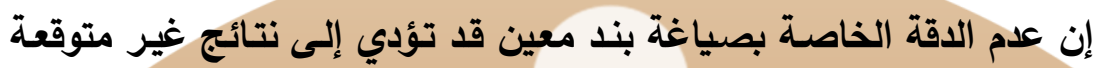

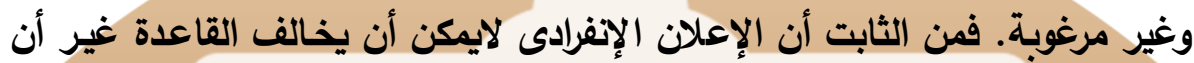

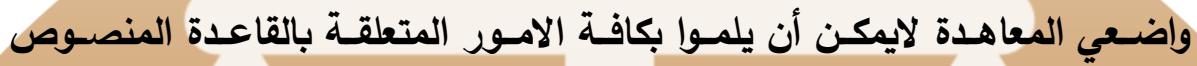
عليها.

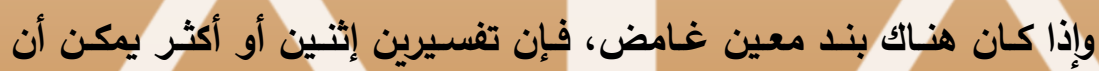

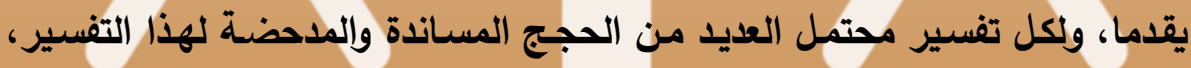

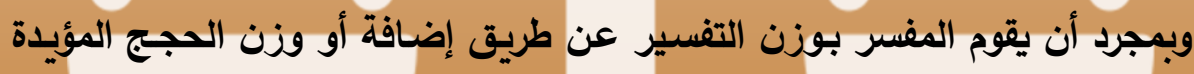

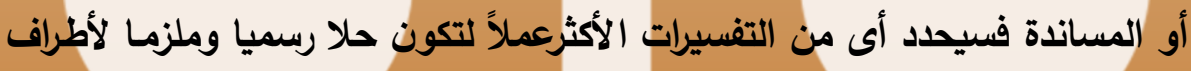
الإحفاقية.

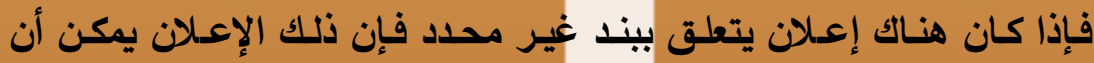

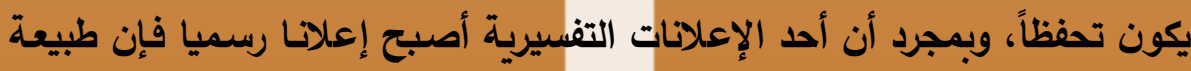

"III. With respect to article 13 of the International Covenant on Civil and Political Rights, the Government of the Republic of India reserves its right to apply its law relating to foreigners. "IV. With reference to articles 4 and 8 of the International Covenant on Economic, Social and Cultural Rights, and articles 12, 19 (3), 21 and 22 of the International Covenant on Civil and Political Rights the Government of the Republic of India declares that the provisions of the said [article] shall be so applied as to be in conformity with the provisions of article 19 of the Constitution of India. "V. With reference to article 7 (c) of the International Covenant on Economic, Social and Cultural Rights, the Government of the Republic of India declares that the provisions of the said article shall be so applied as to be in conformity with the provisions of article 16(4) of the Constitution of India."

(1) United Nations Treaty Collection, http://treaties.un.org/Pages/ViewDetails.aspx?src=TREATY\&mtdsg_no $=$ IV-3\&chapter $=4 \&$ lang=en\#EndDec 
الإعلان تكون قد حسمت.

والإعلان قد يكون رسميا ونافذا وذلك من أجل إلزام أطراف المعاهدة بمجرد

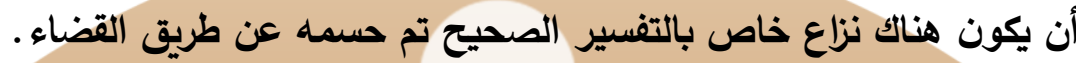

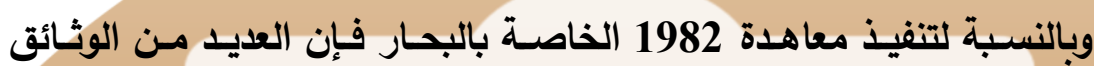

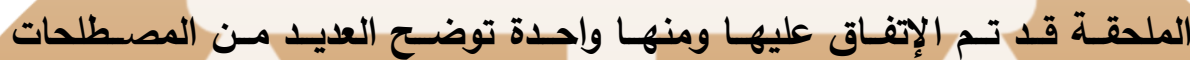

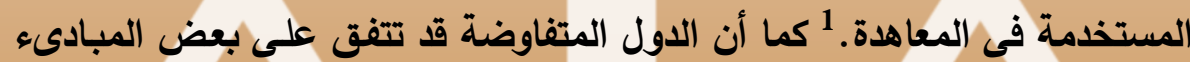
العامة المهمة عند تطبيق بنود مختلفة بالمعاهدة.

والفهـم المشترك يمكـن اعتناقـه، مثـال ذلـك معاهـدة 1978 الخاصــة بنقـل

البضائع عن طريق البحر فى مؤتمر بهامبورج.

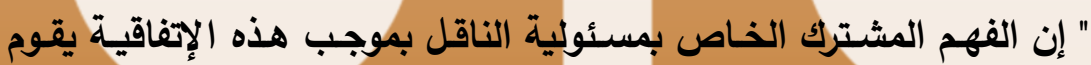

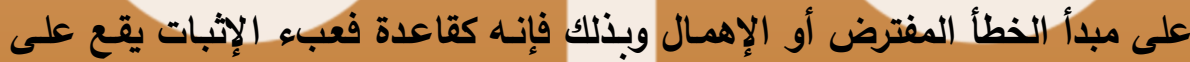

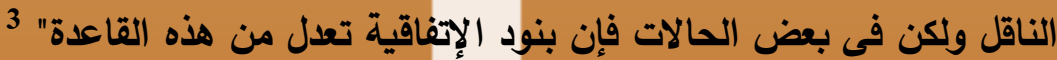
وتعد الإعلانات التفسيرية المساندة للملاحق أو البروتوكولات لها نفس القوة

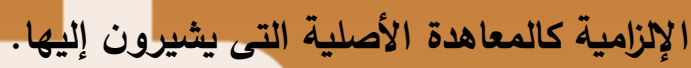

إذا كان الإعلان يستهذف استبعاد تطبيق نص معين فهذا تحفظ مستتر دون

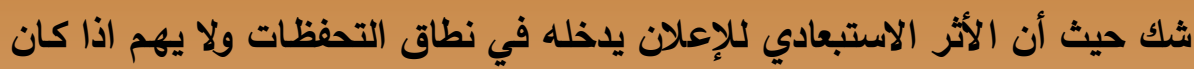

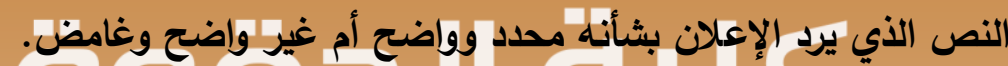

(1) 1 United

Nation

Treaty

Collection, http://treaties.un.org/Pages/ViewDetailsIII.aspx?\&src=TREATY\&mtds g_no=XXI $\sim$ \& \&chapter $=21 \&$ Temp $=$ mtdsg3\&lang=en

(2) United

Nations

Treaty

Collection., http://treaties.un.org/Pages/ViewDetailsIII.aspx?\&src=TREATY\&mtds g no=XXI 6\&chapter $=21 \&$ Temp $=$ mtdsg3\&lang $=$ en

(3) "It is the common understanding that the liability of the carrier under this convention is based on the principle of presumed fault or neglect. This means that, as a rule, the burden of proof rests on the carrier but, with respect to certain cases, the provision of the convention modify this rule." 
أما الإعلان الذي يهدف الـي تعديل النص أو القاعدة القانونيـة فهو أصعب

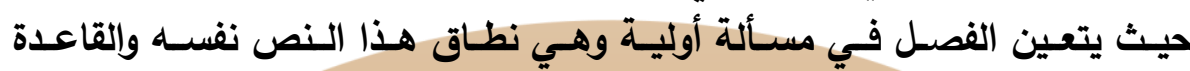
القانونية.

إن النصوص التي تأتي واضحة في نطاقها تسهل من تكييف الإعلان ومـا

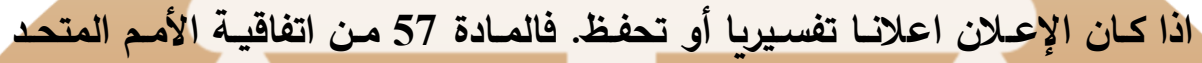

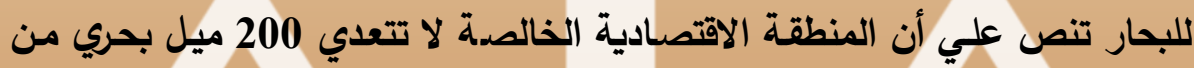
خط الأسـاس وبالتالي اذا أصدرت احدي الدان الدول العلانـا يجعل المنطقة الاقتصـادية

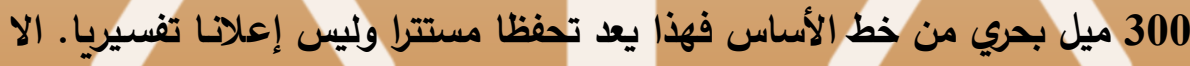

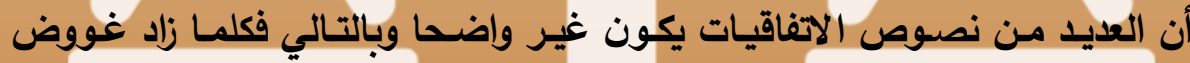

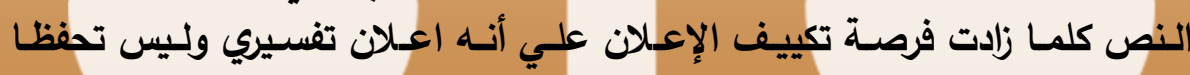
مستترا.

علي أن الفقيه الدولي هورن يري أنه في حالة النص الغامض والذي شهر

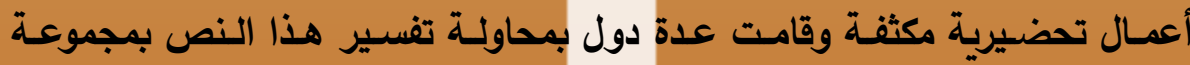

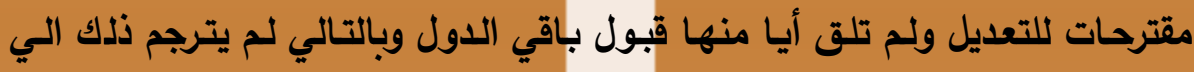

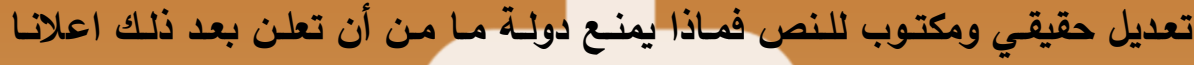

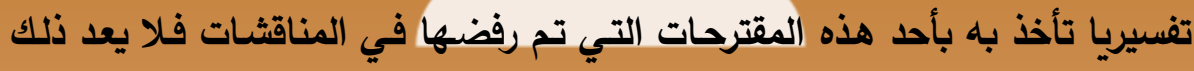

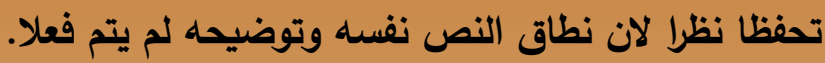

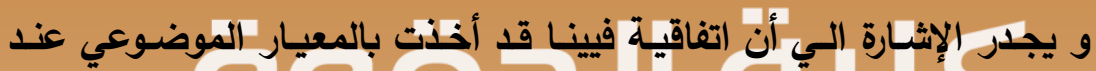

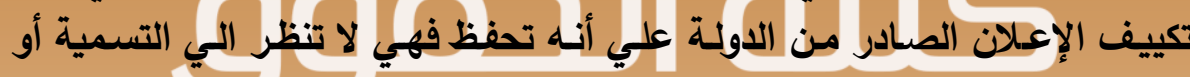
الصياغة التي استخدمتها الدولة أو كيفية وصفها لهذا الإنها الاعلان. 1

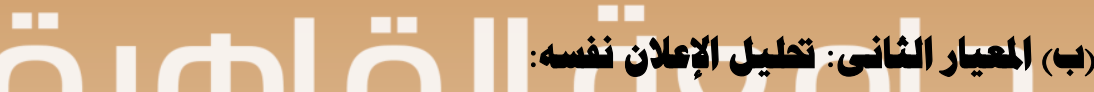
إن المعيار الأول قـ ركز على أثار الإعـلان نفسـهـ الا إن طبيعـة الإعلان

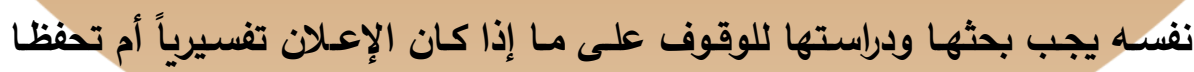

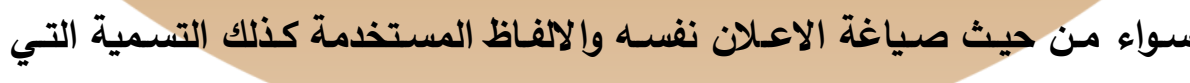

(1) Frank Horn, Reservations and interpretative declarations to multilateral treaties, op. cit.; p. 236 
تطلقها الاول علي الاعلان نفسه.

فطريقة صياغة الإعلانات نفسها لها أهمية حيث أن الدول الاخري قد تفسر

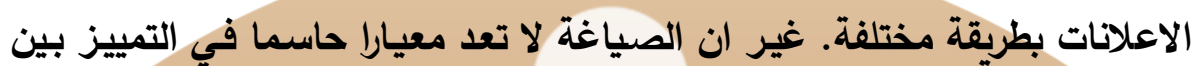

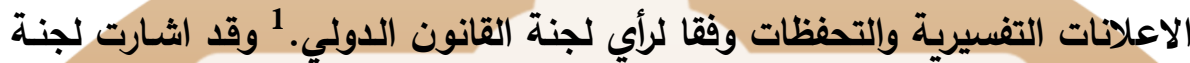

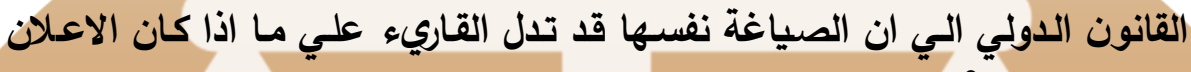
مشروطا ام لا.

ولذلك فيمكن التمييز بين إعلانات السياسـة والتحفظات المستترة وذلك فيما

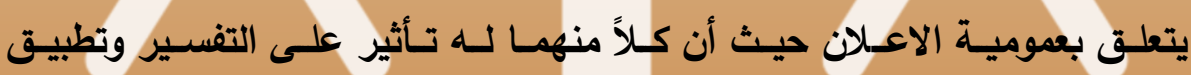

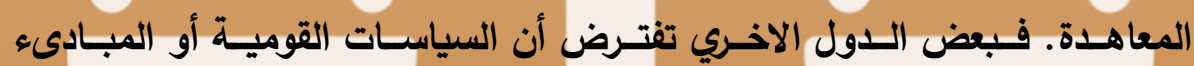

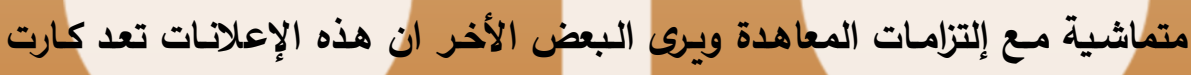

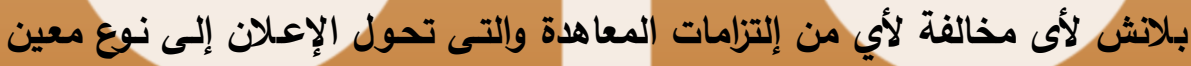

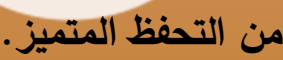

وقد قامـت حكومـة الهند بالتصديق على معاهدة 1941 الخاصـة بالمنظمـة

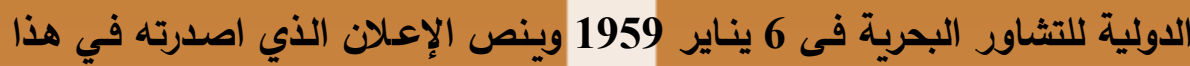

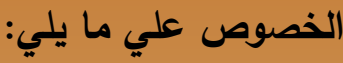

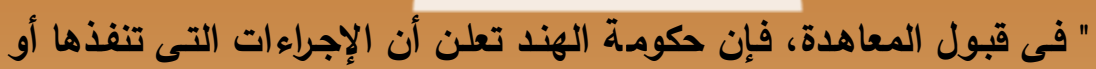

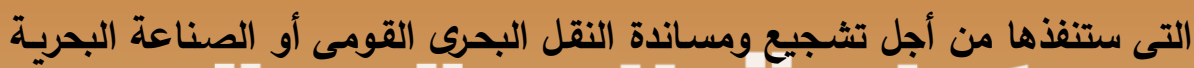

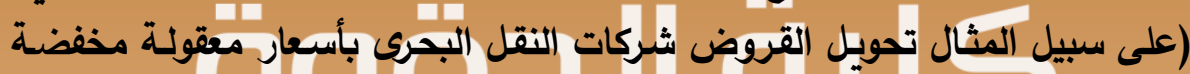

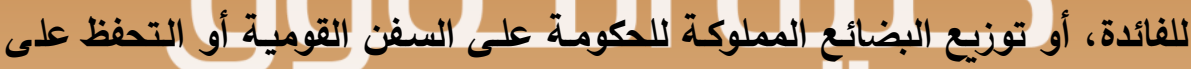

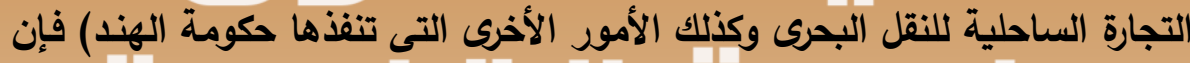

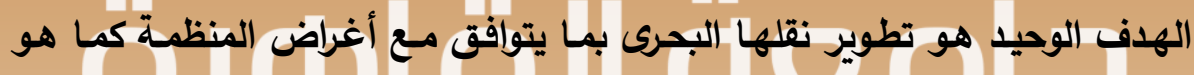
محد في المادة (1)(ب) من المعاهدة". 3

(1) International law commission report, 1999 v. II pt. 2 U.N.Y.B. Int'l L. Commn 105 (1999) para. 2.

(2) International law commission report, 1999 v. II pt. 2 U.N.Y.B. Int'l L. Commn 104 (1999) para 8.

(3) United Nations Treaty Collection. 


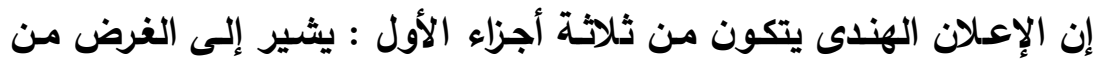

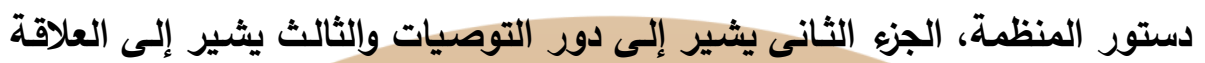

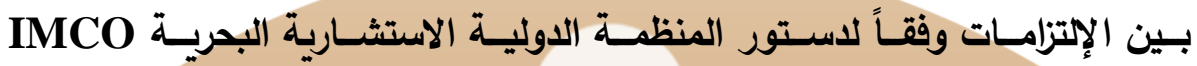
والقوانين الاخلية للهند. 1

وقد أعلنت فرنسا أنها لن تقبل التحفظ الهندى، كما أكدت جمهوريـة ألمانيا

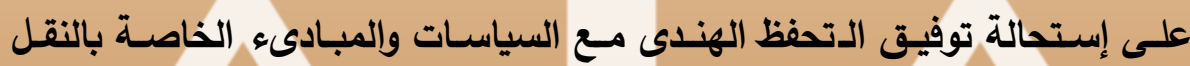
وأغراض المنظمة وإن التحفظ غير متفق مع المادة (1) (ب) من دستورالمنظمة. 2 أما الولايات المتحدة فقد أكدت على إنـاته ليس هناك في الإعلان الهندى مـا

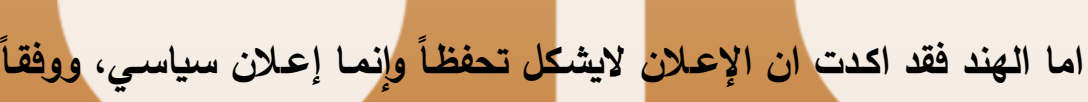

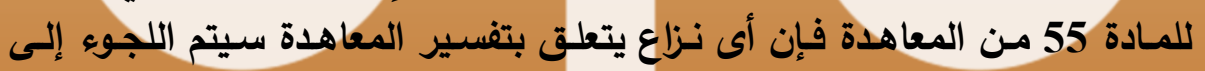

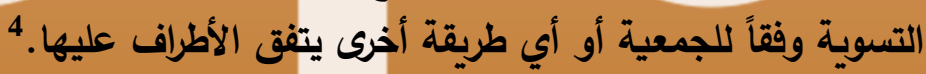

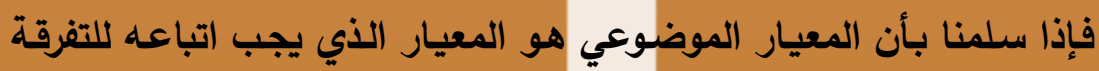

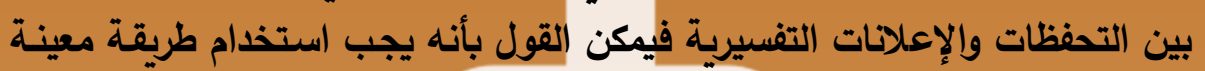

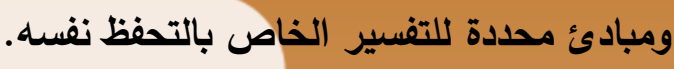

http://treaties.un.org/Pages/ViewDetails.aspx?src=TREATY\&mtdsg_no =XII-1\&chapter=12\&lang=en

(1) United Nations Treaty Collection, http://treaties.un.org/Pages/ViewDetails.aspx?src=TREATY\&mtdsg_no $=X I I-1 \&$ chapter $=12 \&$ lang=en

(2) United Nations Treaty Collection, http://treaties.un.org/Pages/ViewDetails.aspx?src=TREATY\&mtdsg_no =XII-1\&chapter=12\&lang=en

(3) United Nations Treaty Collection, http://treaties.un.org/Pages/ViewDetails.aspx?src=TREATY\&mtdsg_no $=$ XII-1\&chapter $=12 \&$ lang=en

(4) United Nations Treaty Collection, http://treaties.un.org/Pages/ViewDetails.aspx?src=TREATY\&mtdsg_no =XII-1\&chapter=12\&lang=en 
فهذه المبادئ هي التفسير الحرفي للإعلان وبالتالي فعلى الجهة التي تقوم

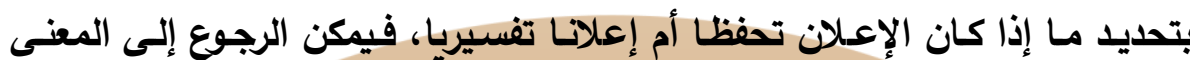

العادي لكلمات المعاهدة.

ويعد التفسير الحرفي لنصوص المعاهدة مـن المسـائل الهامـة عنــ تطبيق

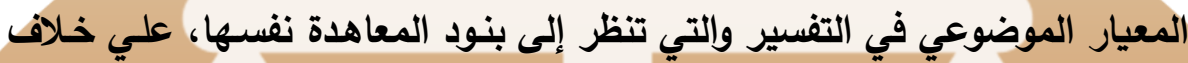
المعيار الثخصي الذي يقوم على النظر الي نية الأطراف. 2

والطربقة الثانية هي نطاق تفسير النص: وذلك بالنظر إلى بنود (لمعاهدة

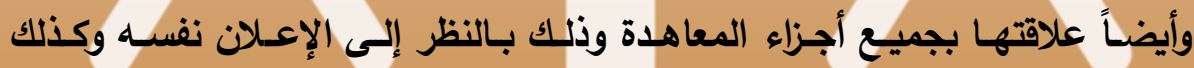
المعاهدة نفسها والنصوص التي ورد الإعلان فيها.

كذلك الغرض والهدف من الاعلان فالنظر إلى الغرض والهدف من الإعلان

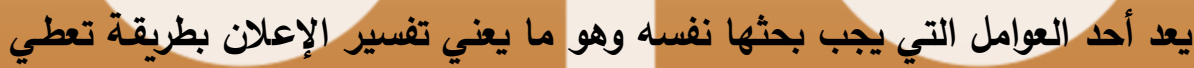

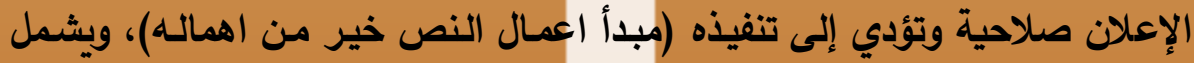
ذلك النظر إلى الأعمال التصضيرية والوسيائل المكملة للمعاهدة. 3

ويمكن القول بان الاخذ بكلا المعيارين سواء الشخصي أو الموضوعي يعد

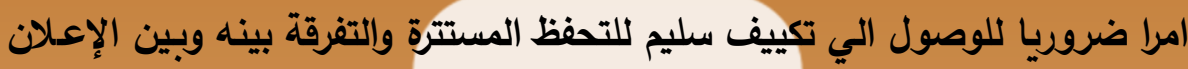

(1) Rebecca J. Cook, Reservations to the Convention on the Elimination of all forms of discrimination against women, 30 Va. J. Int'I L. 660 (198990). (A 1984 advisory opinion of the Inter-American Court of human rights has observed that "this method of interpretation respects the principle of the primacy of the text, that is, the application of objective criteria of interpretation. In the case of human rights treaties, moreover, objective criterial of interpretation that look to the texts themselves are more appropriate than subjective criterial that seek to ascertain only the intent of the Parties").

(2) International law commission report, 1999 v. II pt. 2 U.N.Y.B. Int'l L. Commn 105 (1999); See also Rebecca J. Cook, Reservations to the Convention on the Elimination of all forms of discrimination against women, op. cit., p. 660.

(3) Loc. cit. 
التفسيري.

إن تحليل الإعلان نفسه يقتضي الوصول الي نية الاولية المعلنة الا أنها في الإني

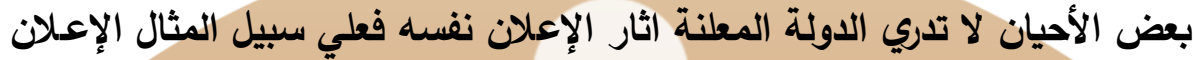

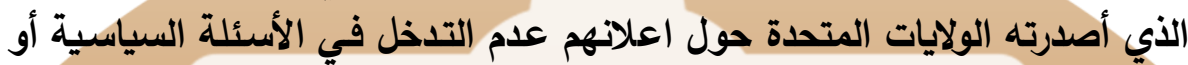
الثئون الداخلية للدولة الأجنبية.

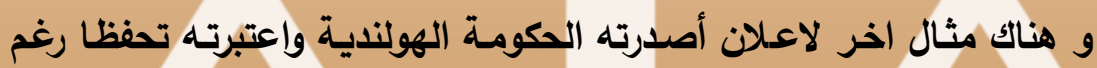

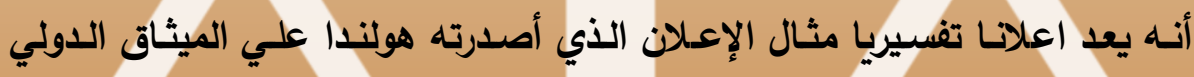

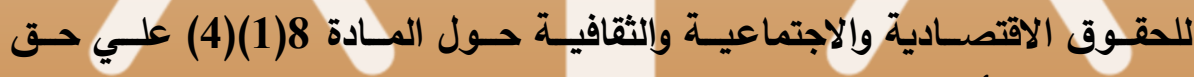
الاضراب. فقد أعلنت هولندا الآتي:

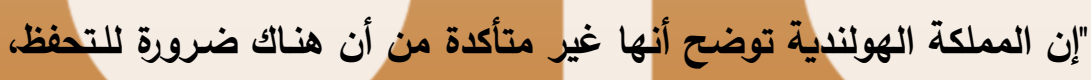

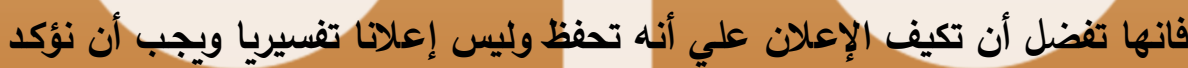
أن الالتزام لا ينطبق علي جزر الآتيل الهولندية.

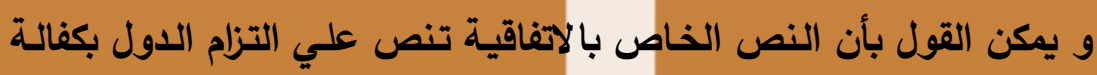

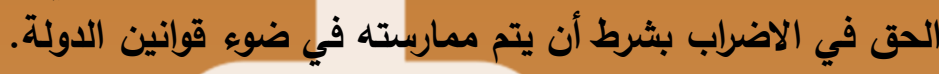

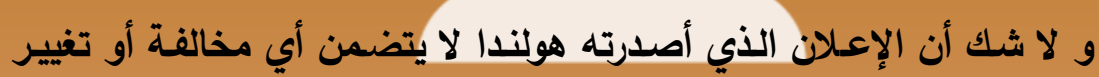

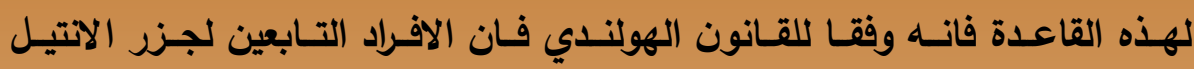

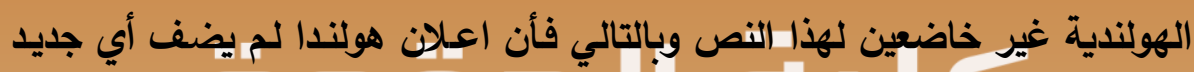

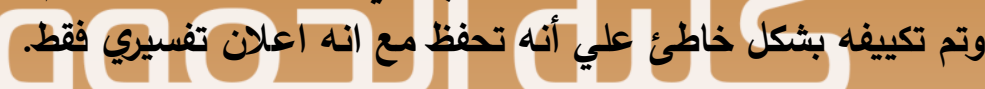
الببمث الثاني

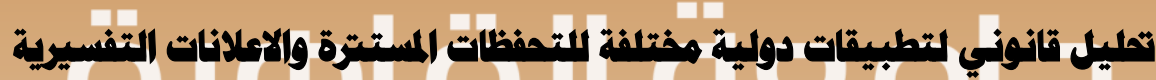

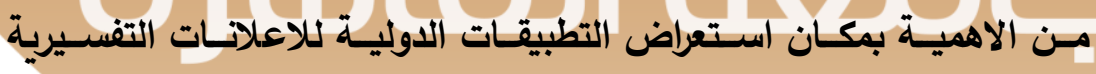

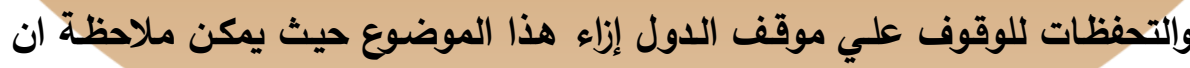

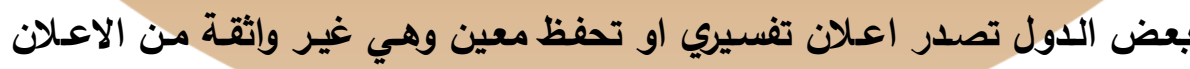

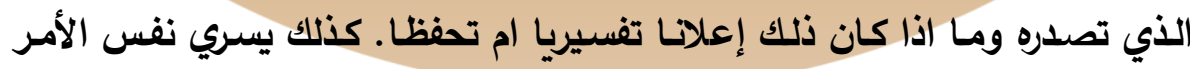

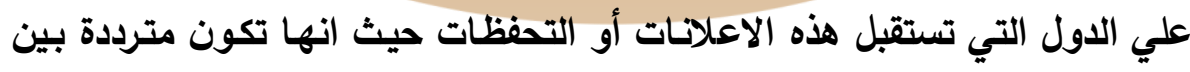


تكييف الاعلان علي انه اعلان تفسيري ام تحفظ وفيما يلي عرض لبعض الامثلة

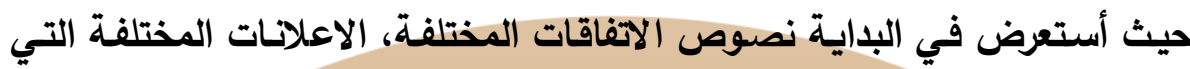

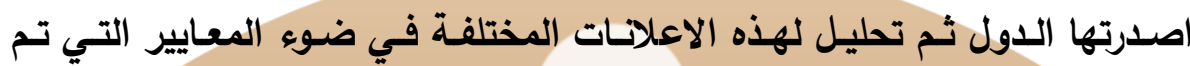
استخلاصها وشرحها في المبحث الأول من هذا الاعل الفصل اتصل. (1) إنفاقية معاقبة ومنع جريمة الإبادة العنصرية (باريس 1948/12/9) تنص المادة (4) علي:

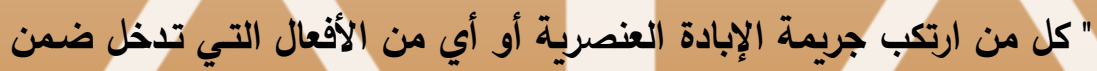

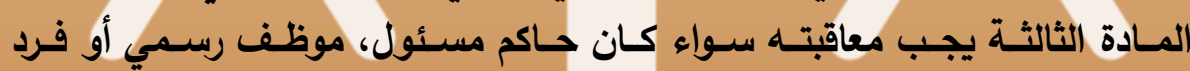
عادي". (1) إعـلان الفلبين (1950/7/7): " بالإثـارة إلي المـادة الرابعة مـن المعاهدة،

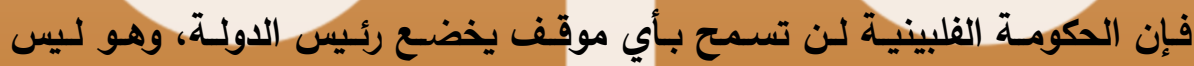
حاكما، لثروط أقل أفضلية من تلك التي تمنح لباقي رؤساء الدول، سواء لـون مسئولين

البرازيل (1952/4/15): "تعتبر التحفظ غير متفق مـع الهدف والغرض من الته

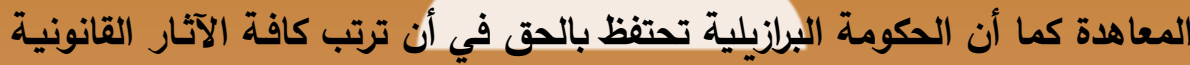

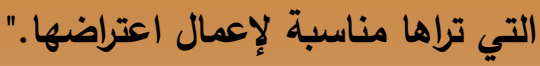

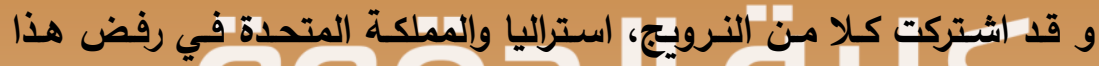

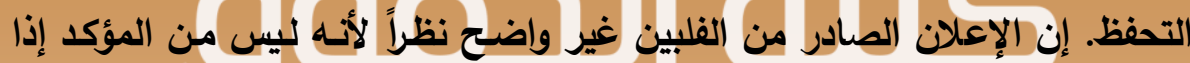
كان رئيس دولة الفلبين لن يخضع لأي بند من بنود الآفاقية.

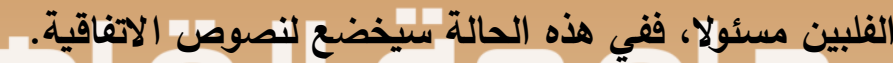

(1) Article 4 of the Convention on the punishment and prevention of the crime of genocide (Paris 9.12. 48). United Nations Treaty Collection, http://treaties.un.org/Pages/ViewDetails.aspx?src=TREATY\&mtdsg_no $=$ IV-1\&chapter $=4$ \&lang $=$ en

(2) United Nations Treaty Collection, http://treaties.un.org/Pages/ViewDetails.aspx?src=TREATY\&mtdsg_no =IV-1\&chapter $=4$ \&lang=en 
و بإعمال قواعد مبدأ حسن النية فيجب مراعاة إحداث تتاغم بين الالتزامـات

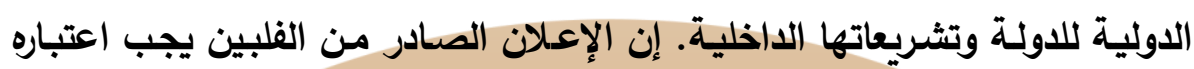

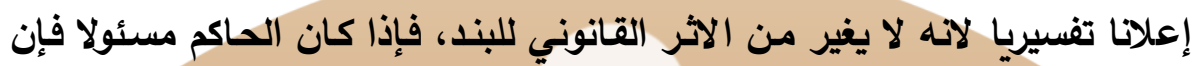

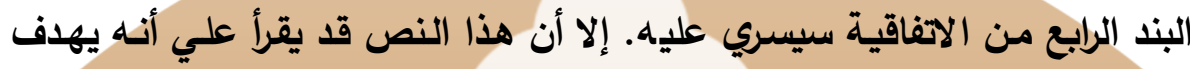

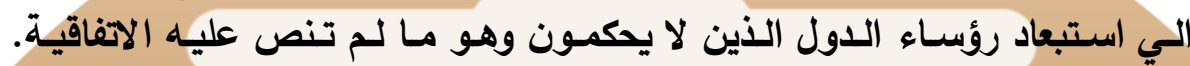

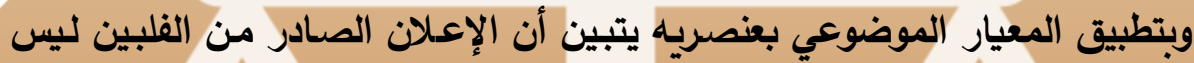

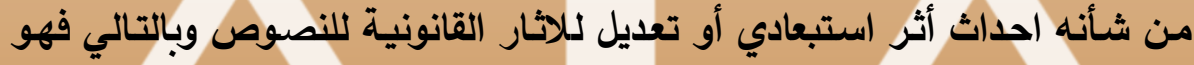
اعلان تفسيري. (2) المعاهدة الدولية لإلغاء كل أشكال التفرقة العنصيةري:

تنص المادة 4 من هذه الإتفاقية علي مـا يلي: "يدين الأطراف الموقعة كل

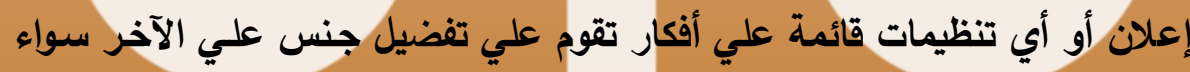

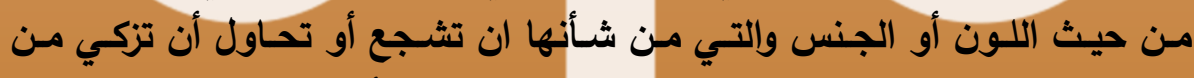

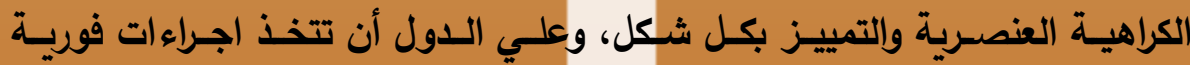

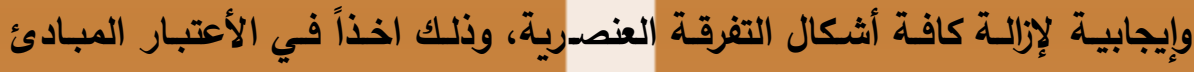

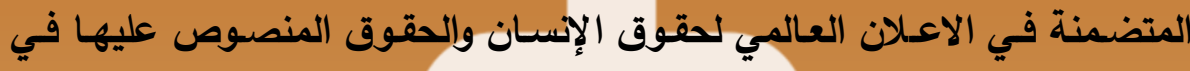

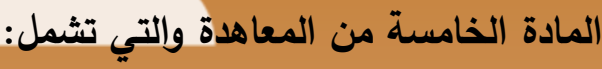
(أ) العقاب علي أي محاولة لتسريب اي أفكار قائمـة علي التمييز العنصري

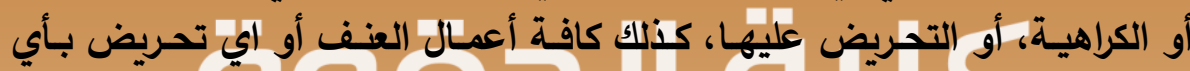
شكل من الاثكال ضد أي مجموعة أو جنس من لون الون معين أو تقديم اي مسـاعدة

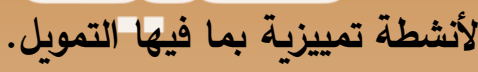
(ب) تحريم هذه التظظيمات وكذلك كافة أنثطة الإعلاتات التي تحرض علي فئي الكراهية العنصرية والتمييز العنصري وكذلك تجريم المشاركة في هذه التنظيمات.

(ج) أي سلطات عامة او محلية تقوم بتثجيع أو زيادة التمييز العنصري.)

(1)Article 4 of the International Convention on the Elimination of All Forms of Racial Discrimination (Article 4). United Nations Treaty Collection, 
الإعـلان الصـادر من أستراليا (1975/9/30): "تعلن استراليا أنها لن تقوم

بتجريم كافة الأعمال المنصوص عليها في المـادة (4) (أ)، نظرا لأن جميع هذه الأه

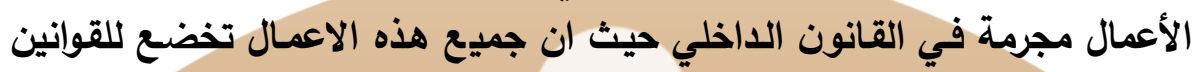

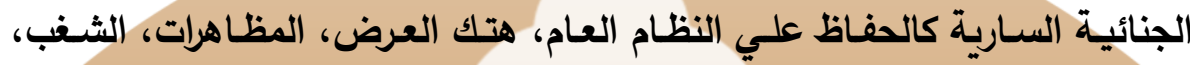

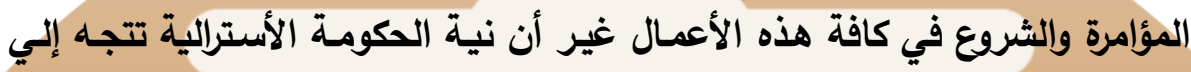

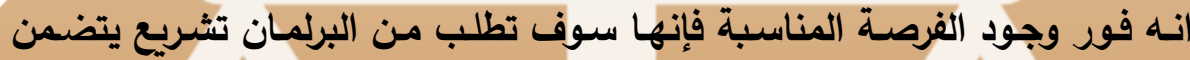

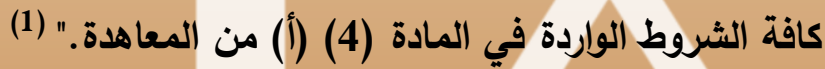
إن الاعـلان الاسـترالي يعـد اعلانـا تفسـيريا نظـرا لاتـهـه لا يغيـر مـن الاخـر

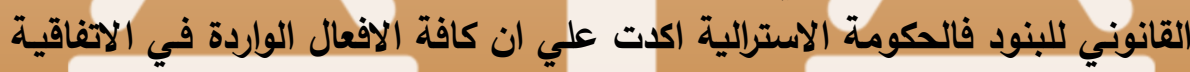

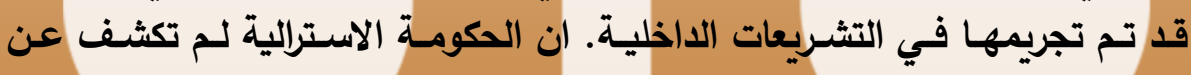

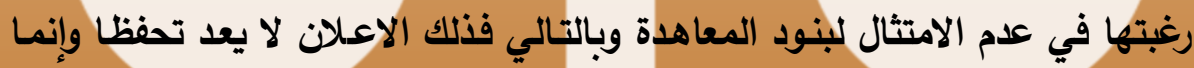
اعلانا تفسيزيا.

النمسا (1972/5/9): "تشير المادة الرابعة من الإتفاقية إلي كافة الاجراءات

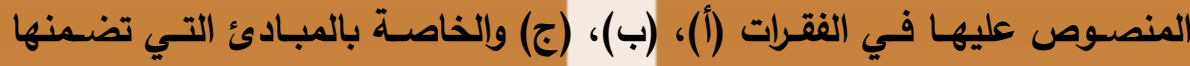

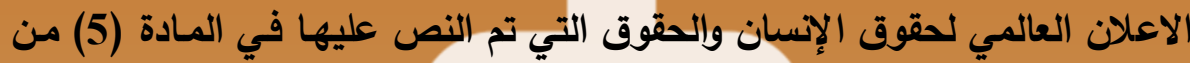

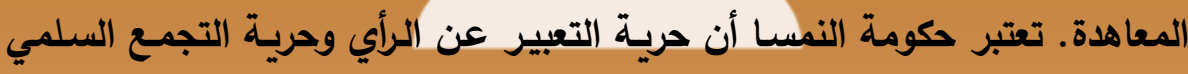

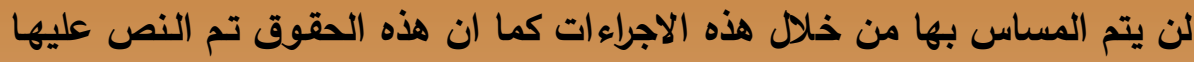

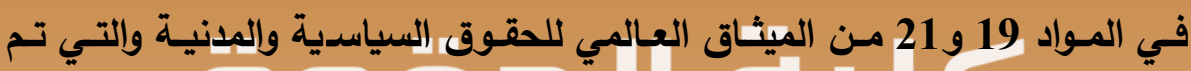

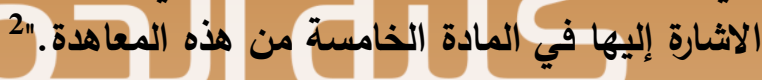
(الباهامز ) (1975/8/5):" تعبر جزر الباهامز عن فهمها الخاص بالمـادة

http://treaties.un.org/Pages/ViewDetails.aspx?src=TREATY\&mtdsg no =IV-2\&chapter $=4$ \&lang=en

(1) United Nations Treaty Collection, http://treaties.un.org/Pages/ViewDetails.aspx?src=TREATY\&mtdsg_no $=I V-2 \&$ chapter $=4 \&$ lang $=$ en\#EndDec

(2) United Nations Treaty Collection, http://treaties.un.org/Pages/ViewDetails.aspx?src=TREATY\&mtdsg_no $=$ IV-2\&chapter $=4 \&$ lang=en\#EndDec 
الرابعة من المعاهدة الدولية لإلغاء كافة صور التمييز العنصري، فهي تفسر المادة

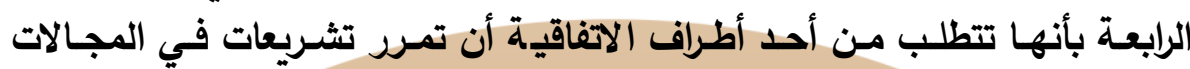

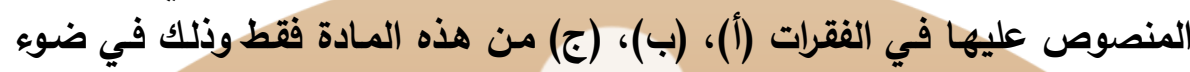

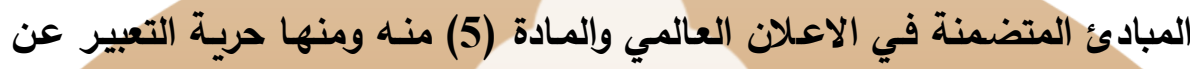

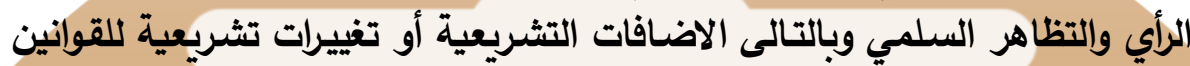

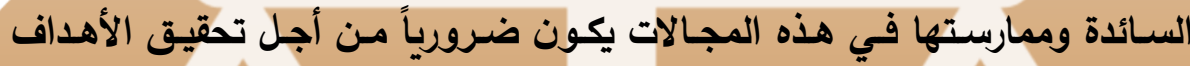

المدادة في المادة الثرابعة".

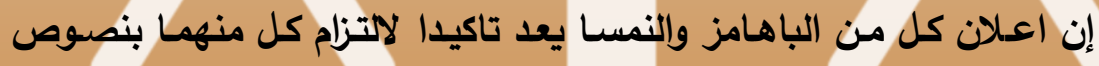

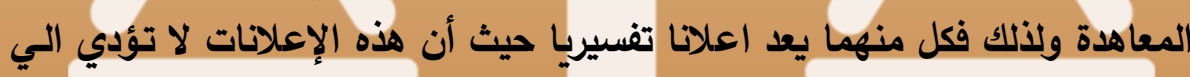

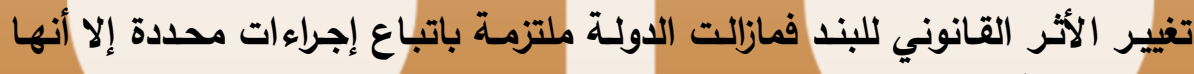

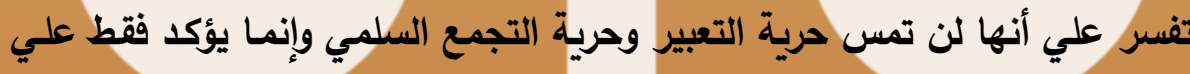

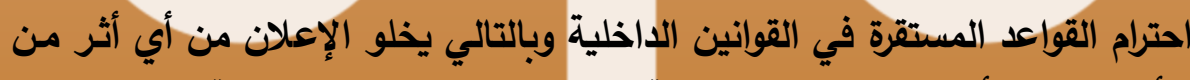
شأنه استبعاد أو تعديل الآثار القانونية للنصوص الوانئ الواردة في الآفاقية.

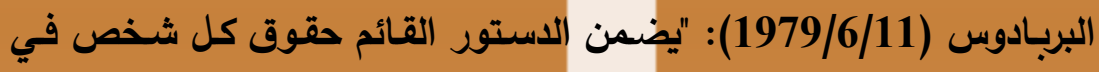

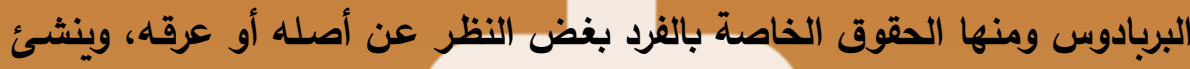

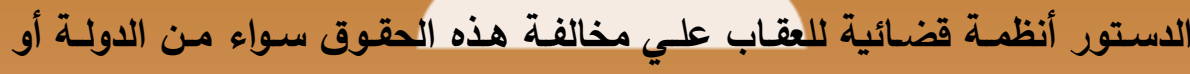

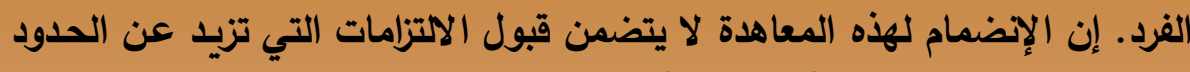

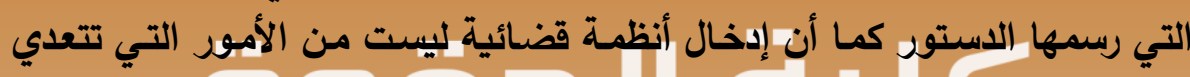

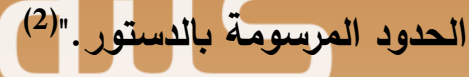

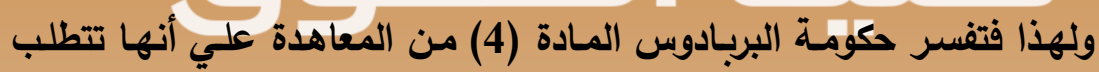

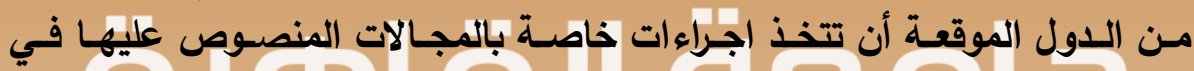

(1) United Nations

Treaty

Collection, http://treaties.un.org/Pages/ViewDetails.aspx?src=TREATY\&mtdsg_no $=\mathrm{IV}-2$ \&chapter $=4 \&$ lang $=$ en\#EndDec

(2) United Natoins Treaty Collection, http://treaties.un.org/Pages/ViewDetails.aspx?src=TREATY\&mtdsg_no =IV-2\&chapter=4\&lang=en\#EndDec 
الفقرات (أ)، (ب)، (ج) من هذه المادة فقط عندما تكون هناك حاجة لذلك".

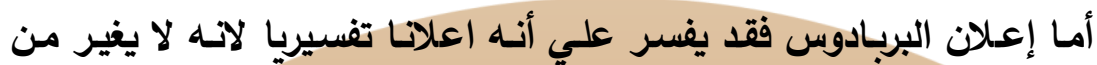

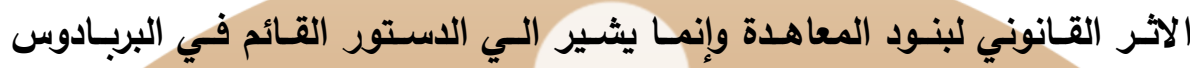

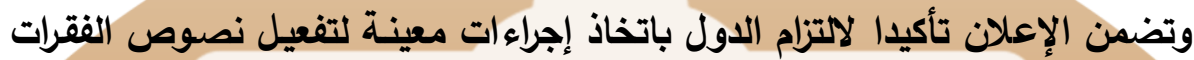

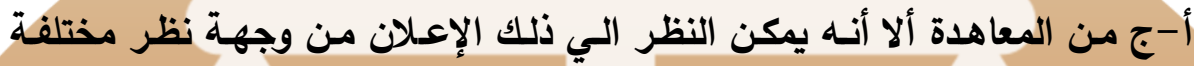

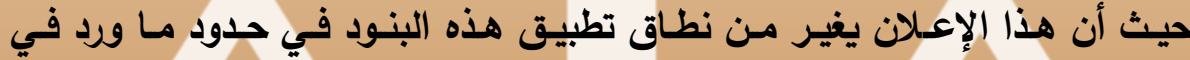

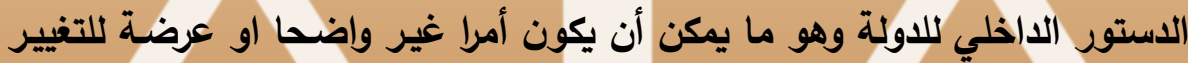

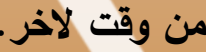

بلجيكا (1975/8/7): "من أجل تنفيذ متطلبات المـادة الرابعة من الاعلان

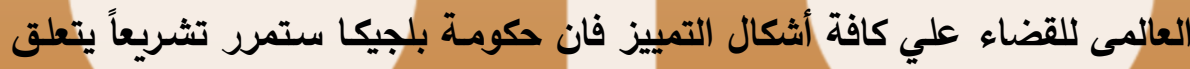

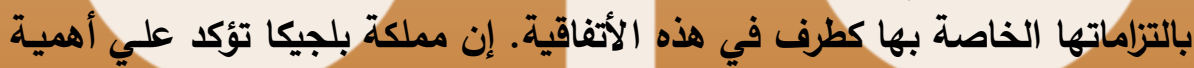

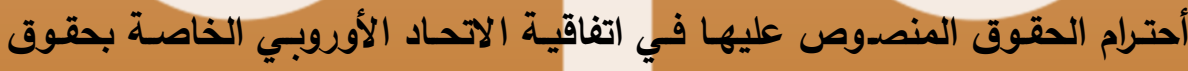

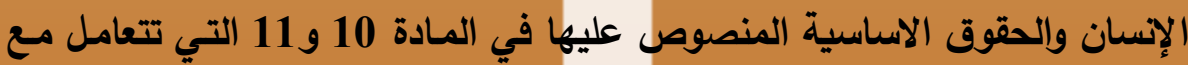

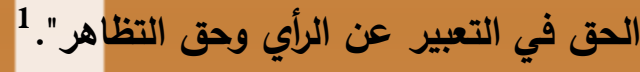
فرنسـا (1971/7/28): "تفسر فرنسـا الاثــارة إلي مبادئ الإعـلان العـالمي لحقوق الإنسان والحقوق الواردة في المادة (5) من المعاهدة علي أنها تعفي الدول

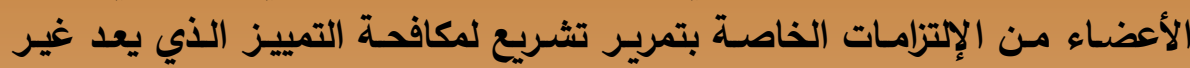

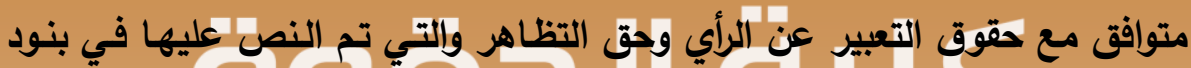

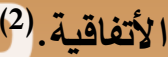

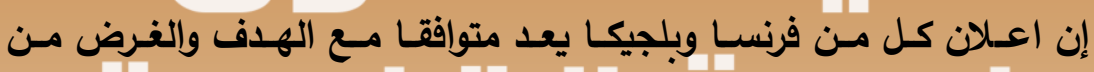

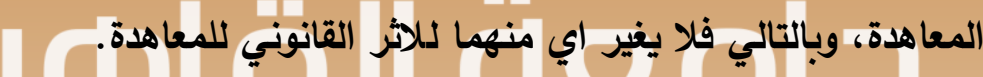
(3)

(1) United Nations Treaty Collection, http://treaties.un.org/Pages/ViewDetails.aspx?src=TREATY\&mtdsg_no $=$ IV-2\&chapter $=4 \&$ lang=en\#EndDec

(2) United Nations Treaty Collection, http://treaties.un.org/Pages/ViewDetails.aspx?src=TREATY\&mtdsg_no $=I V-2 \&$ chapter $=4 \&$ lang $=$ en $\#$ EndDec 
إيطاليا (1976/1/6): أعلنت إيطاليا أن الفقرات (أ) و و(ب) يجب تفسيرها

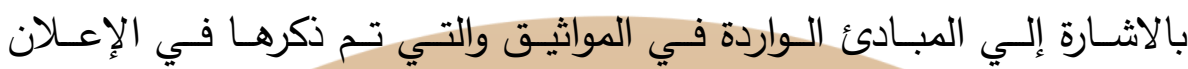
الأسترالي.

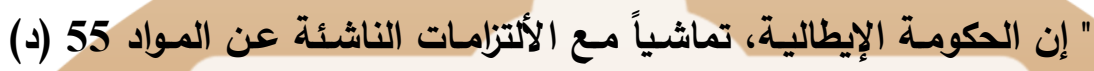

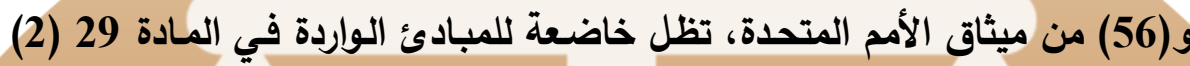

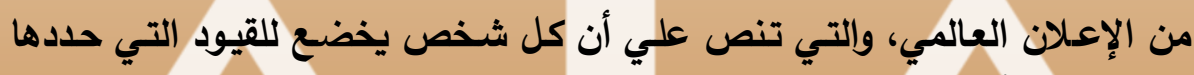

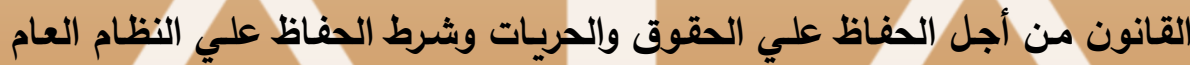

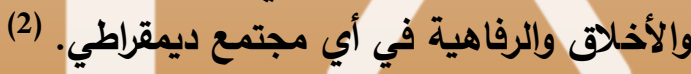

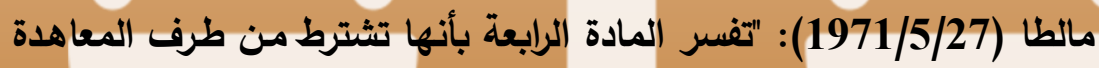

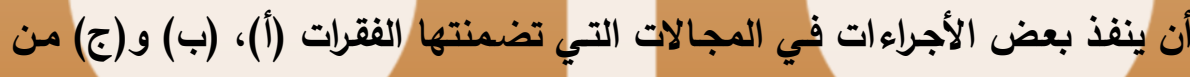

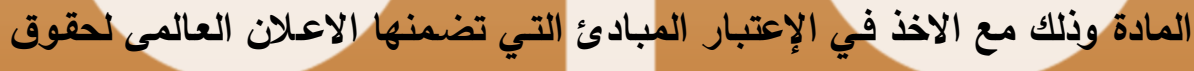

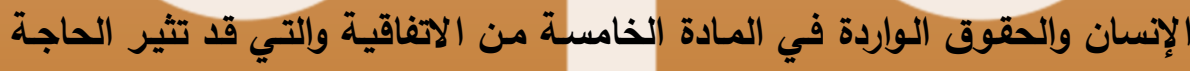

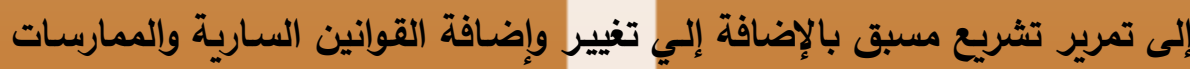
التي تضع نهاية للتمييز العنصري.

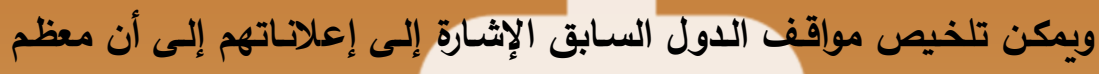

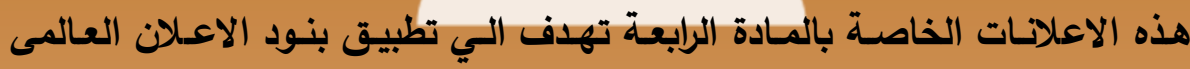

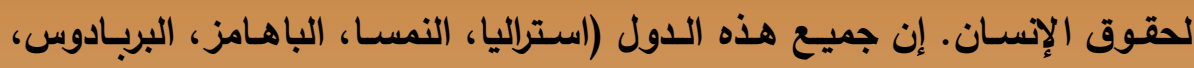

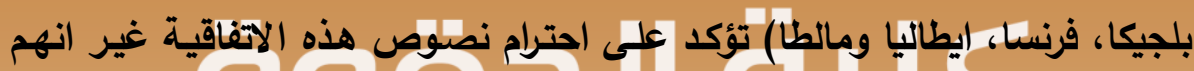
قاموا بتوضيح الهمية تمرير تثريعات داخيات دوكلية لتنفيذ كافة بنود المعاهدة.

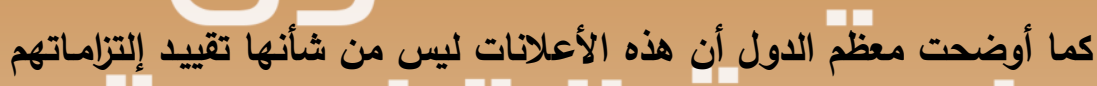

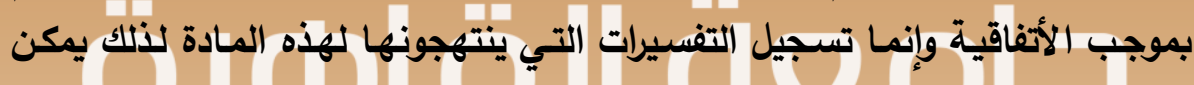

(1) United Nations

Treaty Collection, http://treaties.un.org/Pages/ViewDetails.aspx?src=TREATY\&mtdsg_no $=\mathrm{IV}-2$ \&chapter $=4 \&$ lang $=$ en\#EndDec

(2) United Nations Treaty Collection, http://treaties.un.org/Pages/ViewDetails.aspx?src=TREATY\&mtdsg_no $=I V-2 \&$ chapter $=4 \&$ lang=en\#EndDec 
القول بأن الغالبية العظمي من هذه الدول تعتبر هذه الإعلانـات بمثابة إعلانـات

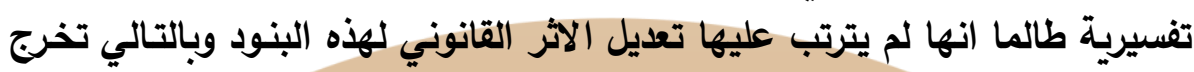

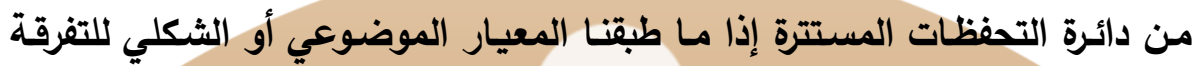
بين الإعلانات التفسيرية والتحفظات المستترة.

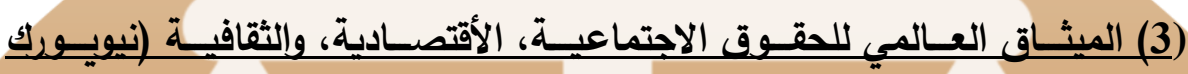
$\underline{(1966 / 12 / 16}$ تنص المـادة (1) من هذا الميثاق علي: "تتمتع كل الأمـ بالحق في تقرير

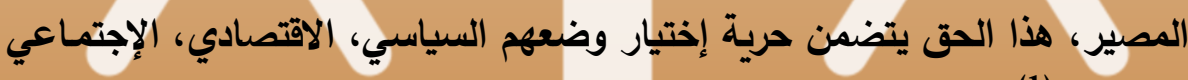
والثقافي."(1) (1)

وقد أعلنت الهند (1979/4/10) الاتي: " تعلن أن تفسير كلمـة " حق تقرير

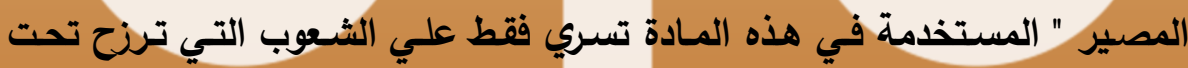
الإحتلال الأجنبي ولا تنطبق علي الدول أو الأمم المستقلة".

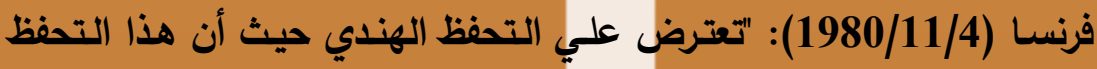

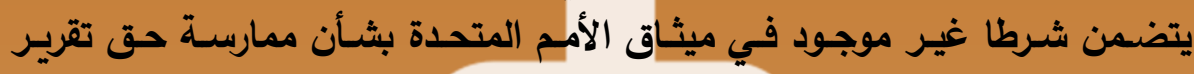

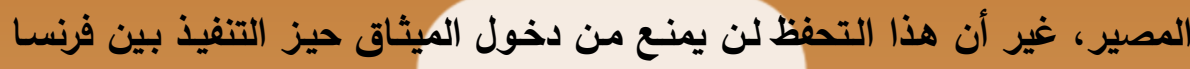
واللهند"

ألمانيا (1980/8/15): "إن حق تقرير المصير كمـا يتضــنه ميثـاق الأمـم

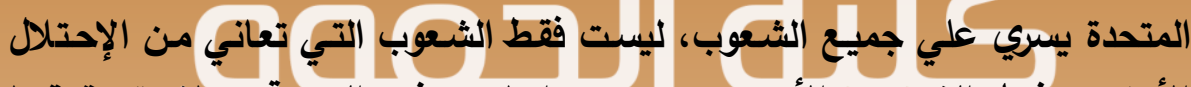

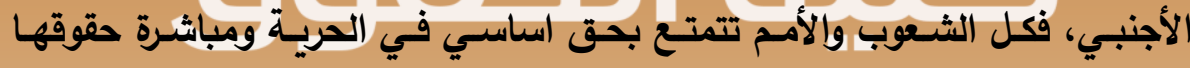

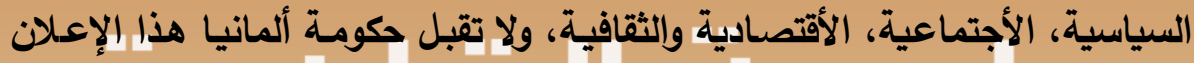

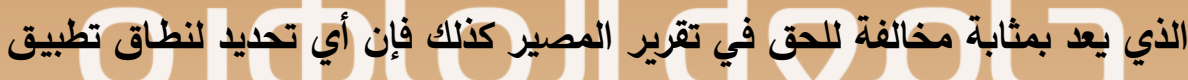

(1) Article 1 of the International Covenant on Economic, Social and Cultural rights (New York 16.12.1966).

(2) United Nations Treaty Collection, http://treaties.un.org/Pages/ViewDetails.aspx?src=TREATY\&mtdsg_no =IV-3\&chapter $=4$ \&lang $=$ en 
الميثاق علي جميع الأمم يتعارض مع الهدف واللغرض من هذه المواثيق."(1) إن رد فعل كل مـن فرنسـا والمانيـا يعــ صـائبا نظرا لان الاعـلان الهندي

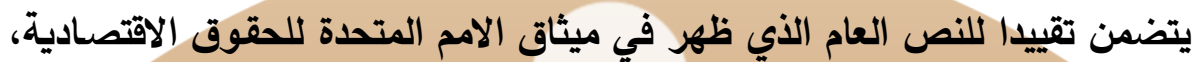

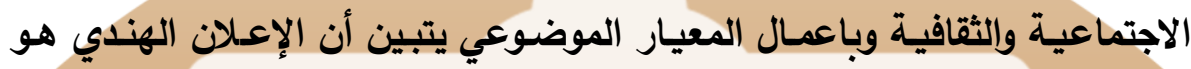

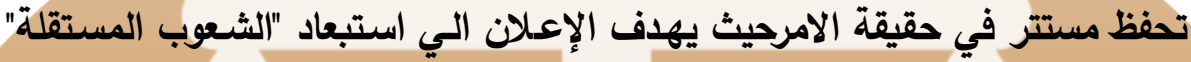

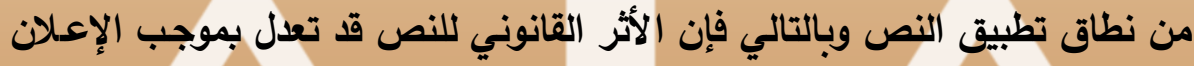
هولندا (1981/11/12): "تعترض علي الاعلان الهندي حيث أن الحق في

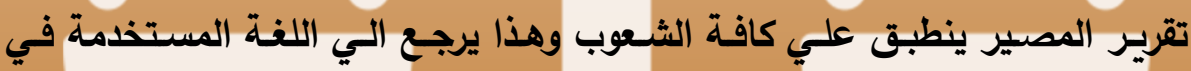

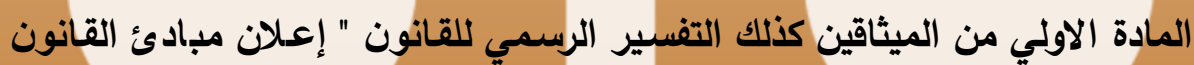

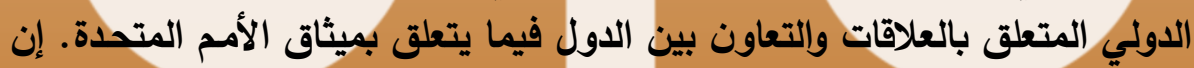

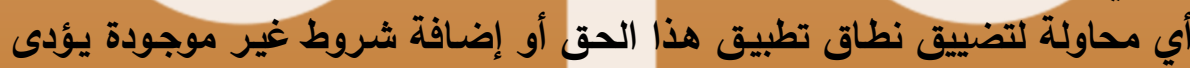
إلي الإخلال بحق تقرير المصير وبضعف من صفته العالمية. 2

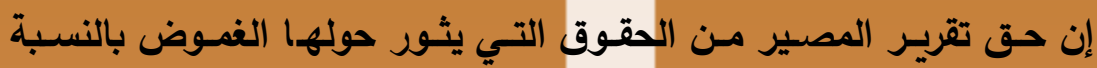

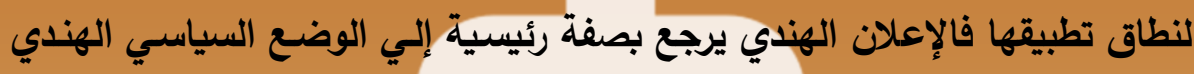

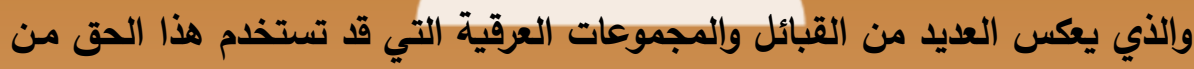

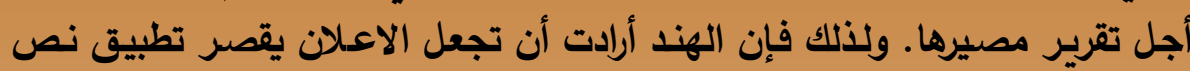

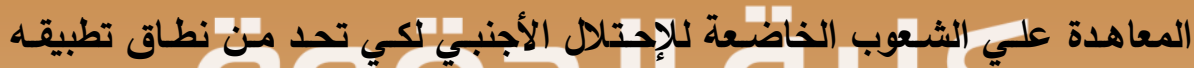
كمصطلح قانوني علي القبائل الموجودة داخل الهند.

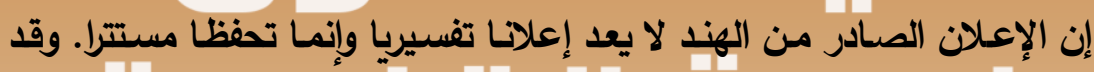

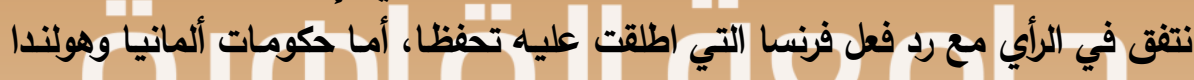

(1) United Nations Treaty Collection, http://treaties.un.org/Pages/ViewDetails.aspx?src=TREATY\&mtdsg_no $=$ IV-3\&chapter $=4$ \&lang $=$ en

(2)http://treaties.un.org/Pages/ViewDetails.aspx?src=TREATY \&mtdsg no $=\mathrm{IV}-3 \&$ chapter $=4$ \&lang=en 


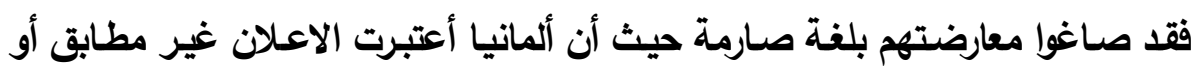
متفق مـع هدف وغرض الميثاق.(1) فالاعلان الهندي هو في حقيقته تحفظا مستترا

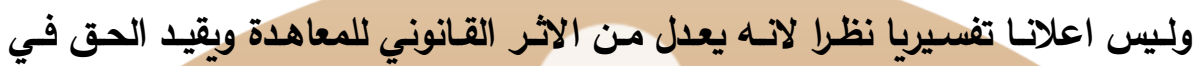

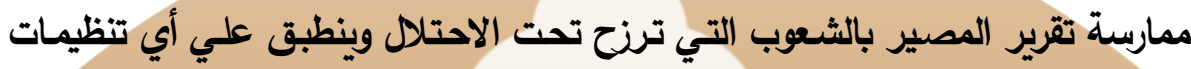

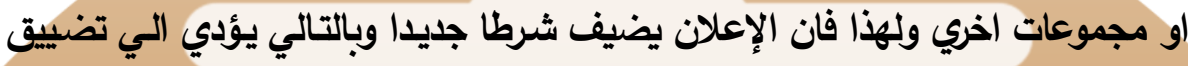
نطاق تطبيق المادة ليخرج من نطاقه الأمم المستقلة وإلدول المستقلة. تنص المادة (8) من نفس الميثاق علي:

1- " إن الدول الموقعة علي المعاهدة السارية عليها أن تلتزم بالتأكيد علي: (أ) حق كل فرد في أن يشكل تجمـع تجاري أو المشـاركة في تجمـع تجاري من

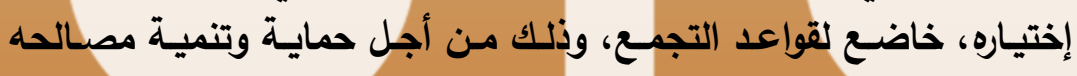
الاجتماعية والإقتصادية.

ولا يمكن تقييد هذا الحق بأي شكل إلا فيما يتعلق بالقيود التي يفرضهها

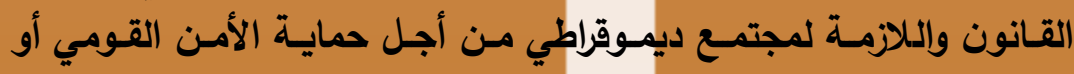
النظام العام أو حماية حقوق وحريات الآخرين. (ب)حق التجمعات التجارية في تكوين اتحادات قومية وحق الأخير في تشكيل

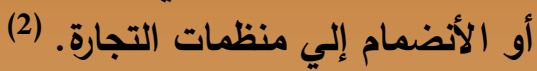

(ج) حق التجمع التجاري في أداء وظائفه بحربـة ودون قيود غير التي يقرهـا

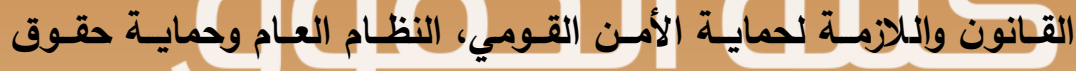
وحريات الأفراد في مجتمع ديموقراطي. (د) حق التظاهر إذا كان ممارسته وفقاً لقوانين الدول المختلفة. (1) فيمرئ

(1) Nations Treaty Collection, http://treaties.un.org/Pages/ViewDetails.aspx?src=TREATY\&mtdsg_no $=\mathrm{IV}-3 \&$ chapter $=4 \&$ lang $=\mathrm{en}$

(2) Art. 8 of. of the International Covenant on Economic, Social and Cultural rights (New york 16.12.1966) 


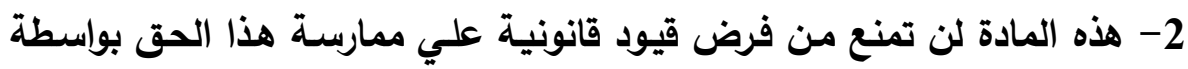
أعضاء القوات المسلحة أو الثرطة أو إدارة الدولة.

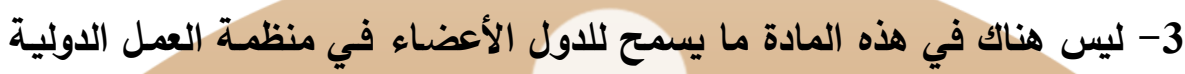

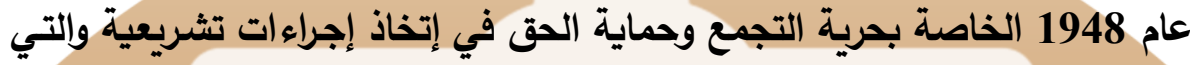
تخل، أو تطبق القانون بثكل قد يخل بالضمانات المقررة بهذه المعاهدة.

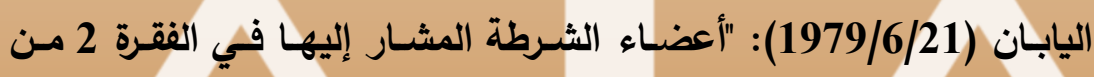

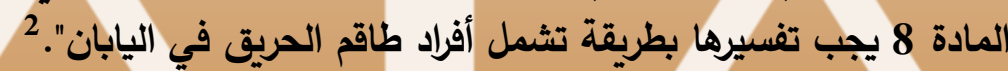

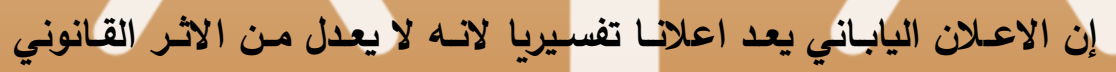

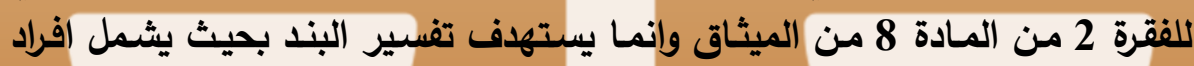

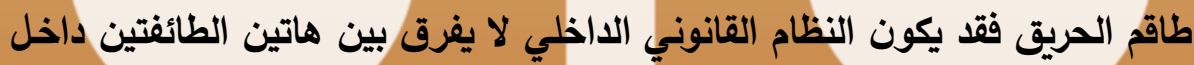
التنظيم اللاخلي للاوولة اليابانية.

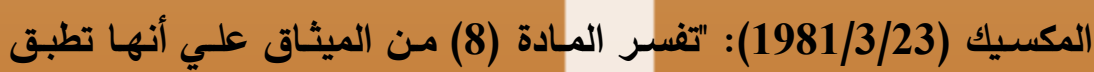

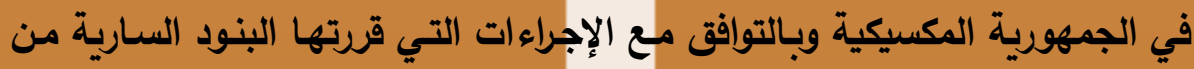
الدستور السياسى للولايات المكسيكية المتحدة وكافة التشريعات السارية التائية الآخري".

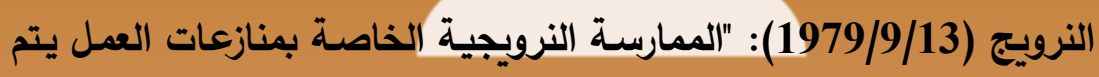

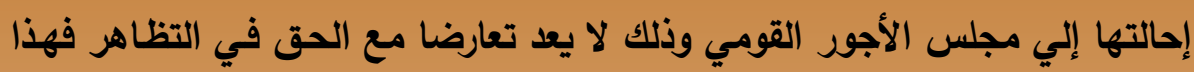
الحق يتم ممارسته بثكل كامل في النرويج".

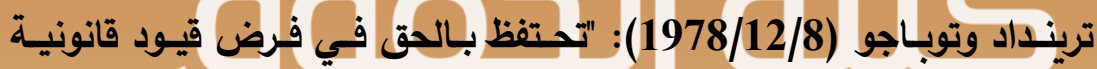
ومناسبة علي استخام الحقوق المشار اليها بواسطة الأفراد المسئولين عن تقديم

(1) United Nations

http://treaties.un.org/Pages/ViewDetails.aspx?src=TREATY\&mtdsg_no $=$ IV $-3 \&$ chapter $=4 \&$ lang $=$ en

(2) United Nations Treaty Collection, http://treaties.un.org/Pages/ViewDetails.aspx?src=TREATY\&mtdsg_no $=\mathrm{IV}-3 \&$ chapter $=4 \&$ lang $=\mathrm{en}$

(3)http://treaties.un.org/Pages/ViewDetails.aspx?src=TREATY\&mtdsg_no $=$ IV-3\&chapter $=4$ \&lang $=$ en 
الخدمات الضرورية بموجب قانون العلاقات الصناعية أو أي قانون آخر والمتوافق

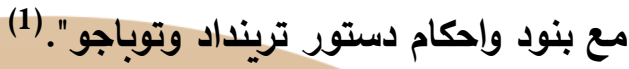
ان معظم هذه الاعلانـات تعد اعلاتـات تفسيرية فعلي سبيل المثال قامـت

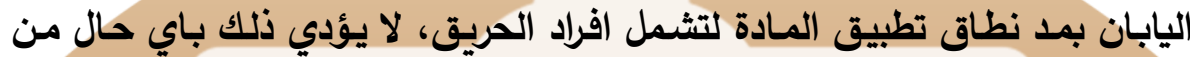

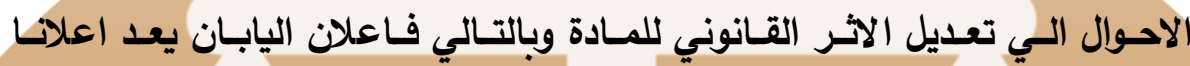

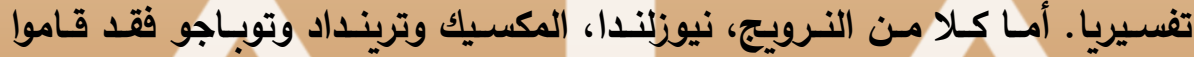

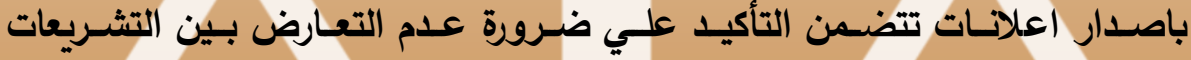
الداخلية والاتفاقيات الدولية. لم يتضمن أيا من هذه اعلات الاعلانات أي تغيير أو تعديل

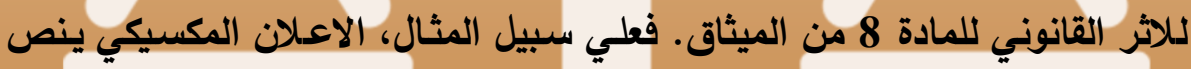

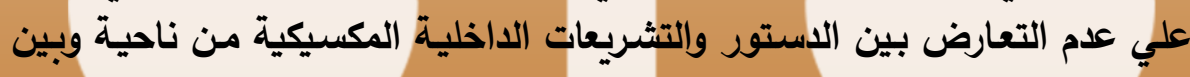

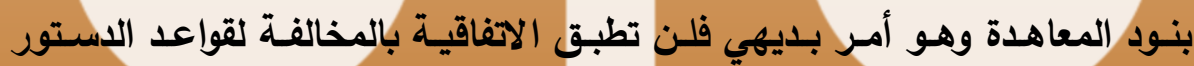

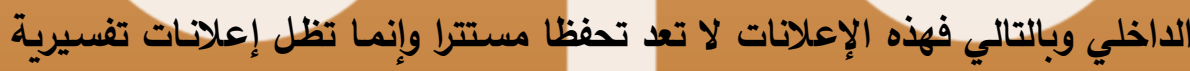

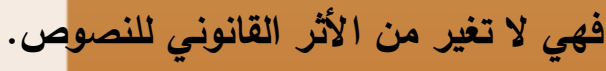
(4) الإيثاق العلامي لامقوق المننية والسياسية:

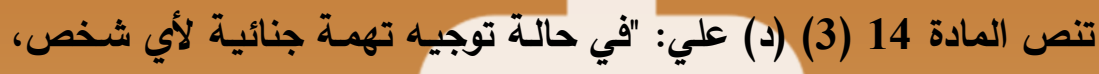

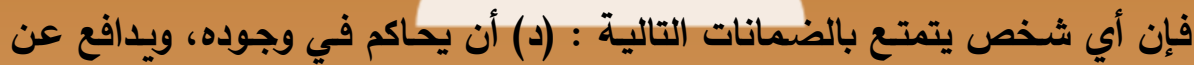

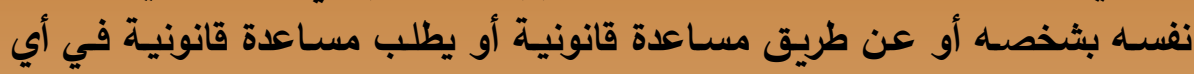

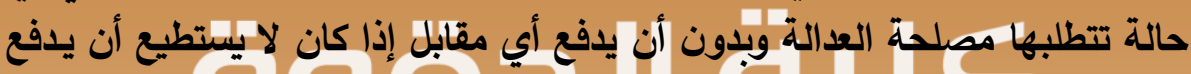

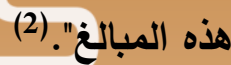
: الاعلانات

(1) United
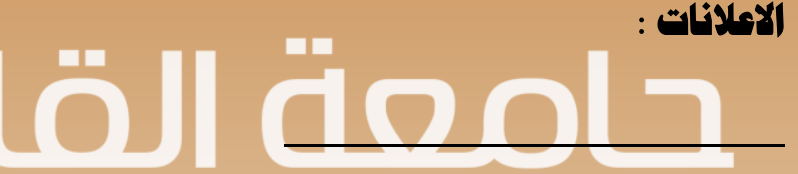

http://treaties.un.org/Pages/ViewDetails.aspx?src=TREATY\&mtdsg_no $=$ IV-3\&chapter $=4$ \&lang=en

(2)Article 14 (3) of International Covenant on Civil and Political rights, United Nations Treaty Series, http://treaties.un.org/Pages/ViewDetails.aspx?src=TREATY\&mtdsg_no $=\mathrm{IV}-\mathbf{4} \&$ chapter $=4 \&$ lang=en 
النمسـا (1978/9/10): "إن الفقـرة الثالثـة مـن المـادة 14 لا تتعـارض مـع

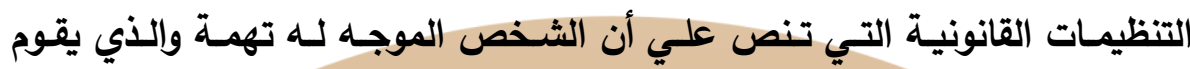

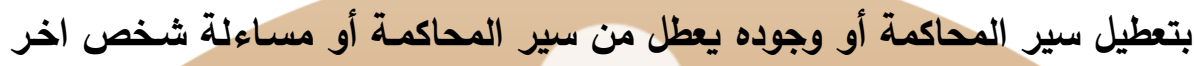

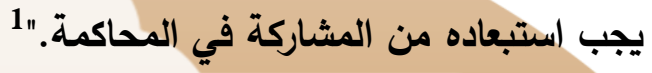

إن الاعلان النمساوي يعد تحفظا مستترا نظرا لانـه يعدل من الآر القانوني

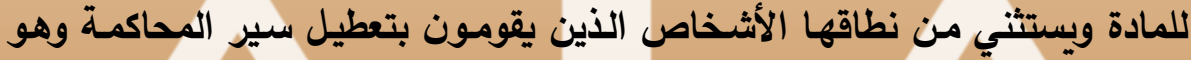

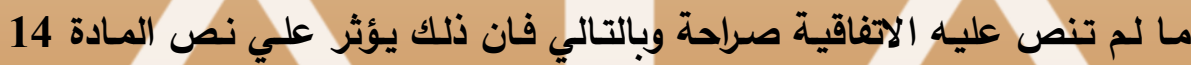
وبضيق من نطاقها.

ألمانيا (1973/12/17):"إن المـادة 14 مـن الميثاق تطبق بطريقـة تســح

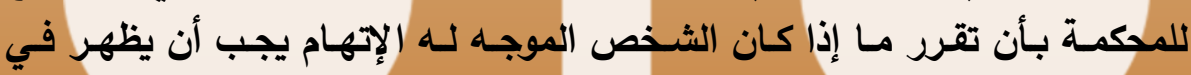
محكمة الموضوع ام لا".

يثور بعض الثك حول الاعلان الالماني ومـا اذا كان يعد اعلانـا تفسيريا ام

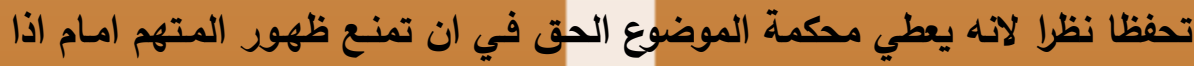

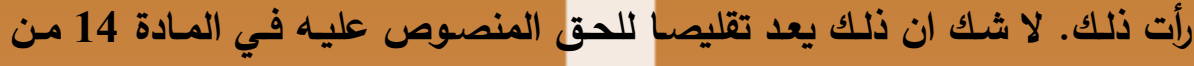

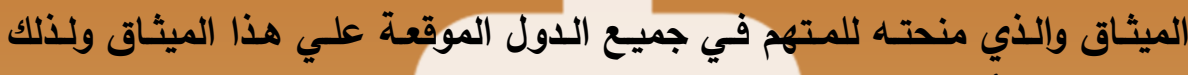
يمكن القول بأن ذلك يعد تحفظا مستترا.

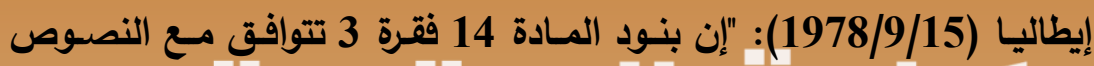

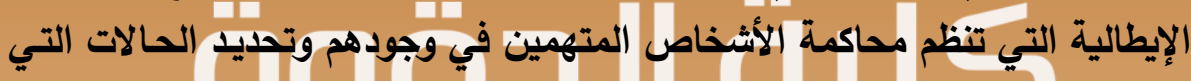
يكون للمتهم الحق في تقديم دفاعه أو الإستعانة بالمساعدة القانونية. 3

(1) United Nations http://treaties.un.org/Pages/ViewDetails.aspx?src=TREATY\&mtdsg_no $=I V-4 \&$ chapter $=4 \&$ lang $=$ en

(2)http://treaties.un.org/Pages/ViewDetails.aspx?src=TREATY\&mtdsg_no $=I V-4 \& c h a p t e r=4 \&$ lang=en United Nations Treaty Collection,

(3) Article 14 (3) of international convention on civil and political righs. United Nations Treaty Collection, http://treaties.un.org/Pages/ViewDetails.aspx?src=TREATY\&mtdsg_no =IV-4\&chapter $=4$ \&lang $=$ en 
إن الاعـلان الايطالي يعد اعلانـا تفسيريا نظرا لاتهله يتضـن تفسيرا مؤكـا

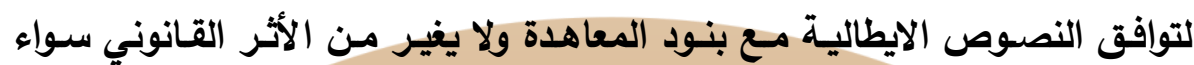

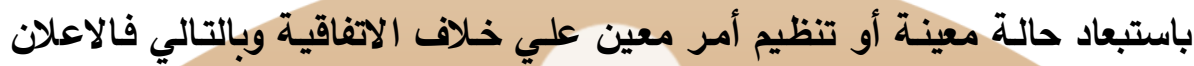

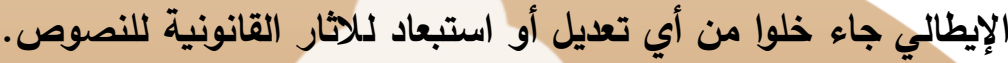
فنزويلا (1978/5/10): "تنص المادة 60 فقرة 5 من دستور فنزويلا علي:

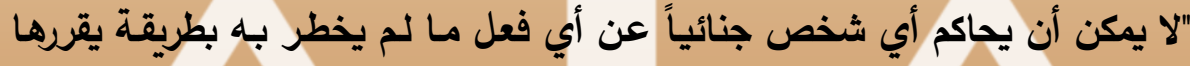
القانون أمـا الأشخاص الذين يرتكبون أفعالاً ضـا الأمـة فيمكن محاكمتهم غيابياً ووفقاً للضمانات المقررة وفقاً للقانون."

إن فنزويلا تطرح هذا التحفظ لأن المـادة 14 ( الفقرة 3 / د ) من الميثاق لا

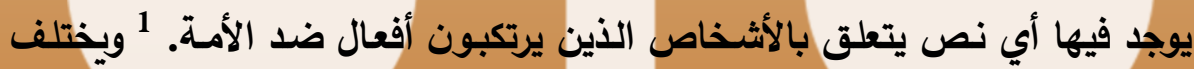

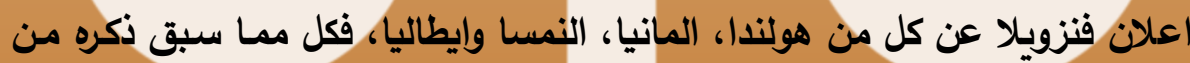

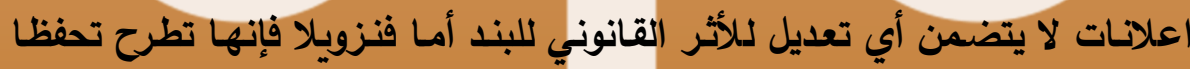

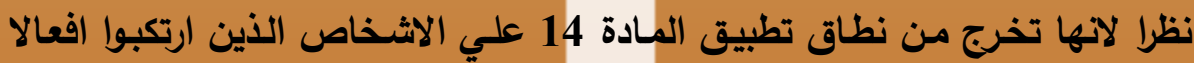

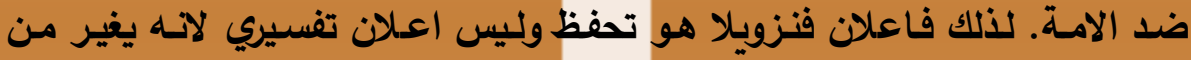

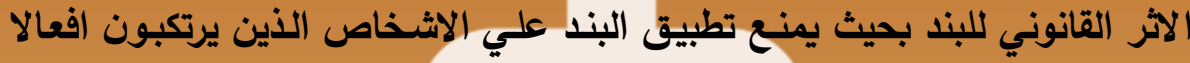

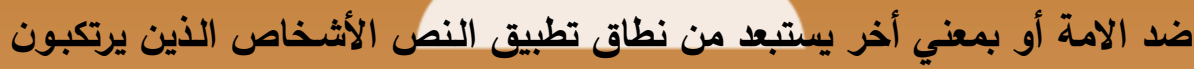

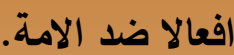

فرنسا (1980/11/4): "إن حكومـة فرنسـا تدخل تحفظاً علي المواد 9 و14

بطريقة لا تؤثر علي تنفيذ هذه القواعد المتعلقة بالاجراء التأديبي للجيوشيل.

لوكسـبرج (1983/8/18): "إن حكومـة لوكسـمبورج تعلـن أن المـادة 14 /

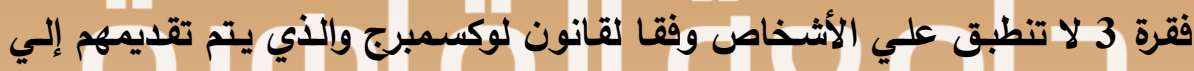

(1) United

Nations

Treaty

Collection, http://treaties.un.org/Pages/ViewDetails.aspx?src=TREATY\&mtdsg_no $=\mathrm{IV}-4 \&$ chapter $=4 \&$ lang $=\mathrm{en}$

(2) United Nations Treaty Collection, http://treaties.un.org/Pages/ViewDetails.aspx?src=TREATY\&mtdsg_no $=\mathrm{IV}-\mathbf{4} \&$ chapter $=4 \&$ lang=en 
تنص المادة (14 ) (3) (د) علي حقوق أساسية للمتهم وهي ان يحاكم في

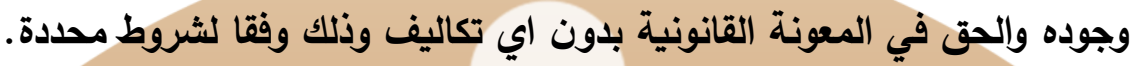

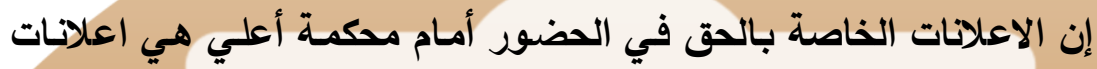

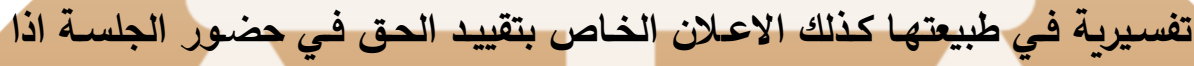

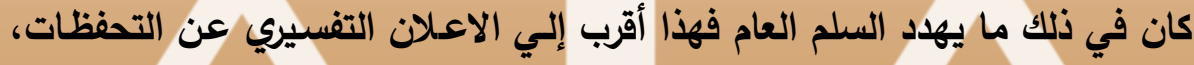

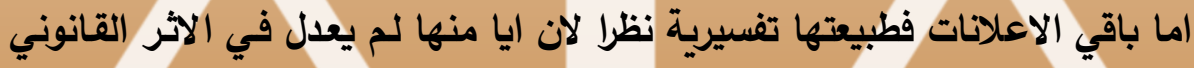

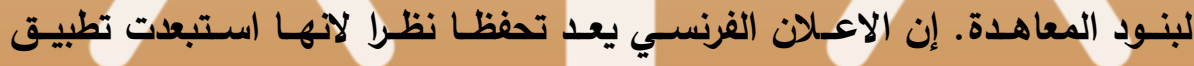

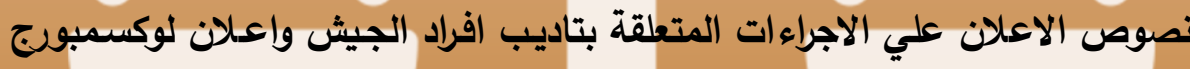

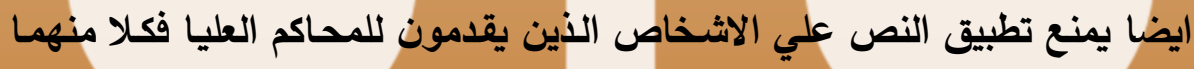
يشكل تحفظا مستترا.

(5) المعاهدة المتعاقة بمالة اللاجنيين (جنيف 1951/7/28) تنص المادة 17 من المعاهدة الخاصة باللاجئين علي الاتي:

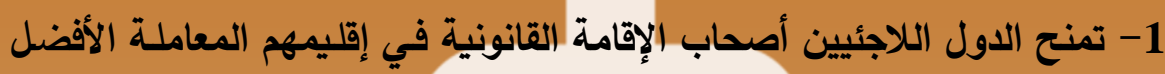

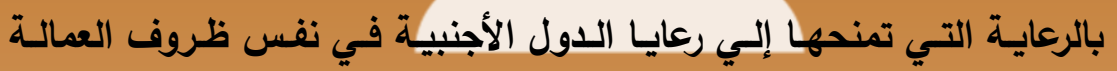

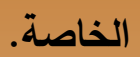

2- وعلي أيسة حال، فإن الأجراءات الوقائية التي تتبعها الدول من أجل حماية

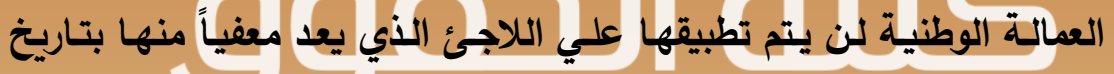
نفاذ المعاهدة أو الذي تسري عليه أحد الشروط الآية: 1 قاقد أتم ثثلاث سنوات اقامة في البلد. 2-لديـه زوج يحمل جنسية دول الاقامسة ولا يحق للاجئ أن يستفيد من هذا

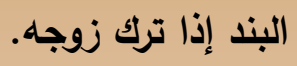

(1) United Nations Treaty Collection, http://treaties.un.org/Pages/ViewDetails.aspx?src=TREATY\&mtdsg_no $=\mathrm{IV}-\mathbf{4} \&$ chapter $=\mathbf{4} \&$ lang $=\mathrm{en}$ 
3-لديه واحد أو أثنين من الأطفال الذين يحملون جنسية الدولـة التي يقيم

فيها.

3- تقوم الدول المتعاقدة بالأخذ في الأعتبار حقوق اللاجئين الخاصـة بأصحاب

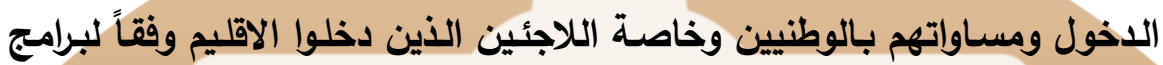

العمالة أو الهجرة. (1) - الهول اعلان أنجولا (1981/6/23):

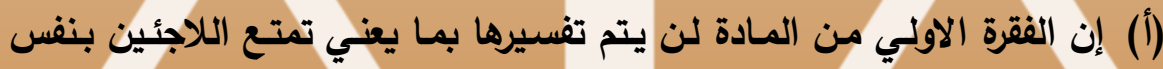

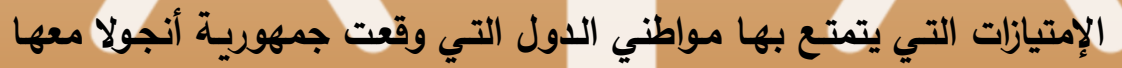

$$
\text { إتفاقيات تعاون. }
$$

(ب)) إن الفقرة الثانية من هذه المادة تفسر علي أنها توصية وليس إلتزام.2

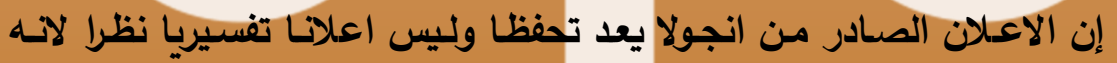

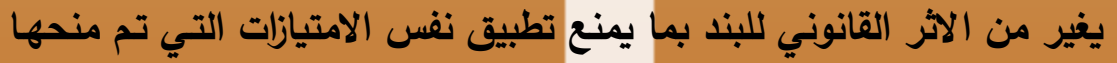

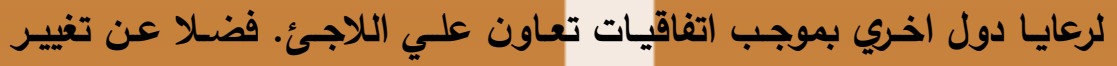

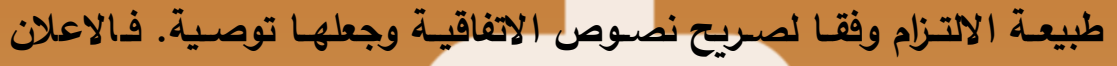

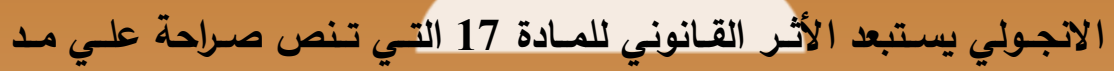

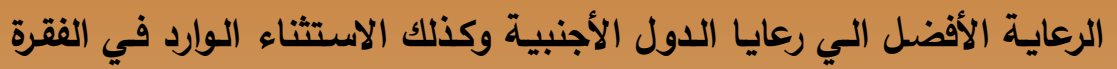

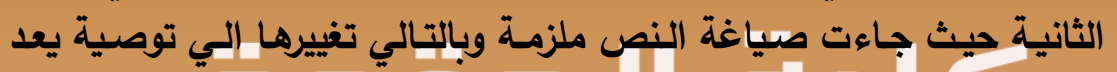
تغييرا للاضر القانوني للنص بما يجعله تحفظا مستترا ولييس اعلانا تفسيريا.

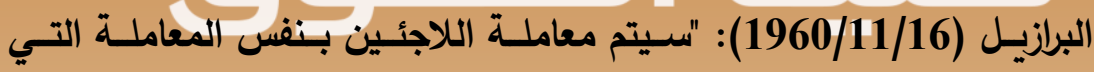

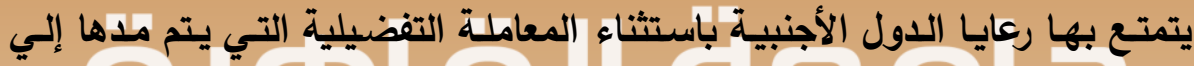

(1) Article 17 of the Convention relating to the status of the refugees, (Geneva 28, 7, 1951). United Nations Treaty Collection, http://treaties.un.org/Pages/ViewDetailsII.aspx?\&src=TREATY\&mtdsg no $=V \sim 2 \&$ chapter $=5 \&$ Temp $=$ mtdsg 2 \&lang $=$ en

(2) United Nations Treaty Collection, http://treaties.un.org/Pages/ViewDetailsII.aspx?\&src=TREATY \&mtdsg $\underline{\text { no }=V \sim 2 \& \text { chapter }=5 \& \text { Temp }=\text { mtdsg2 \&lang }=\text { en }}$ 
مواطني البرتغال وفقاً لاتفاقية الصداقة والاستشارات لعام 1953 والمـادة 199 من

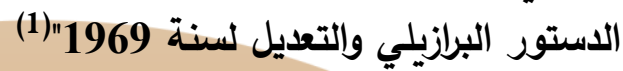

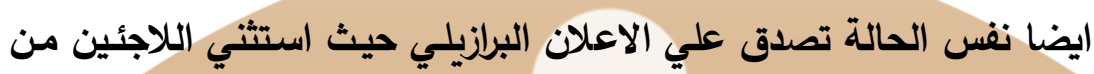

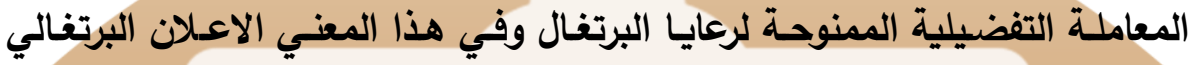
الني سيرد ذكره.

البرتغال 13/(1976/7): " في جميع الحالات التي تمنح المعاهدة اللاجئين

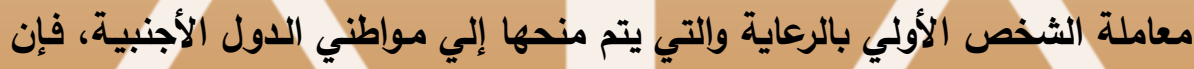

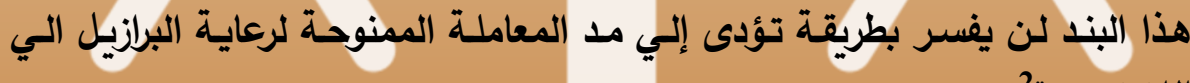
أسبانيا (1978/8/14): " إن تعبير المعاملة الأولي بالرعايا " المستخدم في لوني

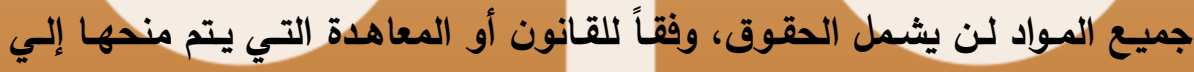

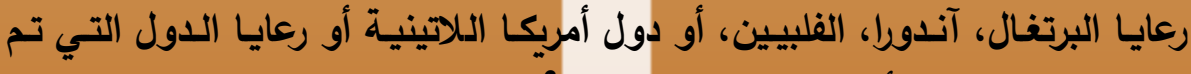

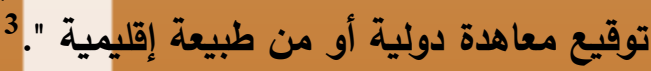

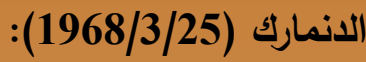

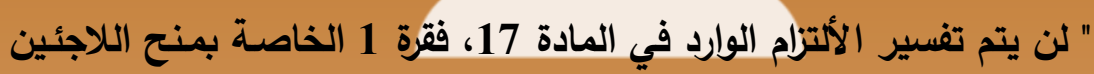

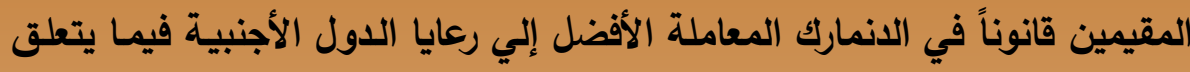

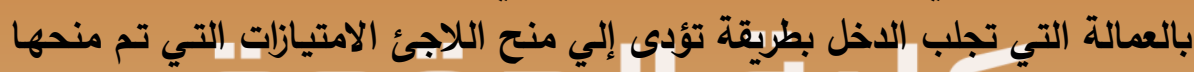

(1) United
Nations $\begin{gathered}\text { Treaty } \\ \text { Collection, }\end{gathered}$ (2) United Nations Treaty Collection, http://treaties.un.org/Pages/ViewDetailsII.aspx?\&src=TREATY\&mtdsg no=V 2\&chapter $=5 \&$ Temp=mtdsg2\&lang $=$ en

(3) United Nations Treaty Collection,http://treaties.un.org/Pages/ViewDetailsII.aspx?\&src=TREA TY\&mtdsg no $=V \sim 2 \&$ chapter $=5 \&$ Temp $=$ mtdsg2\&lang $=$ en 
لرعايا دول فنلندا، أيسلندا، النرويج والسويد".(1)

أما اعلان كل من أسبانيا والدنمارك فلا يمد نطاق المعاملة التفضيلية الي

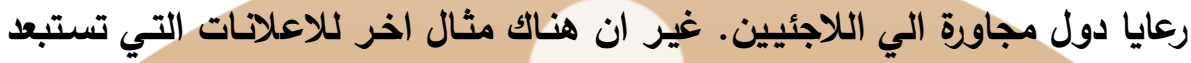

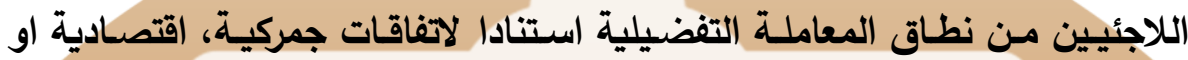
سياسية اقليمية. فالاعلان البلجيكي والكهولندي يشتركان في ذلك أيضا علي النحو

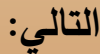
بلجيكا ( 1953/7/22): "في جميع الحالات التي تمد المعاهدة إلي اللاجئين

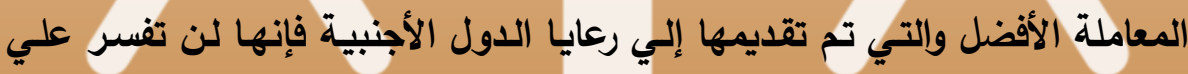

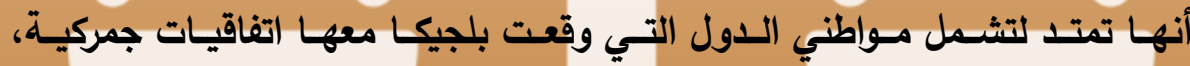
اقتصادية وسياسية إقليمية". هولنـا (1956/5/3): "تخضــع هـــه المـادة للـــفظ الخـاص بـأن جميـع

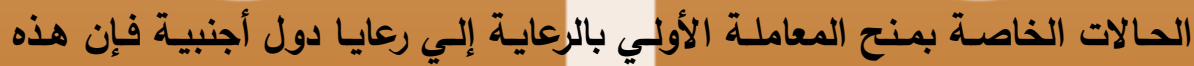

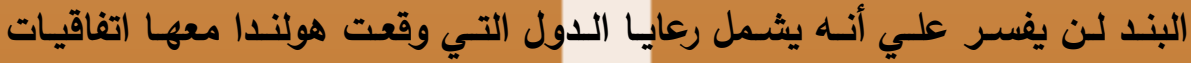

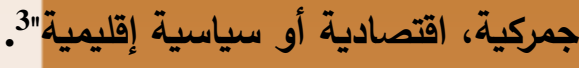

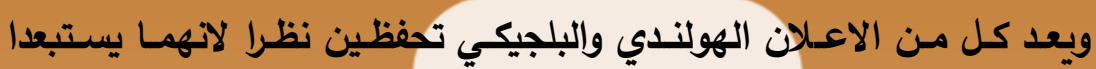

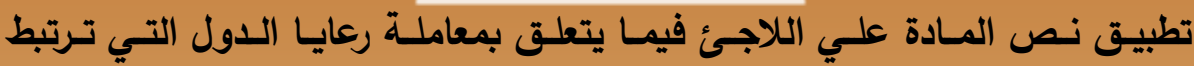
باتفاقات جمركية، اقتصادية أو سياسية.

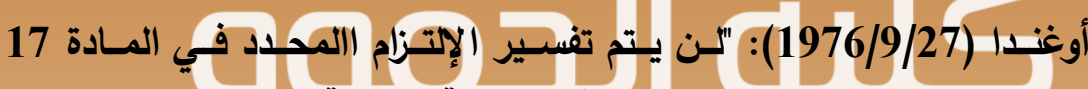

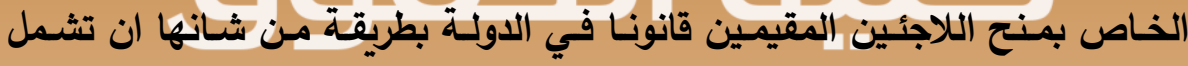

(1) $\begin{gathered}\text { United } \\ \text { Nations }\end{gathered} \begin{gathered}\text { Treaty } \\ \text { Collection, }\end{gathered}$
nttp://treaties.un.org/Pages/ViewDetailsII.aspx?\&src=TREATY\&mtdsg

(2) United Nations Treaty Collection,http://treaties.un.org/Pages/ViewDetailsII.aspx? \&src=TREA TY\&mtdsg_no $=V \sim 2 \&$ chapter $=5 \&$ Temp $=$ mtdsg $2 \&$ lang $=$ en

(3) United Nations Treaty Collection, http://treaties.un.org/Pages/ViewDetailsII.aspx?\&src=TREATY\&mtdsg $\underline{\text { no }=V \sim 2 \& \text { chapter }=5 \& \text { Temp }=\text { mtdsg } 2 \& \text { lang }=\text { en }}$ 
الرعاية الأفضل الممنوحة إلي رعايا الدول التي تتمتع بأمتياز خاص بمعاهدة قائمـة

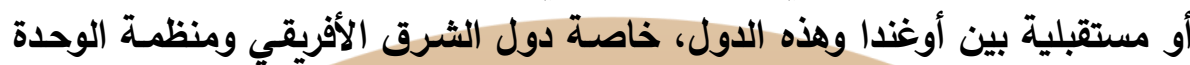

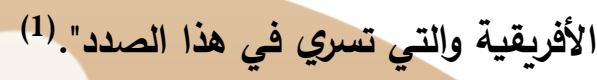

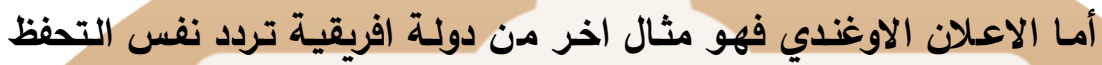
الصادر من كل من هولندا وبلجيكا.

جواتيمالا (1983/9/22): " إن تعبير " المعاملة الأفضل الوارد في المعاهدة

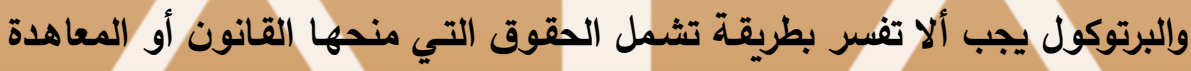

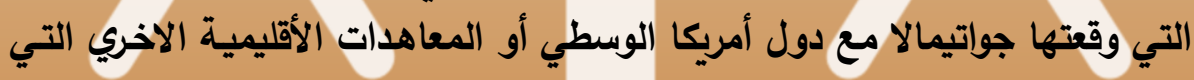

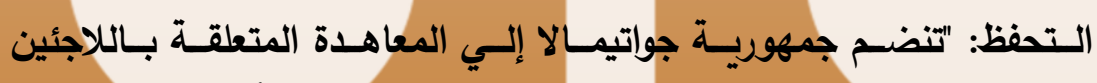

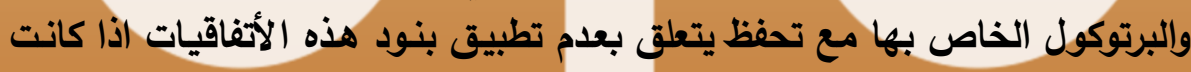

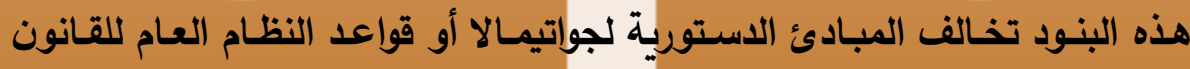

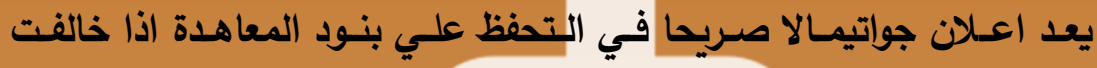

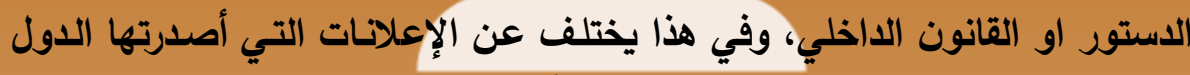

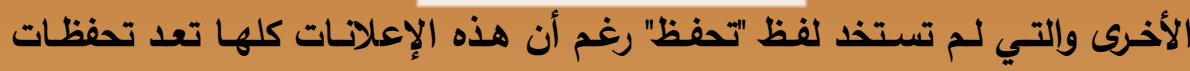

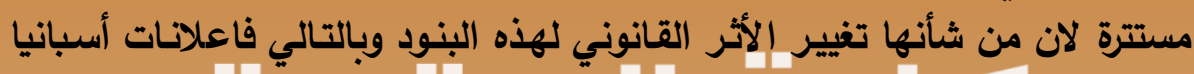

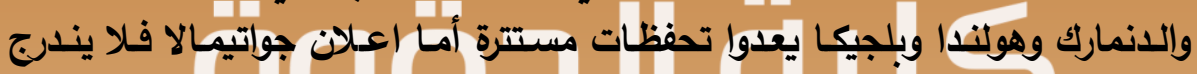

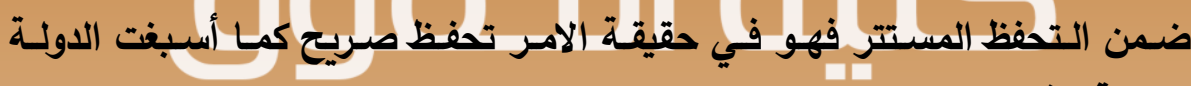

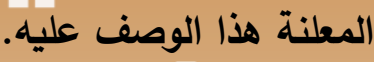

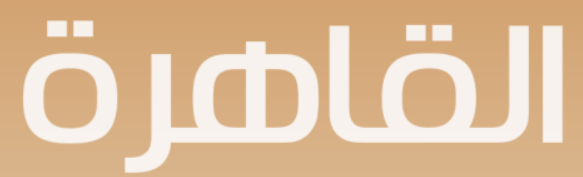

(1)

United

Nations

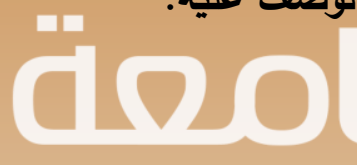

(1) http://treaties.un.org/Pages/ViewDetailsII.aspx?\&src=TREATY\&mtdsg no $=V \sim 2 \&$ chapter $=5 \&$ Temp $=$ mtdsg 2\&lang $=$ en

(2) United Nations Treaty Collection, http://treaties.un.org/Pages/ViewDetailsII.aspx?\&src=TREATY\&mtdsg $\underline{\text { no }=V \sim 2 \& \text { chapter }=5 \& \text { Temp }=\text { mtdsg2 \&lang }=\text { en }}$ 


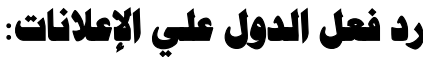

لوكسمبورج (1984/11/15):"تعتبر ان التحفظ المتعلق بجواتيمـالا الموقع

في 1951/7/28 والبرتوكول لايمس التزامات جواتيمالا بموجب هذه الإتفاقية ". ألمانيا (1984/12/5): "تعتبر التحفظ الصـادر من جواتيمالا قد تم صياغته بشكل عام للفاية وبالتالي فتطبيقه يؤدى إلي إبطال بنود المعاهدة والبرتوكول ولذبلك

فإن التحفظ لا يمكن أن يقبل". 1

إيطاليا (1984/11/26): "تعتبر التحفظ الصـادر من جواتيمـالا غير مقبول

نظراً لأن بنوده عامة ومصاغة بثكل عام كما أنه يشير في كثير منـه إلـي القانون

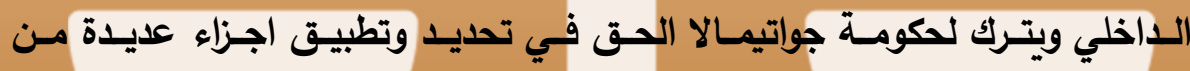

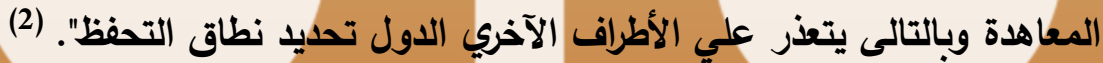
هولندا (1984/12/11): "تعتبر التحفظ الصادر من جواتيمالا مصاغ بثكل عام ويرجع إلي القانون الداخلي ولذلك فهو غير واضتح".

زامبيا (1969/9/24): "لا تعتبر نفسها ملزمـة بمـنح اللاجئ الـذي تنطبق

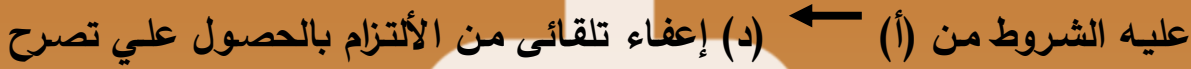

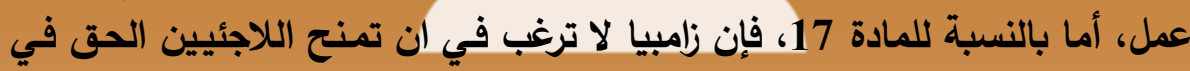

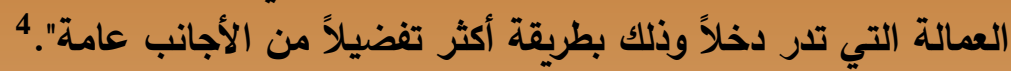

(1) United

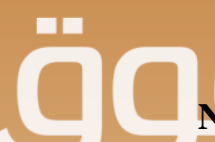
Nations

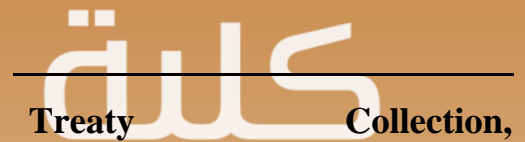
http://treaties.un.org/Pages/ViewDetailsII.aspx?\&src=TREATY \&mtdsg $\_n o=V \sim 2 \&$ chapter $=5 \&$ Temp $=$ mtdsg2 \&lang $=$ en

(2)

2 United Nations Treaty Collection, http://treaties.un.org/Pages/ViewDetailsII.aspx?\&src=TREATY\&mtdsg $\_$no $=V \sim 2 \&$ chapter $=5 \&$ Temp $=$ mtdsg2 \&lang $=$ en

(3) United Nations Treaty Collection, http://treaties.un.org/Pages/ViewDetailsII.aspx?\&src=TREATY \&mtdsg $\_$no $=V \sim 2 \&$ chapter $=5 \&$ Temp $=$ mtdsg2\&lang $=$ en

(1) United Nations Treaty Collection, http://treaties.un.org/Pages/ViewDetailsII.aspx?\&src=TREATY\&mtdsg $\_n o=V \sim 2 \&$ chapter $=5 \&$ Temp $=$ mtdsg $2 \&$ lang $=$ en 
وبملاحظة الإعلانـات المختلفـة والعديدة التي أوردتها الدول فيما يتعلق بالمـادة

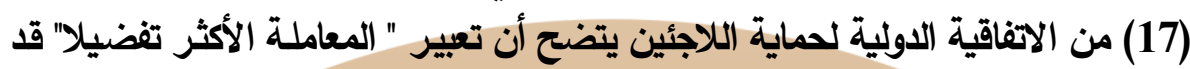

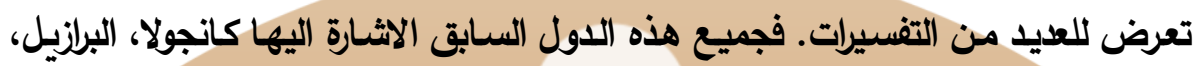
البرتغال، اسبانيا، الدنمارك، بلجيكا واوغندا لا تمد الرعاية الافضل الي اللاجئين. فالمعاملات التفضيلية التي تم تقديمها إلي دول البلقان، الدول الأفريقية،

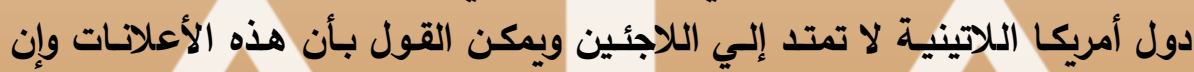

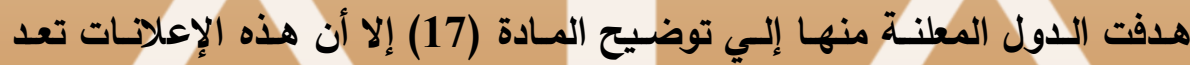

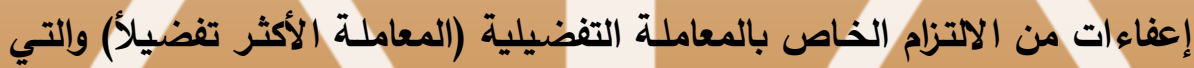
يجب منحها إلي اللاجئ لذلك فهذه الاعلانات تعد تحفظات مستترة. إن التفسير المنطقي للمـادة (17) يثير إلي بنود ملزمـة فهي تحمل صيغة

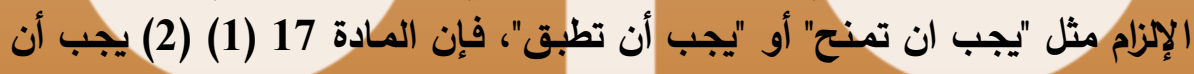

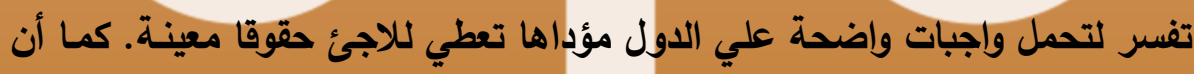

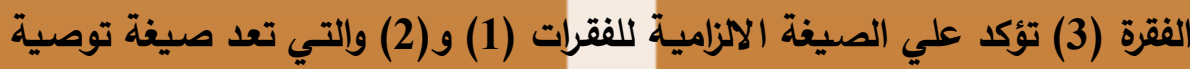

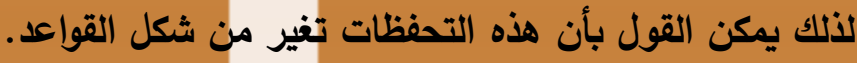

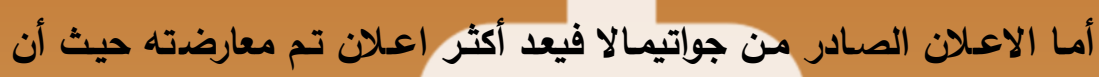

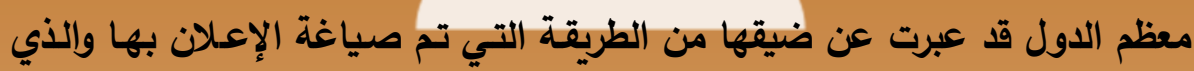

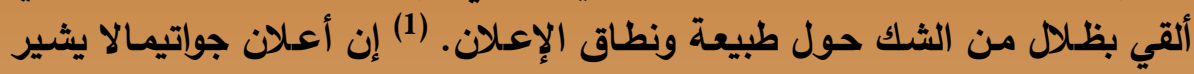

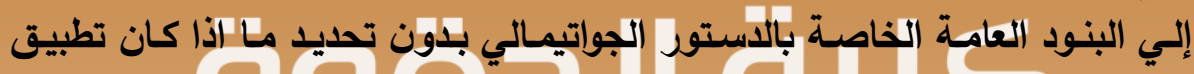
إنه ليس من المستحيل القول بأن الاستور ليس لـه أي تأثثر علي المي المـادة

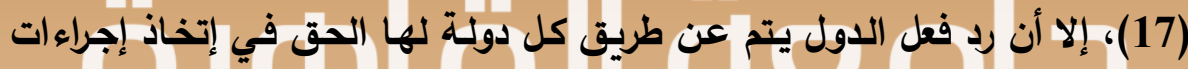

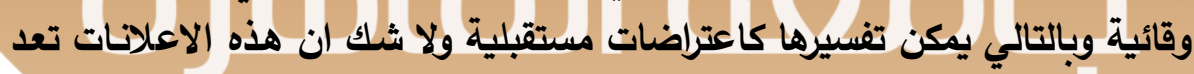
في حقيقة الامر تحفظات نظرا لانها تعدل من الاثر القانوني لبنود المعاهدة.

(1) United Nations Treaty Collection, http://treaties.un.org/Pages/ViewDetailsII.aspx?\&src=TREATY \&mtdsg $\_$no $=V \sim 2 \&$ chapter $=5 \&$ Temp $=$ mtdsg2\&lang $=$ en 
و قد أسترعي التحفظ الذي أصدرته جواتيمـالا كل ردود الأفعال هذه لاتها

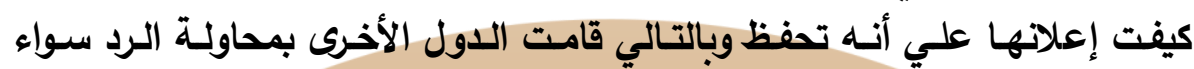

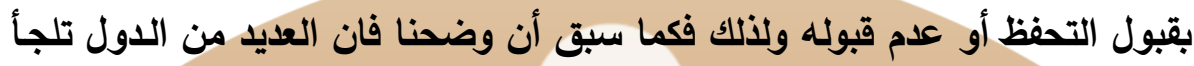

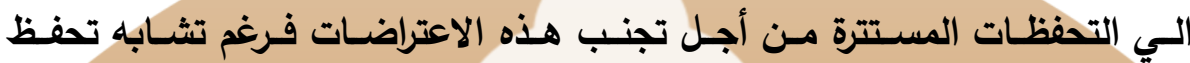

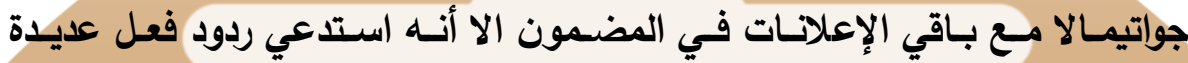
واعتراضات من الدول لاتها استخدمت كلمة تحفظ. (6) الاتفاقية الدولية الغاصة بمنظمة البمار (الدولية (بنيف 1948/3/6): تنص المـادة (أ) (ب) علي: "يجب علي المكومـات أن تزيـل كافة الأعمـال

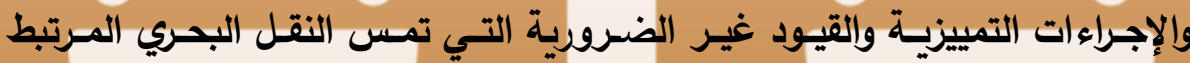

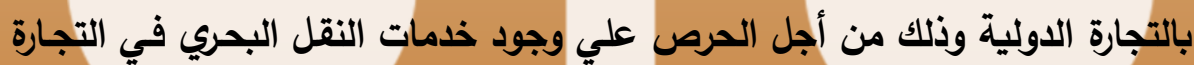

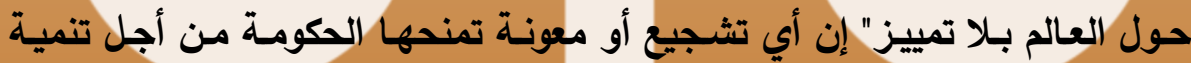

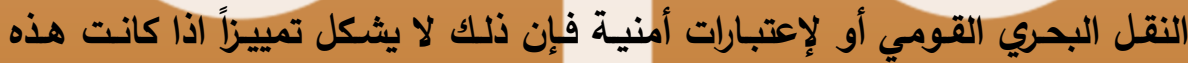

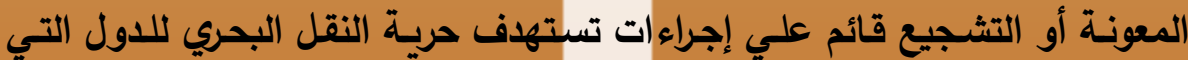

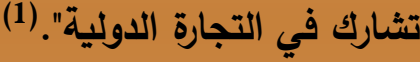
الإعلانات التي أصدرتها الدول المختلفة:

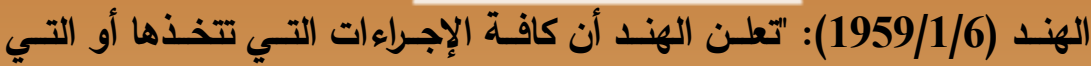

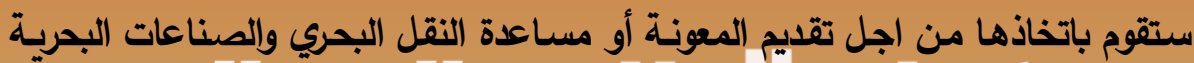

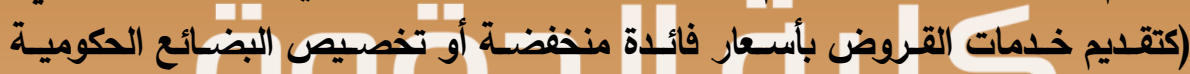

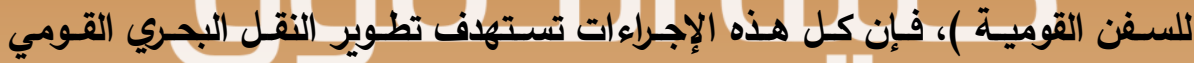

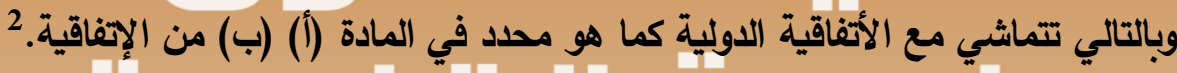

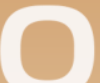

(1) Art. 1 (b) of the convention on the international maritime organization. United Nations Treaty Collection, http://treaties.un.org/Pages/ViewDetails.aspx?src=TREATY\&mtdsg_no $=$ XII-1\&chapter $=12 \&$ lang $=$ en

(2) United Nations Treaty

Collection,http://treaties.un.org/Pages/ViewDetails.aspx?src=TREATY \&mtdsg_no=XII-1\&chapter $=12$ \&lang $=$ en 
وبالتالي فإن التوصيات الصـادرة من المنظمـة ستخضـع لرقابـة حكومـة الهند

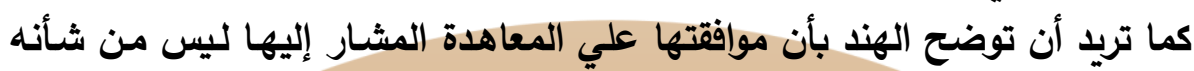

تفيير أو تعديل أي قانون ساري في إقليم التهند". 1

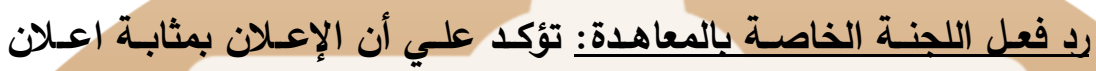

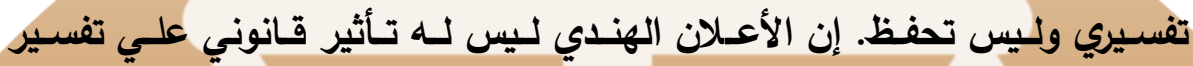

المعاهدة الخاصة بمنظمة البحار الدولية.

إعلان اضافي (1962/1/31): "توافق علي أن الجزء الأول من الاعلان لـه

طبيعة سياسية وبالتالي فإنه ليس لله تأثير قانوني فيما يتعلق بتفسير المعاهدة. 3

المملكة المتحدة (1961/9/14) / النرويج (1962/3/14): "تعتبر الاعلان

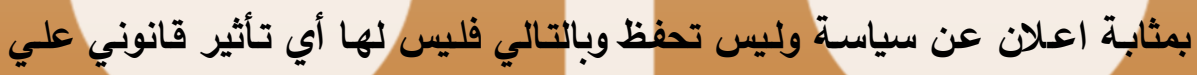

تفسير المعاهدة وذلك وفقاً لقرار مجلس المنظمة الدولية لدية للبحار". 4

الولايـات المتحـدة (1962/9/5): "لـن تعتـرض علـي بنـود قبـول اندونيسيا

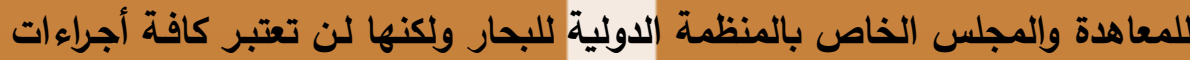

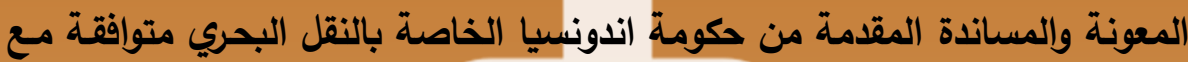

المعاهدة.

كوبا (1966/5/6):"عند قبول هذه المعاهدة فإن الحكومة الثوريـة لجمهوريـة

(1) United Nations Treaty Collection, http://treaties.un.org/Pages/ViewDetails.aspx?sre=TREATY\&mtdsg_no =XII-1\&chapter=12\&lang=en

(2) United Nations Treaty Collection, http://treaties.un.org/Pages/ViewDetails.aspx?src=TREATY\&mtdsg_no $=X I I-1 \&$ chapter $=12 \&$ lang $=$ en

(3) United Nations Treaty Collection, http://treaties.un.org/Pages/ViewDetails.aspx?src=TREATY\&mtdsg_no $=$ XII-1\&chapter=12\&lang=en

(4)http://treaties.un.org/Pages/ViewDetails.aspx?src=TREATY \&mtdsg_no $=$ XII-1\&chapter $=12 \&$ lang $=$ en

(5)http://treaties.un.org/Pages/ViewDetails.aspx?src=TREATY\&mtdsg_no $=X I I-1 \&$ chapter $=12 \&$ lang $=$ en 
كوبـا تعلن ان التشربع الحالى الذى يهدف إلي تشجيع وتطوير الأسطول البحري،

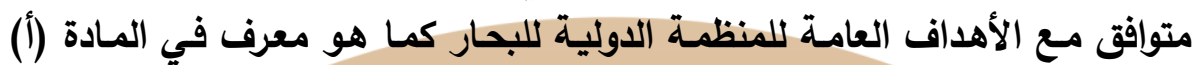

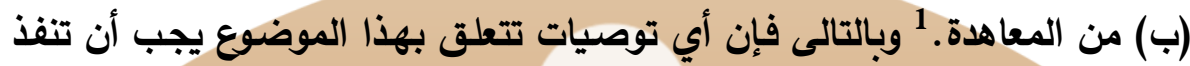

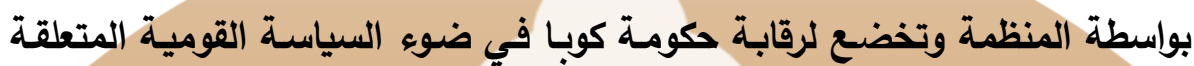
بهذا الموضوع.

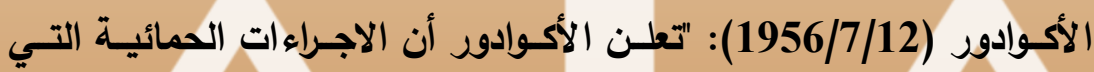

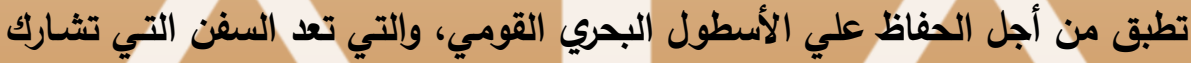

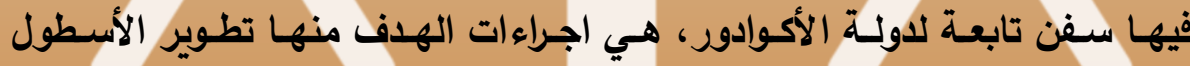

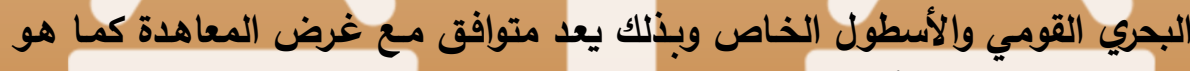

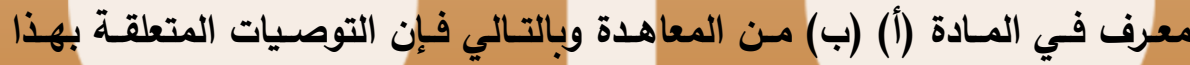
الموضوع يجب أن تخضع لمكومة الأكوادور. 2

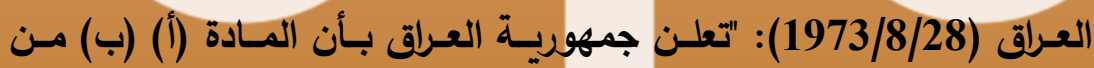

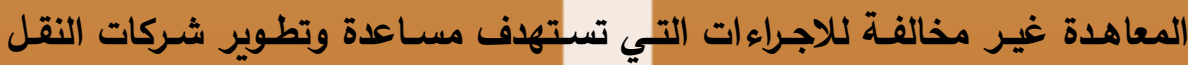
القومي، والخاصة بتقديم قروض أو أي أجراءات اخري تتعلق بالأسطول القومي". 3 المكسيك (1954/9/21): إن حكومـة المكسيك في قبولها للمعاهده الدولية

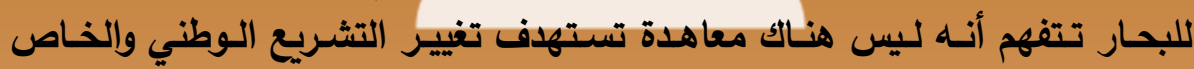

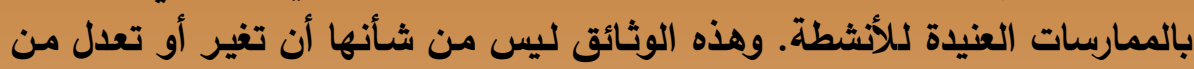
تطبيق القوانين الخاصة بالاحتكارات في دولة المكسيك". 4 الولايات المتحدة (1950/8/17): "لن يتم فهم هذه المعاهدة بطريقة تؤدى المي

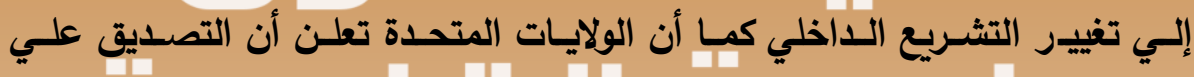

(1)http://treaties.un.org/Pages/ViewDetails.aspx?src=TREATY\&mtdsg_no $=$ XII-1\&chapter $=12 \&$ lang $=$ en

(2)http://treaties.un.org/Pages/ViewDetails.aspx?src=TREATY\&mtdsg_no $=$ XII-1\&chapter=12\&lang=en

(3)http://treaties.un.org/Pages/ViewDetails.aspx?src=TREATY\&mtdsg_no $=$ XII-1\&chapter $=12 \&$ lang $=$ en

(4)http://treaties.un.org/Pages/ViewDetails.aspx?src=TREATY\&mtdsg_no $=$ XII-1\&chapter=12\&lang=en 
المعاهدة لن يجعل المعاهده تغير من تطبيق قوانين منع الاحتكار السـارية في

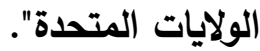

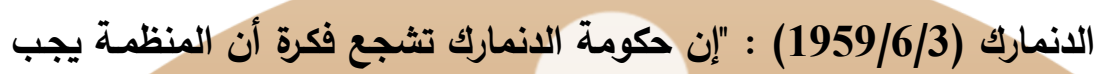

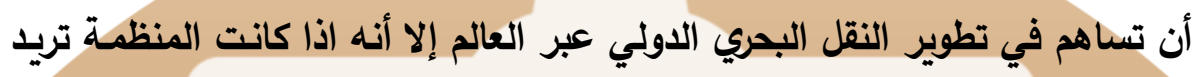

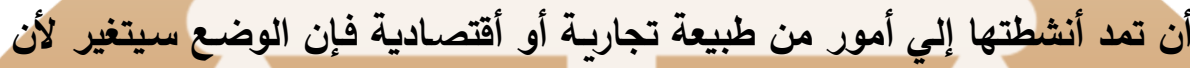

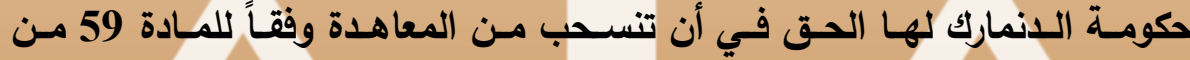

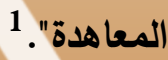

بإستقراء حالات الاعلانات الصادرة من الهند وباقي الدول فإنه يمكن القول

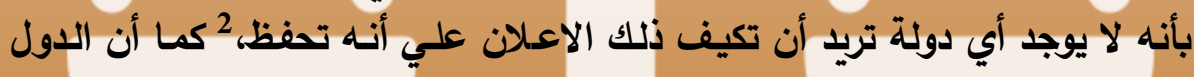

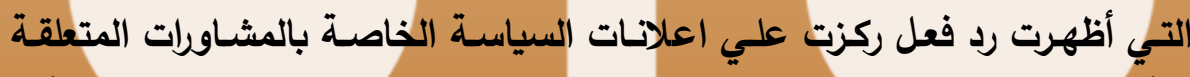

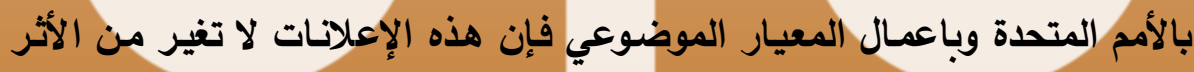

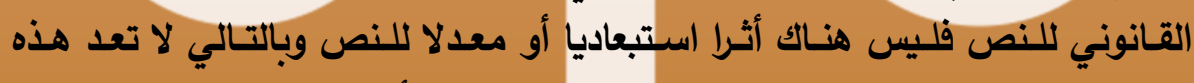

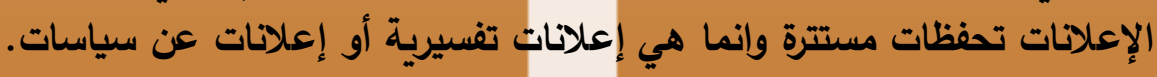

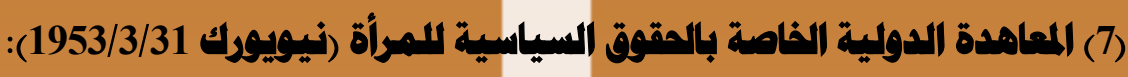

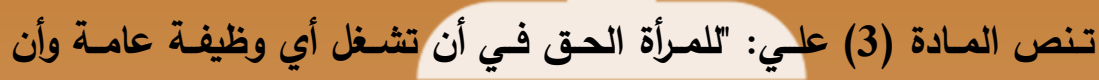

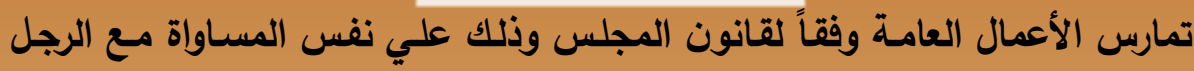
بدون أي تمييز".

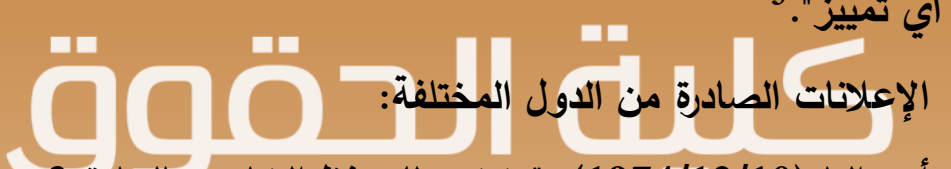
أستراليا (1974/12/10): "تخضع للتحفظ الخاص بالمسادة 3 من المعاهدة

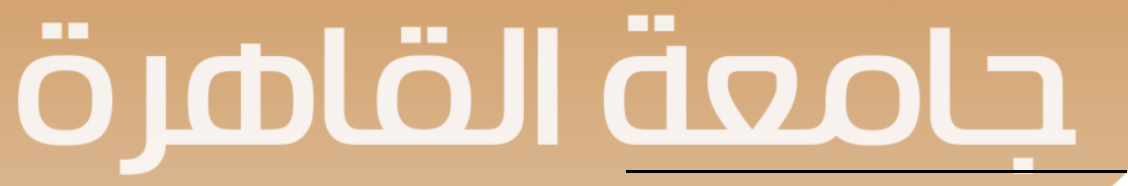

(1)http://treaties.un.org/Pages/ViewDetails.aspx?src=TREATY \&mtdsg_no $=$ XII-1\&chapter=12\&lang=en

(2)http://treaties.un.org/Pages/ViewDetails.aspx?src=TREATY\&mtdsg_no $=$ XII-1\&chapter $=12 \&$ lang $=$ en

(3)http://treaties.un.org/Pages/ViewDetails.aspx?src=TREATY\&mtdsg_no $=$ XVI-1\&chapter $=16 \&$ lang $=\mathrm{en}$ 
والتي لا تنطبق علي التعيين وشروط الاتحاق بالخدمة في قوات الدفاع ". 1 بلجيكا (1964/5/20):"يحفظ الدستور ممارســة السـلطات الملكيـة للرجل،

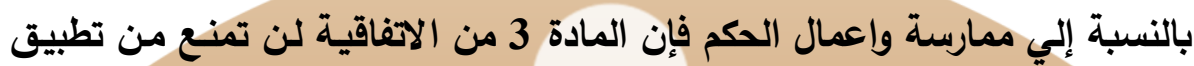

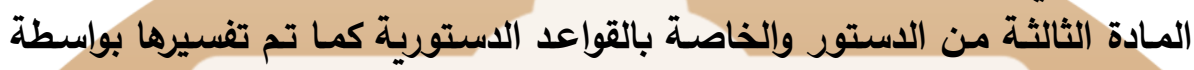
2

الــنمارك (1954/7/7): "خاضـع للـــفظ الخـاص بالمـادة 3 مـن الاتفاقيـة

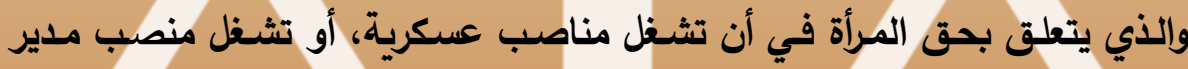
التعيين أو تصبح عضو في مجلس التعيين.

فنلنــا (1958/10/6): "يمكـن أن يصـدر قـرار مـن شـأنه تعيـين المـرأة أو الرجل فقط في بعض الوظائف، والتي بسبب طبيعتها، يمكن أن تنفذ فقط بواسطة فئه

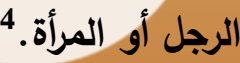

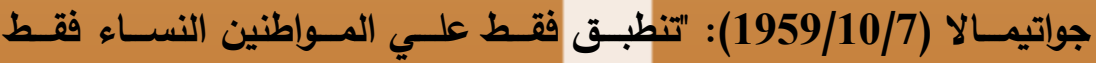

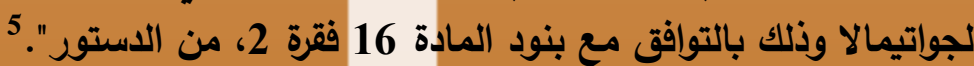

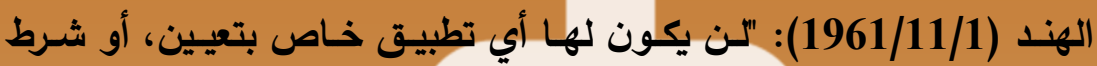

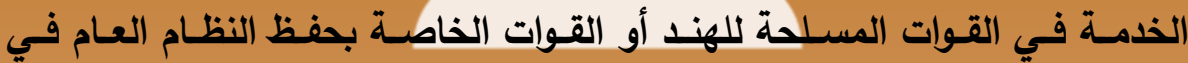
الهند".

(1)http://treaties.un.org/Pages/ViewDetails.aspx?src=TREATY\&mtdsg_no $=$ XVI-1\&chapter $=16 \&$ lang $=$ en

(2)http://treaties.un.org/Pages/ViewDetails.aspx?src=TREATY\&mtdsg_no $=\mathrm{XVI}-1 \&$ chapter $=16 \&$ lang $=\mathrm{en}$

(3)http://treaties.un.org/Pages/ViewDetails.aspx?src=TREATY\&mtdsg_no $=$ XVI-1\&chapter $=16$ \&lang $=$ en

(4)http://treaties.un.org/Pages/ViewDetails.aspx?src=TREATY\&mtdsg_no $=$ XVI-1\&chapter $=16 \&$ lang $=$ en

(5)http://treaties.un.org/Pages/ViewDetails.aspx?src=TREATY\&mtdsg_no $=X V I-1 \&$ chapter $=16 \&$ lang=en

(6)http://treaties.un.org/Pages/ViewDetails.aspx?src=TREATY \&mtdsg_no $=X V I-1 \&$ chapter $=16 \& l a n g=e n$ 
تثترك الاربع دول (استراليا، بلجيكا، الدنمارك والهند) في ابداء تحفظ علي

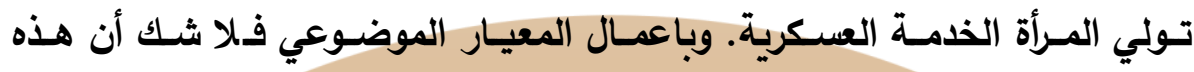

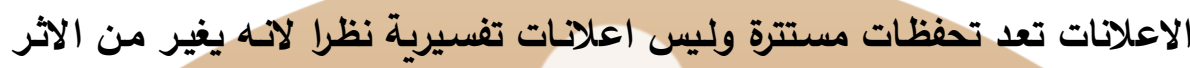

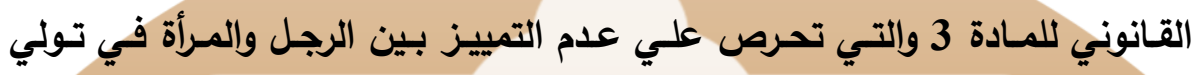

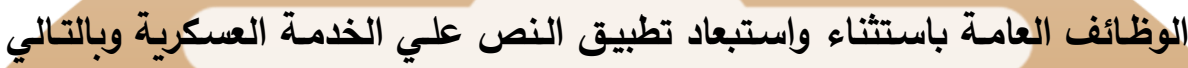
فانها تحفظات مستترة.

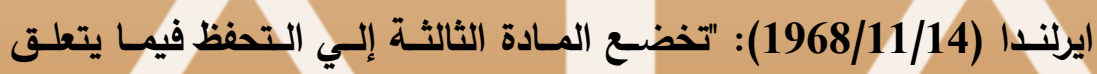

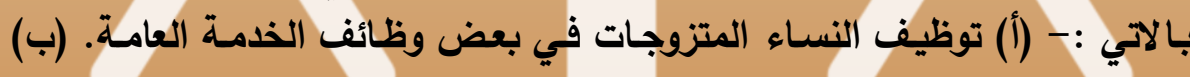

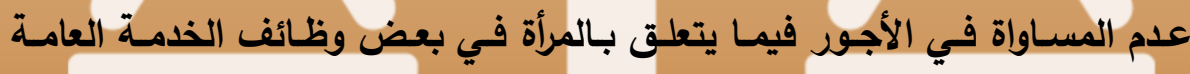

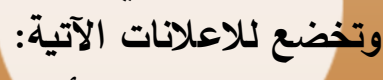

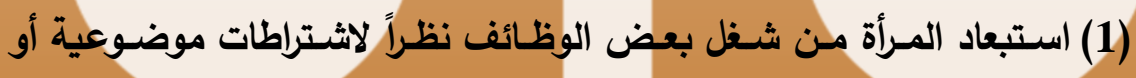

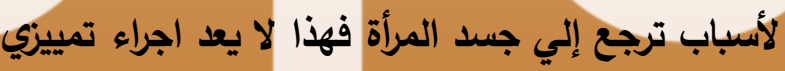

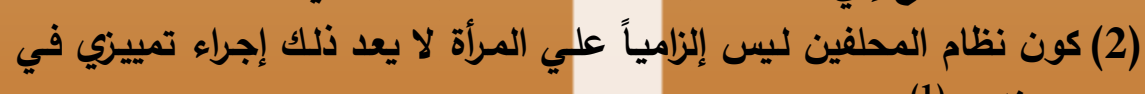

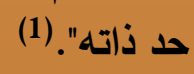

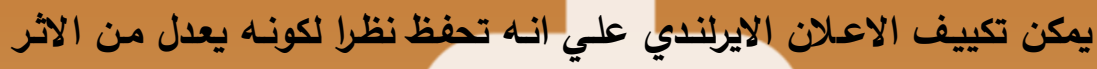

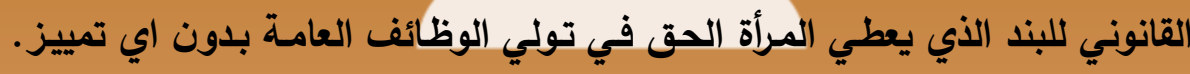

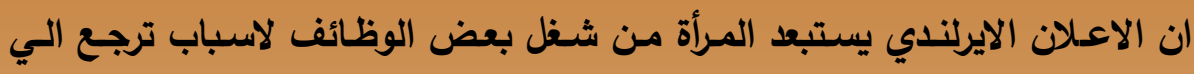

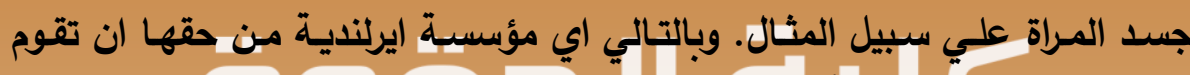

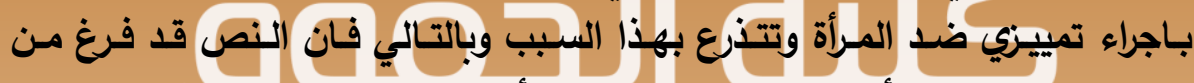

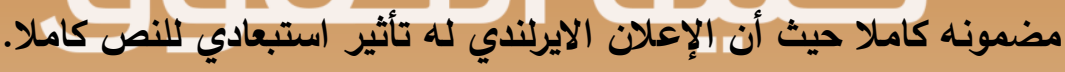

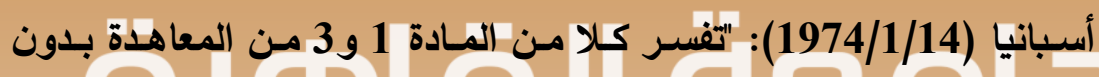

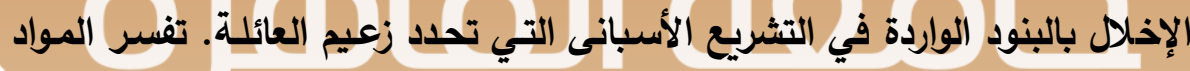

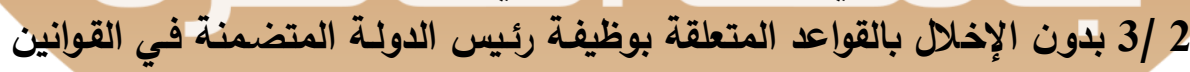

(1)http://treaties.un.org/Pages/ViewDetails.aspx?src=TREATY\&mtdsg_no $=X V I-1 \&$ chapter=16\&lang=en 


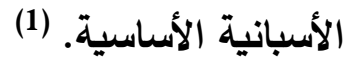

تفسر المادة 3 بدون الإخلال بالحقيقة الماثلة وهي أن بعض الوظائف نظراً

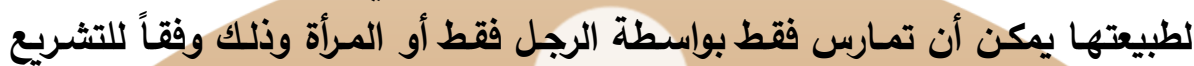

الأسباني"(2)

رد فعل تثيكوسلوفاكيا: "تعترض علي التحفظ المبدي من حكومـة أسبانيا

فيما يتعلق بالمواد 1،2،3 بناءاً علي أنها لا تتفق مع أغراض الإتفاقية.

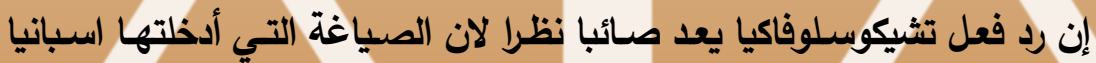

مطاطة للفاية ويمكن تفسيرها بطريقة تؤدي الي تغيير الاثر القانوني للبند المثار اليها.

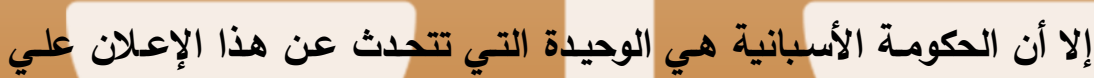

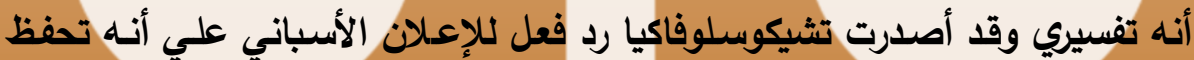

وليس اعلان تفسيري. ولا شك أن الإعلان الاسباني هو تحفظ مستتر أيضا.

(8) الفاقية القهوة الدولية (نيويورك 1962/9/28):

تنص المادة 47 (3) (إزاحة بعض معوقات استهلاك القهوة ) علي الآتي:

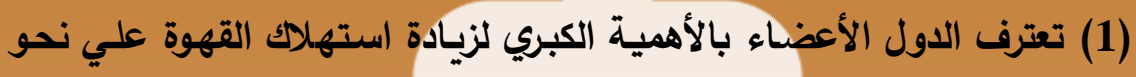

متسارع وذلك بالتخلص من كافة العوائق التي تمنع هذه الزياءة الأيادة.

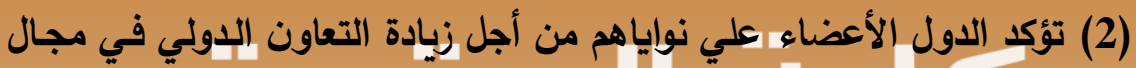

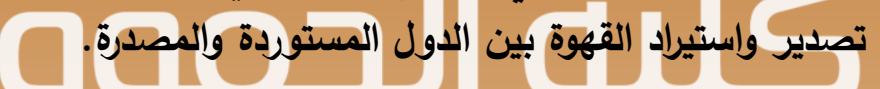

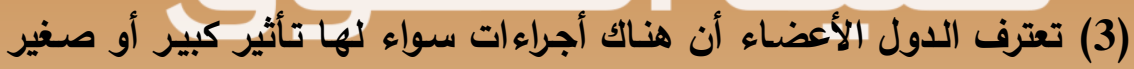

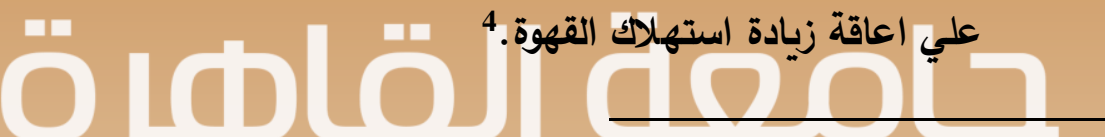

(1)http://treaties.un.org/Pages/ViewDetails.aspx?src=TREATY\&mtdsg_no $=$ XVI-1\&chapter $=16 \&$ lang $=$ en

(2)http://treaties.un.org/Pages/ViewDetails.aspx?src=TREATY \&mtdsg_no $=$ XVI-1\&chapter $=16 \&$ lang $=$ en

(3)http://treaties.un.org/Pages/ViewDetails.aspx?src=TREATY\&mtdsg_no $=X V I-1 \&$ chapter $=16 \& l a n g=e n$

(4) Article 47 (3) of the International Coffee Agreement 


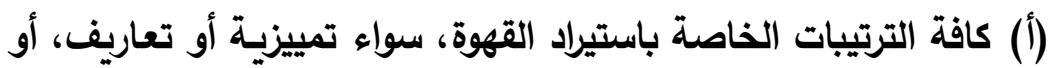

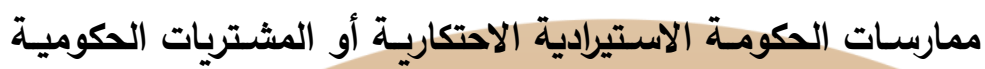

وباقي القواعد الاداريـة والممارسات التجاربية. 1

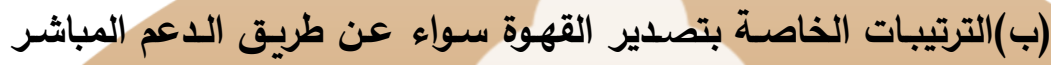

وغير المباشر وأيضاً القواعد الادارية والممارسات التجارية.

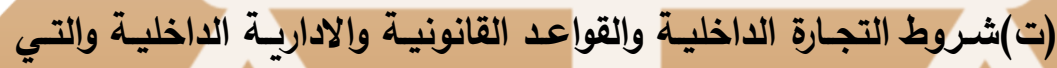

تؤثر علي الاستهلاك.

اعلانات الدول الإتافة:

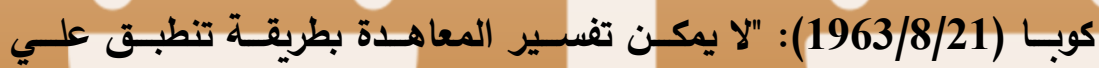

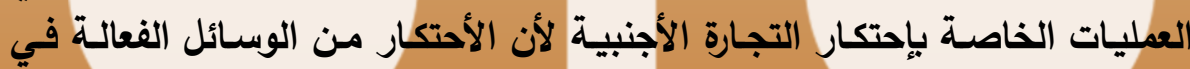

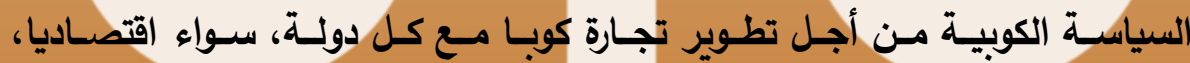

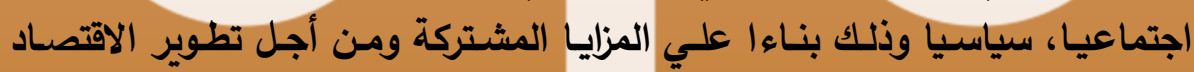

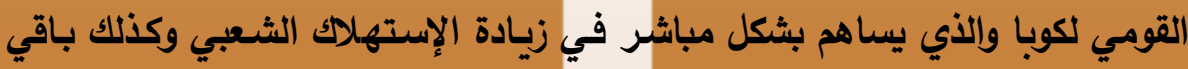
السلع الأساسية.

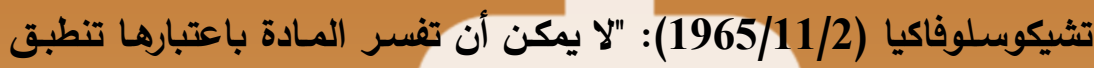

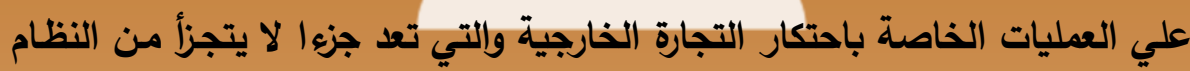

الإقتصادي والقانونى لجمهورية تشيكوسلوفاكيا الاثتراكية". 3

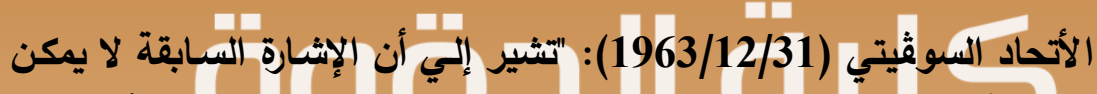

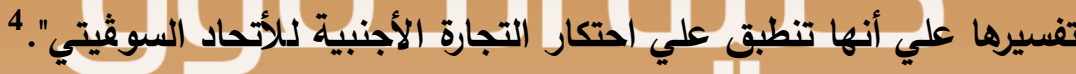

$\square$

(1)http://treaties.un.org/Pages/ViewDetails.aspx?src=TREATY \&mtdsg_no =XIX-4\&chapter=19\&lang=en United Nations Treaty Collection,

(2)http://treaties.un.org/Pages/ViewDetails.aspx?src=TREATY\&mtdsg no $=\mathrm{XIX}-4$ \& chapter $=19$ \&lang $=\mathrm{en}$

(3)http://treaties.un.org/Pages/ViewDetails.aspx?src=TREATY\&mtdsg_no $=X I X-4 \&$ chapter $=19$ \&lang=en

(4)http://treaties.un.org/Pages/ViewDetails.aspx?src=TREATY\&mtdsg_no $=$ XIX-4\&chapter $=19 \&$ lang $=$ en 
وبتحليل الاعلانـات السـابقة الثلاثتة، يتضـح أن كل من هذه الاعلانـات يعد

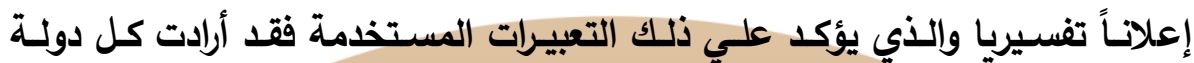

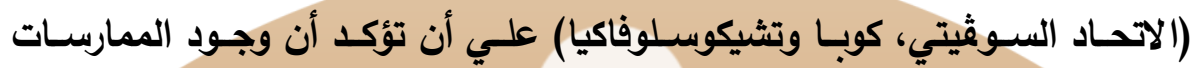

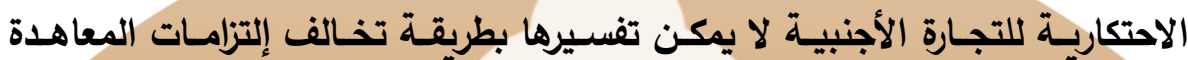

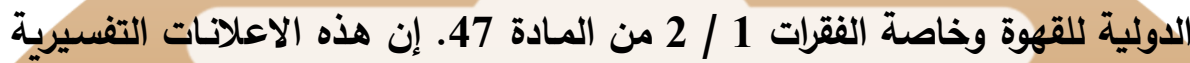

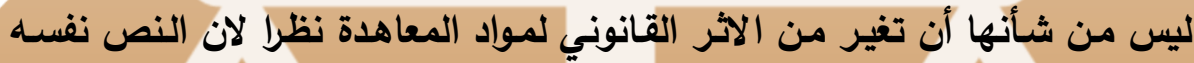

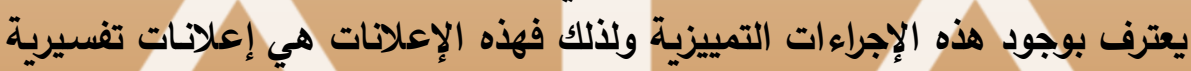

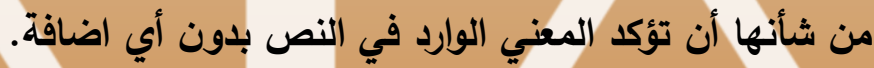

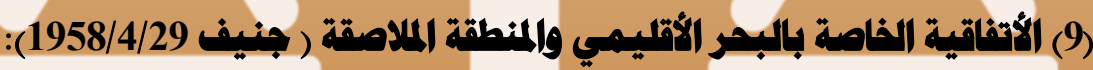

$$
\text { تنص المادة } 24 \text { (1) علي الاتي: }
$$

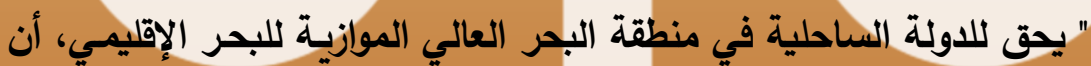

$$
\text { تمارس رقابتها اللازمة وذلك من أجل: }
$$

(1) منع أي اعتداء علي الجمارك، اللوائح المالية، لـوائح الهجرة أو الللوائح

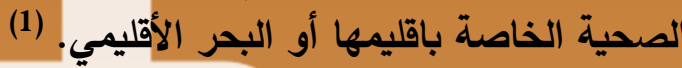

(ب) المعاقبة علي أي مخالفة للوائح المشار اليها والتي ترتكب في إقليمها

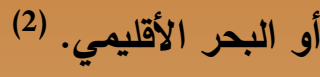

إيطاليا (1964/12/27): "بجانب ممارسـة الرقابـة مـن أجلـ أغراض المـادة

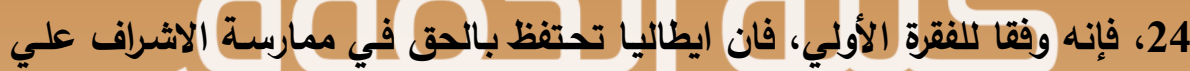

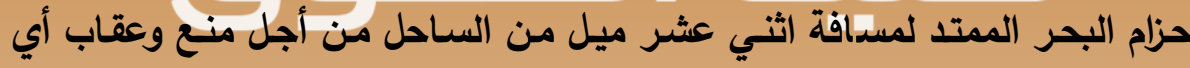

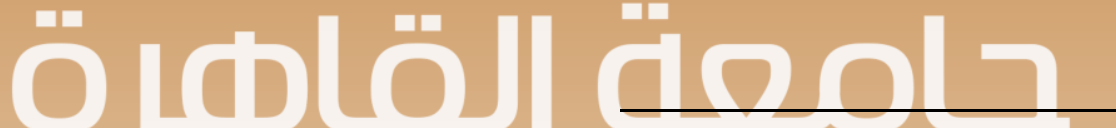

(1) Art. 24 (1) of the Convention on the Territorial Sea \& the Contiguos Zone. United Nations Treaty Collection, http://treaties.un.org/Pages/ViewDetails.aspx?src=TREATY\&mtdsg_no =XXI-1\&chapter=21\&lang=en

(2)United Nations

Treaty

Collection,

http://treaties.un.org/Pages/ViewDetails.aspx?src=TREATY\&mtdsg_no =XXI-1\&chapter $=21 \&$ lang $=$ en 
مخالفة للوائح الجمركية في اي جزء من الحزام قد تقع المخالفة فيه."1

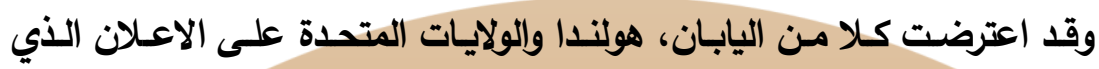

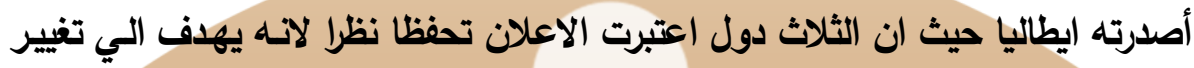

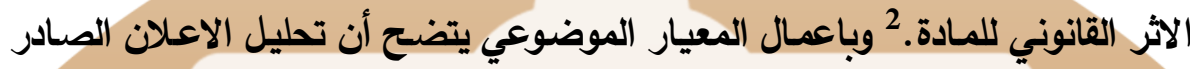

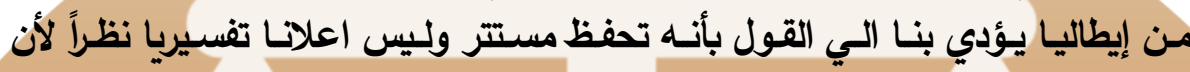

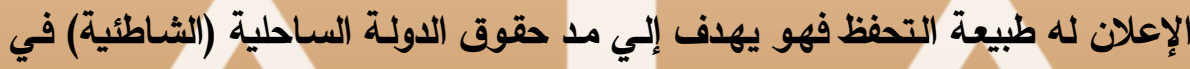

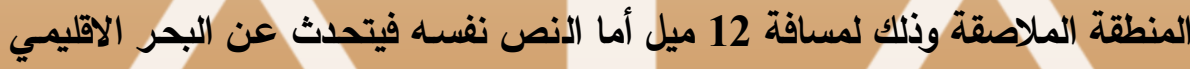

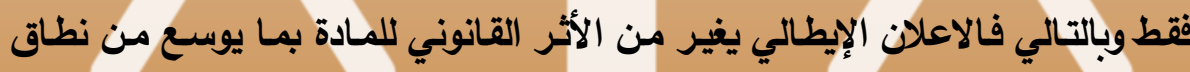

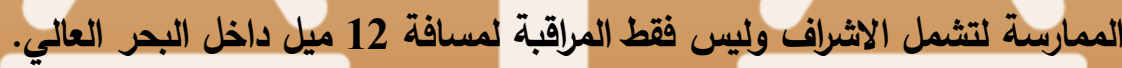

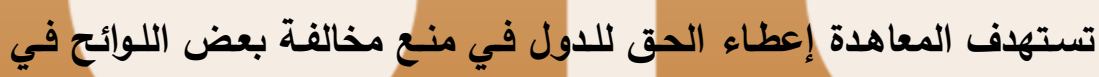

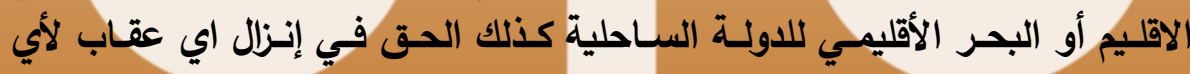
مخالفة لهذه اللوائح سواء في البحر الإقليمي أو الدولية الساحلية.

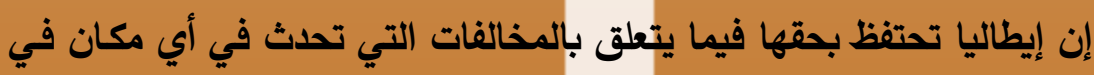

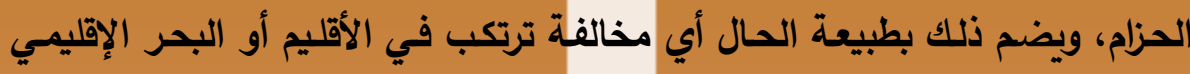

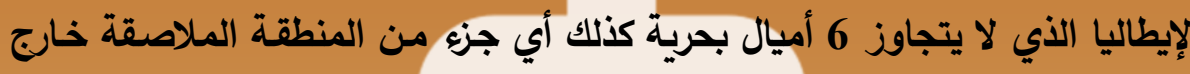

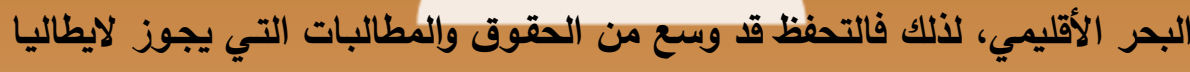

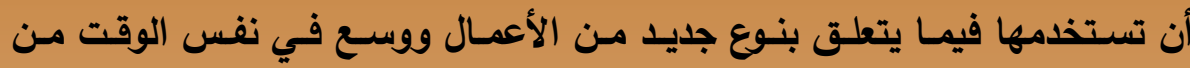

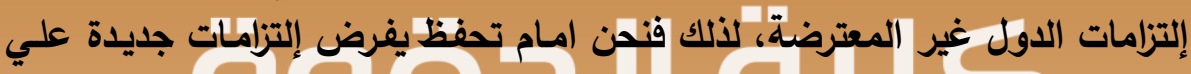
الدول الموقعة علي الاتفاقية.3 3

(1) United Nations Treaty Collection, http://treaties.un.org/Pages/ViewDetails.aspx?src=TREATY\&mtdsg_no =XXI-1\&chapter=21\&lang=en

(2) United Nations Treaty Collection, http://treaties.un.org/Pages/ViewDetails.aspx?src=TREATY\&mtdsg_no =XXI-1\&chapter=21\&lang=en

(3) United Nations Treaty Collection, http://treaties.un.org/Pages/ViewDetails.aspx?src=TREATY\&mtdsg_no =XXI-1\&chapter=21\&lang=en 


\section{(10) معاهدة الرصيف القاري (جنيف 1958/4/29):}

$$
\text { تنص المادة (1) من المعاهدة علي الآتي: }
$$

"يقصد بالرصيف القاري من اجل أغراض هذه المواد الآتي:

قاع البحر والقاع الموازي للسـاحل ولكن خارج منطقة البحر الإقليهي

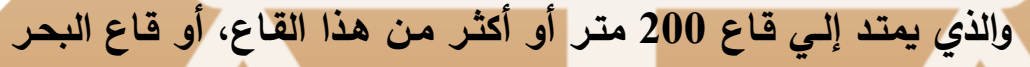

الموازي والخاص باستقلال الموارد الطبيعية لهذه المناطق.

(ب) قاع البحر وقاع المناطق الآخري الموازيـة لساحل الثواطئ. (1)

فرنسـ 1965/6/17): "إن تعبيـر " مــوازي " يتضـمن مفهـوم جيوفيزيـائي،

جيولوجي، وجغرافي يقصد به إمتداد غير محدود للرصيف القاري". 2

و قد قامت كل من كندا، اسبانيا، المملكة المتحدة والولايات المتحدة بحفظ موقفهم فيما يتعلق باعلان فرنسا.

إن التحفظات علي المـادة الأولي من معاهدة الرصيف القاري غير مسموح

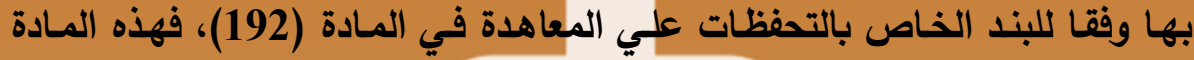

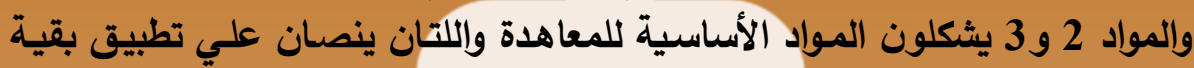

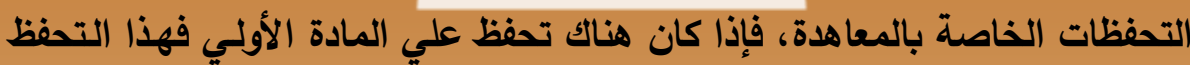
في مضدونها ولاغياً وغير نافة. ولقد قامت سبعة من الدول بحفظ مصالحها وذلك بالنص علي حفظ موقفها.

(1) Article (1) of the convention on the continental shelf. United Nations Treaty Collection, http://treaties.un.org/Pages/ViewDetails.aspx?src=TREATY\&mtdsg no =XXI-4\&chapter=21\&lang=en

(2) United Nations Treaty Collection, http://treaties.un.org/Pages/ViewDetails.aspx?src=TREATY\&mtdsg_no =XXI-4\&chapter $=21 \&$ lang $=$ en 


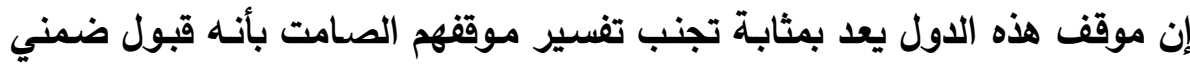

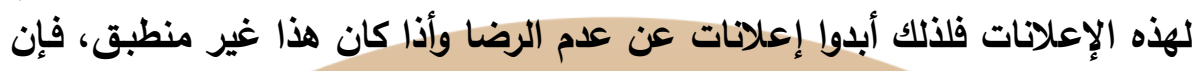
الإعلانات التفسيرية تعد تحفظات.

ولذلك فقد نادت تايلند بأن الاعلان التفسيري يعد تحفظا وباعتراض تايلند

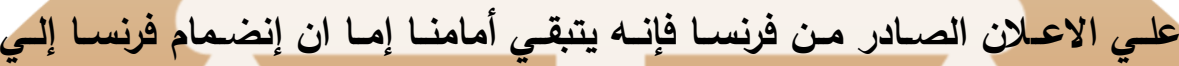

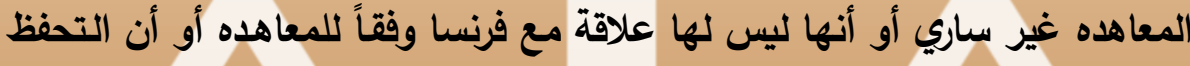

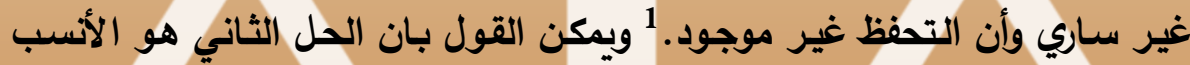

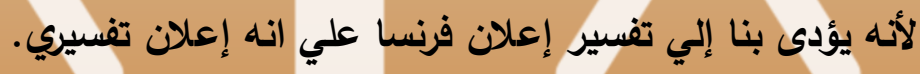
تنص المادة (6) من نفس المعاهدة علي الآي:

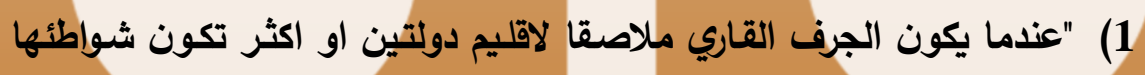

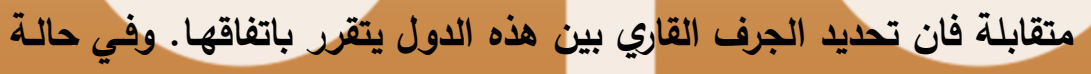

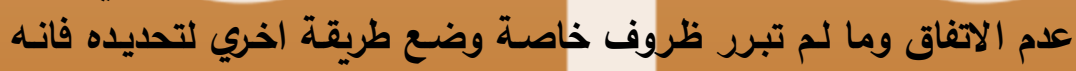

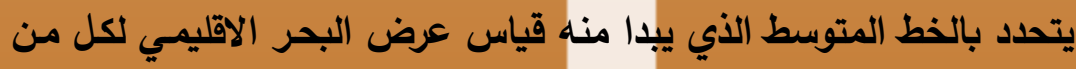

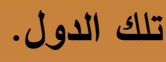

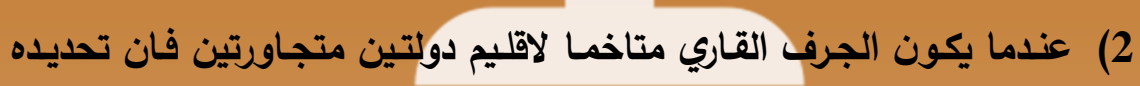

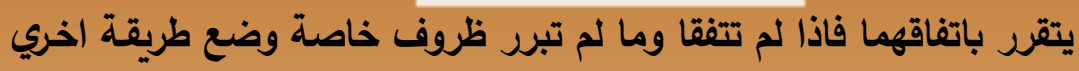

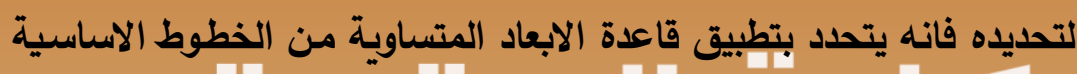

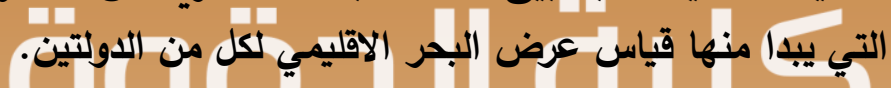

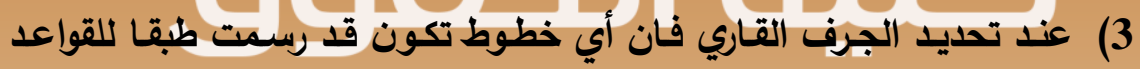

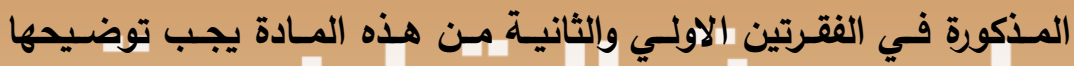

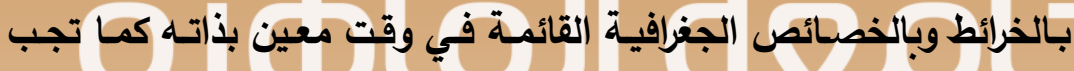
الاشارة الي النقاط الدائمة والواضحة علي الارضل

(1) United Nations Treaty Collection, http://treaties.un.org/Pages/ViewDetails.aspx?src=TREATY\&mtdsg_no $=$ XXI-4\&chapter $=21 \&$ lang $=$ en

(2) Article 6 of the Convention on the Continental Shelf states that: 


\section{وقد قامت الدول باصدار الإعلانات الاتية:}

فرنسا (1965/6/14): "في حالة عدم وجود إتفاق محدد، فإن حكومـة فرنسـا

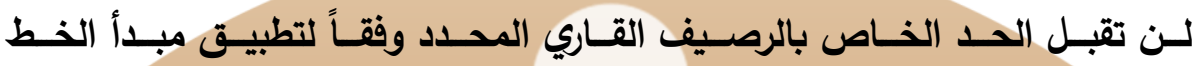
المتوسطequidistance في حالة: 1

إذا كـان تعديــ الحـد مـن خطوط الموازيـة وإلتي تـم رسـمها بعد 29 أبردية .1958

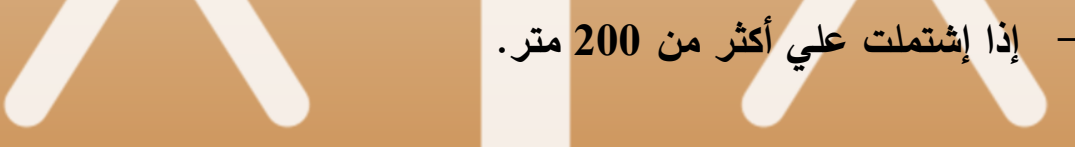

1. Where the same continental shelf is adjacent to the territories of two or more States whose coasts are opposite each other, the boundary of the continental shelf appertaining to such States shall be determined by agreement between them. In the absence of agreement, and unless another boundary line is justified by special circumstances, the boundary is the median line, every point of which is equidistant from the nearest points of the baselines from which the breadth of the territorial sea of each State is measured.

2. Where the same continental shelf is adjacent to the territories of two adjacent States, the boundary of the continental shelf shall be determined by agreement between them. In the absence of agreement, and unless another boundary line is justified by special circumstances, the boundary shall be determined by application of the principle of equidistance from the nearest points of the baselines from which the breadth of the territorial sea of each State is measured.

3. In delimiting the boundaries of the continental shelf, any lines which are drawn in accordance with the principles set out in paragraphs 1 and 2 of this article should be defined with reference to charts and geographical features as they exist at a particular date, and reference should be made to fixed permanent identifiable points on the land.

(1) United Nations Treaty Collection, http://treaties.un.org/Pages/ViewDetails.aspx?src=TREATY\&mtdsg_no =XXI-4\&chapter $=21 \&$ lang $=$ en 


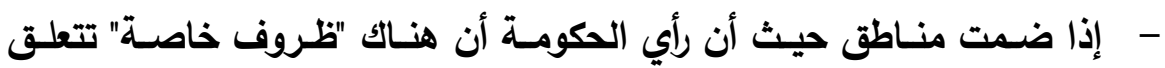

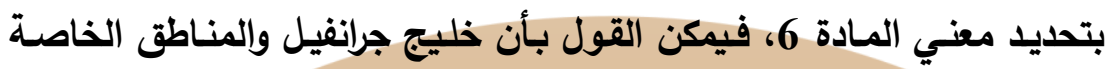
بمضايق دوفر والبحر الثمالي بجانب الساحل الفرنسي. و قد اعترضت كل من كندا، اسبانيا، تايلند والولايات المتحدة علي الاعلان

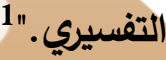
الصين 1970/10/12: "فيما يتعلق بتحديد الجزي الخاص بالرصيف القاري

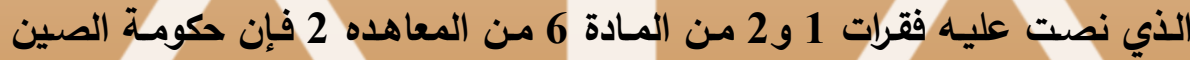

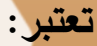

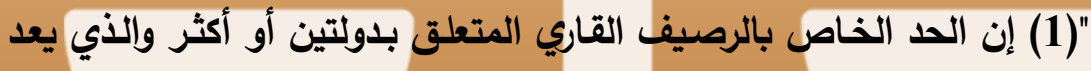

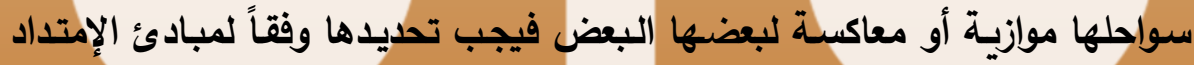

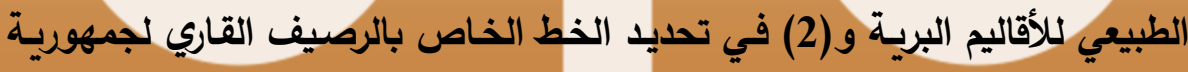
الصين فإن الصخور لا يمكن أخذها في الإعتبار.2 2

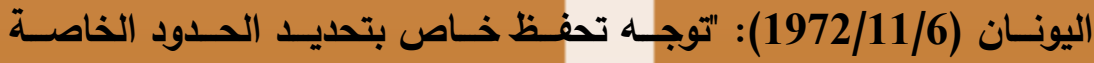

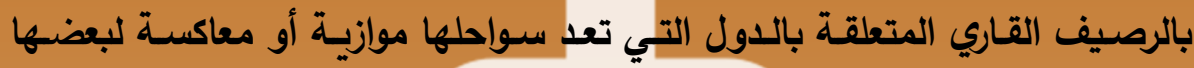

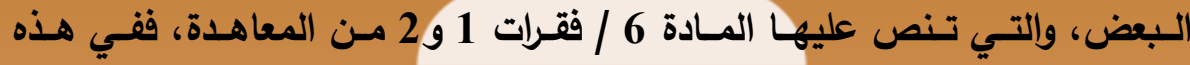

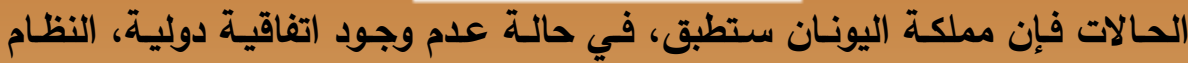

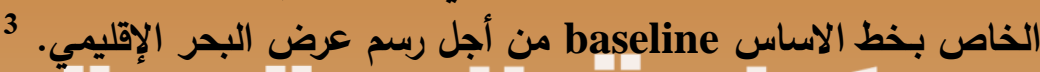

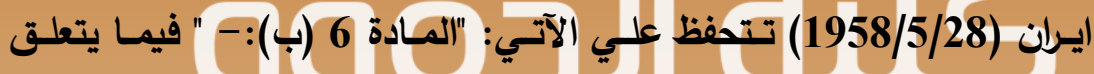

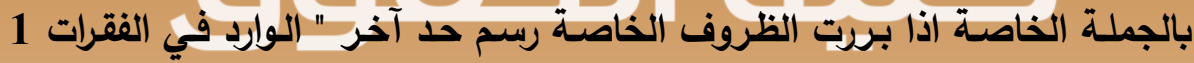

(1) United Nations Treaty Collection, http://treaties.un.org/Pages/ViewDetails.aspx?src=TREATY\&mtdsg_no =XXI-4\&chapter $=21 \&$ lang $=$ en

(2) United Nations Treaty Collection, http://treaties.un.org/Pages/ViewDetails.aspx?src=TREATY\&mtdsg no =XXI-4\&chapter=21\&lang $=$ en

(3) United Nations Treaty Collection, http://treaties.un.org/Pages/ViewDetails.aspx?src=TREATY\&mtdsg_no =XXI-4\&chapter $=21 \&$ lang $=$ en 
و2 من المـادة، فإن الحكومـة الإيرانية تقبل هذه الحيلة بناء علي فهمها الخاص بأن طريقة واحدة لتحديد الخط في ظروف خاصة هو من عند نقطة البحر العالى. 1

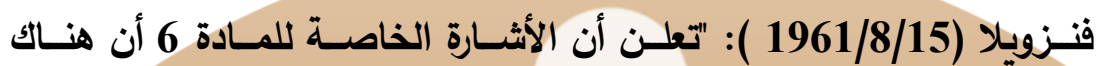

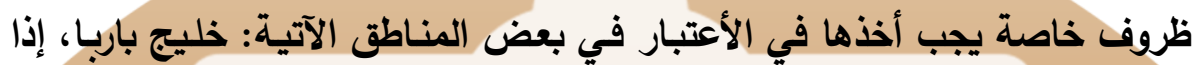

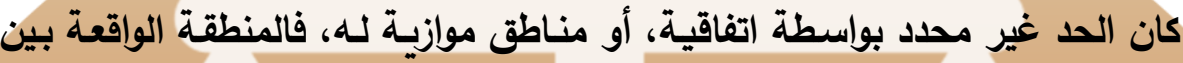
ساحل فنزويلا وجزيرة اروبا وخليج فنزويلا". 2 يوجوسـلافيا (1966/1/28): "في تمديــ الرصيف القـاري فـان يوجوسـلافيا

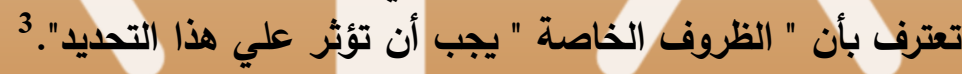

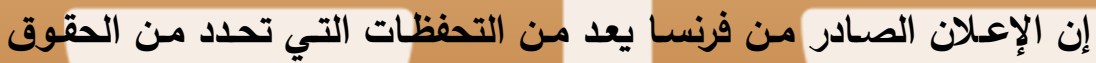

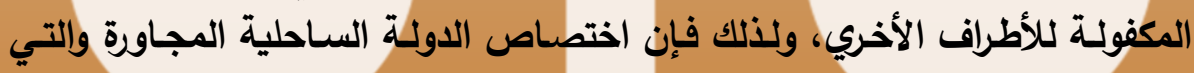

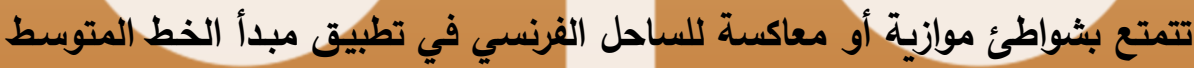
equidistance ساريا نظراً لأن التحفظ الفرنسي تم قبوله وأصبح سارياً.

إن الأعلان الفرنسي يشـل عدة أجزاء، وكـلاً منها يجب تمليلـه: إن فرنسـا

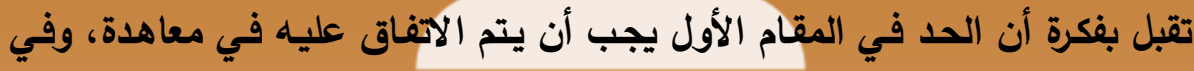

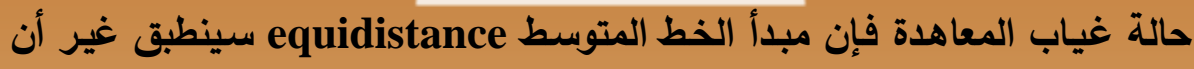

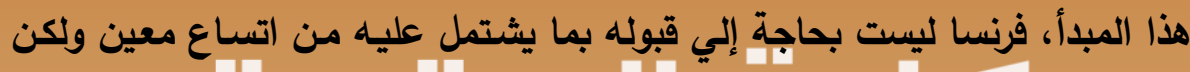

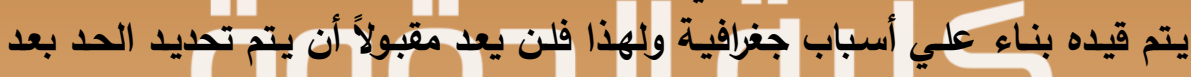

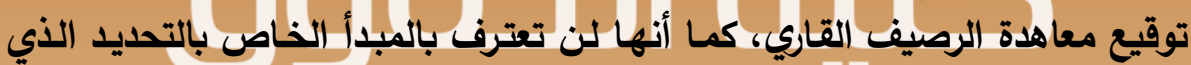

(1)

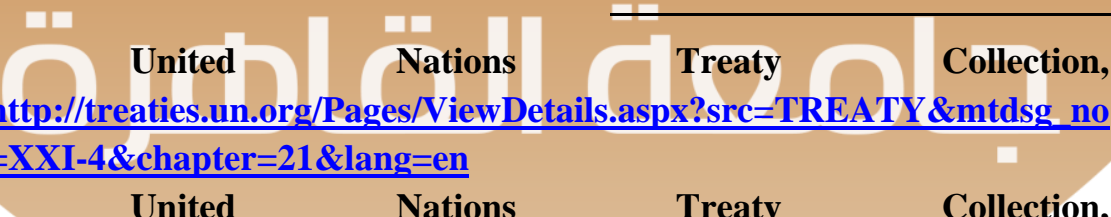

(2) United Nations Treaty Collection, http://treaties.un.org/Pages/ViewDetails.aspx?src=TREATY\&mtdsg_no $=$ XXI-4\&chapter $=21$ \&lang $=$ en

(3) United Nations Treaty

Collection, http://treaties.un.org/Pages/ViewDetails.aspx?src=TREATY\&mtdsg_no =XXI-4\&chapter $=21 \&$ lang $=$ en 


$$
\text { يشتمل علي أكثر من } 200 \text { متر في العمق. }
$$

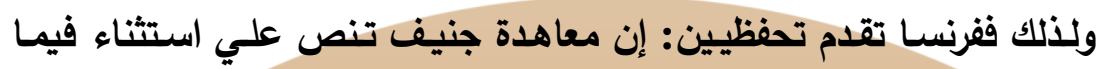

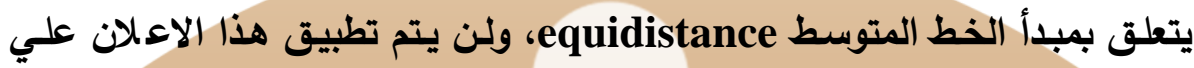

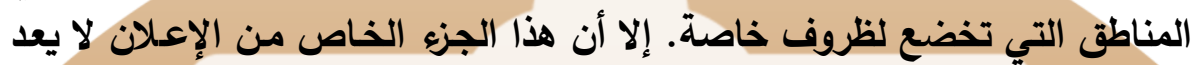

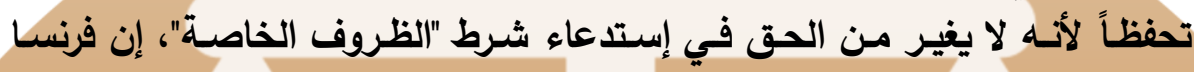
تحدد فقط الظروف التي تراها مناسبة لتشكيل ظروف خاصة.

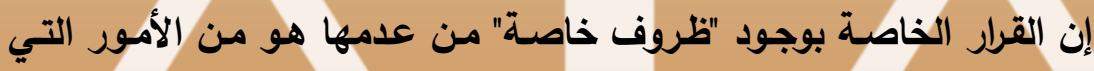

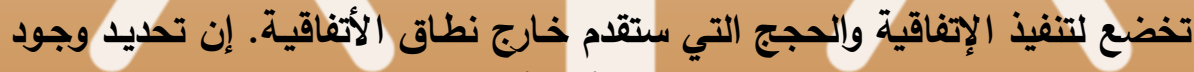

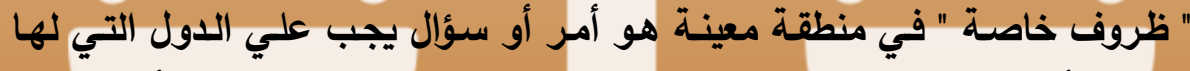

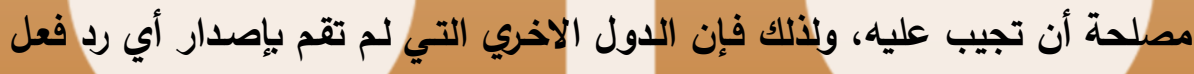

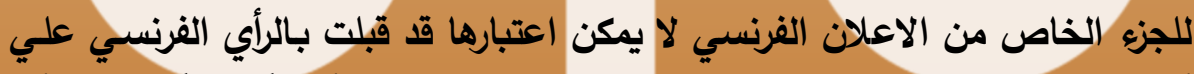

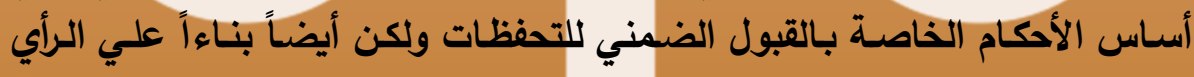

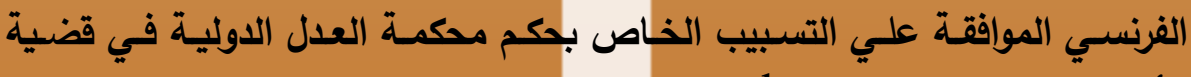

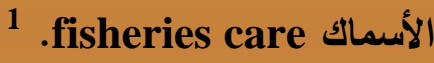

يع الأعلان الفرنسي تحفظاً إذا كان الأعلان الخاص بالتففير أو بمعني أصح

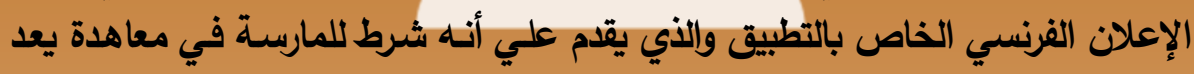

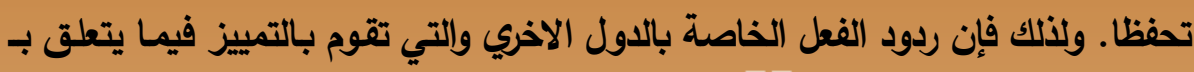

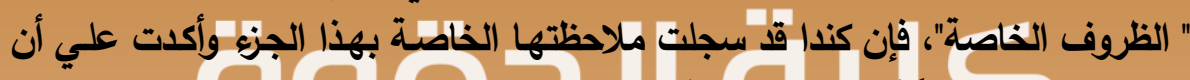

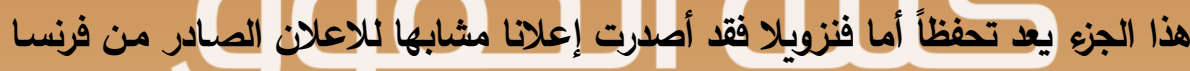

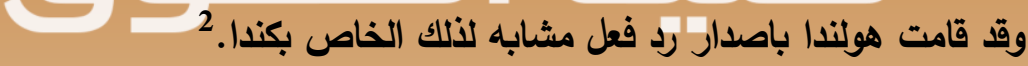

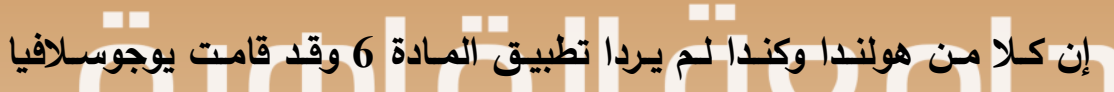
بالتعليق علي البند الخاص "ظروف خاصة " وقامت بإصدار إعلان خاص بأنسه

(1) International Court of Justice, http://www.icjcij.org/docket/files/5/1811.pdf

(2) United Nations Treaty Collection, http://treaties.un.org/Pages/ViewDetails.aspx?src=TREATY\&mtdsg_no =XXI-4\&chapter $=21 \&$ lang $=$ en 
ليس هناك ظروف خاصـة فيما يتعلق بالبحر الأدريـاتيكي وذلك فيما يتعلق بتحديد

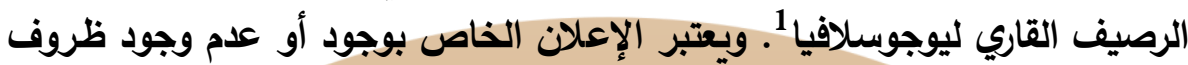

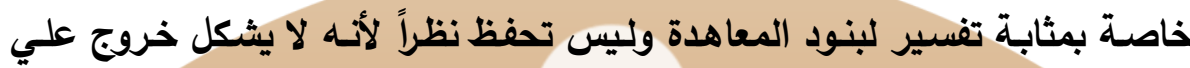
القواعد الوارده في المعاهدة.

\section{(11) هماهدة الأهم المتمدة الخاصة بقانون البمار (1982/12/10)}

الاعـلان الصـادر مـن الـيمن (1982/12/10): "3- تؤكـــ الـيمن سـيادتها

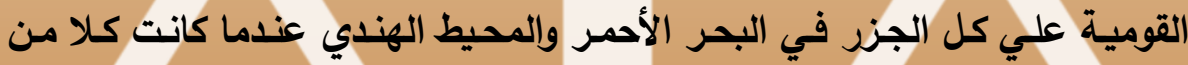

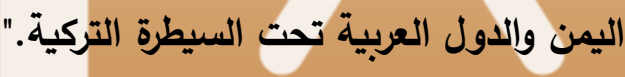

رد فعل أثيوبيا (1984/11/8): "إن الفقرة 3 من الاعلان الصادر من اليمن

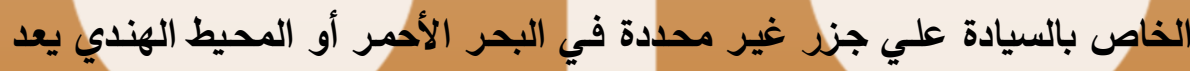

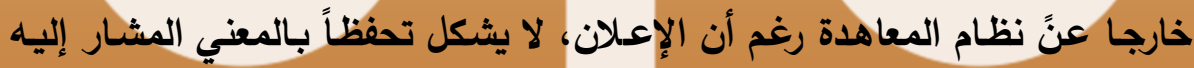

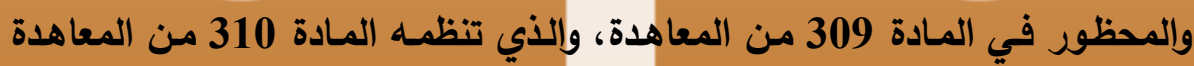

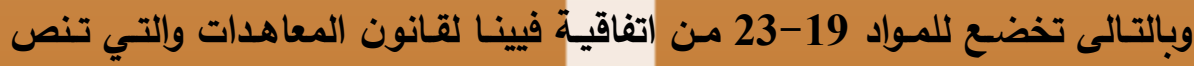

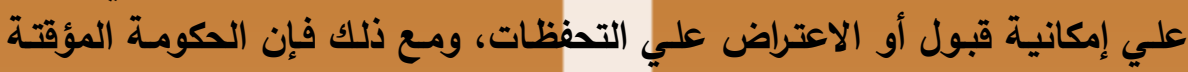

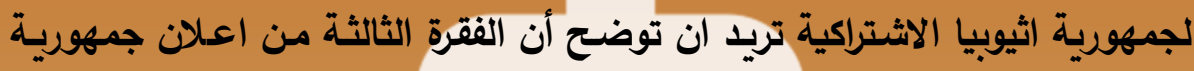

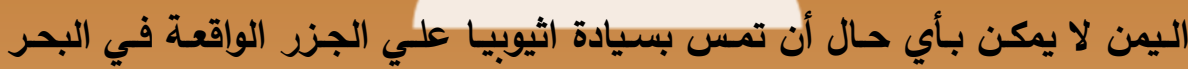

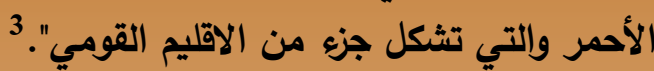

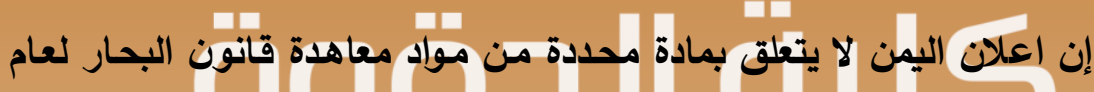

(1) United Nations Treaty Collection, http://treaties.un.org/Pages/ViewDetails.aspx?src=TREATY\&mtdsg_no =XXI-4\&chapter $=21$ \&lang=en

(2) United Nations Convention on the law of the Sea. United Nations Treaty Collection, http://treaties.un.org/Pages/ViewDetailsIII.aspx?\&src=TREATY\&mtds g_no=XXI 6\&chapter $=21 \&$ Temp=mtdsg3\&lang=en

(3) United Nations Treaty Collection, http://treaties.un.org/Pages/ViewDetailsIII.aspx?\&src=TREATY\&mtds g no $=$ XXI $\sim$ 6\&chapter $=21 \&$ Temp $=$ mtdsg3\&lang $=$ en 


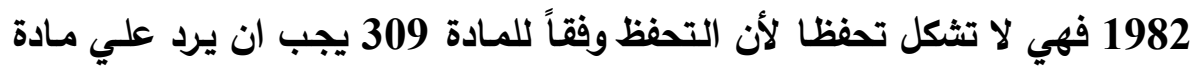

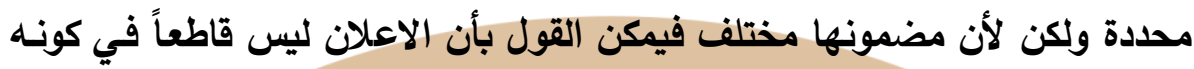

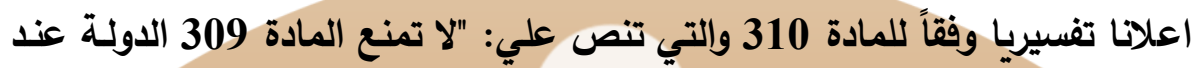

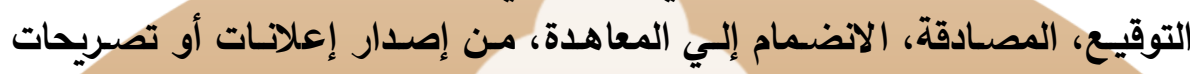

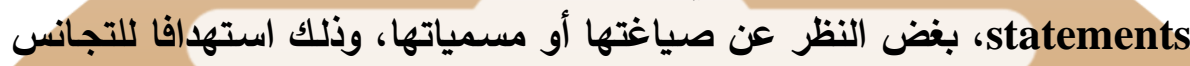

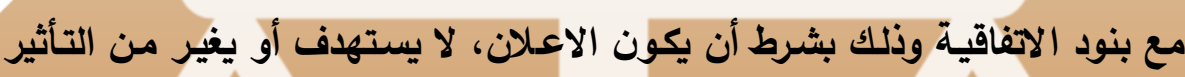

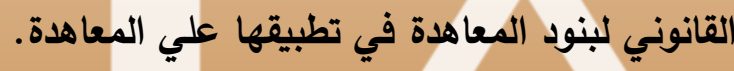

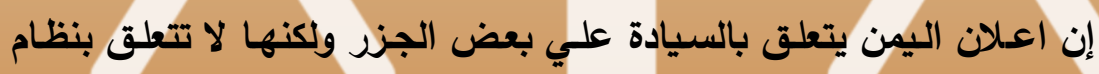

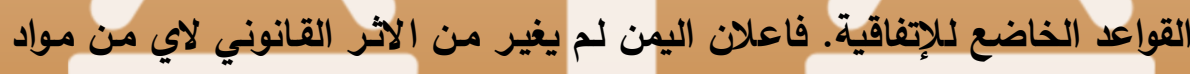

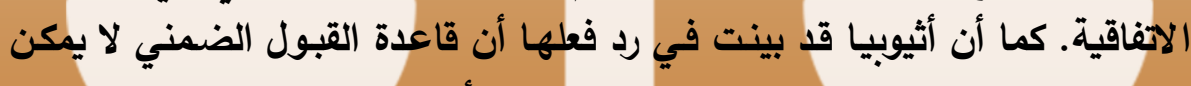

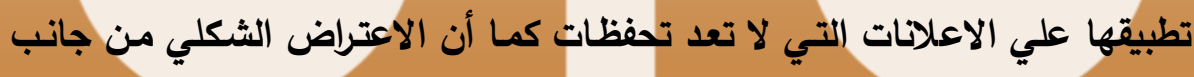

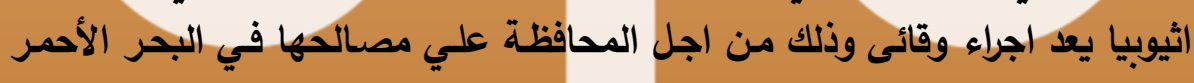

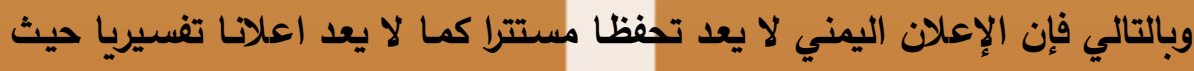

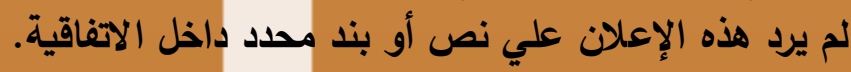

$$
\begin{aligned}
& \text { (12) الثفاقية فيينا (قانمو المعاهد/ت) 1969/5/23: } \\
& \text { تنص المادة } 7 \text { (2) من قانون المعاهدات علي الاتي: }
\end{aligned}
$$

إن الدولة عند ممارستها لوظائفها فإن الآتي ذكرهم يمثل الدولة:

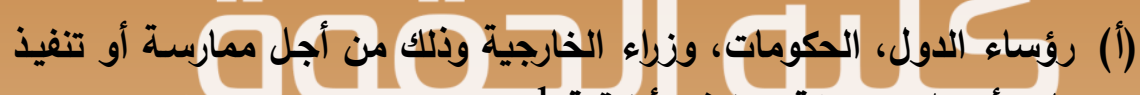
كل الأعمال المتعلقة بتنفيذ الأففاقية.

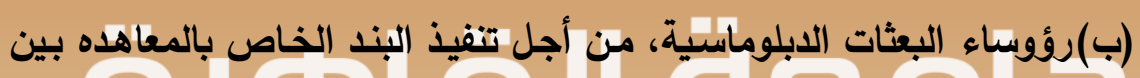

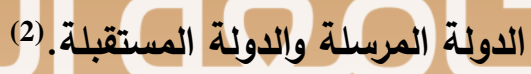

(1) Art. 7 (7) of Vienna Convenion on the law of treaties. United Nations Treaty Collection, http://treaties.un.org/Pages/ViewDetailsIII.aspx?\&src=TREATY\&mtds g no=XXIII 1 \&chapter $=23 \&$ Temp=mtdsg $3 \&$ lang=en

(2) Art. 7 (7) of Vienna Convenion on the law of treaties. United Nations Treaty

Collection, 


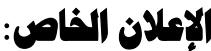

فنلندا (1977/8/19):" تعلن فنلندا أنـه لا يوجد أى شئ في الفقرة (2) من

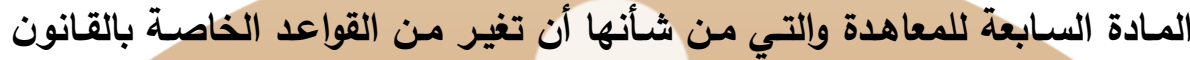

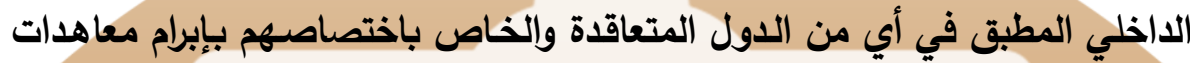

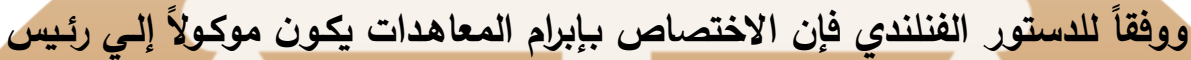

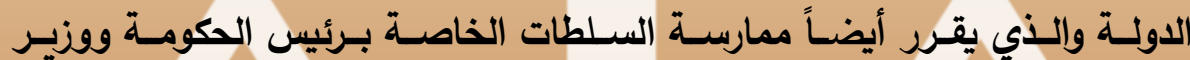

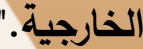
رد فعل المملكة المتحدة (1977/12/7): "لا يعـ الاعـلان بـاي حـال غير تفسير أو تطبيق المادة 7 من المعاهدة." المدلة المدة (12/7

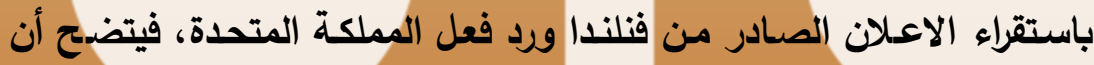

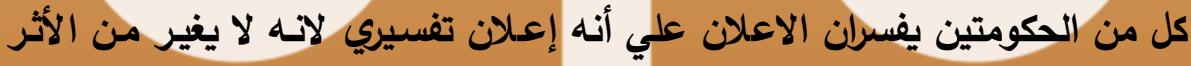

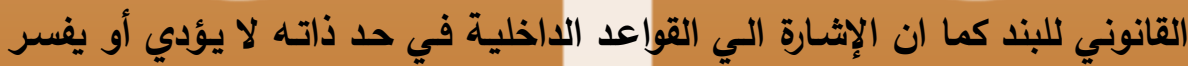

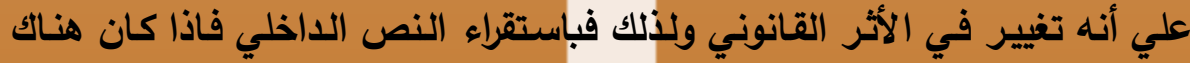

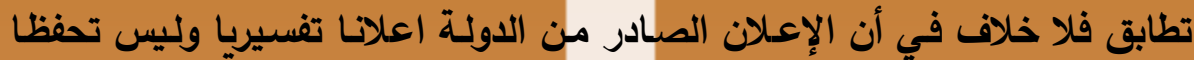

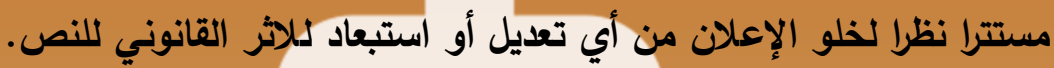
وقد أعلت المملكة المتحدة أن التفسير الفنلندي ينطوي علي لأيها الخاص2 2

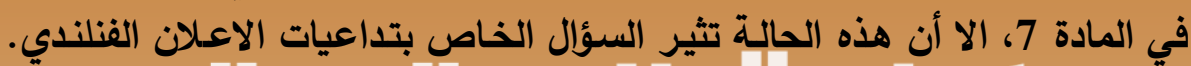

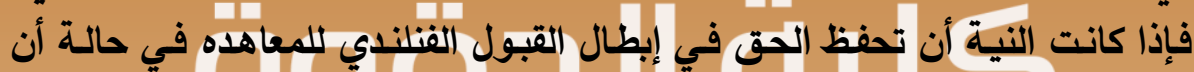
وزير الخارجية علي سبيل المثال قد قام بعدة أعمال تعد من إختصاص وسلطات

http://treaties.un.org/Pages/ViewDetailsIII.aspx?\&src=TREATY\&mtds g_no=XXIII 1 \&chapter $=23 \&$ Temp $=$ mtdsg $3 \&$ lang $=$ en

(1) United Nations Treaty Collection, http://treaties.un.org/Pages/ViewDetailsIII.aspx?\&src=TREATY\&mtds g_no=XXIII 1 \& chapter $=23 \&$ Temp $=$ mtdsg3\&lang=en

(2) United Nations Treaty Collection, http://treaties.un.org/Pages/ViewDetailsIII.aspx?\&src=TREATY\&mtds g_no=XXIII $\sim$ \&chapter $=23 \&$ Temp $=$ mtdsg 3\&lang=en 
الرئيس فهل يعد هذا الاعلان تحفظاً؟ 1

تثير مذكرة العمل التحضيري لاتفاقية فيينا إلي أن المـادة (7) (2) تستهدف

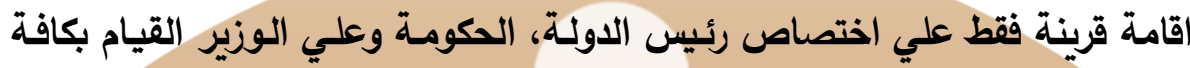

الأعمال الخاصة بإبرام المعاهدة.

ولذلك فإن أي دولـة تربـا أن تبدي هذا التحفظ عليها أن تبحث اثبات ذلك الك الكيات

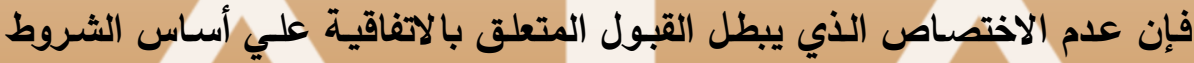

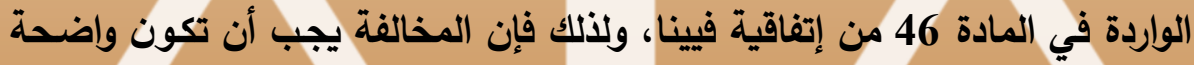

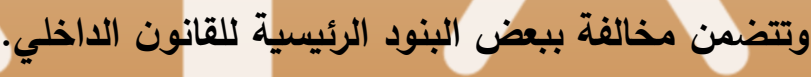

و إذا كان لا يشترط أن تكون هناك اتفاقيات بين دول الثـمال لها صـلاحيات

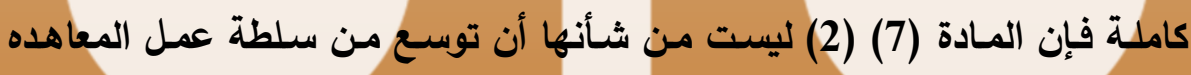

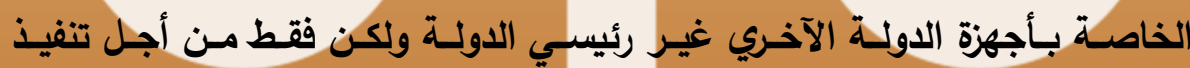

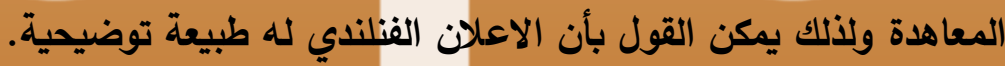
تنص المادة 52 من اتفاقية فيينا علي الاتي: لهي: "تعد المعاهده باطلة اذاكان تنفيذها قد تم عن طريق التهايد او إستخدام

القوة بالمخالفة لمبادئ قانون الدولة المتضمنة في وثيقة الأمم المتحدة". 3

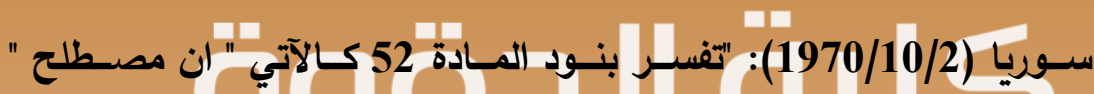

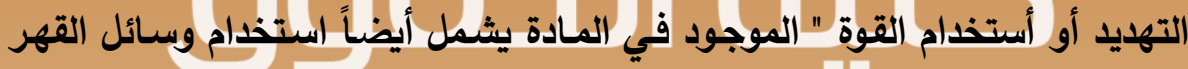

(1) United Nations http://treaties.un.org/Pages/ViewDetailsIII.aspx?\&src=TREATY\&mtds g_no=XXIII $\sim$ \&chapter $=23 \&$ Temp $=$ mtdsg 3\&lang=en

(2) Frank Horn, Reservations and interpretative declarations to multilateral treaties, op. cit.; $p$.

(3) Art. 2 of Vienna Convenion on the law of treaties. United Nations Treaty Collection, http://treaties.un.org/Pages/ViewDetailsIII.aspx?\&src=TREATY\&mtds g_no=XXIII $1 \&$ chapter $=23 \&$ Temp=mtdsg3\&lang=en $\mathrm{s}$ 
الاقتصادي، السياسي، العسكري والنفسي وكذلك كافة أعمال القهر التي من شـأنها أن تحدد وتقيد الدولة من ابرام معاهدة في صالحها". 1 رد فمل من الدول الآتية:

اليابان 1981/7/2: "لا تقبل تفسير المـادة 52 بهذا الشكل، حيث أن هذا

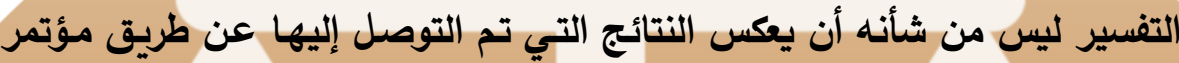
فيينا في المادة المتعلقة بالقهر ". 2

السويد (1975/2/4): "بمـا أن المـادة 52 تشـير إلـي التهديـاد او أسـتخدام

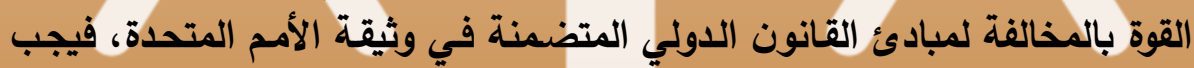
تفسيرها في ضوء ممارسات الدول التي تم تطويرها أو سيتم علي أساس الوثيقة ". المملكة المتحدة ( 1971/6/25): "لا تقبل التفسير الذي لا يعكس بطريقة

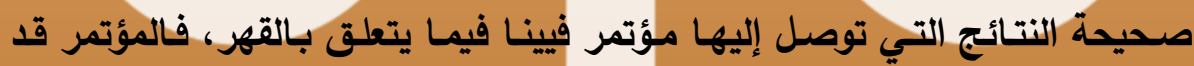

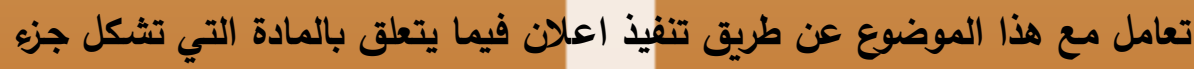

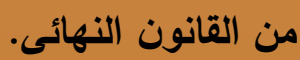

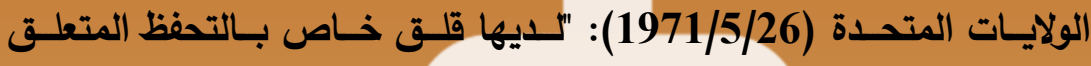

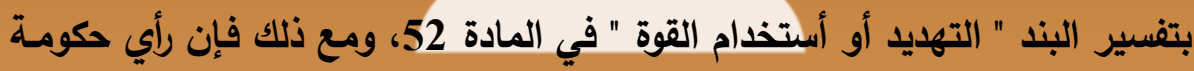

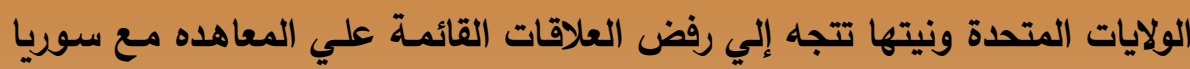

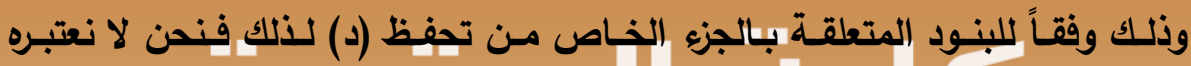
ضرورياً في هذا الوقت للأعتراض بشكل رسمي علي بلي هذه التحفظات. إن الاعلان الصـادر مـن سوريا يجب أن يفسر في ضوه المناقثـات التي

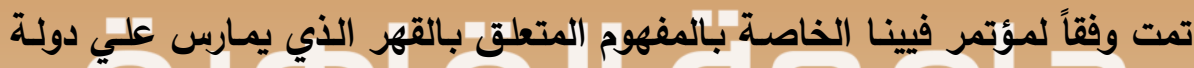

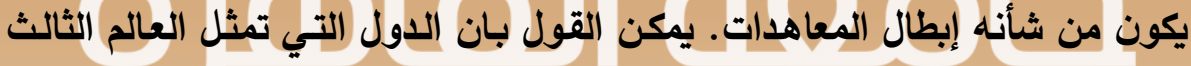

(1) United Nations Treaty Collection, http://treaties.un.org/Pages/ViewDetailsIII.aspx?\&src=TREATY\&mtds g_no=XXIII $\sim$ \&chapter $=23 \&$ Temp=mtdsg3\&lang=en

(2)

United Nations Treaty Collection,
http://treaties.un.org/Pages/ViewDetailsIII.aspx?\&src=TREATY\&mtds g_no=XXIII $1 \&$ chapter $=23 \&$ Temp=mtdsg3\&lang=en 


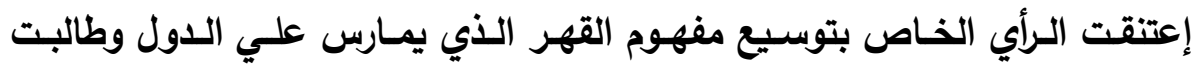

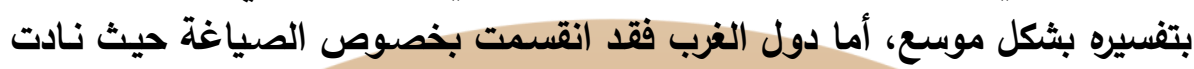

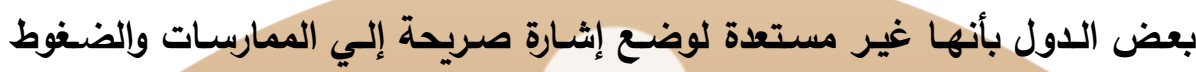

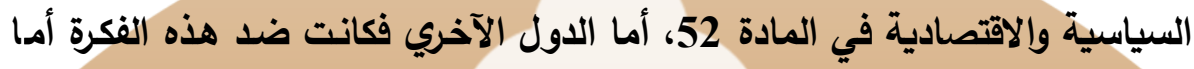

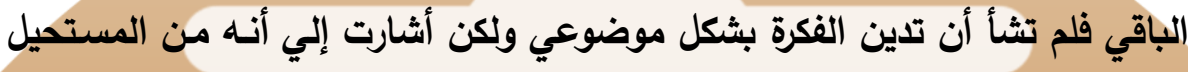
الوصول الي صياغة واضحة في هذه المرحلة.

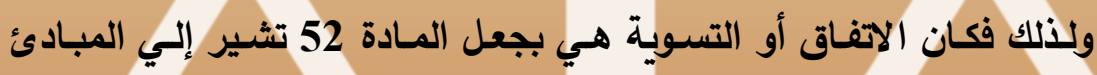

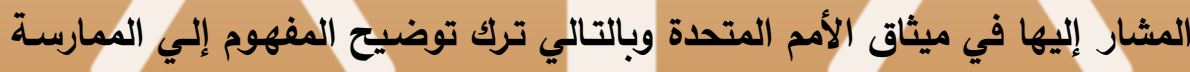

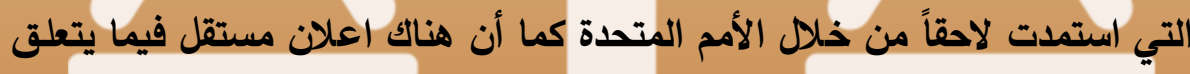

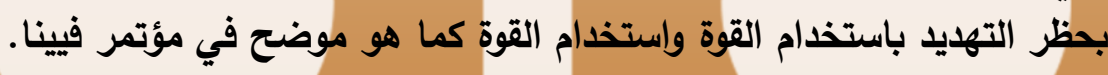

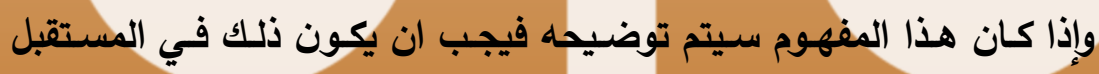

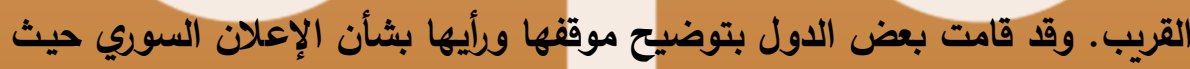
أكلات علي أن ذلك الاعلان الصادر من سوريا يعد فهما انفراديا للمادة 52.

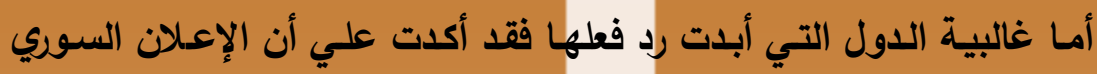

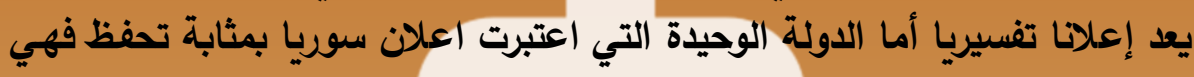

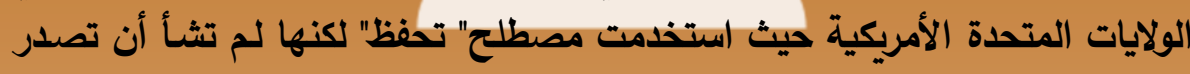

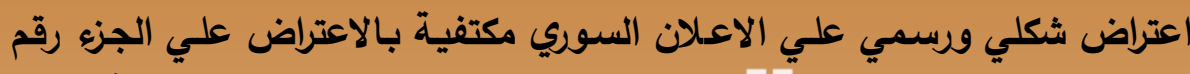

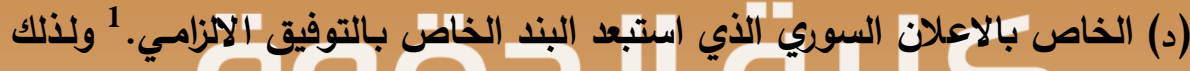

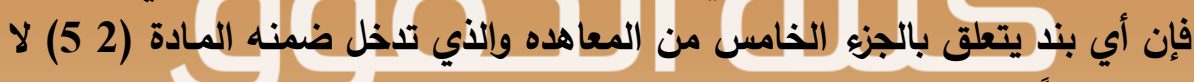
يعد منطبقاً بين الولايات المتحدة وسوريا. ويمكن القول أن الولايات المتحدة تعتبر هذا الإعلان الصسادر من سوريا.

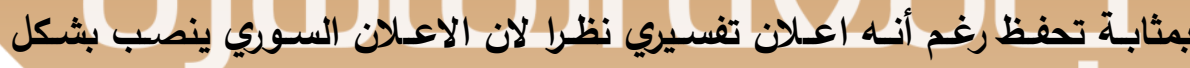

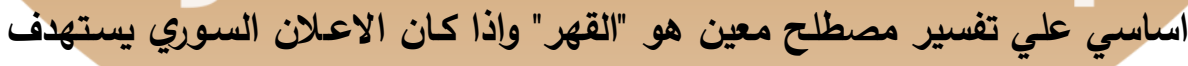

(1) United

Nations

Treaty

Collection,

http://treaties.un.org/Pages/ViewDetailsIII.aspx?\&src=TREATY\&mtds g_no=XXIII $\sim$ \&chapter $=23 \&$ Temp $=$ mtdsg3\&lang $=$ en 
توسيع هذا المفهوم الا انه لا يثكل تغييرا للاثر القانوني للمادة.

وبإستقراء الاعلانات التي تم طرحها فيما سبق وردود الفعل التي اثارها هذه

الاعلانات يمكن القول بأن الدول تجد صعوبة في تحديد طبيعة هذه الإعلانات واذاذا

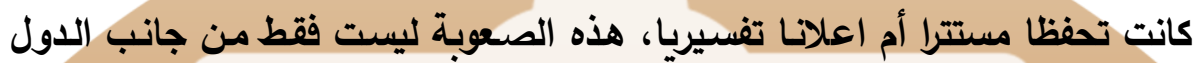
المعلنة بل أيضاً تجدها في الدول التي تظهر رد فعلها علي هذهان اعلي الاعلانات. والممارسة العملية لا تعطينا أي أثارة حول وجود قاعدة من قواعد القانون الاولي العرفي فيما يتعق بقبول أو عدم قبول الإعلان التفسيري. ويمكن تلخيص مواقف الدول بصدد الإعلانـات إلى ثلاثة مواقف رئيسية تتبناها الدول فيما يتعلق برد فعهم ازاء الاعلانات الصادرة من الدول الآخري: فإذا قامت دولة ما بتحليل الاعلان الصادر من دولة اخري، فقد تتتهي إلي أمر من ثلاثة: 1- أن الاعـلان الصـادر من الدولـة هو تحفظ مستتر وليس اعلان تفسيري

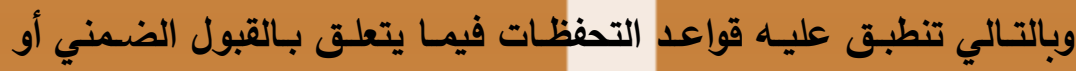
قواعد الاعتراض على التحفظات. 1

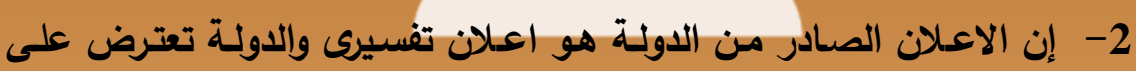

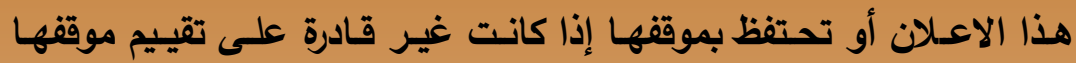
بثأن التفسير الخاص والصحيح بشأن المعاهدة.

3- أنه ليس هناك موقف محدد بشـأن الاعلان وما إذا كان اعلان تفسيري أم

تحفظ وفي هذه الحالة فإن سكوت الدولة لا يعد قبولاً ضمنياً. للذلك فالخلاصـة أن ردود فعل الـدول المختلفـة تجـاه الاعلانـات التفسيرية

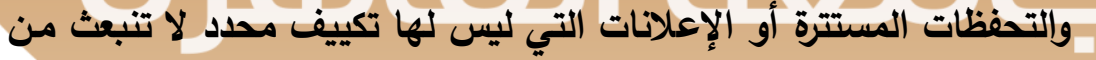

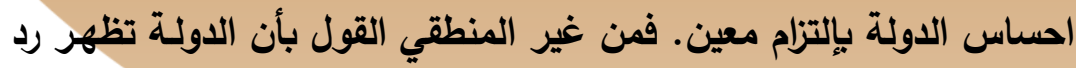

(1) United

Nations

Treaty

Collection,

http://treaties.un.org/Pages/ViewDetailsIII.aspx?\&src=TREATY\&mtds g_no=XXIII $\sim$ 1\&chapter $=23 \&$ Temp $=$ mtdsg3\&lang $=$ en 
فعلها تجـاه الاعلانـات التفسيرية على أسـاس إلتزام قـانوني بحجـة أن الغالبية العظمي من الدول تقوم بذلك.

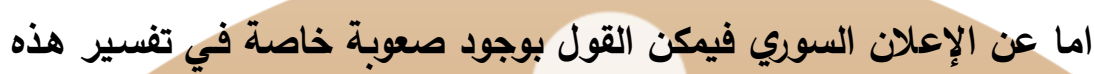

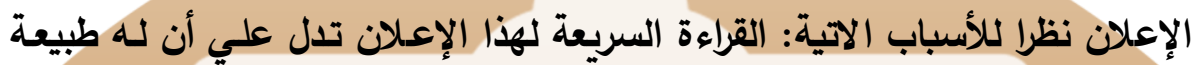

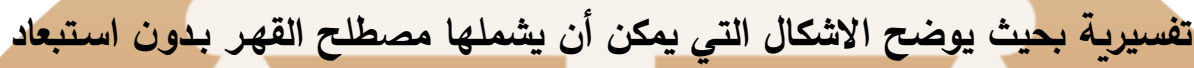

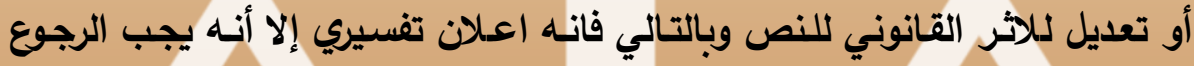

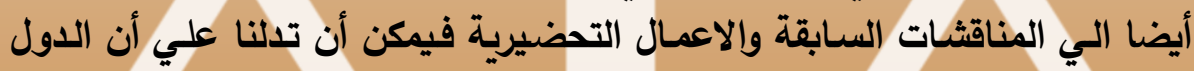

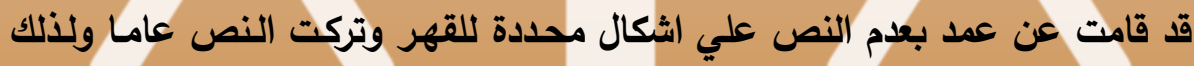

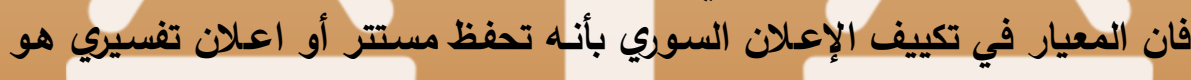

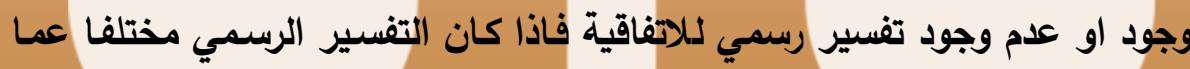

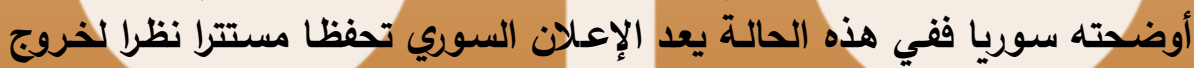

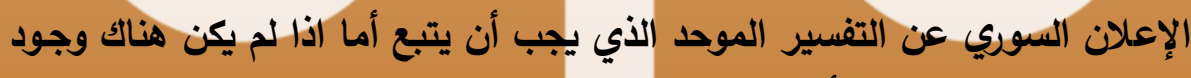

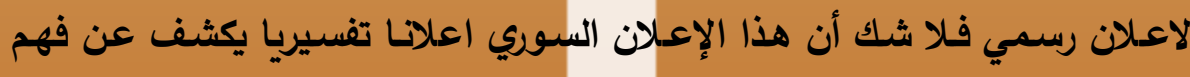
سوريا للنص المشار اليه.

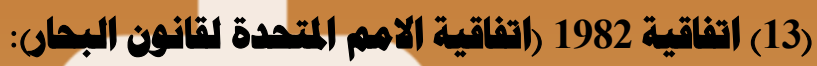

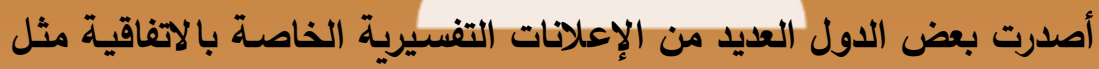

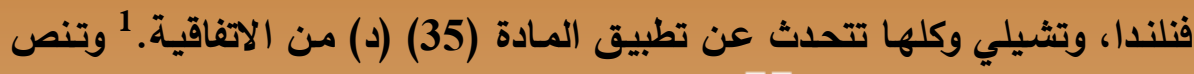

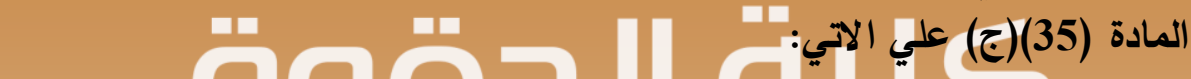

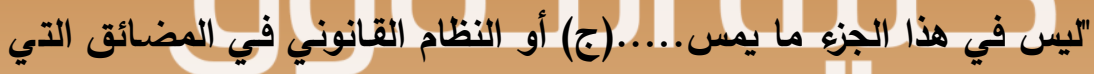

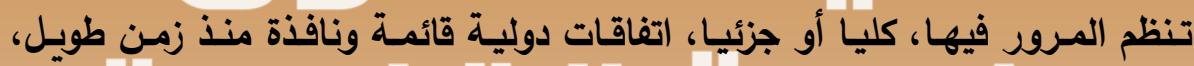

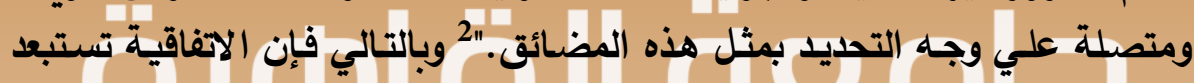

(1) United Nations Treaty Collection , http://treaties.un.org/Pages/ViewDetailsIII.aspx?\&src=TREATY\&mtds g_no=XXI 6\&chapter=21\&Temp=mtdsg3\&lang=en

(2) United Nations Treaty Collection , http://treaties.un.org/Pages/ViewDetailsIII.aspx?\&src=TREATY\&mtds g_no=XXI $\sim 6 \&$ chapter $=21 \&$ Temp $=$ mtdsg $3 \&$ lang $=$ en 
المضايق المستخدمة للملاحة الدولية التي ينظم المرور فيها اتفاقات خاصـة قائمـة ونافذة منذ زمن طويل، الذي وضعته الاتفاقية. وقد قامت فنلندا بإصدار الإعلان الاتي عند توقيعها على الاتفاقية:

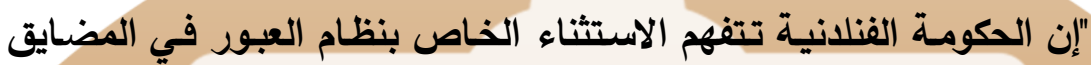

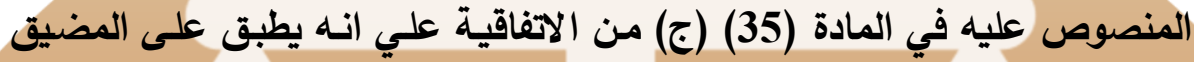

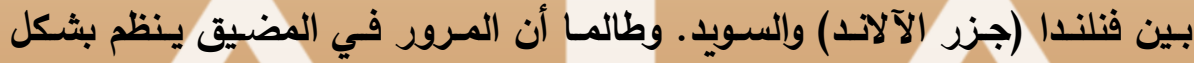

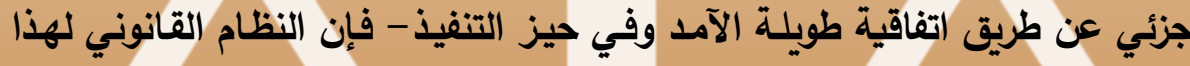
المضيق لن يخضع لأي تغيير حتى بعد دخول المعاهدة حيز التنفيذ". 1

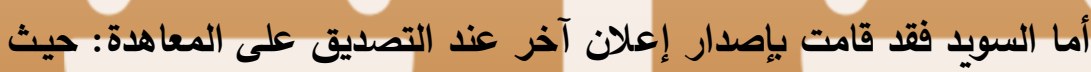

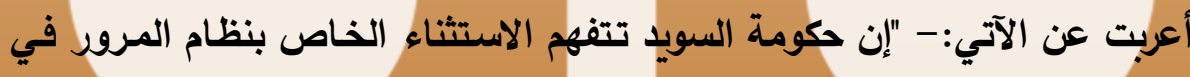

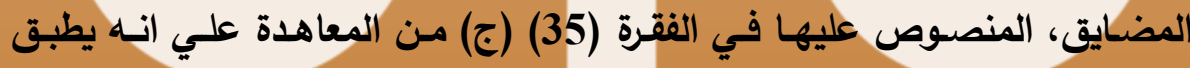

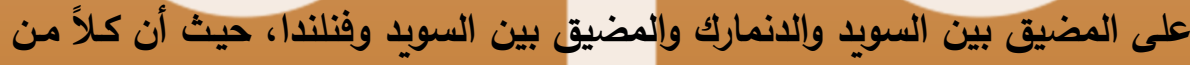

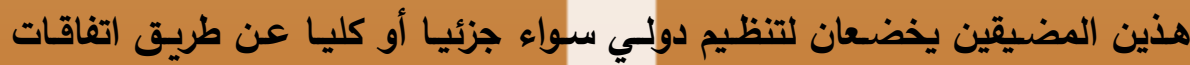

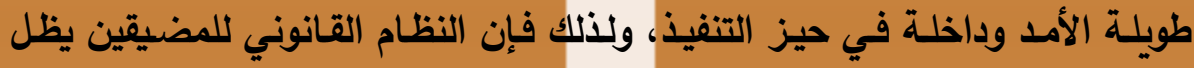
بدون تغيير".

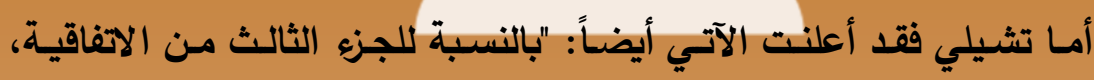

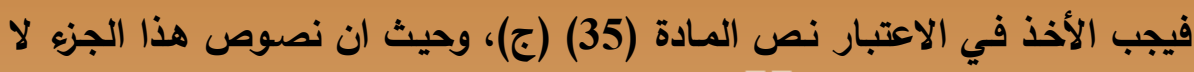

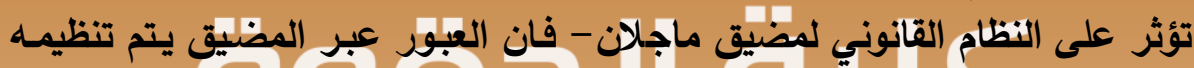

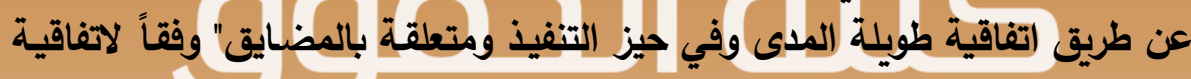

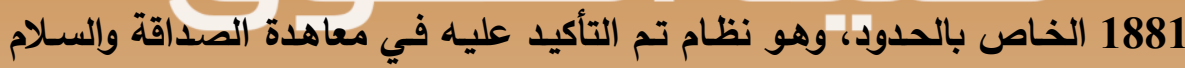

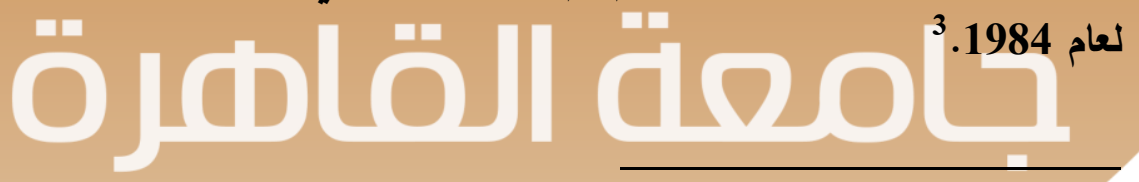

(1) Multilateral treaties deposited with the Secretary General (ST/LEG/SER.E/17).

(2) Loc. Cit.

(3) United Nations Treaty Collection http://treaties.un.org/Pages/ViewDetailsIII.aspx?\&src=TREATY\&mtds g_no=XXI $\sim 6 \&$ chapter $=21 \&$ Temp $=$ mtdsg $3 \&$ lang $=$ en 


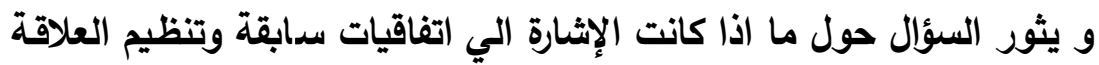

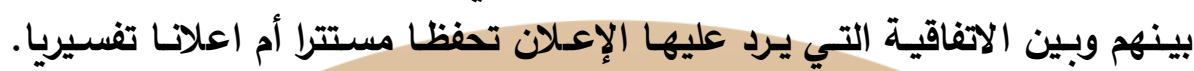

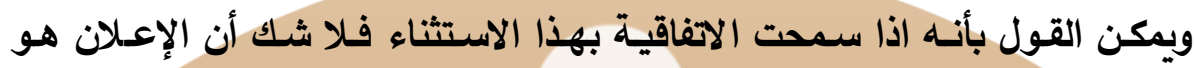

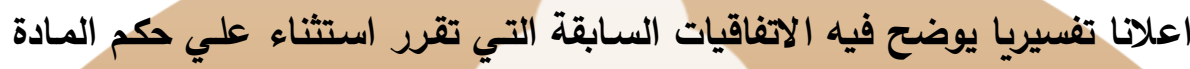

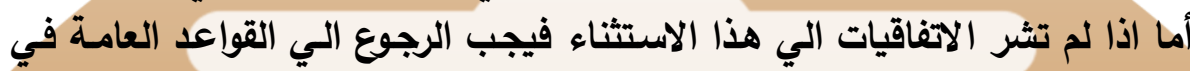

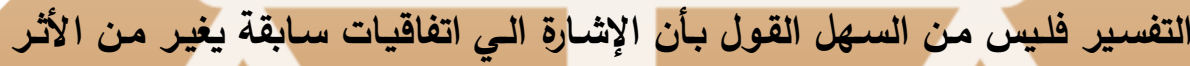

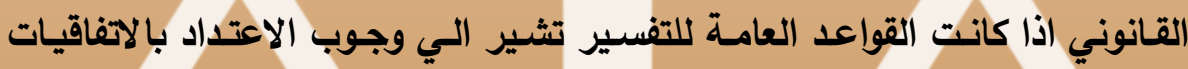
السابقة الا أن القاعدة الاصيلة هي اللاحق ينسخ السابق.

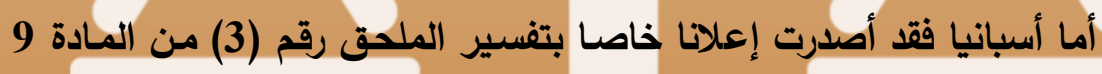
للمعاهدة على النحو التالي: المبان

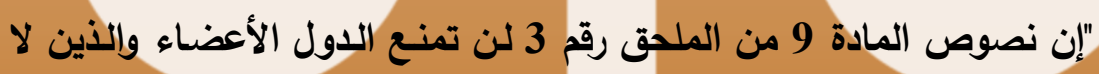

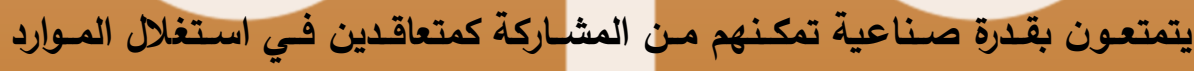

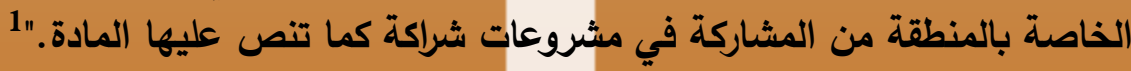

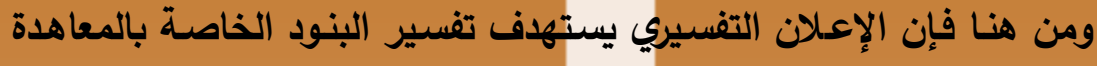

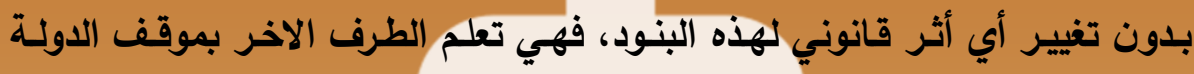

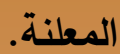

واتفاقيـة 1982 للبحسار لا تظلو مـن بعض الكلمـات التي تثير لبسـاً حول

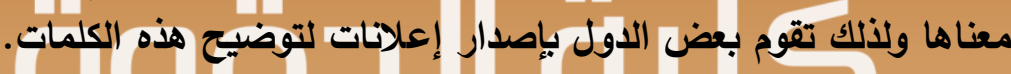

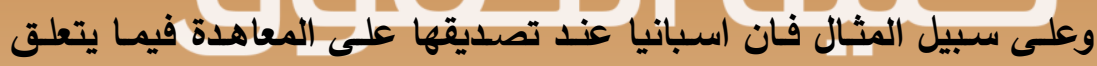
بالمادة (39) (فقرة) (3)(أ) ذكرت:

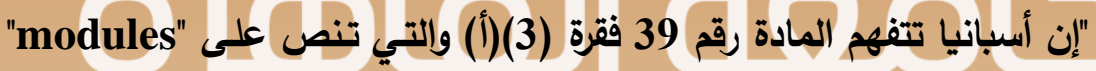
http://treaties.un.org/Pages/ViewDetailsIII.aspx?\&src=TREATY\&mtds g_no=XXI $\sim 6 \&$ chapter $=21 \&$ Temp $=$ mtdsg $3 \&$ lang $=$ en 


$$
\text { بطبيعة الحال على أنها "غير حالات القوة القاهرة والقهر". } 1
$$

أمـا فيمـا يتعلق بالسؤال الخـاص بـالحقوق الخاصـة بالدول التـي تقـع على الخـ

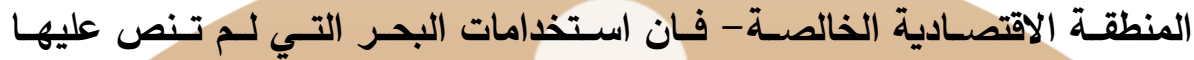

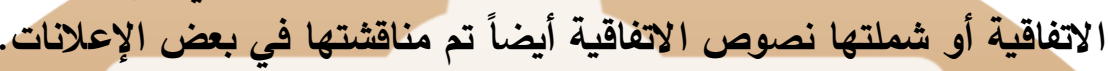
فعلى سبيل المثال، قامت أوروجواي باصدار الإعلان التفسيري الآتي: "(د)

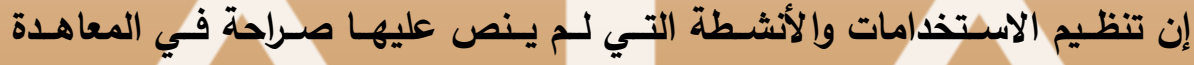

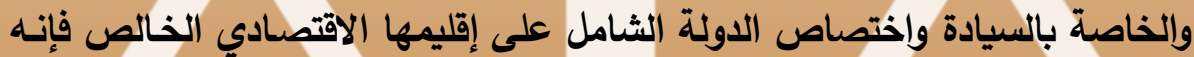

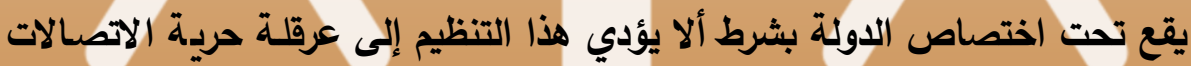
الدولية المعترف بها عن طريق جميع الدول.

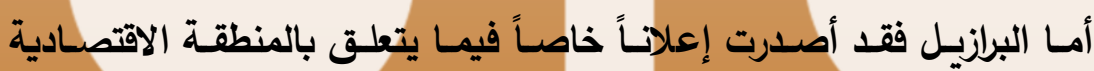

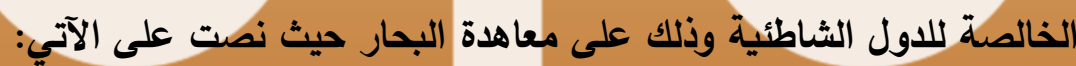
"إن الصكومة البرازيلية تفهم بنود المعاهدة على أنها لا تسمح للدول الاخري

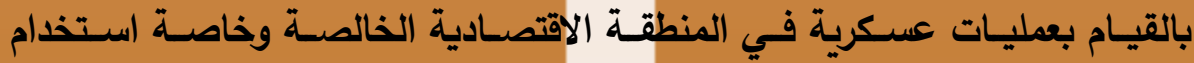
الأسلحة أو المتفجرات بدون موافقة الدول الثاطئية."3

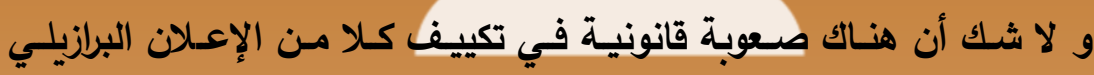

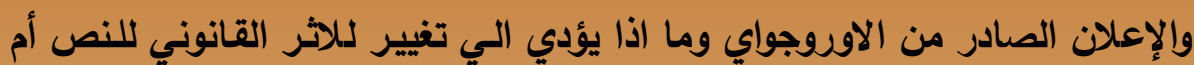

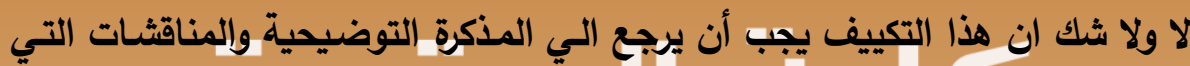

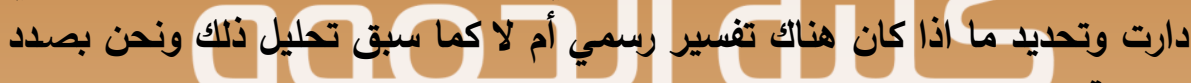
مناقشة الإعلان السوري.

(1)
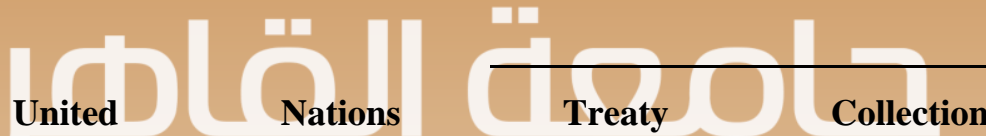
http://treaties.un.org/Pages/ViewDetailsIII.aspx?\&src=TREATY\&mtds g no=XXI 6\&chapter $=21 \&$ Temp $=$ mtdsg3\&lang $=$ en

(2) Multilateral treaties deposited with the Secretary General (ST/LEG/SER.E/17).

(3) United Nations Collection, http://treaties.un.org/Pages/ViewDetails.aspx?src=TREATY\&mtdsg_no $=$ =III-3\&chapter $=3 \&$ lang $=$ en 


\section{(14) اثفاقية العلاقات والمصانات الدبلوماسية (فيينا 18 (أبريل 1961)}

و نسـعرض هنـا الاعـلان الصـادر مـن الحكومـة السـودانية وتعليق ألمانيـا

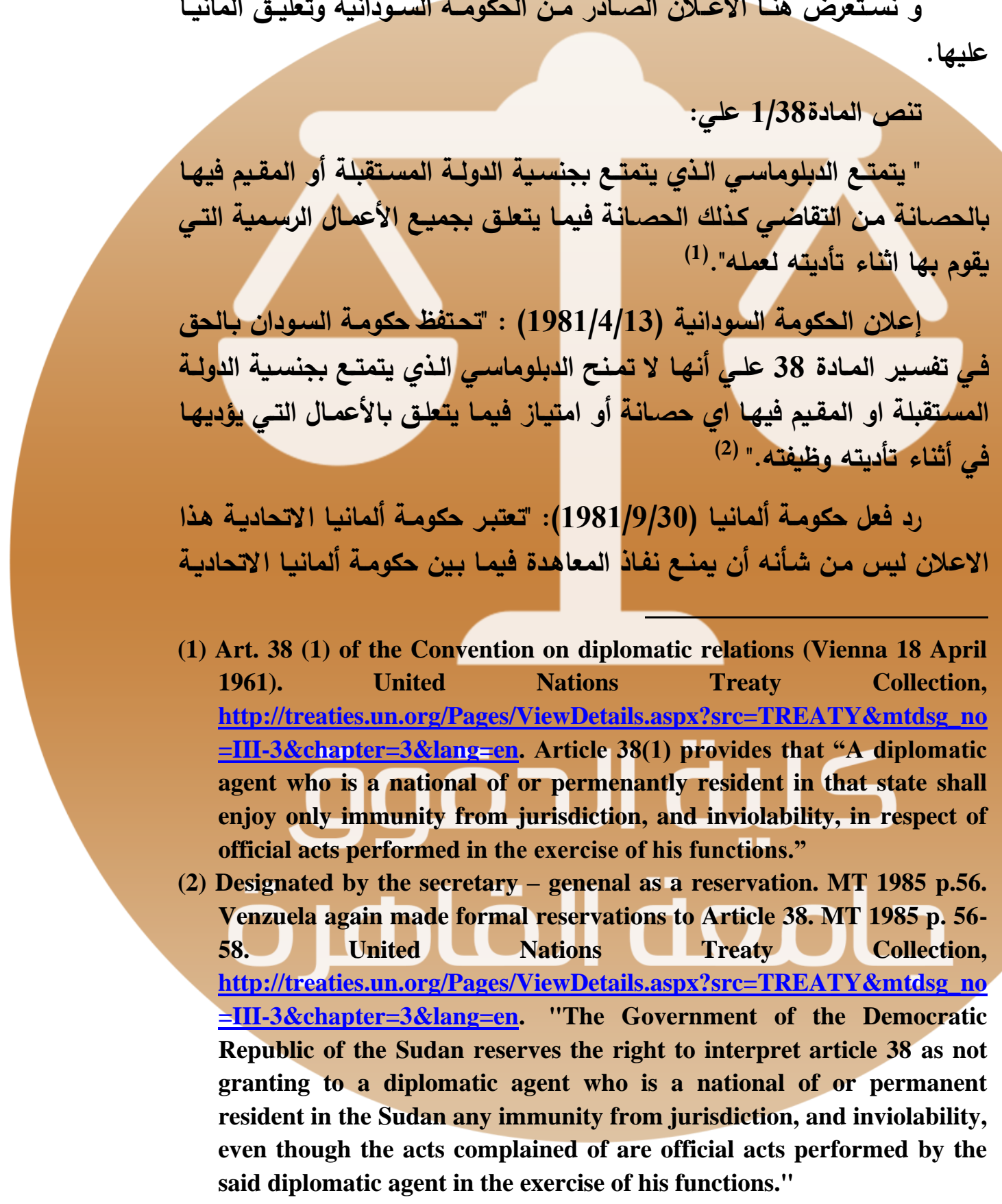


وجمهورية السودان".(1)

إن الاعلان الصـادر مـن المكومـة السودانية يُعد تحفظاً مستترا علي الرغم

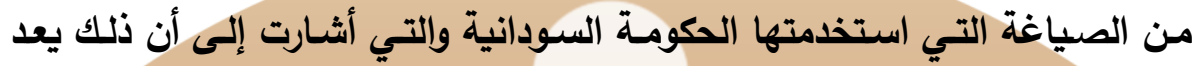

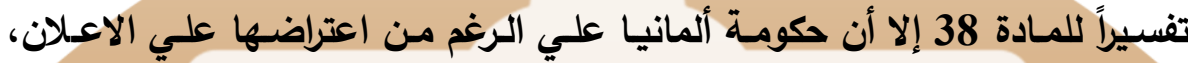

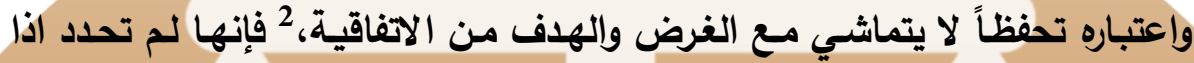
كان التحفظ غير المطابق باطلا وغير نافذ في حقها أم أن هذا الأعتراض يخضع الاضع ل تلمادة 21 من اتفاقية ثيينا.

إن الإعلان السـوداني هو تحفظ مستتر لاتـه باعمـال المعيـار الموضـوعي

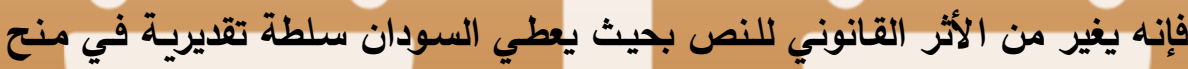

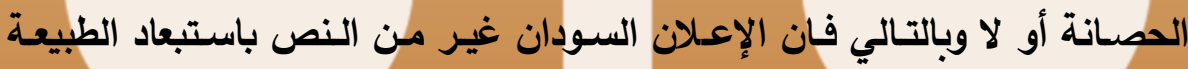

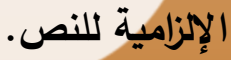

\section{و نشير هنا الي مثال اخر، إذ تنصى المادة 1/11 ملي الآتي:}

"في حالة عدم وجود اتفاق خاص بحجم البعثة الدبلوماسية فيمكن للاولـة

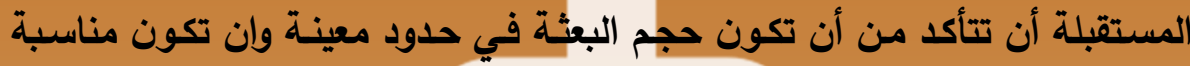

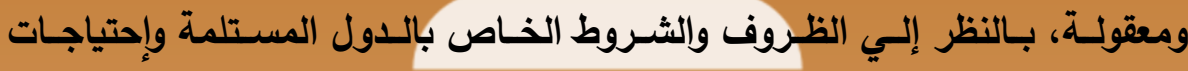

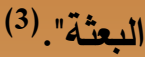

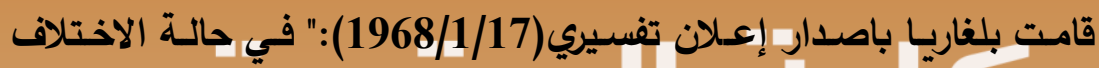

حول حجم البعثة الابلوماسية فيجب الاتفاق بين الدول المرسلة والدول المستقبلة "

(1)United Nations Treaty Collection,

http://treaties.un.org/Pages/ViewDetailsIII.aspx?\&src=TREATY\&mtds g_no=XXI $\sim 6 \&$ chapter $=21 \&$ Temp $=$ tdsg3\&lang $=e n$

(2) United Nations Treaty Collection, http://treaties.un.org/Pages/ViewDetailsIII.aspx?\&src=TREATY\&mtds g no=XXI 6\&chapter $=21 \&$ Temp $=$ mtdsg3\&lang $=$ en

(3) Art. 11 of the Vienna Convention on diplomatic relations. United Nations Treaty Collection, http://treaties.un.org/Pages/ViewDetails.aspx?src=TREATY\&mtdsg_no $=$ =III-3\&chapter $=3 \&$ lang $=$ en 
وفي هذا الاطار قامت كل من بلاروسيا (1964/5/14) ، اليمن (1976/11/24)،

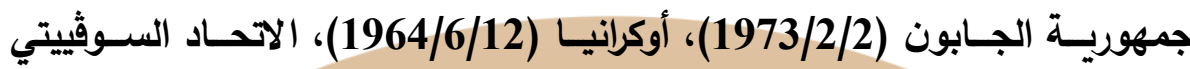

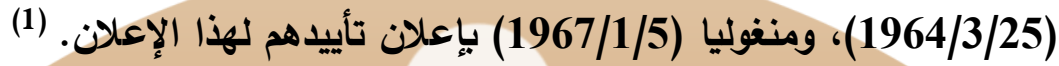

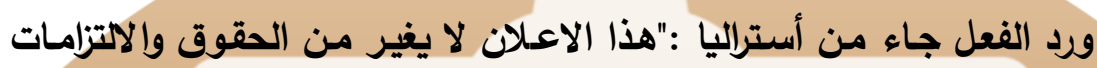

الناشئة عن هذه الفقرة"(2) الفعل جاء

أما بلجيكا فقد اعتبرت الاعلان مخالفا لروح ونص المعاهده وليس من شأنها

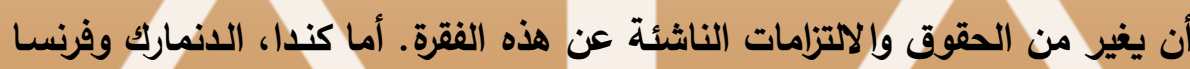

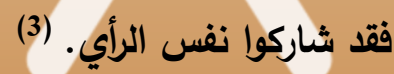

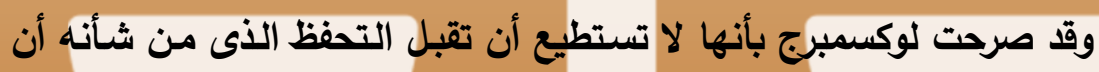

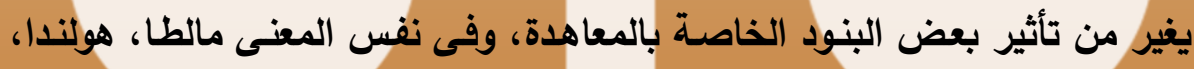

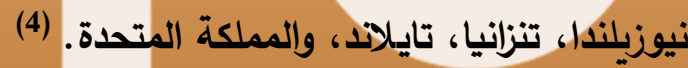

أمـا جمهويـة ألمانيا: فاعتبرت الإعلان مخالفا لروح ونصوص المعاهدة."

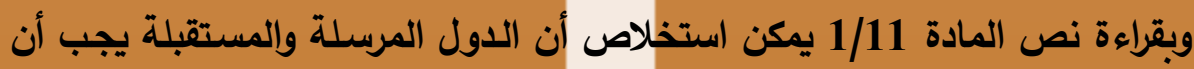

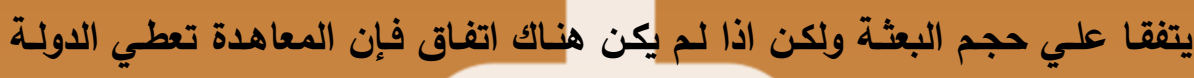

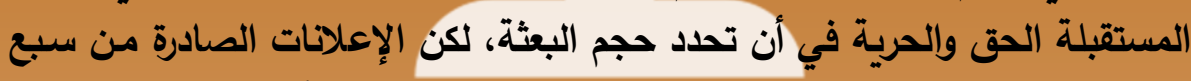

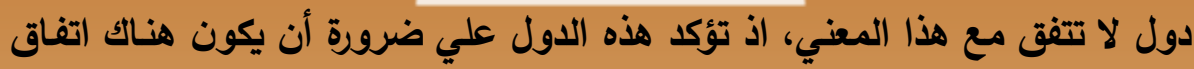
بين الطرفين علي ذلك.

(1)United
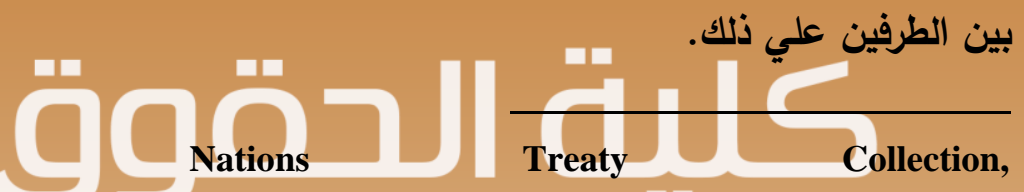
http://treaties.un.org/Pages/ViewDetails.aspx?src=TREATY\&mtdsg_no =III-3\&chapter $=3$ \&lang=en

(2)United Nations http://treaties.un.org/Pages/ViewDetails.aspx?src=TREATY\&mtdsg_no =III-3\&chapter $=3$ \&lang=en

(3)United Nations Treaty Collection, http://treaties.un.org/Pages/ViewDetails.aspx?src=TREATY\&mtdsg_no =III-3\&chapter=3\&lang=en

(4)United Nations Treaty Collection, http://treaties.un.org/Pages/ViewDetails.aspx?src=TREATY\&mtdsg_no =III-3\&chapter $=3$ \&lang $=$ en 
و يبدو أن بعض الدول لم تكن متيقنة عما اذا كان هذا اعلان تفسيريا أو

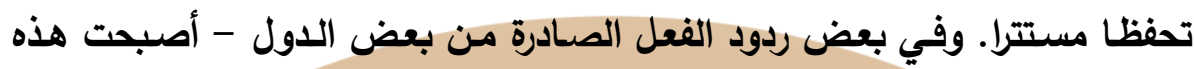

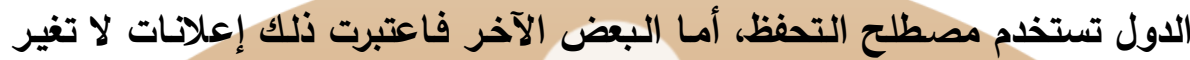

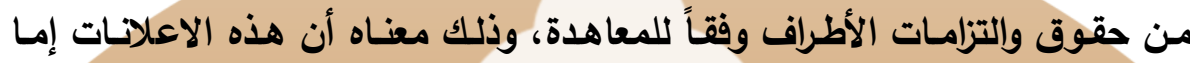

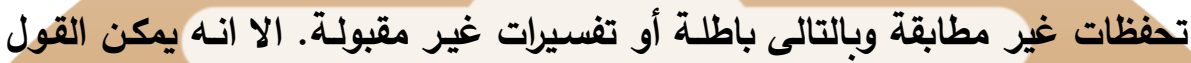

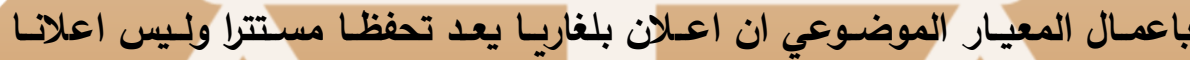

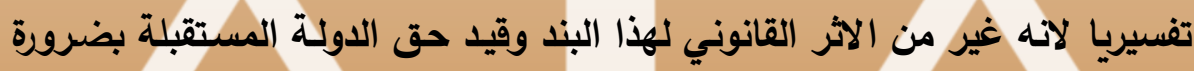

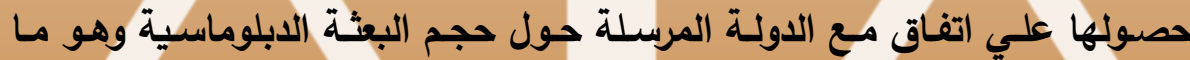
يختلف كلية عن نص المادة الأصلي الذي لا يشترط أي التي اتفاق.

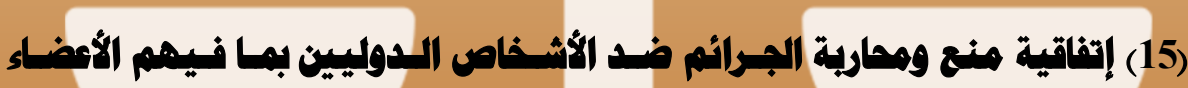
الدبالوماسيين (نيويورك 1973/12/14)

تنص المادة 1/1/ب "- " الأشخاص المحميون دولياً هم :

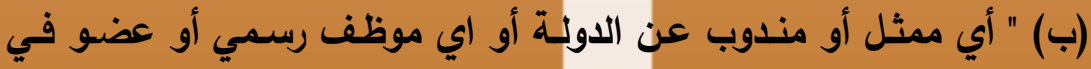

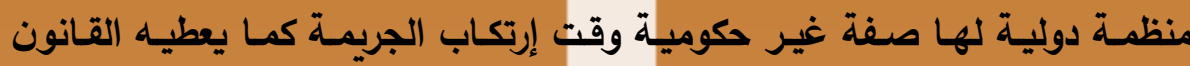

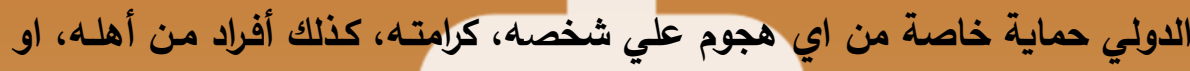

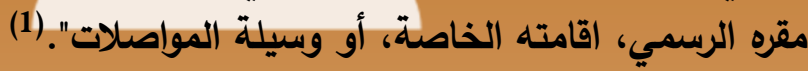
الإعلان الصادر من العراق " (1978/2/28)

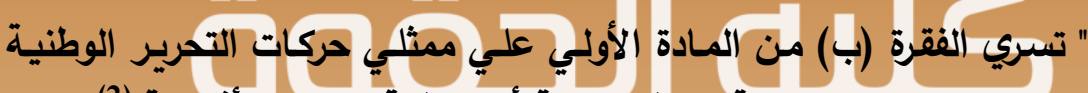

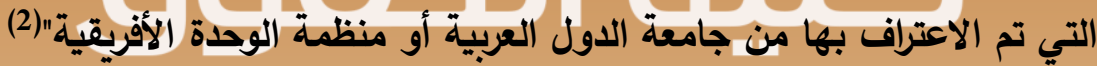
أما رد الفعل من جانب ألمانيا ( 1979/11/30) :- "فان هذا الاعـلان ليس

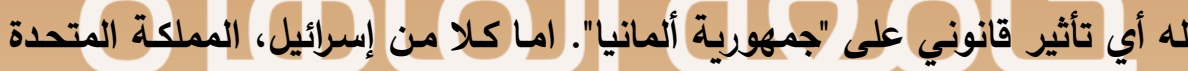

(1) Art. 1 (1)(6) of the Convention on the protection \& punishment of crimes against internationally protected persons including diplomatic agents (New York 14.2.1973).

(2) Convention on the protection \& punishment of crimes against internationally protected persons including diplomatic agents (New York 14.2.1973). 
وايطاليا فقد اعتبروا الاعلان العراقي اعلانا تفسيربا وليس تحفظا.

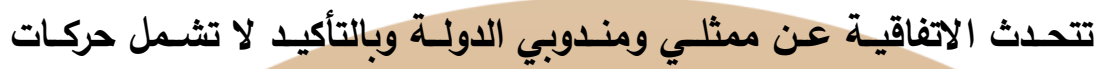

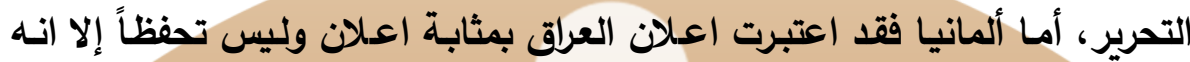

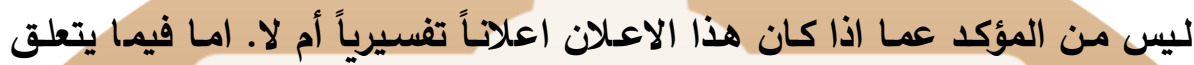

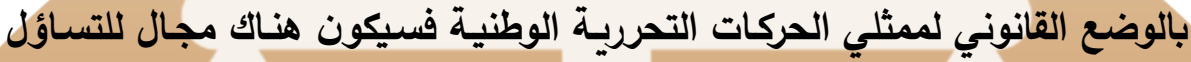

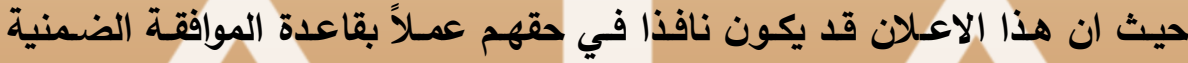
Tacit acceptance

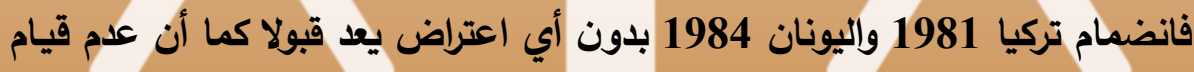

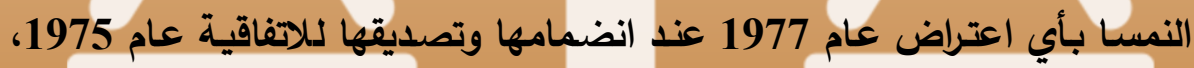

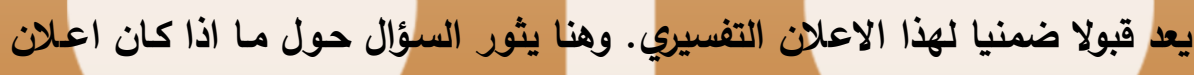

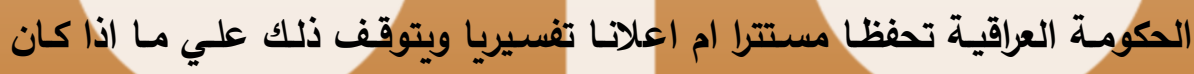

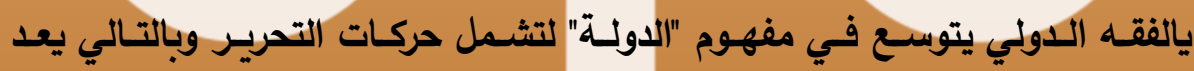

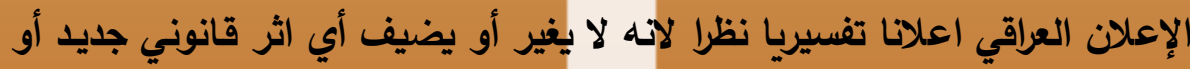

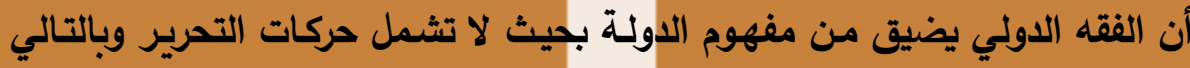

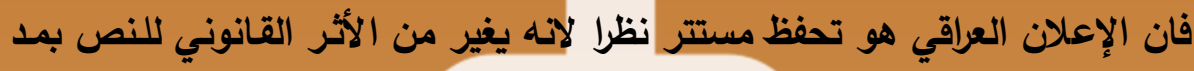
نطاق تطبيقه ليشمل حركات التحرير.

\section{الإبمث الثالث}

\section{التنظيم القانوني الدوفي للتمفظات المسترةة}

إن قواعد القانون الاولي لا تزال قاصرة في مواجهة ممارسـات بعض الدول

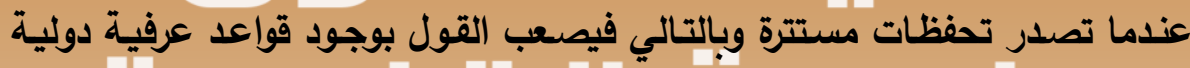

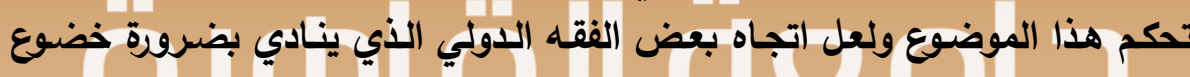

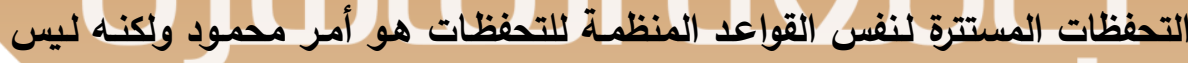

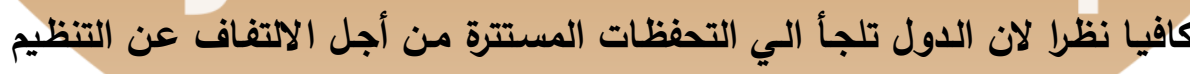

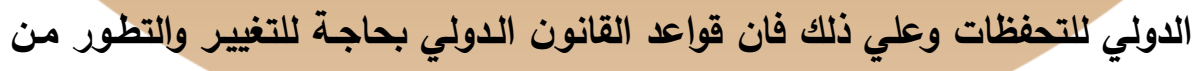

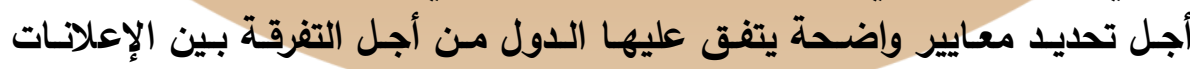

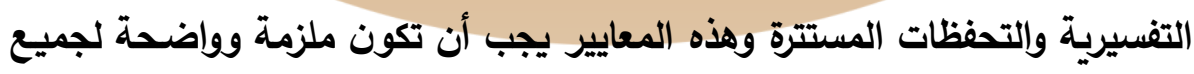




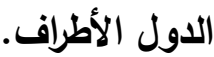

وتبدو الحاجة الي تنظيم دولي للتحفظات المستترة لانها تمثل مشكلة قانونية

في تفسير وتطبيق المعاهدات الدولية فيمـا بين الدول وبالتالي فممارسـات الدول

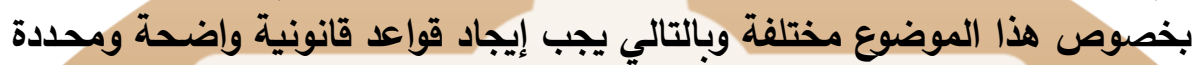

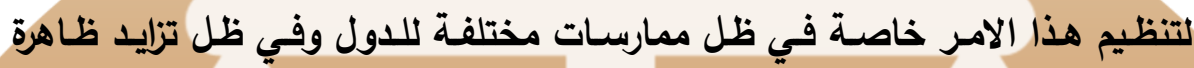
التحفظات المستترة بما يلقي بظلاله علي فاهي فاعلية الاتفاقيات الجماعية. وقد تعدث بعض الفقـه الـدولي حول الإطـار القـانوني لتنظيم التحفظـات

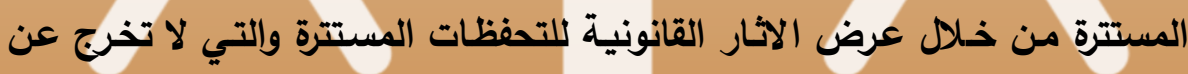
أحد ثلاثة فروض كالاتي:

الفـرض الأول: أن الدولـة التـي تصـدر التــفظ المسـترة لا تعـد طرفـا في

الاتفاقية حيث يبطل التحفظ المستترة قبول الدولة المتحفظة للاتفاقية. الفرض الثاني: ان يتم فصل التحفظ عن قبول الدولة للانضمام الي الاتفاقية

وبالتالي تعد الدولة المتحفظة ملتزمة بكامل الاتفاقية.

الفرض الثالث: استبعاد البنــ اللذي ورد فيـه التحفظ المستترة مـع الإعلان

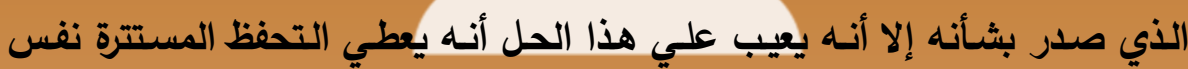
الآثار القانونية للتحفظ الصحيح. 1

وقد أشتار الفقية نيلسون الي أن ممارسة الدول وروح اتفاقيلة قانون البحار

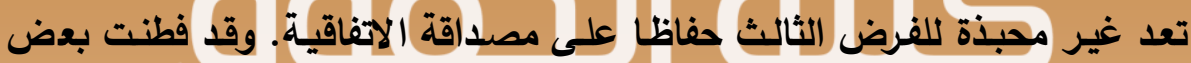

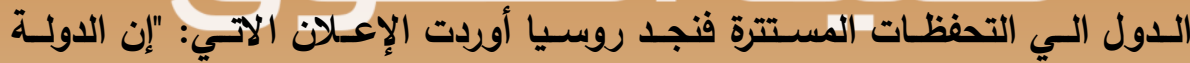

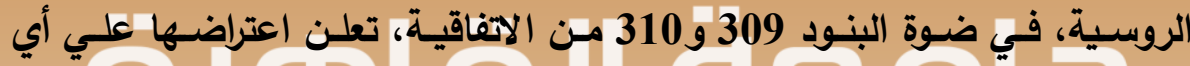

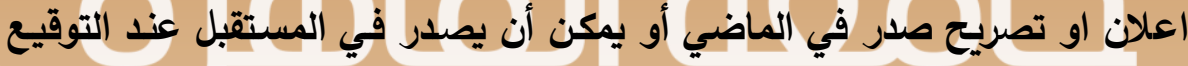

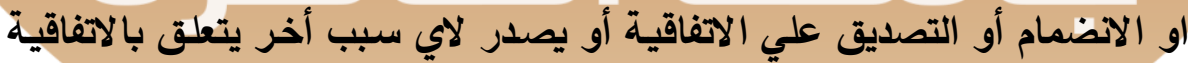

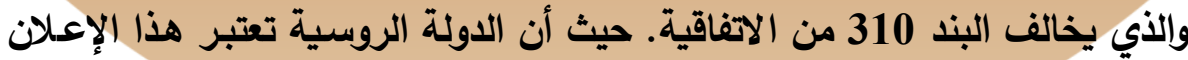

(1) L.D.M. Nelson, Declartions, Statements and Disguised Reservations with respect to the Convention on the Law of the Sea, International and Comparative Law Quarterly, Vol. 50 p. 781. 
أيا كـان تسميته أو صياغته لا يمكن بأي حـال مـن الأحوال أن يغير مـن الآثار

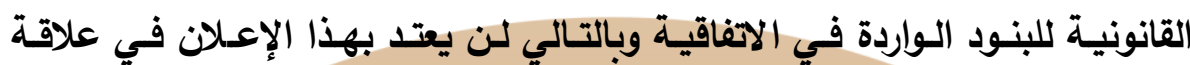
روسيا بالاولة التي أصدرت هذا الإعلان فيما يتعلق بالاتفاقية. 1

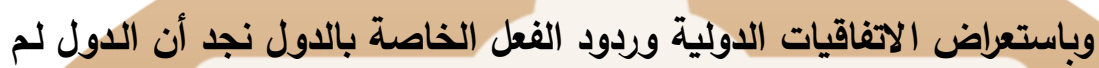

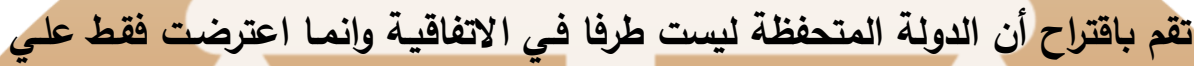

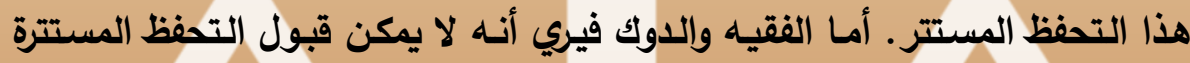
لان نصوص الاتفاقية نفسها في حالية حظر التحفظ قد ألفت إمكانية قبول التهول الدول لاتحفظ.

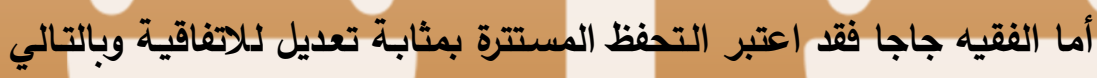

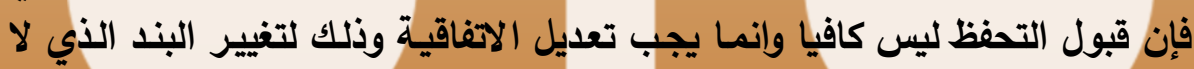
يسمع أو يحظر التحفظ.2

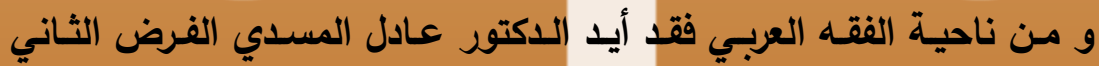

باعتباره متفقا مع نصوص المواد 309 و310 من اتفاقية الأمم المتحدة للبحار. 3 و لقد تناولت الجمعيـة العامـة للأمسم المتحـدة موضسوع التحفظـات المستترة

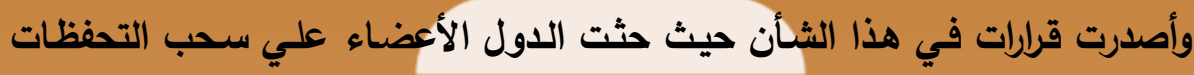

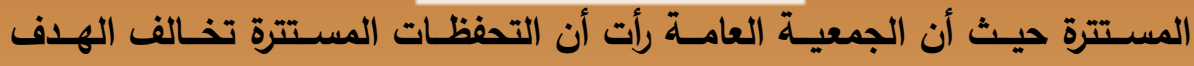
والغرض من الاتفاقية.

(1) L.D.M. Nelson, Declartions, Statements and Disguised Reservations with respect to the Convention on the Law of the Sea, International and Comparative Law Quarterly, Vol. 50 p. 782

(2) L.D.M. Nelson, Declartions, Statements and Disguised Reservations with respect to the Convention on the Law of the Sea, International and Comparative Law Quarterly, Vol. 50 p. 784.

(3) د. عبد الله المسدي، النظام القانوني للاعلانات التفسيرية الصادرة عن الدول بخصوص المعاهدات

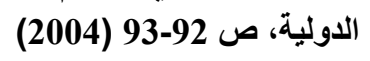


قانونيـة تتعلق بتحديــــــيـف قـانوني للإعـلان وذلـك بـالتطبيق علـي الاتفاقيـة

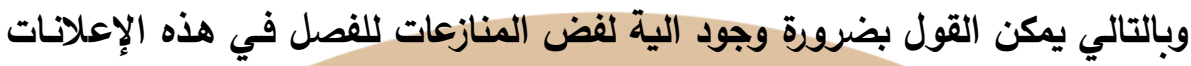

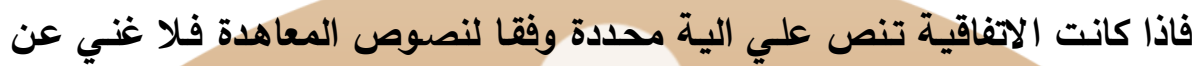

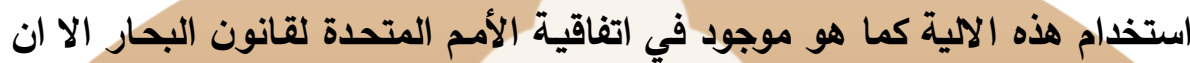

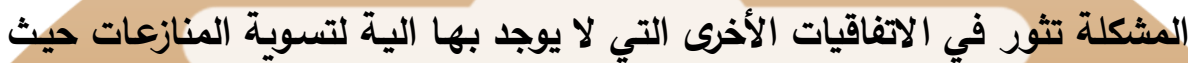

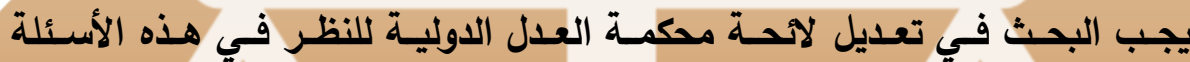
القانونية.

إن تنظيم موضـوع التحفظـات المستترة لا يستلزم وجـود قواعد محددة فقط

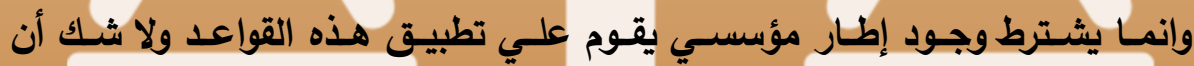

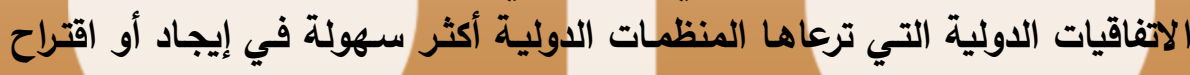
اطار مؤسسي لتفعيل القواعد القانونية المنظمة للتحفظات الماتهات المستترة.

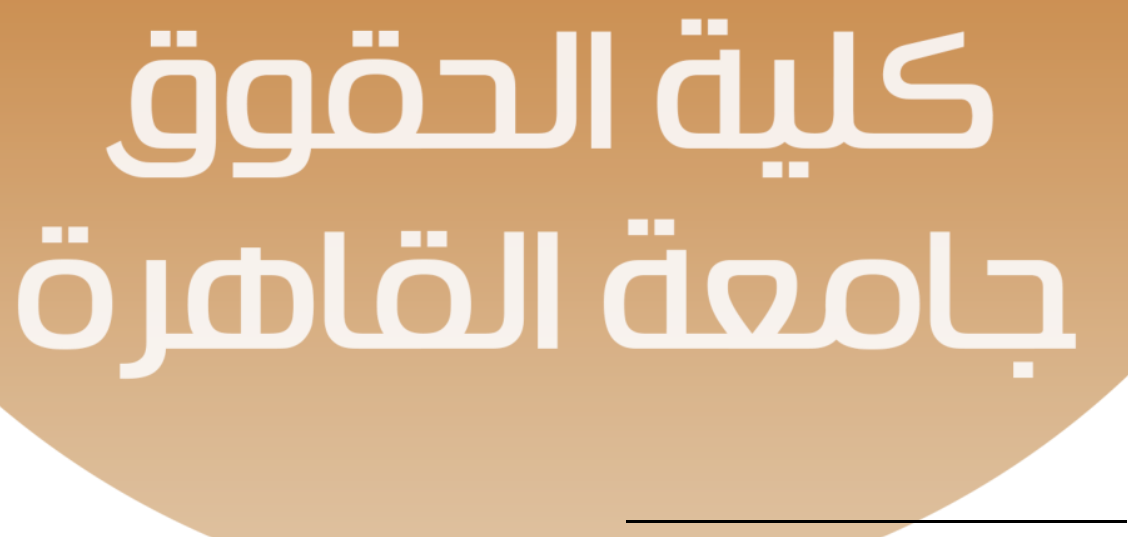

(1) L.D.M. Nelson, Declartions, Statements and Disguised Reservations with respect to the Convention on the Law of the Sea, International and Comparative Law Quarterly, Vol. 50 p. 784-786. 


\section{الغاتمهـــة}

تناول هذا البحث بالدراسـة واحدا من اعقد موضوعات القانون الدولي العام

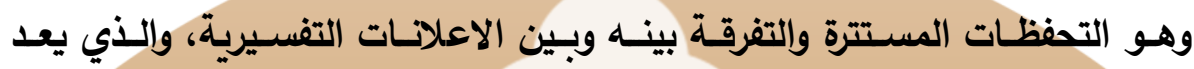

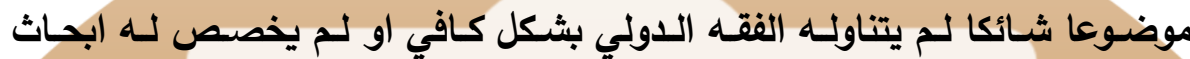
مستقلة من شأنها ان تساعد الدول في تبني موقف محدد تجاه هذا الموضوع. وغني عن البيان ان موضوع التحفظـات المستترة من الموضوعات الحيويـة

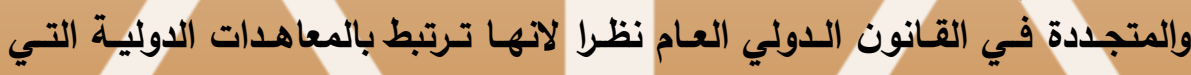

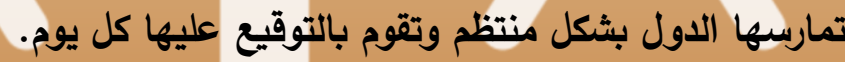

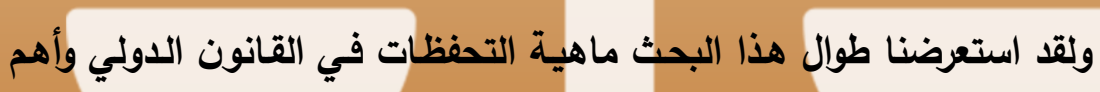

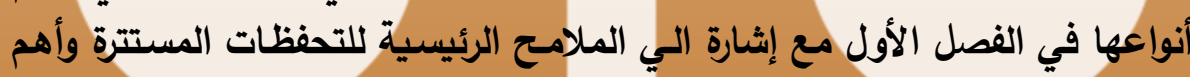

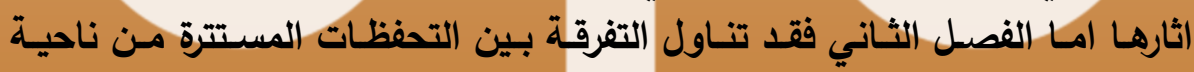

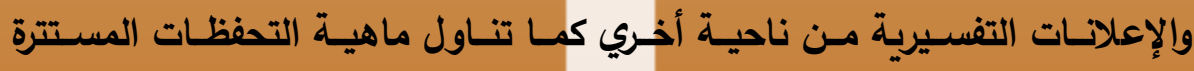

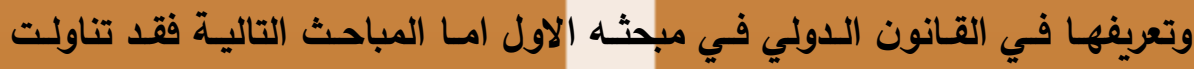

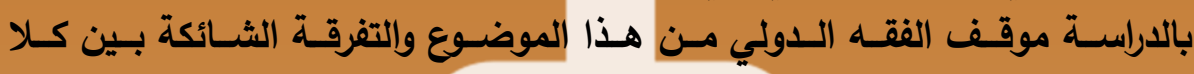

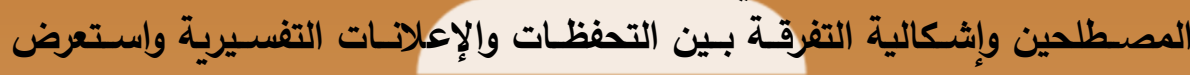

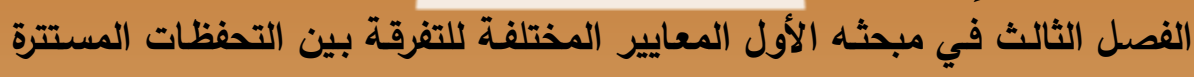

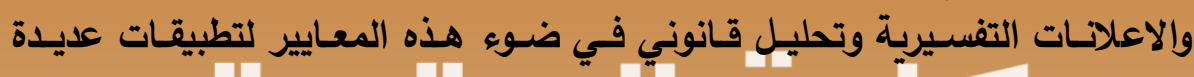

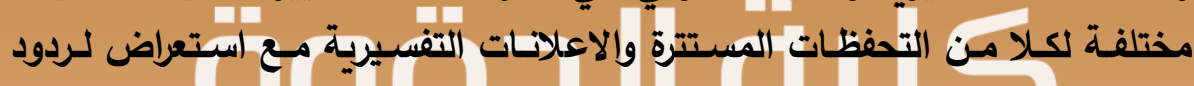

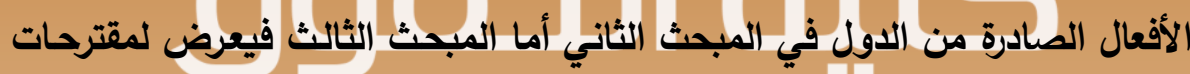
من أجل الوصول الي تنظيم قانوني متكامل للتحفظات المستترة. ويهـف البحث الي تحقيق امرين رئيسيين وهما تعربـف القارئ بالتحفظـات

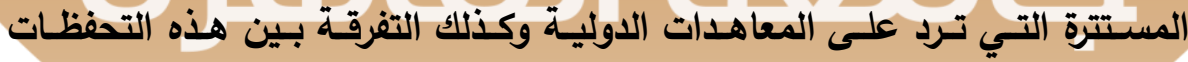

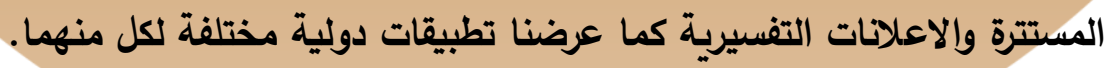
ولا يفوتنا أن نشير الي أن صعوبة دراسة هذا الموضوع تعود بالدرجة الاولي

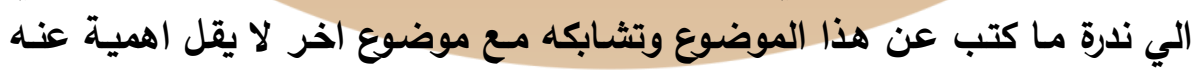

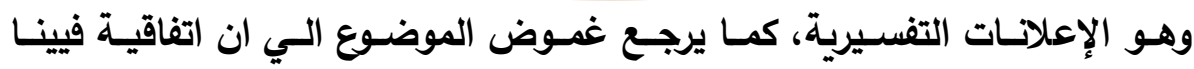


للمعاهدات لعام 1969 لم تتناول او تتعرض من قريب او بعيد للاعلانـات التفسيرية

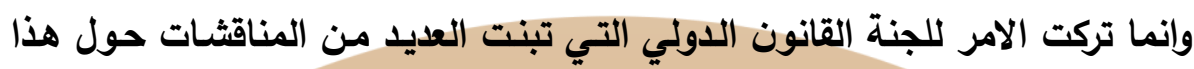

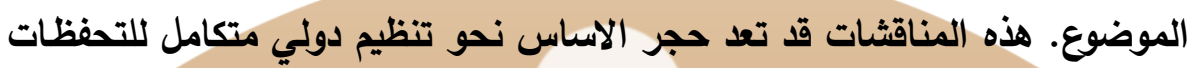
المستترة.

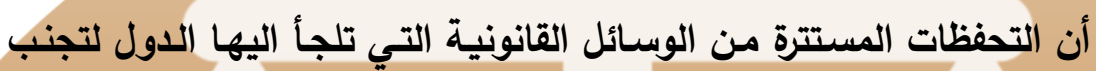

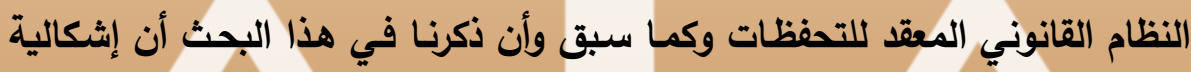

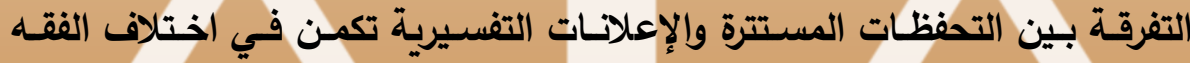

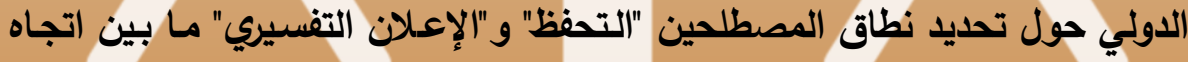

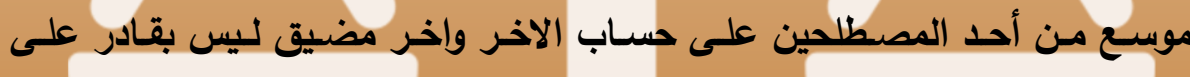
استيعاب التطور المتلاحق لقواعد القانون الدولي. ولحل هذه الإثكالية الهامة يجب البدء في تشكيل قواعد دولية واضحة تنظم

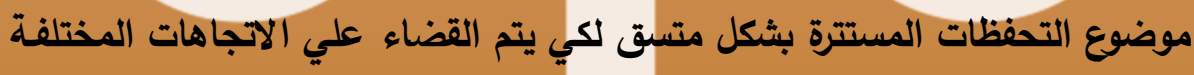

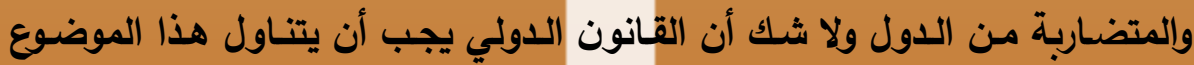
بشكل شامل ويتعرض لكافة الجوانب المتعلقة بهاه.

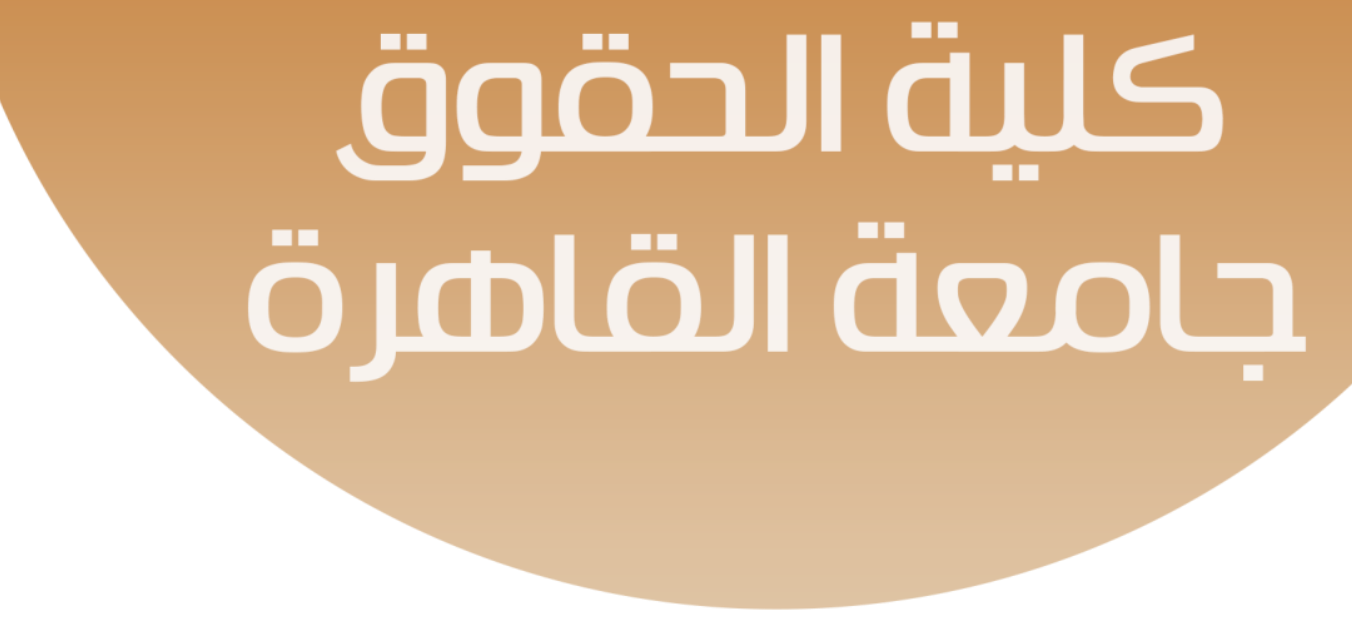




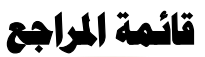

\section{الكتب والمقالات (اللغة العربية)}

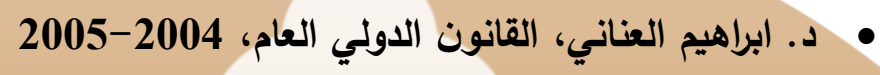

• د. أحمد أبوالوفا، الوسيط في القانون الدولى العام، دار النهضة العربية،

\section{2}

• د. صلاح الدين عامر، مقدمـة لاراسـة القانون الدولي العام،دار النهضـة العربية، دماح الدين عامر 2003.

• د. محمد سامى عبد الحميد، أصول القانون الدولى العام / الجزء الثانى / القاعدة الدولية 2005

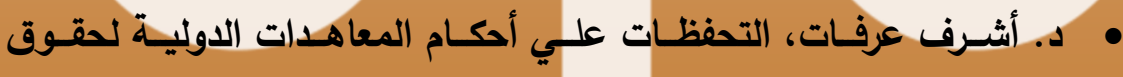

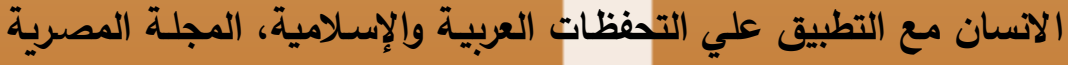
للقانون الدولي، المجلد الثامن والستون، 2012

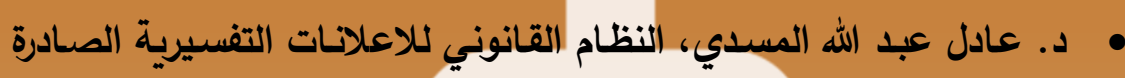
عن الدول بخصوص المعاهدات الدولية، 2004

\section{قائمة المراجع باللمغة الإنجليزية}

Books:

1. Brownlie, Ian, Principles of public international law, clarendon press-Oxford (1998)

2. Davidson, Scott, The law of treaties, Ashgat

3. Gardiner, Richard, Treaty interpretation, Oxford University Press (2008)

4. Holloway, Kaye, Modern trends in treaty law, constitutional law, reservations and the three modes of 
legislation, Stevens \& Sons (London) 1967

5. Horn, Frank, Reservations and interpretative declarations to multilateral treaties, T.M.C. Asser Institut-the hague, the Netherlands (1988)

6. Linderfalk, Ulf, The law of treaties: the modern internarional law as expressed in the 1969 Vienna convention on the law of treaties, Springer, Sweden (2000)

7. Mcnair, Lord, The law of treaties, Clarendon Press, Oxford (1961)

8. Shaw, Malcolm, International law, fifth edition, Cambridge University Press (2004) (UK)

9. Sinclaire, Ian, The Vienna convention on the law of treaties, Manchester University Press

10. Aboul-El-Wafa, Public International Law, Dar AlNahda Al-Arabia, 2008

International Yearbook of International law

The British Yearbook of International Law, 1976-1977

The British Yearbook of International Law, 1978

Reports:

The International Law Commission Report (7 May-5 June 2007) Chapter IV

The International Law Commission Report (1999) 


\section{Articles:}

1) Marjorie Owen, Reservations to multilateral treaties, 38 Yale L.J. 1086 (1928-29)

2) H.W. Malkin, Reservations to multilateral conventions, 7 Brit. Y.B. Int'l L. 141 (1926)

3) L.D. Nelson, Declarations, statements and disguised reservations with respect to the Convention on the law of the Sea, the international law and comparative law quarterly, vol. 50, no. 4 (Oct. 2001), p. 767-786

4) Richard W. Edwards, Reservations to treaties, 10 Mich. J.Int'l L. 362 (1989)

5) D.W. Bowett, Reservations to non-restricted multilateral treaties, 48 Brit. V.B. Int'l L. (1976-77)

6) D.M. McRae, The legal effect of interpretative declarations, 49 Brit. Y.B. Int'L. L. (1979)

7) Yingliang Huang, Reservations to multilateral human rights treaties, LL.M. thesis-faculty of Graduate and postdoctoral studies, university of Ottawa.

8) Pierre-Henri Imbert, Reservations to the European convention on human rights before the Strasbourg commission: The temeltaschae case, 33 Int'l \& Comp. L.Q. 558 (1984)

9) John king Gamble, Reservations to multilateral treaties: A macroscopic view of state practice, 74 Am. J. Int'l L. 372 (1980) 
10) Henry Bourguignon, The belilos case: new light on reservations to multilateral treaties, 29 Va. J. Int;l L. 347 (1988-89)

11) Madeline Morris, Few reservations about reservations, 1 Chi. J. Int'l. L. 341 (2000)

12) D.R. Anderson, Reservations to multilateral conventions, a reexamination, 13 Int'l \& Comp. L.Q. 450 (1964)

13) Francesco Parrisi \& Catherine Sevenko, Treaty reservations and the Economics of Article 21 (1) of the Vienna convention, 21 Berkeley J. Int'l L. 1 (2003)

14) Lawrence R. Hefler, Not fully committed? Reservations, risks, and treaty design, 31 Yale J. Int'l L. 367 (2006)

15) Jean Kyongun Koh, Reservations to multilateral treaties: how international legal doctrine reflects world vision, 23 Harv. Int'L. L. J. 71 (1982-83)

16) Edward Swaine, Reserving, 31 Yale J. Int'l L. 307 (2006)

17) Daniel Hylton, Default breakdown: the Vienna convention on the law of treaties' inadequate framework on reservations, 27 Vand. J. Transnat'l L. 419 (1994)

18) Belinda Clark, The Vienna convention reservations regime and the convention on discrimination against women, 85 Am. J. Int'l L. 281 (1991)

19) G.C. Fitzmaurice, Reservations to multilateral conventions, 2 Int'l \& Comp. L.Q. 1 (1953)

20) Rebecca J. Cook, Reservations to the convention on the 
elimination of all forms of discrimination against women, 30 Va. J. Int'l L. 643 (1989-90)

Andres' E. Montalvo, Reservations to the American convention on human rights: a new approach, $16 \mathrm{Am}$. U. Int' 1L. Rev. 269 (2000-01)

21) M. Fitzmaurice, On the protection of human rights, the Rome statute and reservations to multilateral treaties, 10 S.Y.B.I.L. 133

22) Konstantin Korkelia, New challenges to the regime of reservations under the international covenant on civil and political rights, 13 Eur. J. Int'l L. 437

23) George K. Walker, Professional's definitions and state's interpretative declarations (understandings, statements, or declarations) for the 1982 law of the Sea convention, 21 Emory Int'l L. Rev. 461

24) Palitha T.B. Kohona, Some notable developments in the practice of the UN secretary-general as depository of multilateral treaties: reservations \& declarations, $99 \mathrm{Am}$. J. Int'l L. 433

25) Dwight G. Newmann, The Rome statute, some reservations concerning amnesties, and a distributive problem, 20 Am. U. Int'l L. Rev. 293

26) Andres' E. Montalvo, Reservations to the American Convention on human rights: a new approach, $16 \mathrm{Am}$. U. Int'l L. Rev. 269 
مجلة القانون والاقتصاد - ملحق العدد (الثانى والتسعون)

\section{Recueil des cours:}

William W. Bishop, Reservations to treaties, 103 Tome 103 de la collection Recueil des cours 245 (1961)

J.M. Ruda, Reservations to treaties, Tome 146 de la collection Recueil des cours 195 (1975)
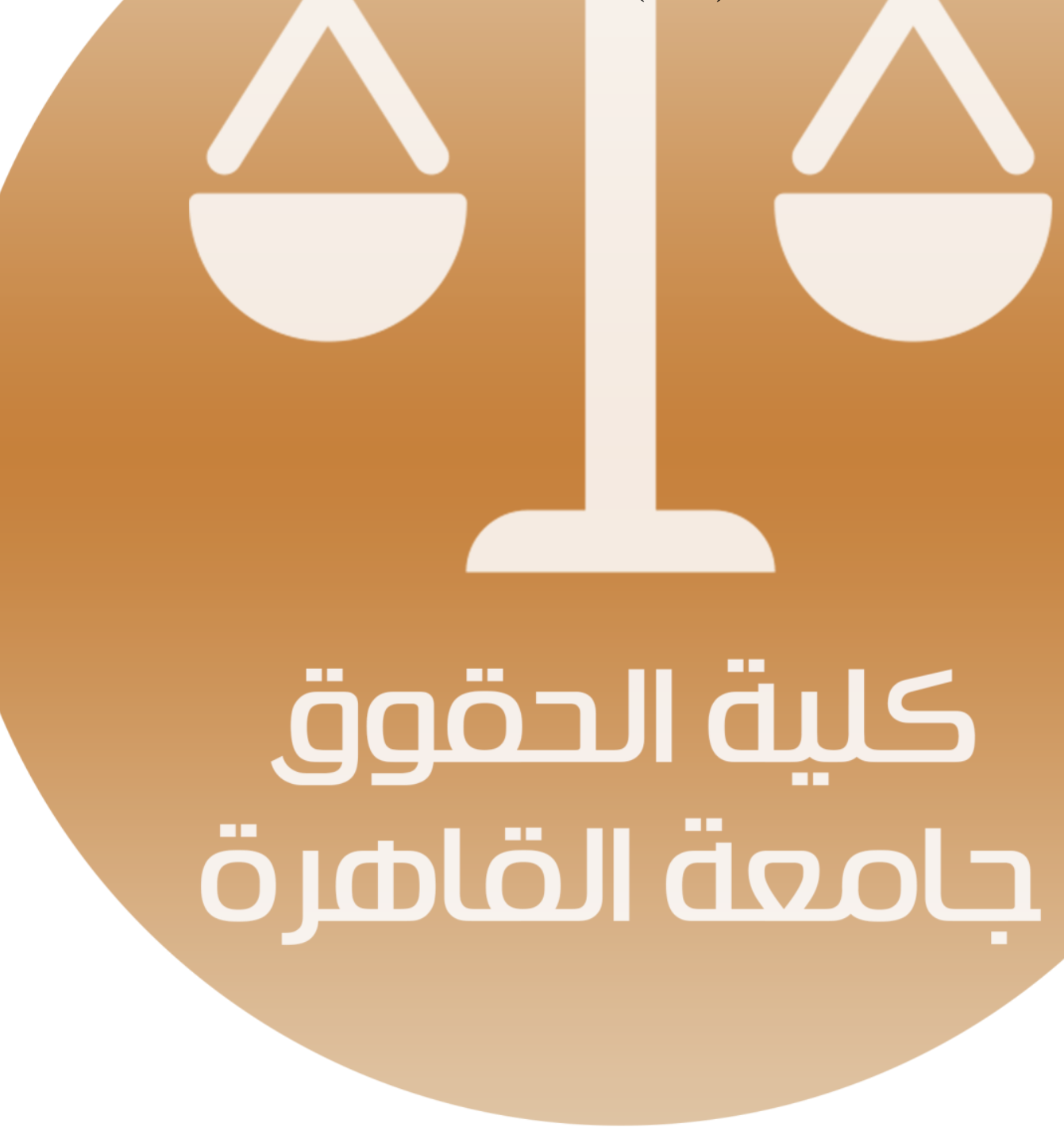